\title{
Avaliação genômica da infertilidade masculina idiopática por azoospermia não obstrutiva
}

Tese de Doutorado apresentada ao Programa de pós-graduação da Faculdade de Medicina de Ribeirão Preto da Universidade de São Paulo, como parte dos pré-requisitos para obtenção do título de Doutor em Ciências

Área de Concentração: Genética

Orientadora: Profa. Dra. Lucia R. Martelli

Ribeirão Preto 
Autorizo a reprodução e divulgação total ou parcial deste trabalho, por qualquer meio convencional ou eletrônico, para fins de estudo e pesquisa, desde que citada a fonte.

\section{FICHA CATALOGRÁFICA}

Grangeiro, Carlos Henrique Paiva

Avaliação genômica da infertilidade masculina idiopática por azoospermia não obstrutiva. Ribeirão Preto, São Paulo, 2018.

176p. : il. ; $30 \mathrm{~cm}$

Tese de doutorado apresentada à Faculdade de Medicina de Ribeirão Preto / USP. Área da concentração: Genética.

Orientadora: Martelli, Lúcia.

1. Infertilidade masculina. 2. Azoospermia 3. Hibridação genômica comparativa. 4. Variante de número de cópias (CNV). 5. Regiões de perda de heterozigosidade (LOH 


\section{APOIO E INSTITUCIONAL E SUPORTE FINANCEIRO}

Este trabalho foi realizado com apoio e suporte financeiro das seguintes instituições:

1) Programa de Excelência Acadêmica (PROEX) da Coordenação de Aperfeiçoamento de Pessoal de Nível Superior (CAPES) - Processo: $1414115 / 2014$

2) Fundação de Apoio ao Ensino, Pesquisa e Assistência do Hospital das Clínicas da Faculdade de Medicina de Ribeirão Preto da Universidade de São Paulo (FAEPA)

3) Hospital das Clínicas da Faculdade de Medicina de Ribeirão Preto da Universidade de São Paulo (HCFMRP)

4) Departamento de Genética da Faculdade de Medicina de Ribeirão Preto da Universidade de São Paulo 


\section{FOLHA DE APROVAÇÃO}

Nome: GRANGEIRO, Carlos Henrique Paiva

Título: Avaliação genômica da infertilidade masculina idiopática por azoospermia não obstrutiva.

Tese apresentada ao Programa de Pós-graduação da Faculdade de Medicina de Ribeirão Preto da Universidade de São Paulo, como parte dos prérequisitos para obtenção do título de Doutor em Ciências

Área de Concentração: Genética

Aprovado em:

\section{Banca Examinadora}

Prof. Dr.

Intistuição:

Assinatura:

Prof. Dr.

Intistuição:

Assinatura:

Prof. Dr.

Intistuição:

Assinatura

Prof. Dr.

Intistuição:

Assinatura:

Prof. Dr

Intistuição:

Assinatura: 


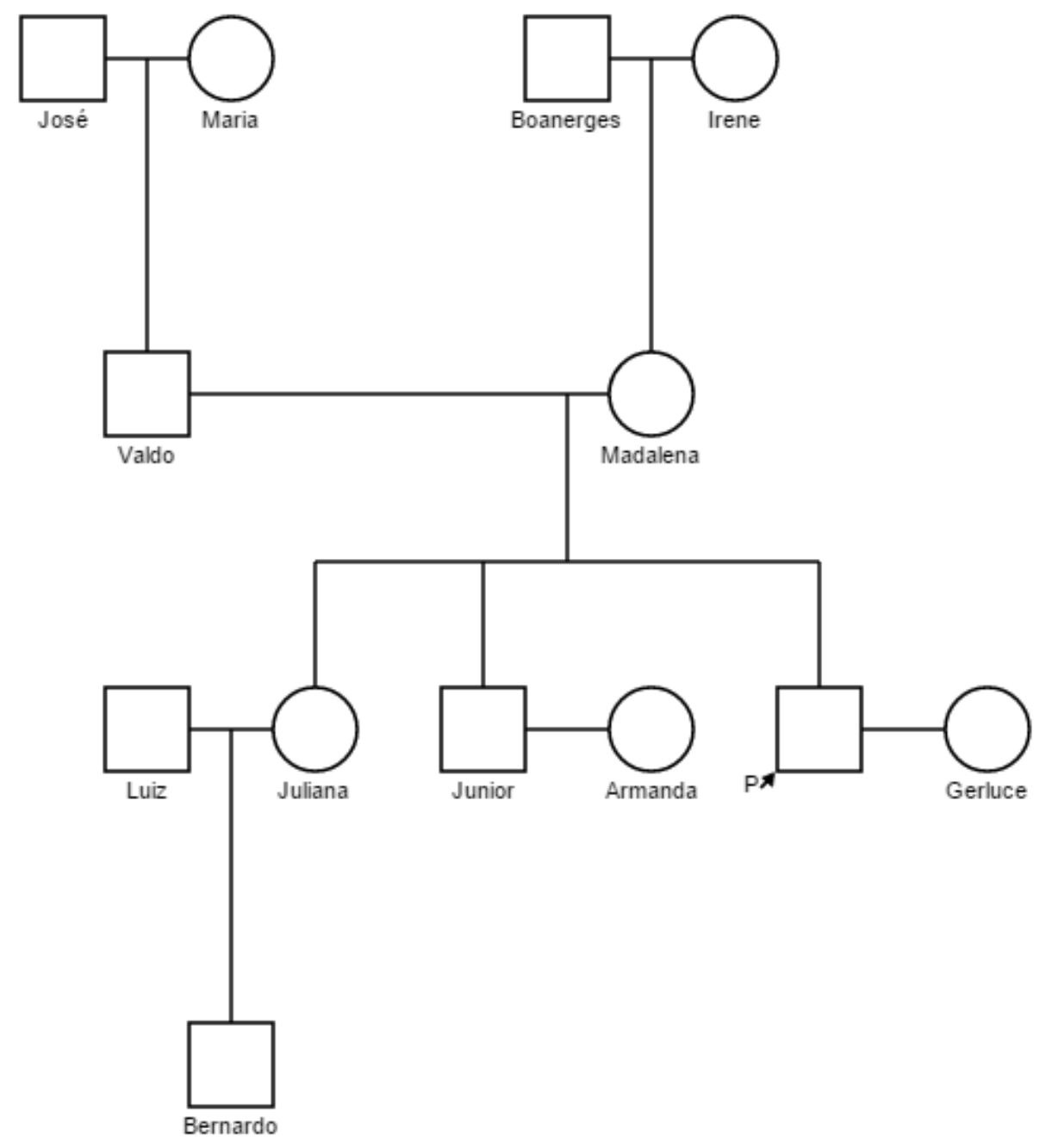

A minha FAMÍLIA 
"Eu confesso que a genética é um assunto que me fascina porque suas leis, que também são azares, formulam-se à base de um grande e poético mistério.”

Vinícius de Moraes

Saudade dentro do peito

É qual fogo de monturo

Por fora tudo perfeito,

Por dentro fazendo furo.

Há dor que mata a pessoa

Sem dó e sem piedade,

Porém não há dor que doa

Como a dor de uma saudade.

Saudade é um aperreio

Pra quem na vida gozou,

É um grande saco cheio

Daquilo que já passou.

Saudade é canto magoado

No coração de quem sente

É como a voz do passado

Ecoando no presente.

\section{Patativa do Assaré}

“Em geral, não são nossas ideias que nos fazem otimistas ou pessimistas, mas é o nosso otimismo ou pessimismo que faz nossas ideias". 


\section{AGRADECIMENTOS}

São duas as palavras que ajudam a expressar os meus agradecimentos: obrigado e gratidão. Obrigado, deriva do latim obligatus e significa manter-se ligado (elo) às pessoas como débito por terem prestado um favor ou auxílio ("fico obrigado a você" ou "fico devendo obrigação a você). Gratidão, deriva do latim gratia, que significa estima por tudo que recebi de uma determinada pessoa. Nesse sentido, mesmo com todos os elos, tenho mais gratia que obligatus.

A todos os pacientes que aceitaram participar dessa pesquisa, mesmo sabendo que os possíveis resultados podiam não trazer respostas às suas dúvidas ou trazer benefício direto, mas que poderiam contribuir para sanar dúvidas dos outros. Foram momentos de intenso aprendizado não só científico, mas também humano.

À Dra. Lucia Martelli, minha orientadora, que me acolheu e quem sempre me estimulou. Tornou-se referência não só profissional, mas também humana. Sou imensamente grato por sua confiança, seus ensinamentos que muitas vezes vinham com um leve puxão de orelha ("isso deve ser coisa do Carlos...") e, o mais importante, sua amizade.

Ao Dr. Jeremy Squire, pelas sugestões sempre pertinentes, fomento na compra das lâminas de hibridação genômica e colaboração atenta na realização desse projeto. Tinha até esperança de associar o PTEN ao trabalho, para estimulá-lo ainda mais nas discussões. Meu muito obrigado!

À banca examinadora pela disposição e contribuição para o crescimento deste trabalho.

Ao “Trio Fantástico” (Dra. Juliana Dourado, MSc. Tatiana Mozer, À Dra. Flávia Gaona) que com suas diferentes expertises, contribuíram intensamente em diferentes etapas desse projeto.

À Dra. Juliana Dourado, pela parceria na investigação genômica de pacientes inférteis com oligozoospermia e na realização de parte da investigação molecular.

À MSc. Tatiana Mozer, a Tati, a nossa CITOGENOMICISTA, meu muito obrigado por sua amizade e companheirismo. Guardo com muito carinho a sua parceria constante, seja 
na bancada nos fins de semana ou às vezes à noite, nas saídas etílicas ou "glutônicas" e é claro, seu suporte técnico de excelência.

À Dra. Flávia Gaona, a Flavinha, pela amizade e parceria na realização da técnica de Hibridação Genômica Comparativa. Sei que você sofreu junto com aquelas duas "bolas amarelas" que apareceram no primeiro experimento...

Aos amigos do Bloco C e Laboratório de Citogenética Molecular Humana (Alexandra, Thiago, Clarissa, Lívia, Silvio e Victoria) pela parceria, discussões dos dados preliminares e vários momentos de alegria.

Ao Serviço de Genética Médica do Hospital das Clínicas de Ribeirão Preto, minha segunda casa, onde concluí minha especialidade e que permitiu a realização desse projeto. Agradeço a todos os docentes (Dra. Lúcia Martelli, Dr. Pina, Dra. Ester Ramos e Dr. Victor Ferraz), assistentes (Jair, Lisandra e Wagner) e colegas de residência (Ricardo, Dani, Clarissa, Lucía, Ju, Ana, Sue, Paolita, Rayana, Thereza e Deivid) pela amizade e aprendizado. Um agradecimento especial à Fátima Carvalho, que sempre cuidou muito bem de mim e dos nossos pacientes. Obrigado por aquele abraço, beijo e risadas antes de começar os ambulatórios. Muito obrigado Fatinha! Nossa formação como especialistas também passa pela sala 19 do corredor 9 dos Ambulatórios do Hospital das Clínicas de Ribeirão Preto.

Aos biologistas do Laboratório de Citogenética do Hospital das Clínicas de Ribeirão Preto (Rinaldo e Sarah) e, em especial, à Lucimar Aparecida Fernandes Laureano que sempre me "acudiu" quando eu vinha com mais um tubo verde inesperado. Nunca irei esquecer do ramal 2743 e logo após: “Chefa, posso coletar amostra agora?"

Ao Laboratório de Imunogenética Molecular da Faculdade de Medicina de Ribeirão Preto, em especial ao Prof. Dr. Geraldo Aleixo Passos Júnior que permitiu utilização de parte dos equipamentos para a realização da técnica de Hibridação genômica e, em especial, à Dr. Amanda Freira Assis Riccardi e ao mestrando Max Jordan de Souza Duarte que nos auxiliaram na realização, extração e análise dos resultados de array.

Aos funcionários do Departamento de Genética da Faculdade de Medicina de Ribeirão Preto, em especial à Susie, que sempre ajudou nesse percurso complexo da pósgraduação. Susie, meu muito obrigado. Sentirei saudades. 
Ao Prof. Dr. Carlos Molina e a todos os contratados e residentes do ambulatório de infertilidade do Hospital das Clínicas de Ribeirão Preto pelo encaminhamento dos pacientes e por acreditarem que a investigação genético-clínica é importante na avaliação dos seus pacientes.

À Dra. Juliana Meola, ao Dr. Jair Huber e novamente ao Dr. Carlos Molina pela discussão e sugestões durante a banca de qualificação.

À MSc. Ana Carina Fernandes Ometto Schineider, minha primeira professora de Genética, no curso de Ciências Biológicas; à Profa. Dra. Sílvia Helena Barem Rabenhorst, minha professora de Genética na Faculdade de Medicina e orientadora de iniciação científica (me aturou por 5 anos da graduação, sendo 4 anos na monitoria da disciplina de Genética e mais 2 anos na iniciação científica) e mais uma vez à Profa. Dra. Lucia Martelli, que me orientou nos cursos de pós-graduação (Residência Médica e Doutorado), nesses 7 anos de vida ribeirãopretana. Obrigado por terem contribuído com a minha formação e manterem o fascínio pela Genética.

À Coordenação de Aperfeiçoamento de Pessoal de Nível Superior (CAPES) e à Fundação de Apoio ao Ensino, Pesquisa e Assistência do Hospital das Clínicas da Faculdade de Medicina de Ribeirão Preto (FAEPA) pelo apoio financeiro.

Aos amigos que também participaram dessa empreitada. Os que estão distantes, em Fortaleza, os que me receberam em Ribeirão Preto (Mona/Leudo), os que me aceitaram na família que formamos no "por trás da Fiúsa" (Belise Kmentt e Felipe Mavignier) e os que foram aparecendo e que fui adentrando em suas casas (Ju Josahkian, Ricardo, Tati e Simone).

A Deus e a minha família por darem o significado a minha vida. Em especial aos meus pais Valdo e Madalena, que sofreram bastante com a minha vinda para Ribeirão, mas que com o tempo, compreenderam que a felicidade do seu filho também dependia desses passos fora de casa. À Ju e ao Júnior, meus irmãos, que sempre confiaram e apoiaram seu irmão caçula. Amo vocês! Ao bebê Bernardo (Dedé), que tem reavivado o amor na nossa família e propiciado muitos momentos de risos fáceis com as suas peripécias. Ao Luiz e à Armanda, que decidiram por fazer parte da família e por fim, e em especial, a minha namorada, noiva, companheira e, finalmente, esposa Gerluce Lourenço. Obrigado pelo seu amor e companheirismo. Te amo. 


\section{RESUMO}

GRANGEIRO, C. H. P. Avaliação genômica da infertilidade masculina idiopática por azoospermia não obstrutiva [tese]. Ribeirão Preto: Universidade de São Paulo, Faculdade de Medicina de Ribeirão Preto; 2018; 176 páginas

Infertilidade conjugal é uma doença do sistema reprodutivo que acomete cerca de $20 \%$ dos casais e na qual o fator masculino responde por metade desses casos. A infertilidade masculina é um fenótipo complexo que abrange diferentes fatores. Os fatores genéticos envolvidos variam desde mutações pontuais, microdeleções no cromossomo Y, até alterações cromossômicas, como a Síndrome de Klinefelter. Mesmo após avaliação clínicolaboratorial detalhada, metade dos pacientes permanece sem a identificação de um fator causal, caracterizando a infertilidade idiopática. Nesse grupo, observamos com maior frequência os pacientes com falha espermatogênica primária, que clinicamente apresentam oligozoospermia grave ou azoospermia não obstrutiva (ANO) e, no qual, preponderam fatores genéticos ainda desconhecidos. Para auxiliar na compreensão de possíveis alterações genômicas, sejam as variantes de número de cópias (CNVs) ou as regiões de perda de heterozigosidade (LOHs), envolvidas com infertilidade masculina idiopática, 16 pacientes com ANO e 6 controles foram investigados pela técnica de hibridação genômica comparativa (aCGH) utilizando a plataforma 4x180 CGH+SNP Agilent ${ }^{\circledR}$ com análise dos dados pelo software Nexus 8.0. Não foram observadas diferenças significativas tanto no número, como no tamanho das alterações genômicas em ambos os grupos. Foram descritas 18 novas alterações genômicas com efeito sobre a produção espermática, distribuídas na forma de 12 ganhos, 3 perdas e 3 LOHs. Os ganhos mais significativos para o fenótipo azoospermia não obstrutiva foram descritos em 7q36.3, 17q21.33, Xq21.1 e Yp11.2. Nessas regiões, os genes com maior impacto sobre o fenótipo foram, respectivamente, $\mathrm{SHH}$, COL1A1, COX7B e LINC00279. Ganhos envolvendo a sub-banda Yq11.223 e contendo cópias dos genes $D A Z 1$ e DAZ4 foram considerados benignos. As três perdas detectadas em 2q31.1, 3p21.1-21.31 e 15q11.2, contendo, respectivamente, os genes DLX1, CACNA2D2 e representantes da família de receptores olfatórios foram consideradas relevantes. A análise das LOHs em fenótipos complexos é escassa e desafiadora. No presente trabalho, foram descritas 3 dessas alterações, localizadas em 1p31.1, 7q21.1 e 12q21.1-21.2 e compartilhadas por mais de um indivíduo infértil. A descrição dessas alterações genômicas contribui para a compreensão de mecanismos complexos e ainda pouco estudados, que resultam em azoospermia não obstrutiva decorrente da falha espermatogênica primária.

Palavras-chave: Infertilidade masculina. Azoospermia. Hibridação genômica comparativa. Variante de número de cópias (CNV). Regiões de perda de heterozigosidade (LOH). 


\begin{abstract}
GRANGEIRO, C. H. P. Genomic assessment of idiopathic male infertility by nonobstructive azoospermia [thesis]. Ribeirão Preto: University of São Paulo, Ribeirão Preto Medical School; 2018;
\end{abstract}

Infertility is a disease of the reproductive system that affects about $20 \%$ of all couples, with half of the cases being related to the male factor. Male infertility is a complex phenotype associated with an interaction of different factors. The genetic factors involved may range from point mutations, microdeletions on the $\mathrm{Y}$ chromosome to chromosomal changes such as Klinefelter syndrome. Even after detailed clinical-laboratory evaluation, the etiology may remain unknown in approximately half of the patients, and, in such cases, the infertility can be classified as idiopathic. This group of patients more frequently present with primary spermatogenic failure, with severe oligozoospermia or non-obstructive azoospermia (NOA). Nevertheless, the underlying genetic factors are still largely unknown. In order to better understand the potential genomic changes involved with idiopathic male infertility, sixteen patients with NOA and 6 controls were investigated in this study. Copy number variants (CNVs) and regions of loss of heterozygosity (LOHs) were assessed by array comparative genomic hybridization technique $(\mathrm{aCGH})$, using the Agilent ${ }^{\circledR} 4 \times 180 \mathrm{CGH}+\mathrm{SNP}$ platform. Data analyses was performed using Nexus 8.0 software. No significant differences between the groups were observed in relation to either the number or the size of the genomic changes. Eighteen new genomic alterations were described that were associated with sperm production (12 gains, 3 losses and 3 LOHs). The most important gains for the nonobstructive azoospermia phenotype were observed in 7q36.3, 17q21.33, Xq21.1 and Yp11.2. In these regions, the genes related to greatest impact on the phenotype were SHH, COL1A1, COX7B and LINC00279, respectively. Gains involving the Yq11.223 sub-band and containing copies of the DAZ1 and DAZ4 genes were considered benign. All 3 losses detected in 2q31.1, 3p21.1-21.31 and 15q11.2, containing, respectively, the DLX1, CACNA2D2 genes and representatives of the olfactory receptor family were considered relevant. Analysis of LOHs in complex phenotypes such as male infertility has been infrequently reported and is challenging. In the present study, three significants LOHs were found (1p31.1, 7q21.1 and 12q21.1-21.2) and were identified in more than one infertile individual. The description of these genomic alterations contributes to a better understanding of this complex and poorly explored mechanisms that results in non-obstructive azoospermia due to primary spermatogenic failure.

Keywords: Male infertility. Azoospermia. Comparative genomic hybridization. Copy Number Variation (CNV). Loss of Heterozygosity (LOH). 


\section{LISTA DE FIGURAS}

Figura 1 - Representação da distribuição global dos casos de infertilidade devido ao fator masculino. .23

Figura 2 - Eixo Hipotálamo-Hipófise-Testículo

Figura 3 - Representação do corte sagital mediano da pelve e períneo masculino (A) e da visão posterior do sistema de transporte dos espermatozoides (B). .29

Figura 4 - Relação entre a concentração espermática e a prevalência das anomalias cromossômicas 34

Figura 5 - Cariótipo parcial de homens inférteis e os principais tipos de heteromorfismo de cromatina

Figura 6 - A estrutura do cromossomo Y humano 37

Figura 7 - Mapeamento e estrutura palindrômica da Região AZF. 39

Figura 8 - Correlação genótipo-fenótipo das microdeleções do cromossomo Y 41

Figura 9 - Modificações epigenéticas no genoma espermático. .46

Figura 10 - Representação da técnica de Hibridação Genômica Comparativa em

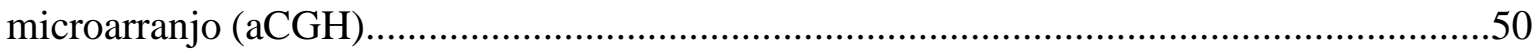

Figura 11 - Fluxograma da definição do grupo amostral

Figura 12 - Imagens dos géis de agarose evidenciando as duas reações (A e B) da PCR multiplex utilizada na detecção das microdeleções de AZF......

Figura 13 - Etapa de hibridação da técnica de Hibridação Genômica Comparativa. 70

Figura 14 - Distribuição das alterações genômicas no grupo controle e no grupo azoospermia não obstrutiva. .75

Figura 15 - Distribuição do número de alterações genômicas em ambos os grupos. .77

Figura 16 - Distribuição dos diferentes tipos de variantes de número de cópias (CNVs) e a média de indivíduos em cada grupo. .78

Figura 17 - Distribuição do tamanho das variantes de número de cópias (CNVs) pela média de indivíduos no grupo amostral e controle.

Figura 18 - Distribuição das variantes de número de cópias (CNVs) pela média de indivíduos nos grupos amostral e controle nos diferentes cromossomos

Figura 19 - Distribuição das variantes de número de cópias (CNVs) do tipo ganho e perda, pela média de indivíduos em ambos os grupos, nos diferentes cromossomos. .81

Figura 20 - Fluxograma da distribuição das CNVs do tipo ganho..............................................84

Figura 21 - CNV do tipo ganho, restrita ao grupo amostral, individual e rara localizada, em $7 \mathrm{q} 36.3 \ldots . . .87$ 
Figura 22 - CNV do tipo ganho, restrita ao grupo amostral, individual, rara e sem descrição no DGV, localizada em Xq21.1.

Figura 23 - CNV do tipo ganho, compartilhada por indivíduos de grupo amostral e localizada em 17q21.33 .89

Figura 24 - Fluxograma da distribuição das CNVs do tipo perda. 92

Figura 25 - CNV do tipo perda detectada em 3p21.2-21.31 em paciente com azoospermia não obstrutiva......

Figura 26 - CNV do tipo perda, compartilhada e codificante de proteína detectada em $15 q 11.2$.

Figura 27 - CNV do tipo perda, compartilhada e codificante de proteína detectada em $2 \mathrm{q} 31.1$...... .97

Figura 28 - CNVs do tipo ganho detectadas no cromossomo $\mathrm{Y}$ 100

Figura 29 - Distribuição do tamanho das regiões de LOH pela média de indivíduos no grupo amostral e controle.

Figura 30 - Distribuição das regiões de perda de heterozigose (LOH), pela média de indivíduos nos grupos amostral e controle, nos diferentes cromossomos 102

Figura 31 - Fluxograma da distribuição das regiões de LOH. 103

Figura 32 - LOH restrita ao grupo amostral, compartilhada e com genes codificantes de proteína detectada em $1 \mathrm{p} 31.1$....

Figura 33 - LOH restrita ao grupo amostral, compartilhada e com genes codificantes de proteína detectada em 7q21.1 108

Figura 34 - LOH restrita ao grupo amostral, compartilhada e com genes codificantes de proteína detectada em 12q21.1-21.2. 109 


\section{LISTA DE TABELAS}

Tabela 1 - Critérios de exclusão para a seleção da amostra...................................................61

Tabela 2 - Lista dos loci e a sequência dos primers utilizados na PCR multiplex para análise das microdeleções de AZF.

Tabela 3 - Comparação dos parâmetros clínicos entre os grupos de estudo

Tabela 4 - Avaliação quantitativa das alterações genômicas detectadas no grupo controle

(C1-C6) e no grupo de pacientes com azoospermia não obstrutiva idiopática (A-P).............76

Tabela 5 - CNVs do tipo ganho, restritas ao grupo amostral, individuais e raras..................85

Tabela 6 - CNVs do tipo ganho, restritas ao grupo amostral, compartilhadas e raras............86

Tabela 7 - CNVs do tipo perda, restritas, individuais e codificantes de proteína.....................93

Tabela 8 - CNVs do tipo perda, restritas, compartilhadas e codificantes de proteína............94

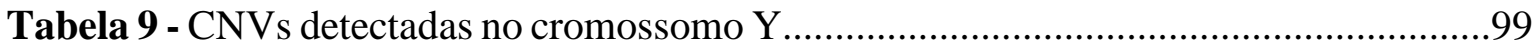

Tabela 10 - Regiões de LOH restritas, compartilhadas entre indivíduos do grupo amostral e que apresentavam genes relacionados à fertilidade. 104 


\section{LISTA DE ABREVIATURAS e SIGLAS}

ACG

AIFE

ANO

$\mathrm{AO}$

AR

array-CGH

ASRM

AURKC

$\mathrm{AZF}$

BAC

BSA

CBAVD

cDNA

CAP

CEP

CFTR

$\mathrm{CNV}$

Cy3

Cy5

DDG

DDS

DECIPHER

DGV

DHT

DIANA-miRPath

DNA

dNTP

$\mathrm{E}_{2}$

EAA
Aplasia de Células Germinativas

Ambulatório de Infertilidade Conjugal do HCFMRP/USP

Azoospermia Não Obstrutiva

Azoospermia Obstrutiva

do inglês, Androgen Receptor

do inglês, Comparative Genomic Hybridization array

do inglês, American Society for Reproductive Medicine

do inglês, Aurora Kinase C

do inglês, Azoospermic Factor

do inglês, Bacterial Artificial Chromosome

do inglês, Bovine Serum Albumin

do inglês, Congenital Bilateral Absence of Vas Deferens

do inglês, complementary DNA

do inglês, Catabolite Activator Protein

Comissão de Ética em Pesquisa

do inglês, Cystic Fibrosis Transmembrane Conductance Regulator

do Inglês, Copy Number Variation

Cianina 3

Cianina 5

Distúrbio da Diferenciação Gonadal

Distúrbio de Diferenciação Sexual

do inglês, Database of Chromosomal Imbalance and Phenotype in

Humans using Ensemble Resources

do inglês, Database of Genomic Variants

Diidrotestosterona

Banco de dados online para avaliação de miRNAs

do inglês, Deoxyribonucleic acid

do inglês, Deoxynucleotide triphosphate

$17 \beta$ estradiol

do inglês, European Academy of Andrology 


\begin{tabular}{|c|c|}
\hline ECARUCA & $\begin{array}{l}\text { do inglês, European Cytogeneticists Association Register of } \\
\text { Unbalanced Chromosome Aberrations }\end{array}$ \\
\hline EDTA & Ácido Etilenodiamino Tetra-Acético \\
\hline EMQN & do inglês, European Molecular Genetics Quality Network \\
\hline EUA & Estados Unidos da América \\
\hline FASST2 & do inglês, Fast Adaptive States Segmentation Technique \\
\hline FDA & do inglês, Food and Drug Administration \\
\hline FMRP/USP & $\begin{array}{l}\text { Faculdade de Medicina de Ribeirão Preto da Universidade de São } \\
\text { Paulo }\end{array}$ \\
\hline FSH & do inglês, Follicule-Stimulating Hormone \\
\hline GEN-3 & Ambulatório de Genética Médica 3 do HCFMRP/USP \\
\hline GeneOntology & Banco de dados com a descrição de genes e seus produtos \\
\hline GLIPR1 & do inglês, Glioma Pathogenesis-Related 1 \\
\hline GnRH & do inglês, Gonadotropin-Releasing Hormone \\
\hline GTG & do inglês, G-bands by Trypsin using Giemsa \\
\hline GWAS & do inglês, Genome-Wide Association Studies \\
\hline HCFMRP/USP & $\begin{array}{l}\text { Hospital das Clínicas da Faculdade de Medicina de Ribeirão Preto } \\
\text { da Universidade de São Paulo }\end{array}$ \\
\hline hg19 & do inglês, human genome version 19 \\
\hline HS & Hipoespermatogênese \\
\hline $\mathrm{IHH}$ & do inglês, Idiopatic Hypogonadotropic Hypogonadism \\
\hline indel & do inglês, insertion/deletion polymorphism \\
\hline ISCA & do inglês, International Standards for Cytogenomic Arrays \\
\hline $\mathrm{KCl}$ & Cloreto de Potássio \\
\hline LH & do inglês, Luteinizing Hormone \\
\hline $\mathrm{LOH}$ & do inglês, Loss of Heterozygosity \\
\hline $\mathrm{MgCl}_{2}$ & Cloreto de magnésio \\
\hline miRNA & MicroRNA \\
\hline mirBase & Banco de dados de miRNA \\
\hline $\operatorname{mirDB}$ & Banco de dados de miRNA \\
\hline MSCI & do inglês, Meiotic Sex Chromosome Inactivation \\
\hline NGS & do inglês, Next-Generation Sequencing \\
\hline NOR & do inglês, Nucleolar Organizer Region \\
\hline
\end{tabular}




\begin{tabular}{ll}
\hline OAT & Oligoastenoteratozoospermia \\
OMIM & do inglês, Online Mendelian Inheritance in Man \\
OMS & Organização Mundial de Saúde \\
OR & do inglês, Olfactory Receptor \\
PCR & do inglês, Polymerase Chain Reaction \\
pH & Potencial de Hidrogênio \\
PMCG & Parada de Maturação de Células Germinativas \\
PubMed & Arquivo online de artigos biomédicos e de Ciências da vida \\
RNA & do inglês, Ribonucleic Acid \\
ROS & do inglês, Reactive Oxygen Species \\
RPMI & acrônimo do inglês, Roswell Park Memorial Institute (meio de \\
SCOS & cultura) \\
SIPA & do inglês, Sertoli Cell-Only Syndrome \\
SNP & Síndrome da Insensibilidade Androgênica Parcial \\
SNV & do inglês, Single Nucleotide Polymorphism \\
SRY & do inglês, Single Nucleotide Variant \\
STS & do inglês, Sex-determining Region Y \\
TCLE & do inglês, Sequence-Tagged sites \\
TE & Termo de Consentimento Livre e Esclarecido \\
TESE & Tampão Tris-EDTA inglês, Testicular Sperm Extraction \\
VEGF & do inglês, Vascular Endothelial Growth Factor \\
VUS & do inglês, World Health Organization \\
WHO &
\end{tabular}




\section{LISTA DE SÍMBOLOS}

\begin{tabular}{ll}
\hline${ }^{\circ} \mathrm{C}$ & Graus Celsius \\
$g$ & Unidade de aceleração não pertencente ao Sistema Internacional \\
$\mathrm{h}$ & Hora \\
$\mathrm{pb}$ & Par de base \\
$\mathrm{kb}$ & Quilobase \\
$\mathrm{kd}$ & Quilodalton \\
$\mathrm{M}$ & Molar \\
$\mathrm{Mb}$ & Megabase \\
$\mu \mathrm{L}$ & Microlitro \\
$\mathrm{mL}$ & Mililitro \\
$\mathrm{mM}$ & Milimol \\
$\mathrm{dL}$ & Decilitro \\
$\mathrm{ng}$ & Nanograma \\
$\mathrm{n}$ & Micrograma \\
$\mathrm{ng}$ & Bnidade Internacional \\
$\mathrm{p}$ & Braço curto do cromossomo \\
$\mathrm{r}$ & Rotação por minuto \\
\hline
\end{tabular}




\section{SUMÁRIO}

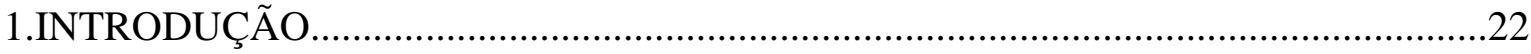

1.1 Infertilidade Conjugal e o Impacto do Fator Masculino....................................22

1.2 Infertilidade por Fator Masculino e a Investigação de um Fenótipo

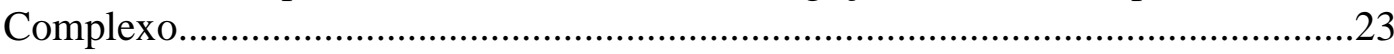

1.3 Etiologia da Infertilidade por Fator Masculino..............................................26

1.3.1 Alteração do Funcionamento do Eixo Hipotálamo-Hipófise-Gônada (Causas

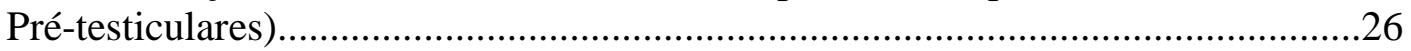

1.3.2 Causas Disfuncionais e a Obstrução Ductal (Causas Pós-testiculares)............28

1.3.3 Falência Espermatogênica Primária (Causas Testiculares)............................31

1.4 Genômica na Infertilidade Masculina Idiopática............................................47

1.4.1 Genoma humano e suas variantes...........................................................4

1.4.2 As Plataformas de Análise Genômica.........................................................49

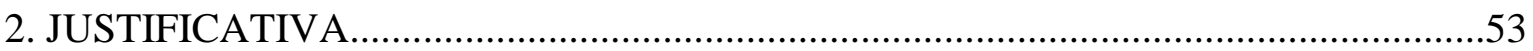

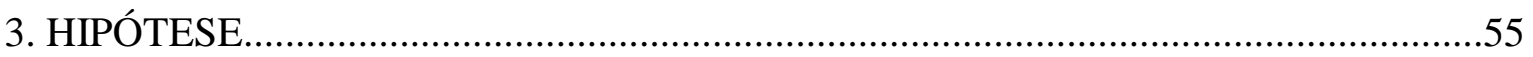

4. OBJETIVOS

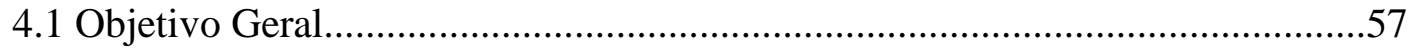

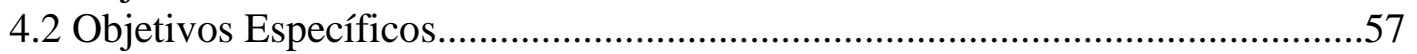

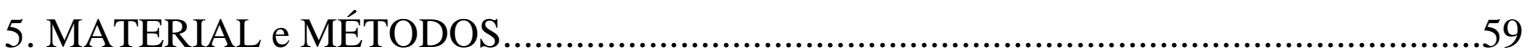

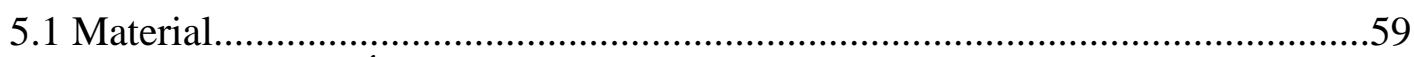

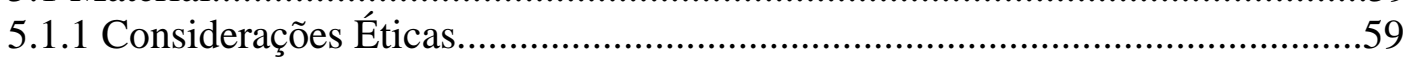

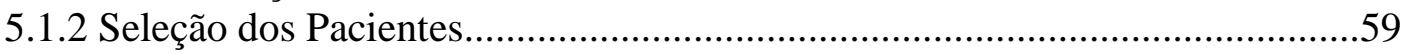

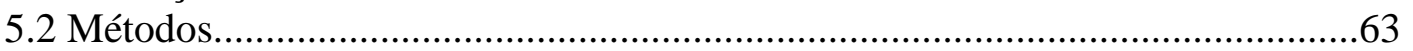

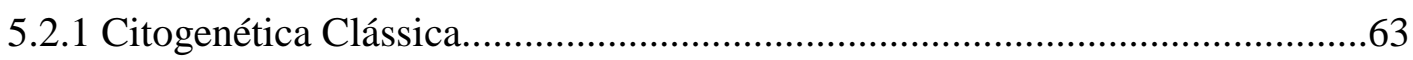

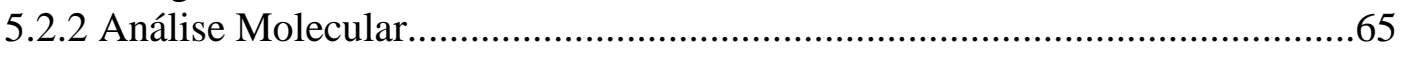

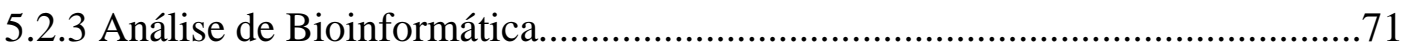

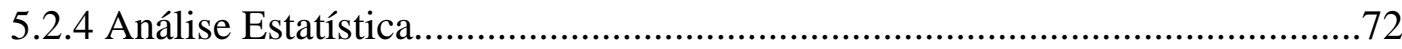

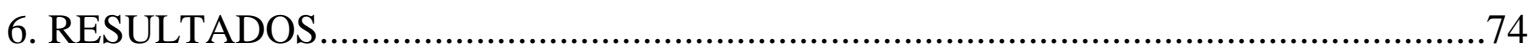

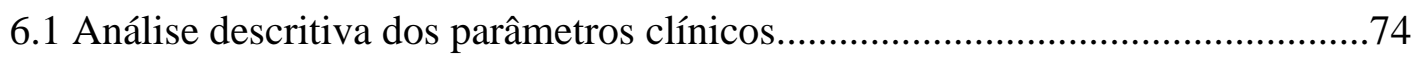

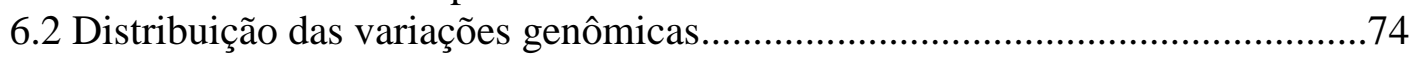

6.2.1 Distribuição e comparação entre grupos das Variantes de Número de Cópias

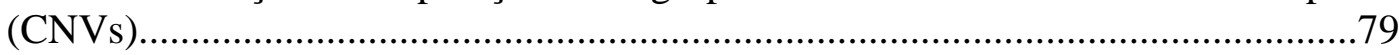

6.2.1.1 Distribuição e comparação entre grupos das Variantes de Número de Cópias

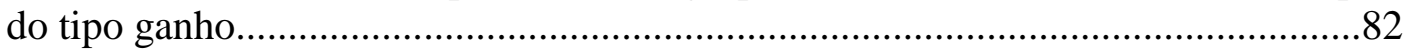

6.2.1.2 Distribuição e comparação entre grupos das Variantes de Número de Cópias

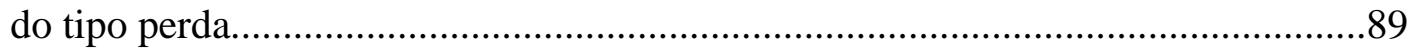

6.2.2 Distribuição e comparação entre grupos das regiões de perda de

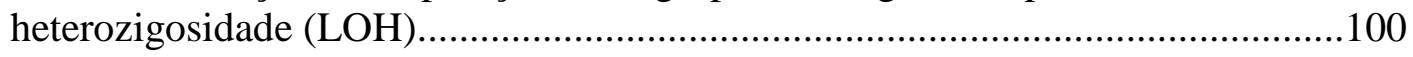

7. DISCUSSÃO

7.1 Análise das variantes de número de cópias...................................................111

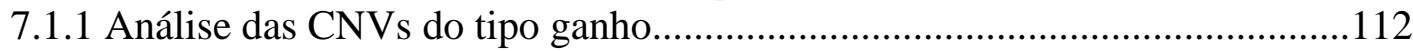

7.1.2 Análise das CNVs do tipo perda..............................................................116 
7.1.3 Análise das CNVs do tipo ganho localizadas no cromossomo Y

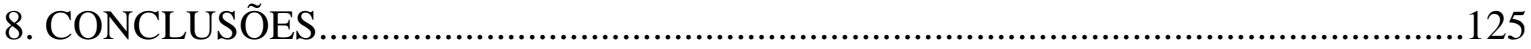

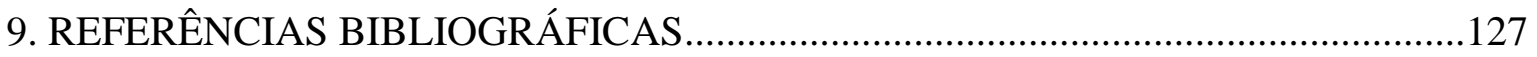

10. APENDICES

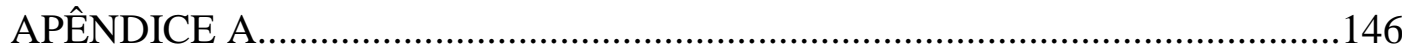

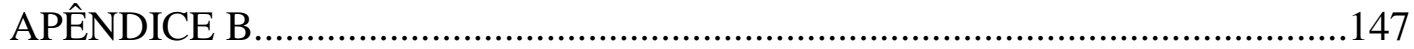

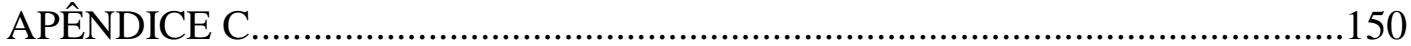

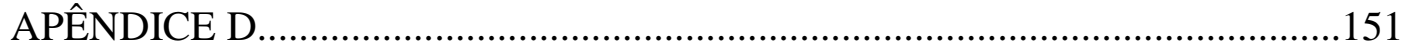

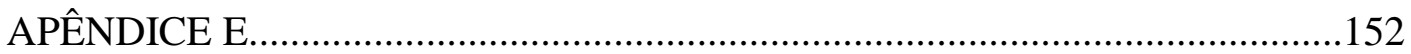

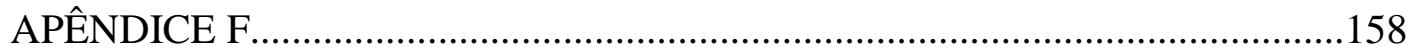

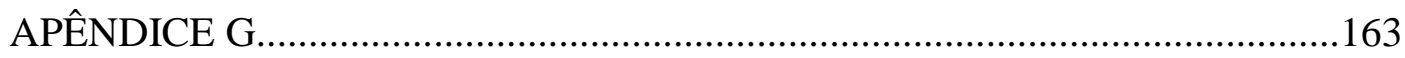

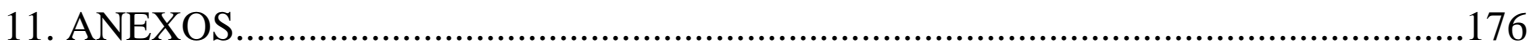




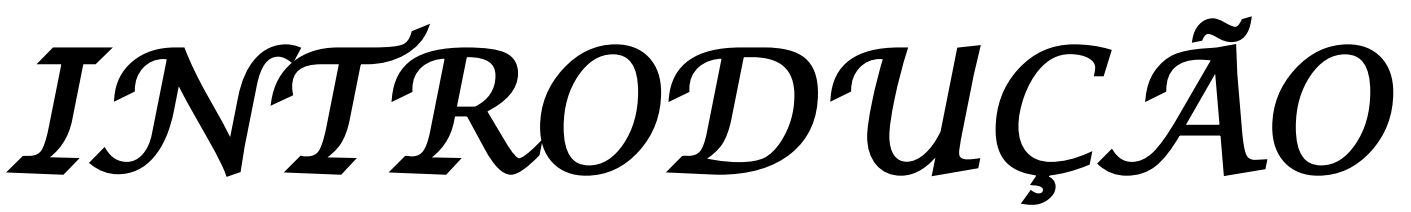

No princípio era a simplicidade... 


\section{INTRODUÇÃO}

\subsection{Infertilidade Conjugal e o Impacto do Fator Masculino}

A reprodução é uma etapa fundamental na vida não só de um indivíduo, mas da população como um todo. Problemas relacionados com a fertilidade têm implicações médicas, psicossociais e econômicas, resultando em estresse psicológico, particularmente em uma estrutura social com forte ênfase na fertilidade (SMITH et al., 2014; KUMAR \& SINGH, 2015; TOURNAYE et al., 2016; MUMTAZ et al., 2017).

Infertilidade conjugal é definida clinicamente como uma doença do aparelho reprodutivo caracterizada pela incapacidade de concepção após 12 meses de intercursos sexuais de forma regular e sem a utilização de métodos contraceptivos (ZEGERSHOCHSCHILD et al., 2009; WHO, 2010; BISHT et al.; 2017). Deve ser entendida como um problema de saúde pública que afeta 15 a $20 \%$ dos casais ao redor do mundo, o que corresponde a mais de 100 milhões de pessoas (INHORN \& PATRIZIO, 2015; KHERRAF et al., 2017).

Os primeiros dados sobre a prevalência de infertilidade por fator masculino surgiram no início da década de 1990 nas clínicas de fertilidade. Naquela época, 10\% da população masculina em idade reprodutiva procurava avaliação e em $20 \%$ desses homens, algum fator relacionado com infertilidade era identificado. A maioria dos casos estava relacionada aos fatores feminino ou não era investigada (SMITH et al.; 2014).

Atualmente, o fator masculino é responsável por metade dos casos de infertilidade conjugal, sendo $20 \%$ como fator isolado e $30 \%$ associado ao fator feminino (ASRM, 2015). Essa frequência apresenta diferenças regionais. As maiores prevalências são observadas no Leste Europeu e Oriente Médio, enquanto que o continente africano e regiões da Ásia registram menor impacto do fator masculino na infertilidade conjugal (Figura 1). Essa distribuição heterogênea se deve à escassez de dados estatísticos sobre a fertilidade masculina que, por sua vez, pode ser explicada pelos seguintes fatores:

a) Viés de aferição, na medida em que apenas uma parcela dos homens procura assistência médica para investigar problemas associados à fertilidade;

b) Fatores sociais, uma vez que o diagnóstico de infertilidade masculina ainda é tabu em alguns países onde as sociedades patriarcais predominam (norte da África e Oriente); 
c) Ausência de registro, já que a infertilidade masculina só foi considerada como doença há algumas décadas (WINTERS \& WALSH, 2014; AGARWAL et al., 2015).

Figura 1 - Representação da distribuição global dos casos de infertilidade devido ao fator masculino

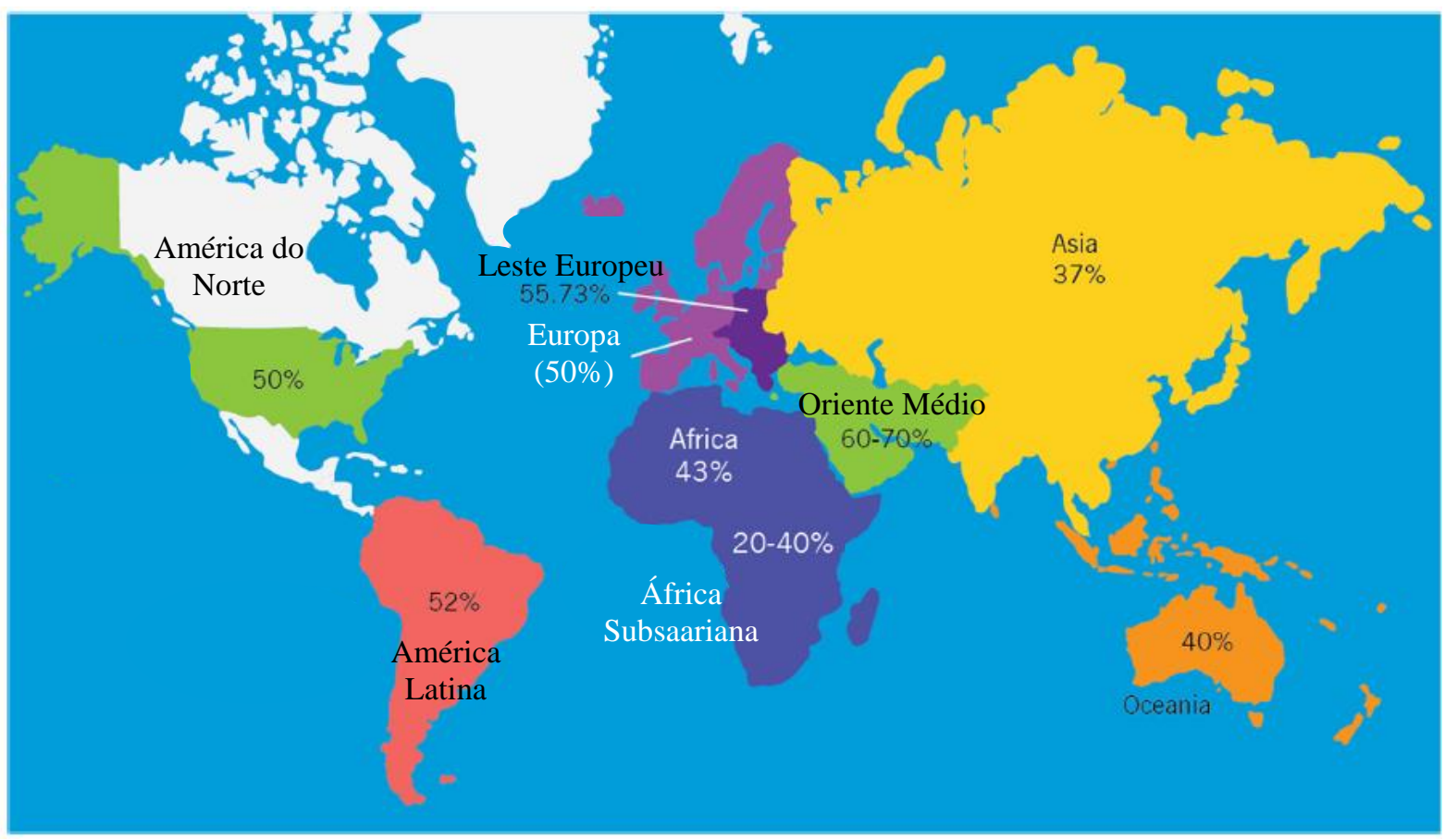

A figura demonstra a heterogeneidade da prevalência de infertilidade por fator masculino em escala global. O Leste Europeu e Oriente Médio apresentam maior prevalência, enquanto que países africanos e outras regiões da Ásia, devido a questões culturais e à ausência de investigação especializada, respondem por um menor número de casos. Dados mais precisos e confiáveis são provenientes das agências de saúde americana e europeia. (Adaptado de AGARWAL et al., 2015).

\subsection{Infertilidade por Fator Masculino e a Investigação de um Fenótipo Complexo}

A infertilidade por fator masculino é um fenótipo complexo que integra múltiplos órgãos, tais como: hipotálamo, hipófise e gônadas, além de processos biológicos intrinsicamente regulados como a espermatogênese. Deve ser compreendida como um espectro clínico no qual cada indivíduo contribui com um conjunto de diferenças genéticas, proteômicas e metabólicas que interagem de forma complexa (KOVAK et al., 2013; ASERO et al., 2014; NAGIRNAJA et al., 2017).

Muitos fatores parecem contribuir para o fenótipo, tais como idade, obesidade, exposição a agentes químicos e físicos, doenças infecciosas ou sistêmicas, efeitos adversos 
a medicações, alterações imunológicas, hormonais, psicológicas e fatores genéticos, levando à alteração da espermatogênese (RATO et al., 2012; LEAVER, 2016; BIENIEK et al., 2016).

A investigação dessa doença complexa necessita de uma estratégia diagnóstica baseada, inicialmente, na avaliação urológica com anamnese e exame físico detalhado, associada a exames complementares que incluem perfil hormonal, avaliação seminal e exames de imagem. Naqueles pacientes nos quais essa abordagem não foi elucidativa e que apresentam alteração da concentração espermática, o aconselhamento e a investigação genética tornam-se ferramentas essenciais na rotina diagnóstica (ANAWALT, 2013; GUDELOGLU \& PAREKATTIL, 2013; LEAVER, 2016; MITTAL et al., 2017).

O espermograma é o principal método de avaliação do potencial de fertilidade. Dentre outras características, ele analisa a função testicular (produção de espermatozoides), o funcionamento adequado dos outros componentes do sistema genital (glândulas acessórias) e a capacidade ejaculatória, além de auxiliar na complementação da rotina diagnóstica na infertilidade masculina (CENTOLA, 2014).

Os parâmetros seminais foram revisados em 2010 pela Organização Mundial de Saúde (OMS) que utilizou um grupo com cerca de dois mil homens, em sete países, de três continentes, que foram capazes de gerar descendência em até um ano após suspensão de métodos contraceptivos. Os valores obtidos de cada parâmetro foram distribuídos em uma curva normal gerando valores médios e intervalos de confiança. Valores maiores ou iguais ao percentil 5 (p5) foram considerados a referência para cada parâmetro. Dentre os principais parâmetros analisados no liquido seminal destacam-se a concentração de espermatozoides, a motilidade progressiva e a morfologia espermática (WHO, 2010; ESTEVES, 2016).

A partir da avaliação dos parâmetros seminais padronizados pela Organização Mundial da Saúde em 2010, foram estabelecidas as seguintes categorias:

a) Oligozoospermia: concentração espermática menor que 15 milhões de espermatozoides/mL no líquido seminal. Segundo a gravidade desse parâmetro, esses pacientes podem ser subclassificados em:

- Oligozoospermia leve: 10-15 milhões de espermatozoides/mL;

- Oligozoospermia moderada: 5-10 milhões de espermatozoides/mL;

- Oligozoospermia grave: < 5 milhões de espermatozoides/mL (SILBER \& DIETECHE, 2012; SMITH et al., 2014); 
b) Azoospermia: ausência de espermatozoides após duas centrifugações do líquido seminal, a $3000 \mathrm{~g}$, por 15 minutos;

c) Criptozoospermia: ausência de espermatozoides na avaliação seminal, porém com presença de algumas formas após a centrifugação do líquido seminal;

d) Astenozoospermia: redução da motilidade espermática $(<32 \%)$ avaliada pela motilidade progressiva. Resulta da soma da motilidade progressiva rápida e lenta;

e) Teratozoospermia: redução de formas normais dos espermatozoides $(<4 \%)$ pelo critério estrito de Tygerberg.

A combinação das alterações na concentração, motilidade e morfologia espermática resultam em oligoastenoteratozoospermia (OAT).

Pacientes com azoospermia são classificados em dois grupos para diferenciar a falha espermatogênica primária, que caracteriza a azoospermia não obstrutiva, do bloqueio do sistema ductal masculino (azoospermia obstrutiva). Essa distinção utiliza critérios clínicos e laboratoriais, que podem incluir a biópsia testicular e é essencial, na medida em que, esses dois tipos de alteração apresentam etiologia, avaliação e manejo completamente distintos (ALVARENGA \& PAGANI, 2013).

A azoospermia obstrutiva é observada em $40 \%$ dos homens com azoospermia e é caracterizada pelo bloqueio da função exócrina e da normalidade da função endócrina testicular. A azoospermia não obstrutiva, por sua vez, afeta cerca de $1 \%$ da população geral e $10-15 \%$ dos homens em avaliação por infertilidade. É caracterizada pela falha espermatogênica primária associada a três diferentes padrões de alteração histopatológica (ASRM, 2008; WOSNITZER et al., 2014; BEHRE et al., 2015):

a) Hipoespermatogênese (HS) ou parada incompleta da maturação espermática: todos os estágios da espermatogênese estão presentes, porém com redução, de grau variável, de todos os estágios de maturação. Inclui diferentes padrões de túbulos seminíferos. Alguns contendo apenas células de Sertoli, com hialinização dos túbulos, enquanto outros apresentam espermatogênese completa. Clinicamente, os pacientes apresentam oligozoospermia;

b) Parada completa da maturação de células germinativas (PMCG): caracterizada pela parada da progressão normal da espermatogênese, geralmente no estágio de espermatócito primário. Na microscopia óptica, são observadas numerosas espermatogônias, poucos espermatócitos, nenhum espermatozoide maduro e células 
de Sertoli proeminentes. Não há alteração da membrana basal e componente intersticial;

c) Aplasia de células germinativas (ACG) ou Sertoli Cell-Only Syndrome (SCOS): túbulos seminíferos de tamanhos reduzidos, apresentando células de Sertoli de histologia normal e ausência completa das células germinativas.

\subsection{Etiologia da Infertilidade por Fator Masculino}

Após extensa rotina diagnóstica, algum fator congênito ou adquirido pode ser detectado em metade dos pacientes em investigação por infertilidade masculina. Clinicamente, esses fatores podem ser classificados em três diferentes categorias (TOURNAYE et al., 2016):

\subsubsection{Alteração do Funcionamento do Eixo Hipotálamo-Hipófise-Gônada (Causas Pré-testiculares)}

A integridade da anatomia e fisiologia do sistema genital masculino, associado com o funcionamento correto de outros sistemas, como o endócrino, é crucial para a manutenção da fertilidade. A desregulação endócrina dos eixos hipotálamo-hipófise-gônada, hipotálamohipófise-adrenal e sistema adrenérgico pode alterar a produção de espermatozoides e hormônios pelo testículo, comprometendo a fertilidade masculina (NARGUND et al., 2015) (Figura 2).

As alterações do eixo hipotálamo-hipófise-testículo podem ser congênitas ou adquiridas e são clinicamente caracterizadas por hipogonadismo hipogonadotrófico, atraso puberal, redução dos caracteres sexuais, ginecomastia e redução do volume testicular (TOURNAYE et al., 2016).

As formas congênitas de hipogonadismo hipogonadotrófico são condições raras, de etiologia genética heterogênea, maior prevalência no sexo masculino (5 homens:1mulher) e caracterizadas por falência da função gonadal secundária aos defeitos de síntese, secreção ou ação anormal do hormônio liberador de gonadotrofinas (GnRH). Classicamente, são divididos em dois subtipos: 
Figura 2 - Eixo Hipotálamo-Hipófise-Testículo.

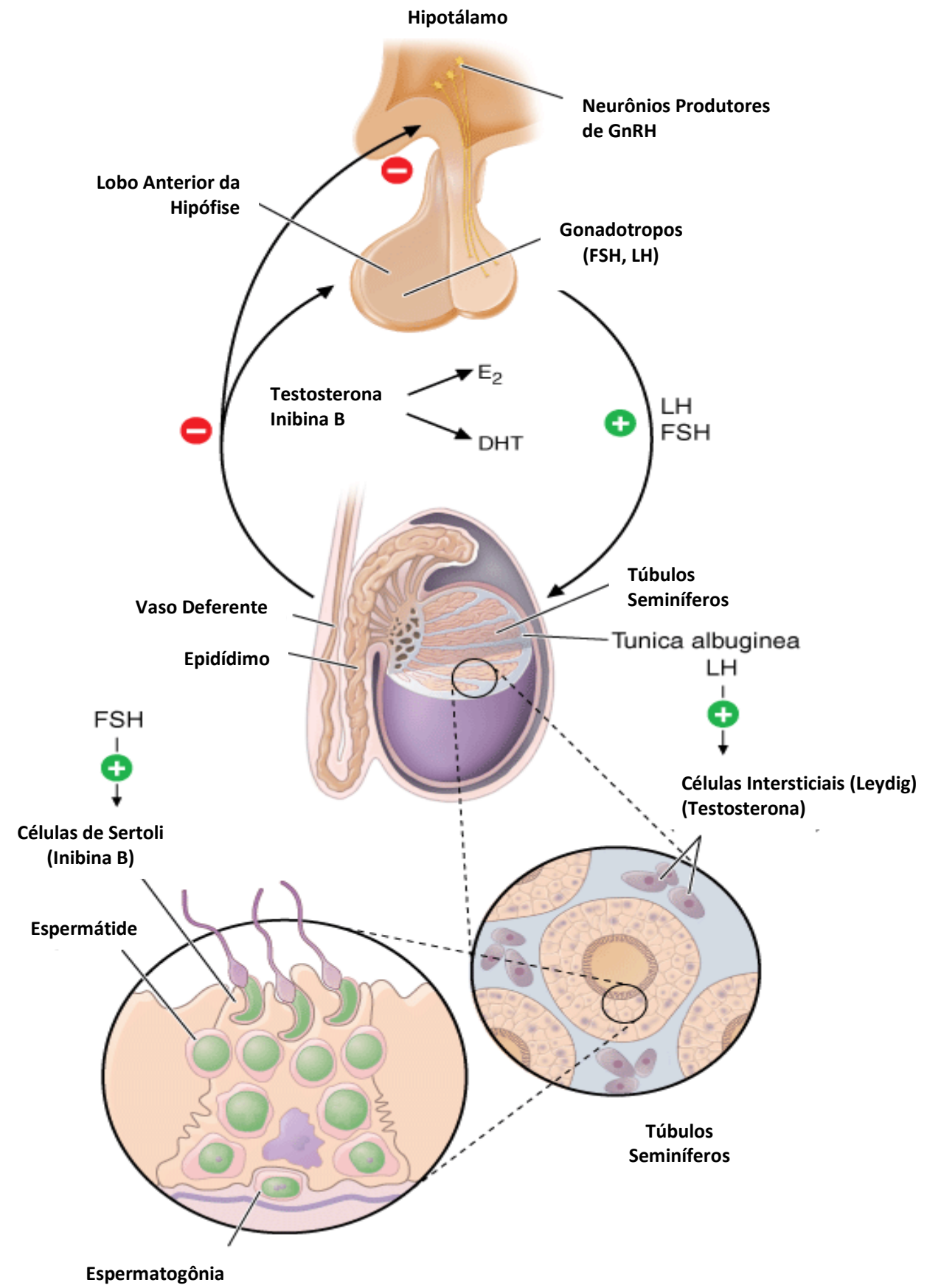

A figura evidencia como as gonadotrofinas humanas atuam na função endócrina e exócrina testicular. O GnRH hipotalâmico regula a produção das gonadotrofinas FSH e LH nos gonadotropos do lobo anterior da hipófise. O LH atua principalmente nas células de Leydig estimulando a síntese de testosterona (função endócrina), enquanto que o FSH atua nas células de Sertoli regulando a espermatogênese (função exócrina) e secreção de Inibina B, que irá suprimir seletivamente o FSH hipofisário. GnRH - Hormônio regulador da liberação de gonadotrofinas; FSH - Hormônio folículo estimulante; LH - Hormônio luteinizante; $\mathrm{E}_{2}$ - $17 \beta$ estradiol; DHT - diidrotestosterona (Adaptado de BHASIN \& JAMESON, In: Harrison's Principles of Internal Medicine, 2015). 
a) Sem distúrbio olfatório (normosmia): pode ocorrer de forma isolada ou associada com outras manifestações clínicas, como na síndrome de Prader-Willi e de Laurence-Moon-Biedl (BEROOKHIM et al., 2014);

b) Associado com distúrbio olfatório (anosmia ou hiposmia), caracterizando a Síndrome de Kallmann. Mais de 50 genes já foram associados com a migração dos neurônios produtores de GnRH e das fibras olfatórias do placoide respiratório para o prosencéfalo. Neste grupo, podemos observar malformações como fenda labial e/ou palatina, agenesia dentária e renal, além de alterações esqueléticas (AMATO et al., 2017).

As formas adquiridas de hipogonadismo hipogonadotrófico estão associadas ao uso exógeno de esteroides anabolizantes e ao comprometimento hipofisário por doenças autoimunes e infiltrativas como tuberculose, hemocromatose, sarcoidose, neoplasias e até mesmo, o tratamento para esses tumores (TOURNAYE et al., 2016).

A hiperprolactinemia é também considerada causa pré-testicular de infertilidade masculina, na medida em que reduz a libido e a produção de testosterona, seja pela inibição da liberação de gonadotrofinas ou pela redução da estimulação do LH sobre as células de Leydig (PAGANI et al., 2009).

\subsubsection{Causas Disfuncionais e a Obstrução Ductal (Causas Pós-testiculares)}

Qualquer interferência na integridade neurológica e anatômica do sistema de transporte dos espermatozoides da gônada ao meio externo pode levar à redução do potencial de fertilidade masculina. Nesses pacientes, a espermatogênese e o eixo hipotálamo-hipófisetestículo funcionam normalmente e clinicamente o paciente apresenta azoospermia obstrutiva (RAMALINGAM et al., 2014).

Os espermatozoides precisam se movimentar por uma série de canais que se originam na rede testis (intratesticular), passando pelos ductos eferentes e seguindo por epidídimos, canais deferentes, ductos ejaculatórios e uretra, para atingir o meio externo. Além disso, secreções provenientes das vesículas seminais e próstata são necessárias para compor o sêmen. Qualquer interferência nesse sistema de transporte, seja ela congênita ou adquirida, leva à infertilidade masculina de causa obstrutiva (WOSNITZER et al., 2014; TOURNAYE et al., 2016) (Figura 3). 
As causas congênitas representam a menor proporção da azoospermia obstrutiva e são caracterizadas pela hipoplasia ou aplasia dos vasos deferentes e das vesículas seminais que pode ocorrer tanto na forma unilateral ou bilateral, associada ou não à agenesia renal. A agenesia bilateral congênita dos vasos deferentes (CBAVD), classicamente, não tem associação com agenesia renal e sua etiologia está relacionada com diferentes mutações no gene da fibrose cística (CFTR) localizado em 7q31.2. A literatura ainda apresenta dados controversos quanto às formas unilaterais associadas à alteração renal (GAJBHIYE et al., 2016; SONG et al., 2017).

Figura 3 - Representação do corte sagital mediano da pelve e períneo masculino (A) e da visão posterior do sistema de transporte dos espermatozoides (B).
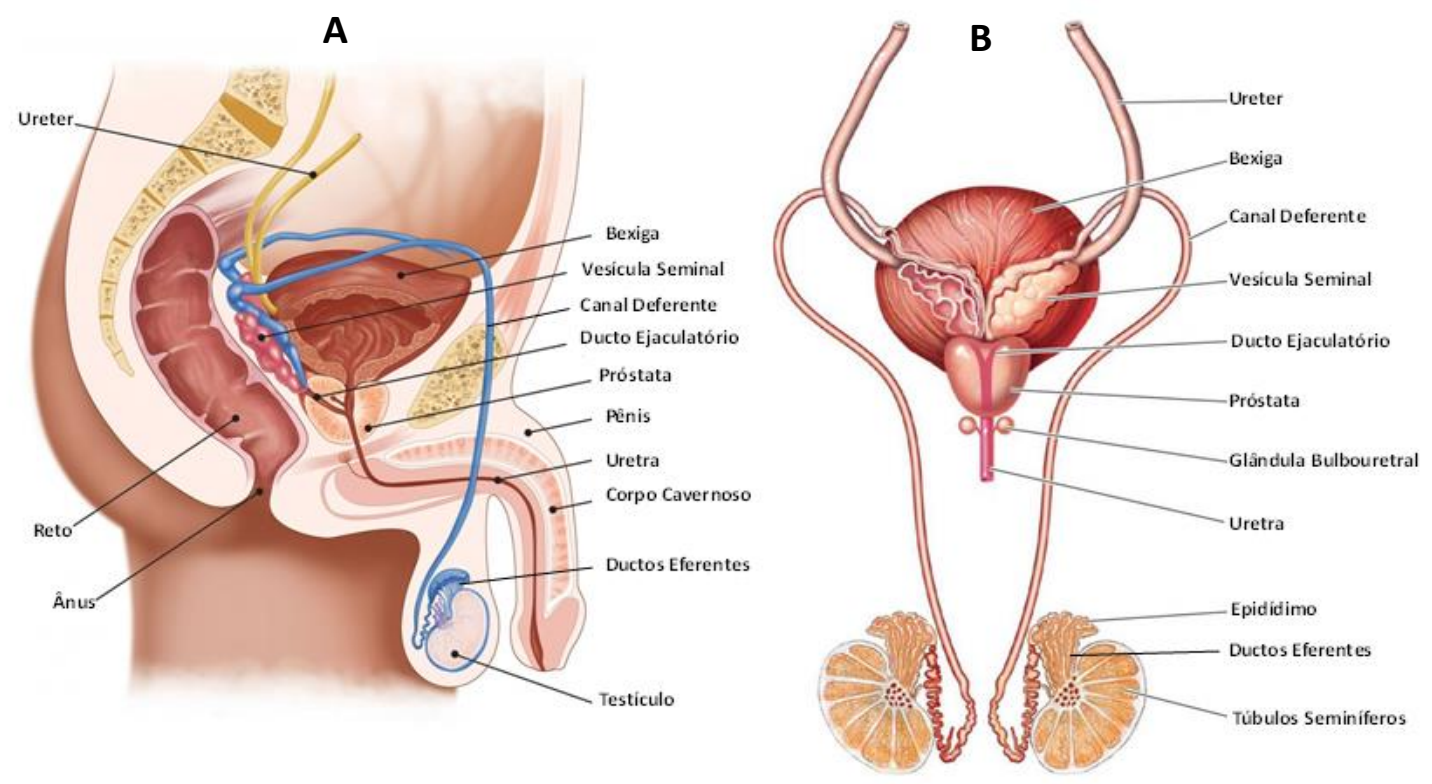

Os espermatozoides produzidos nos túbulos seminíferos dos testículos são armazenados e amadurecidos nos epidídimos (capacidade de motilidade progressiva). Durante a ejaculação as células reprodutivas são conduzidas pelos vasos deferentes que, por sua vez, se unem aos ductos das vesículas seminais para formar os ductos ejaculatórios. Cada ducto ejaculatório se abre sobre a parede posterior da uretra prostática onde recebem as secreções produzidas pela próstata e glândulas acessórias para formar o líquido seminal. (Adaptado de MODGIL et al., 2016).

Mais de 1000 mutações no gene $C F T R$, em homozigose ou heterozigose composta, podem resultar em pelo menos três fenótipos clínicos distintos (FIRTH et al., 2005):

a) Fibrose Cística Clássica: caracterizada por um quadro grave de doença pulmonar obstrutiva, bronquiectasias, insuficiência pancreática exócrina, elevação do íon 
cloreto no suor e infertilidade masculina (mais de 95\% dos pacientes apresentam CBAVD);

b) Fibrose Cística não clássica: caracterizada por doença pulmonar crônica e quadro variável das sintomatologias descritas anteriormente (insuficiência pancreática, elevação do íon cloreto no suor e infertilidade masculina);

c) Agenesia Bilateral Congênita de Vasos Deferentes: diagnosticada em 1\% dos homens em avaliação por infertilidade. Nesses pacientes, a única manifestação clínica é a azoospermia obstrutiva causada pela combinação de duas variantes patogênicas no gene CFTR. Homens com CBAVD geralmente são heterozigotos compostos para dois alelos associados com forma branda de fibrose cística ou da combinação de um alelo associado com forma branda, com outro de forma grave. Além disso, o polimorfismo no sítio aceptor de splicing do intron 8 do gene CFTR influencia quantitativamente na produção do canal regulador transmembrana da fibrose cística (SONG et al., 2016).

As causas mais comuns de obstrução do ducto ejaculatório são adquiridas e representadas por vasectomia ou por alterações dos epidídimos, vasos deferentes e ductos ejaculatórios relacionados com infecções, iatrogenia ou trauma local (WOSNITZER et al., 2014; HAN et al., 2016).

As causas disfuncionais são aquelas que alteram os processos de ereção e ejaculação que, por sua vez, requerem a integridade das vias simpáticas e parassimpáticas do sistema nervoso autônomo (IBRAHIM et al., 2016).

A neurofisiologia da ejaculação é um processo complexo que pode ser compreendido em fases. A primeira dessas fases é denominada de emissão e decorre da estimulação das vias simpáticas pelo nervo pudendo sobre os vasos deferentes, vesículas seminais e próstata, resultando na contração e deposição dos seus respectivos conteúdos na uretra posterior. Pacientes com neuropatia autonômica devido à doença microvascular como diabetes, apresentam ondas peristálticas anormais que comprometem o processo de emissão. A segunda etapa da ejaculação é denominada de expulsão e inicia-se com um arco reflexo especializado da medula espinhal (T12-L2) após a emissão. Nesse período, contrações rítmicas da musculatura periuretral levam à eliminação do sêmen em direção anterógrada. Dessa forma, qualquer interrupção do neuroeixo, a esse nível da medula, resultante de 
trauma, esclerose múltipla, mielite transversa ou defeito de fechamento de tubo neural, pode comprometer o processo ejaculatório (TOURNAYE et al., 2016).

\subsubsection{Falência Espermatogênica Primária (Causas Testiculares)}

A falência espermatogênica primária gera deficiência na produção espermática que culminará com o fenótipo clínico de oligozoospermia grave ou azoospermia não obstrutiva. Assim como os outros fatores descritos anteriormente, apresenta etiologia diversa que pode ser agrupada em três grupos: as causas congênitas, adquiridas e idiopáticas.

A varicocele é considerada a causa reversível mais comum de infertilidade masculina adquirida. É uma patologia complexa definida como uma dilatação e tortuosidade anormal das veias espermáticas internas do plexo pampiniforme no cordão espermático e está associada com efeitos negativos sobre a qualidade seminal, função espermática, histologia testicular e alteração da produção hormonal (JENSEN et al., 2017).

Os mecanismos patogênicos subjacentes à varicocele são estase venosa, hipóxia e aumento de citocinas inflamatórias que resultam em indução da apoptose e danos oxidativos por espécies reativas de oxigênio. As alterações espermáticas observadas na varicocele parecem não apresentar relação direta com a sua gravidade e são caracterizadas pelo aumento do índice de fragmentação do DNA, aumento do estresse oxidativo, inatividade mitocondrial e reação acrocêntrica anormal. (LACERDA et al., 2011; SHIRAISHI \& NAITO, 2008; JENSEN et al., 2017).

Traumas locais como a torção testicular, lesões inflamatórias secundárias à caxumba, doenças sistêmicas como falência hepática e insuficiência renal, além dos tumores testiculares são exemplos de causas adquiridas de falha espermatogênica (COCUZZA, et al., 2013).

Já a anorquia, a criptorquidia e as alterações genéticas são exemplos de causas congênitas relacionadas à falência testicular. A criptorquidia é uma das anomalias congênitas mais comuns do aparelho reprodutor masculino e resulta da falha de migração completa do testículo até a bolsa escrotal. Apresenta etiologia multifatorial e sua prevalência é de $5 \%$ em recém-nascidos do sexo masculino a termo, $15 \%$ em prematuros e $0,5 \%$ em adultos (SINGH et al., 2012; BRAGA \& LORENZO, 2017). 


\subsubsection{Alterações Genéticas da Falência Espermatogênica Primária}

As anormalidades genéticas contribuem com $15-30 \%$ da infertilidade por fator masculino e influenciam uma variedade de processos fisiológicos incluindo a homeostase hormonal, espermatogênese e a qualidade espermática, resultando em alterações na concentração (causas quantitativas), morfologia e motilidade dos espermatozoides (qualitativas) (FERLIN et al., 2007; SUGANYA et al., 2015).

A falência espermatogênica primária decorre da alteração do processo de espermatogênese. No início da puberdade masculina, células, localizadas nos túbulos seminíferos dos testículos, iniciarão esse processo complexo e geneticamente regulado de produção de gametas masculinos, a partir de células-tronco especiais. Sequencialmente, essas cúlulas passarão por três diferentes tipos de divisão celular que incluem as divisões mitóticas, meióticas e de diferenciação celular (MASSART et al., 2012; EGGERS et al., 2015; JAISWAL et al., 2015; TOURNAYE et al., 2016).

As anomalias cromossômicas numéricas e estruturais, os heteromorfismos, as microdeleções no braço longo do cromossomo $\mathrm{Y}$, as mutações de ponto em genes autossômicos e ligados ao $\mathrm{X}$ e as alterações epigenéticas são fatores genéticos que comprometem a espermatogênese (FLANNIGAN et al., 2017).

\subsection{As anomalias cromossômicas}

A frequência de anomalias cromossômicas na população masculina infértil (2-10\%) é cerca de 10 vezes maior que a observada na população geral $(0,6 \%)$ e é inversamente proporcional à produção espermática. Homens com produção normal de espermatozoides apresentam menos que $1 \%$ de anomalias cromossômicas, seguido por $5 \%$ nos oligozoospérmicos graves e em 10-15\% naqueles com azoospermia não obstrutiva, justificando a análise citogenética em todo homem com redução do potencial de fertilidade (PYLYP et al., 2013; FLANNIGAN \& SCHLEGEL, 2017).

A gravidade dessas alterações também segue esse padrão, uma vez que homens com oligozoospermia apresentam mais comumente alterações estruturais, enquanto que os azoospérmicos têm frequência aumentada de aneuploidias (SMITH et al., 2014; XIE et al., 2017) (Figura 4). 
As alterações cromossômicas estruturais, dentre elas as translocações e as inversões, são resultantes de quebras seguidas de reconstituição cromossômica anormal e podem ser herdadas ou surgir "de novo" quando derivadas de erros durante a divisão celular pószigótica. As alterações no pareamento e na segregação correta dos cromossomos durante a divisão meiótica levam à parada de maturação espermática, resultando em infertilidade (GODO et al., 2013; ROUKOS \& MISTELI, 2014; BEHRE et al., 2015; NETO et al., 2016; XIE et al., 2017).

A Síndrome de Klinefelter é considerada a causa genética mais comum de infertilidade masculina. É uma alteração cromossômica numérica observada em 1/600 nascimentos do sexo masculino. Apresenta grande variabilidade clínica dificultando o diagnóstico. Acredita-se que apenas 30\% dos pacientes com Síndrome de Klinefelter sejam identificados. A maior proporção desses indivíduos é observada na população masculina infértil, mais precisamente, em 0,6\% dos homens com oligozoospermia grave e em 10 - 15\% dos azoospérmicos não obstrutivos. De acordo com a alteração cromossômica, duas formas podem ser diferenciadas. A forma clássica, com cariótipo 47,XXY, presente em 80-90\% dos pacientes e a não clássica, evidenciada por mosaicismo cromossômico 46,XY/47,XXY.

Essas alterações cromossômicas levam à disgenesia testicular progressiva, resultando em degeneração das células que compõem os túbulos seminíferos e à hipertrofia das células de Leydig, que irão resultar no hipogonadismo hipergonadotrófico. Os mecanismos genéticos subjacentes que levam à degeneração testicular ainda não são totalmente conhecidos, mas acredita-se que a superexpressão de genes ligados ao cromossomo X, relacionados com a via inflamatória, manutenção da integridade da barreira hematotesticular, regulação do receptor de FSH e aumento da atividade da aromatase, estejam associados (D’AURORA et al., 2015; NETO et al., 2016; BONOMI et al., 2017).

A Síndrome do duplo Y (47,XYY), também denominada de síndrome de Jacobs, tem incidência em 1/1000 nascimentos do sexo masculino e, após a síndrome de Klinefelter, é a aneuploidia mais frequente em homens inférteis. Na maioria das vezes, o erro de segregação ocorre na meiose II paterna, porém a não-disjunção cromossômica também pode ocorrer, em 15\% dos casos, na mitose pós-zigótica. Em geral, esses homens não apresentam malformações menores ou maiores e podem ter histórico de atraso de linguagem e dificuldade de comunicação. A maioria apresenta espermatogênese normal e filhos saudáveis. No entanto, de acordo com a literatura, a presença adicional do cromossomo $\mathrm{Y}$ 
pode resultar em alteração do pareamento cromossômico, levando à redução da produção espermática ou, até mesmo, a formação de espermatozoides dissômicos. Nesses pacientes o espermograma típico evidencia oligozoospermia (NETO et al., 2016; BOROUJENI et al., 2017).

Figura 4 - Relação entre a concentração espermática e a prevalência das anomalias cromossômicas.

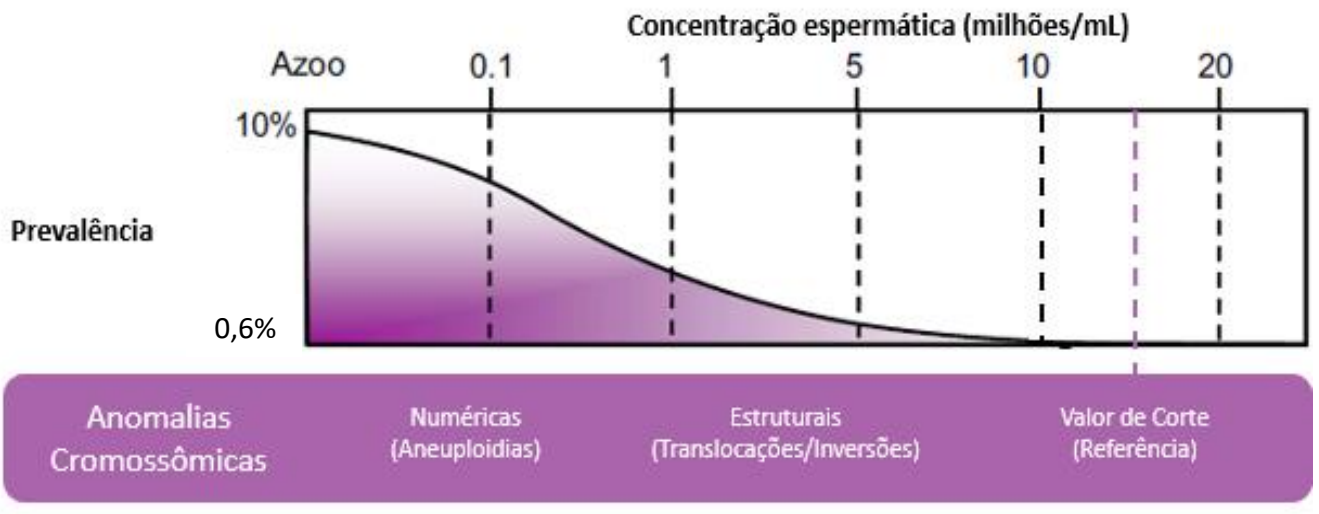

Da direita para a esquerda, o gráfico evidencia a redução gradual da concentração espermática associada ao aumento da prevalência e da gravidade das anomalias cromossômicas. Indivíduos sem alteração da concentração espermática apresentam a frequência populacional de anomalias cromossômicas, enquanto que indivíduos com oligozoospermia, mais comumente, apresentam alterações estruturais e aqueles com oligozoospermia grave e azoospermia, além de apresentarem risco dez vezes maior que a população geral, concentram anomalias cromossômicas mais graves (Adaptado de MCLACHAN \& O’BRYAN, 2010).

A síndrome do homem XX, antigamente denominada de Síndrome de La Chapelle ou sexo reverso, é atualmente considerada um exemplo de distúrbio de diferenciação sexual (DDS) por alteração da diferenciação gonadal (DDG) do tipo testicular. Corresponde a uma alteração rara com incidência de 1/20.000 nascimentos do sexo masculino, podendo ser diferenciada em duas variantes.

A primeira, responsável por 80-90\% dos casos, resulta da fecundação de um ovócito normal por um espermatozoide carregando um cromossomo $\mathrm{X}$ translocado com segmento SRY (região determinante do sexo). Esses pacientes apresentam genitália externa masculina e podem apresentar atraso puberal, ginecomastia e infertilidade devido à ausência dos genes reguladores da espermatogênese localizadas na região de AZF.

A segunda, denominada SRY negativa, está associada com mutações em genes autossômicos ou ligados ao X, como $S O X 9$ e $D A X 1$, também envolvidos na cascata de 
determinação sexual. Nestes pacientes pode ocorrer masculinização incompleta resultando em genitália ambígua (HOTALING \& CARRELL, 2014; NETO et al., 2016).

Os heteromorfismos são variações no tamanho de parte da estrutura de alguns cromossomos decorrentes da amplificação de regiões de DNA altamente repetitivo, pobre em genes codificantes. Existem dois tipos principais desse tipo de alteração. Os heteromorfismos de heterocromatina, presentes nos cromossomos 1, 9, 16 e Y e que podem ser observados pela técnica de bandamento $\mathrm{C}$ e os heteromorfismos dos braços curtos, satélites e hastes dos satélites dos cromossomos acrocêntricos 13, 14, 15, 21 e 22. Essas regiões contêm DNA moderadamente repetitivo, com sequências de genes ribossômicos e com proteínas que têm afinidade por prata. Dessa forma, podem ser analisadas pela técnica de bandamento NOR (Região Organizadora do Nucléolo).

Essas variantes são observadas em 2-5\% da população fenotipicamente normal, porém com maior prevalência em indivíduos inférteis (três a cinco vezes maior) ou em casais com má história obstétrica (abortamento de repetição e falha de implantação). Especula-se que o impacto dessas variantes na infertilidade esteja associado a alterações no pareamento e sinapse cromossômica, bem como na ligação dos cromossomos ao fuso e, por conseguinte, na própria divisão celular. Estudos recentes também questionam se essas regiões estão envolvidas com processos de regulação e modulação genômica (SAHIN, et al., 2008; TEMPEST \& SIMPSON 2017) (Figura 5).

\subsection{As Microdeleções da Região de AZF}

O cromossomo Y é o menor dos cromossomos humanos com cerca de $60 \mathrm{Mb}$ de comprimento e correspondendo a 2-3\% do genoma haploide. É classificado como acrocêntrico em relação a sua estrutura e difere marcadamente dos outros cromossomos quanto à estrutura genômica, ao conteúdo gênico e à trajetória evolutiva (BICHILE et al., 2014; KRAUSZ \& CASAMONTI, 2017).

Em termos estruturais, o cromossomo $\mathrm{Y}$ pode ser subdividido em duas regiões pseudoautossômicas (PARs) e na Região Específica Masculina (MSY). As regiões terminais de ambos os braços cromossômicos contêm as regiões pseudoautossômicas ricas em genes de homologia X-Y. A região pseudoautossômica 1 (PAR-1) localiza-se na parte distal do braço curto (Yp) e apresenta cerca de 24 genes distribuídos em cerca de 2,5Mb, com diversas funções biológicas e padrão de expressão variável. A PAR-2 localiza-se na região distal do 
braço longo (Yq) e apresenta cerca de 4 genes. Essas duas regiões estão associadas com o pareamento meiótico correto e possibilidade de permuta entre genes dos cromossomos $\mathrm{X}$ e Y na meiose paterna (BICHILE et al., 2014) (Figura 6).

Figura 5 - Cariótipo parcial de homens inférteis e os principais tipos de heteromorfismo de cromatina.

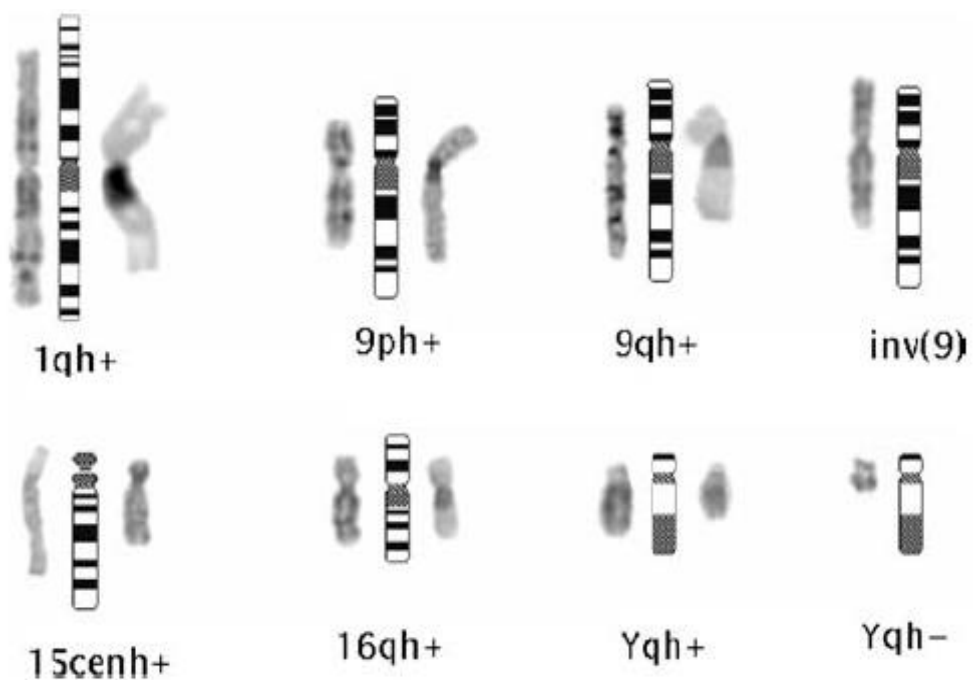

Na figura, observamos os heteromorfismos de heterocromatina dos cromossomos 1, 9, 16 e Y. Os símbolos (+) e (-) representam, respectivamente, o aumento e a diminuição do tamanho da região heterocromática (h). O heteromorfismo de inversão (inv) do cromossomo 9 e heteromorfismo de região centromérica (cen) do cromossomo 15 também estão representados. Para cada cromossomo há a representação do ideograma (centro), bandamento G (direita) e bandamento C (esquerda) (SAHIN, et al., 2008).

A região MSY corresponde a 95\% do cromossomo Y e é composta pelas regiões de eucromatina e heterocromatina que não apresentam recombinação com o cromossomo X. A região de heterocromatina é polimórfica na população e considerada geneticamente inerte por ser rica em DNA repetitivo não codificante. A região eucromática, por sua vez, apresenta três classes de sequências:

a) Região transposta do cromossomo X: corresponde a 15\% de MSY e apresenta $99 \%$ de homologia com a região $\mathrm{Xq21}$;

b) Regiões degeneradas do cromossomo X: correspondem a 20\% de MSY e apresentam 27 genes de cópia única e muitos pseudogenes;

c) Regiões de amplicons: correspondem a 30\% de MSY e incluem genes com expressão limitada ao testículo (SKALETSKY et al., 2003; KRAUSZ \& CASAMONTI, 2017) (Figura 6). 
Figura 6 - A estrutura do cromossomo Y humano.

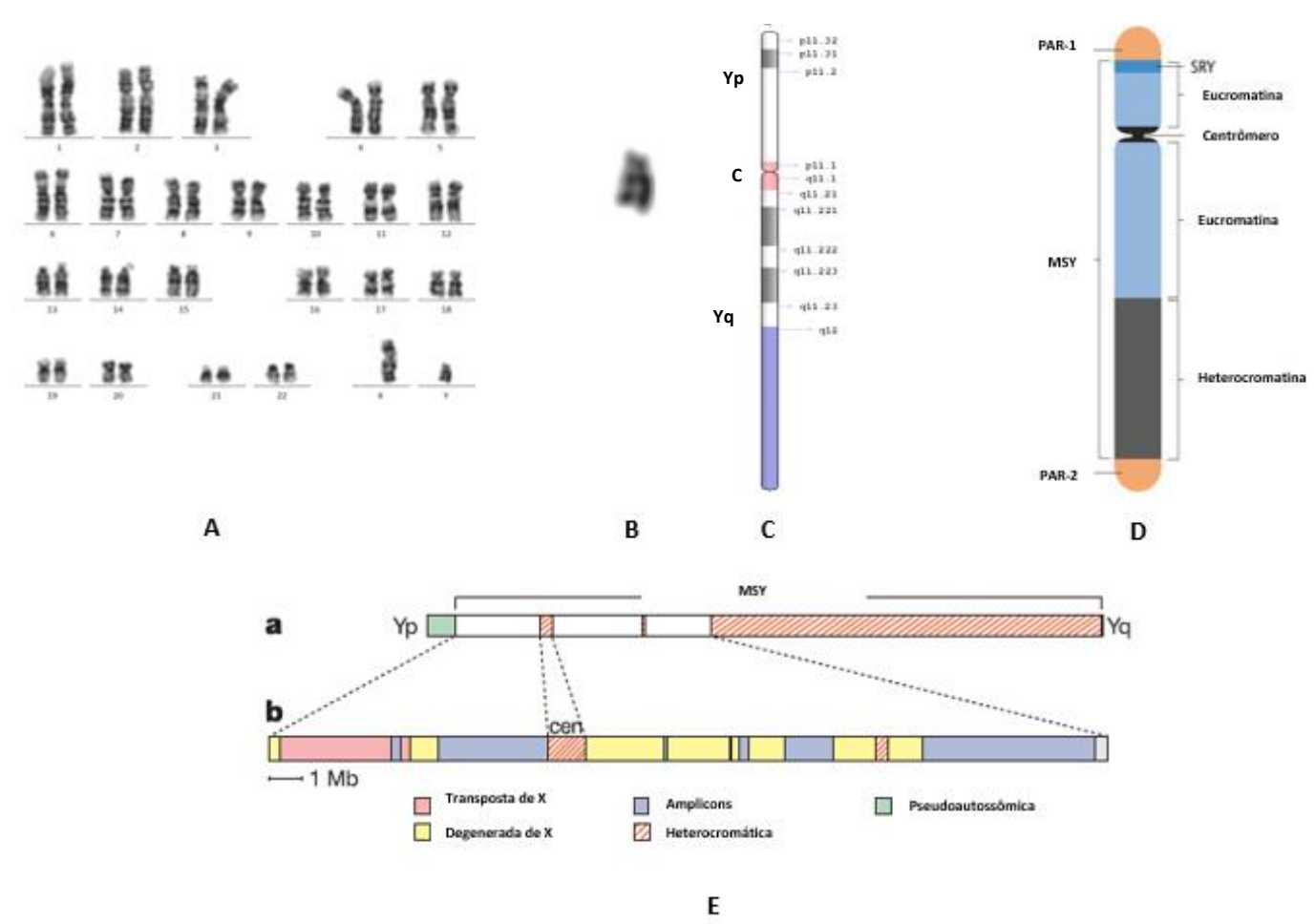

Na imagem A, observamos cariótipo humano normal para sexo masculino $(46, X Y)$ com ênfase no tamanho do cromossomo $\mathrm{Y}$ em relação aos outros cromossomos. Em B, aumento do cromossomo Y evidenciando sua classificação como acrocêntrico. Em C, ideograma do cromossomo Y com seu braço curto (Yp), centrômero (C) e braço longo (Yq). Em D, a estrutura desse cromossomo em relação as regiões pseudoautossômicas em suas extremidades e a região específica masculina (MSY) com as suas regiões de eucromatina e heterocromatina. Em E, detalhamento da região MSY evidenciando a distribuição das regiões transpostas e degeneradas do cromossomo X, além das regiões de amplicons (Adaptado de SKALETSKY, et al., 2003; BICHILE, et al., 2014).

Os amplicons são caracterizados por pares de sequências praticamente idênticas (> 99,9\% de homologia) organizadas em oito diferentes palíndromos e que apresentam importante significado clínico na fertilidade masculina, pois concentram os principais genes relacionados à espermatogênese. A presença dessas sequências repetidas com orientação invertida predispõe a dois mecanismos de recombinação com consequências opostas na fertilidade masculina:

a) Conversão gênica: definida como a transferência não recíproca de informação entre sequências duplicadas dentro do cromossomo. Este processo preservaria genes importantes para a fertilidade masculina, na medida em que preveniria o acúmulo gradual de mutações deletérias, através do tempo evolutivo, na ausência de permutação; 
b) Recombinação homóloga não-alélica (NAHR): essa mesma estrutura predispõe à deleção/duplicação do material genético entre sequências repetidas e apresenta potencial negativo na espermatogênese (KRAUSZ et al., 2014; KRAUSZ \& CASAMONTI, 2017) (Figura 7).

A relação entre anormalidades do cromossomo Y com infertilidade masculina foi descrita inicialmente por Tiepolo e Zuffardi em 1976. Nesse trabalho, esses autores utilizaram técnica citogenética para avaliar mais de mil homens inférteis e observaram que seis pacientes com azoospermia apresentavam deleção da região heterocromática e/ou eucromática de Yq. Esse trabalho foi crucial para a identificação e caracterização de um determinante genético, denominado de fator de azoospermia (AZF), envolvido com a espermatogênese.

Os avanços das técnicas de biologia molecular, mais precisamente o uso da técnica de reação em cadeia da polimerase utilizando marcadores genômicos específicos de locus (STS-PCR), levaram Vogt e colaboradores a descreverem, em 1996, três regiões distintas e consecutivas de AZF, a partir da região centromérica do cromossomo Y (AZFa, AZFb e $\mathrm{AZFc}$ ). Esse estudo possibilitou não só o melhor detalhamento, como também, a correlação entre achados clínicos dos homens inférteis e as microdeleções específicas dessa região. No fim da década de 90, a testagem molecular das microdeleções de AZF foi incluída na prática clínica, gerando dados mais precisos sobre seu impacto na fertilidade masculina (NAVARRO-COSTA et al., 2010; KRAUSZ et al., 2014) (Figura 7).

Atualmente, as microdeleções de AZF são consideradas as causas moleculares mais comuns de infertilidade no homem, sendo observadas em 10-15\% dos pacientes azoospérmicos e em 5-10\% dos com oligozoospermia grave, com possíveis variações geográficas e étnicas (YU et al., 2015; KRAUSZ \& CASAMONTI, 2017).

$\mathrm{Na}$ avaliação diagnóstica atual, cinco padrões de deleção na região de AZF são pesquisadas:

a) AZFa: formada por uma estrutura não repetitiva de $1100 \mathrm{~kb}$ que apresenta baixa frequência de deleção. Nessa região, dois genes de cópia única e com papel na fertilidade (USP9Y e DDX3Y) são descritos. Mais frequentemente são observadas deleção completa da região, porém deleções parciais envolvendo o gene USP9Y já foram descritas. USP9Y pertence a uma família de genes de deubiquitinação que atua 
na prevenção da degradação de proteínas e parece ter efeito regulador na espermatogênese. Pacientes com microdeleção parcial de AZFa apresentam variação fenotípica entre normospermia e hipoespermatogênese. O gene $D D X 3 Y$ ou $D B Y$ codifica uma RNA helicase necessária para a progressão mitótica e sobrevivência das células germinativas. É considerado o principal gene dessa região e sua perda de função leva ao fenótipo de aplasia de células germinativas (NETO et al., 2016; SONG et al.; 2016; KRAUSZ \& CASAMONTI, 2017);

Figura 7 - Mapeamento e estrutura palindrômica da Região AZF.
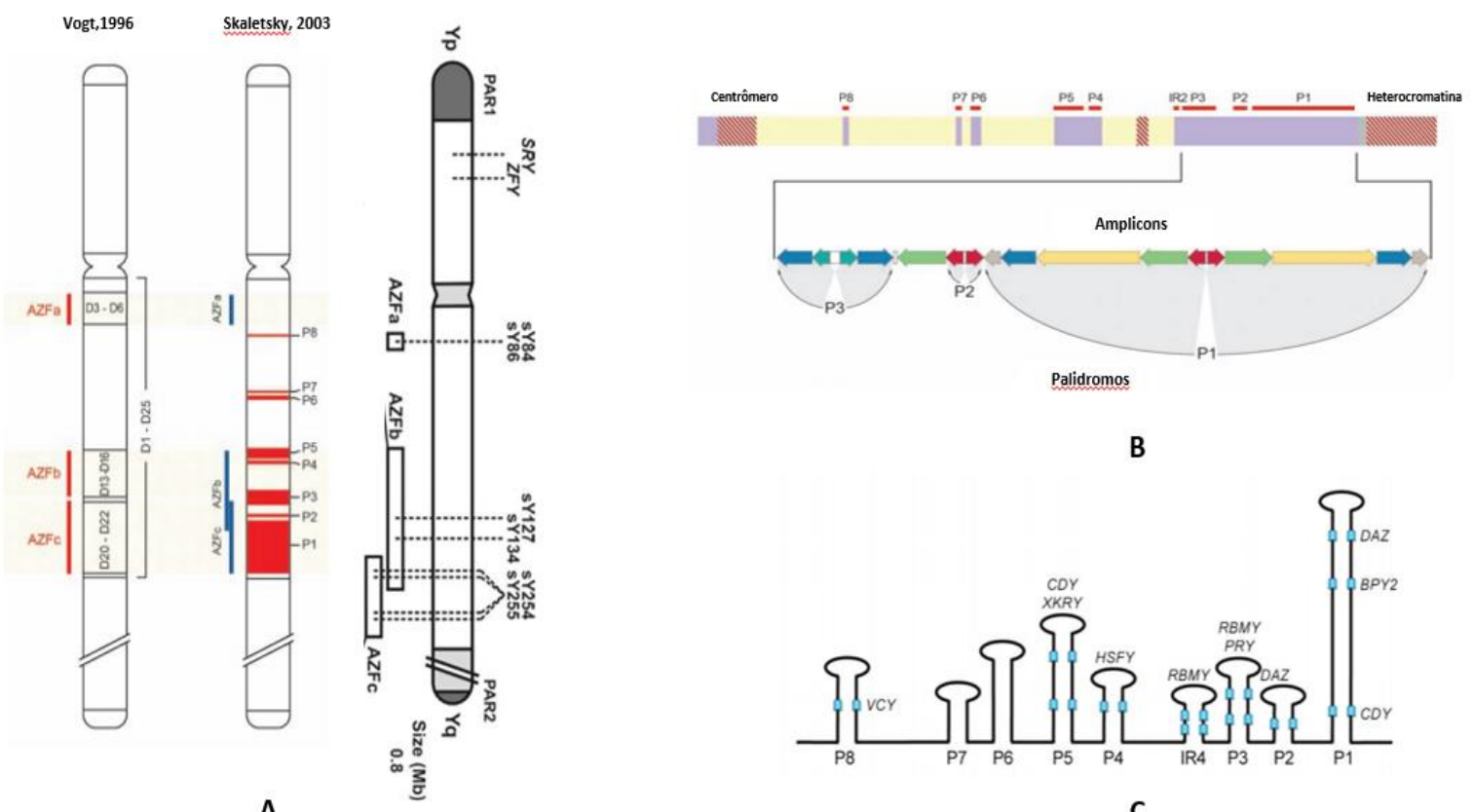

B

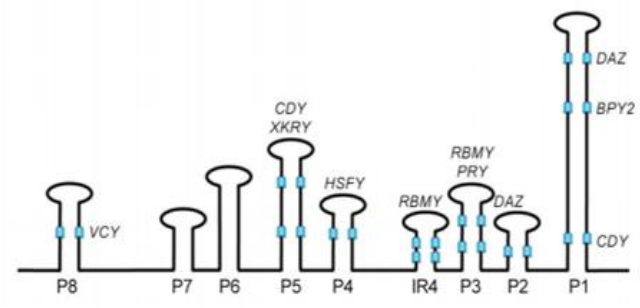

C

Na imagem A, observamos a evolução no mapeamento molecular da região de AZF. O modelo de Vogt e colaboradores propôs que o fator determinante da azoospermia estava dividido em três regiões consecutivas (AZFa, AZFb e AZFc). O modelo de Skaletsky e colaboradores definiu as regiões palindrômicas (P1-P8) e observou a sobreposição entras as regiões de AZFb e AZFc. Marcadores moleculares mais precisos (STS: sY84 e sY86 para AZFa; sY127 e sY134 para AZFb; sY254 e sY255 para AZFc) permitiram melhor delimitação dessa região e são utilizados, na atualidade, nos testes de rotina diagnóstica. Na imagem B, detalhamos a estrutura palindrômica característica da região de amplicons de MSY. No detalhe, os palíndromos P1-P3 evidenciam as sequencias repetidas com orientação invertida que podem levar à recombinação homóloga não alélica (NAHR), mecanismo mais comum associado com as microdeleções (imagem C) (Adaptado de SADEGHI-NEJAD \& FARROKHI, 2007; REPPING et al., 2002; KRAUSZ et al., 2014; SONG et al., 2016).

b) $\mathrm{AZFb}$ : formada por regiões repetitivas e não repetitivas que se estendem por cerca de 7Mb. Nessa região são encontrados genes de cópia única (EIF1AY, RPS4Y2 e KDM5D) envolvidos no controle epigenético e pós-transcricional e por genes de 
cópias múltiplas, como $R B M Y$ e $P R Y$, considerados os mais importantes dessa região. Pacientes com microdeleção dessa região apresentam azoospermia com parada de maturação ou aplasia de células germinativas (SONG et al.; 2016; KRAUSZ \& CASAMONTI, 2017);

c) AZFbc: representada pela deleção completa de AZFc e deleção quase completa de $\mathrm{AZFb}$. Está associada com a área de sobreposição de 1,5Mb entre essas duas regiões. É o terceiro padrão mais frequente e o fenótipo clínico assemelha-se à microdeleção de AZFb (FLANNIGAN \& SCHLEGEL, 2017);

d) $\mathrm{AZFc}(\mathrm{b} 2 / \mathrm{b} 4)$ : a região de AZFc estende-se por 4,5 Mb e contém genes de cópias múltiplas como BPY2, CDY, DAZ, CSPG4LY e GOLGAZLY. Constitui o padrão de microdeleção mais comum (60\%) e é observada em 2-5\% de homens oligospérmicos e 5-10\% em azoospérmicos. Os pacientes portadores de microdeleção nessa região apresentam diferentes fenótipos, variando da normospermia à azoospermia não obstrutiva com diferentes padrões histológicos (NETO et al., 2016; SONG et al., 2016; TOURNAYE et al. 2016; FLANNIGAN \& SCHLEGEL, 2017);

e) Rearranjos de AZFc (gr/gr; b2/b3 e b1/b3): são rearranjos raros que têm efeitos controversos na espermatogênese, já que a associação com a redução de fertilidade masculina varia entre as diferentes populações. A dosagem gênica parece ser o mecanismo associado com essas diferenças. As deleções $g r / g r$, por exemplo, estão associadas com redução de 2 - 2,5 vezes da fertilidade na população mediterrânea. Pacientes portadores dessa microdeleção apresentam diferentes fenótipos entre a normalidade e a azoospermia (KRAUSZ \& CASAMONTI, 2017) (Figura 8).

A avaliação molecular das microdeleções de AZF tem papel não só diagnóstico, como também prognóstico e preventivo. Pacientes com microdeleção completa de AZFa e $\mathrm{AZFb}$ não são candidatos à extração espermática testicular (TESE), pois apresentam fenótipo grave caracterizado por azoospermia não obstrutiva decorrente de aplasia de células germinativas ou parada de maturação espermática. Os pacientes com microdeleção de AZFc têm chance de $50 \%$ de recuperação espermática pela TESE e apresentam potencial de redução da concentração espermática com o passar do tempo, sendo indicado, dessa forma, criopreservação. Todos os pacientes com microdeleção de AZF devem receber aconselhamento genético para auxílio na compreensão do impacto genético e na decisão informada sobre possíveis técnicas reprodutivas (KRAUSZ \& CASAMONTI, 2017). 
Figura 8 - Correlação genótipo-fenótipo das microdeleções do cromossomo Y.

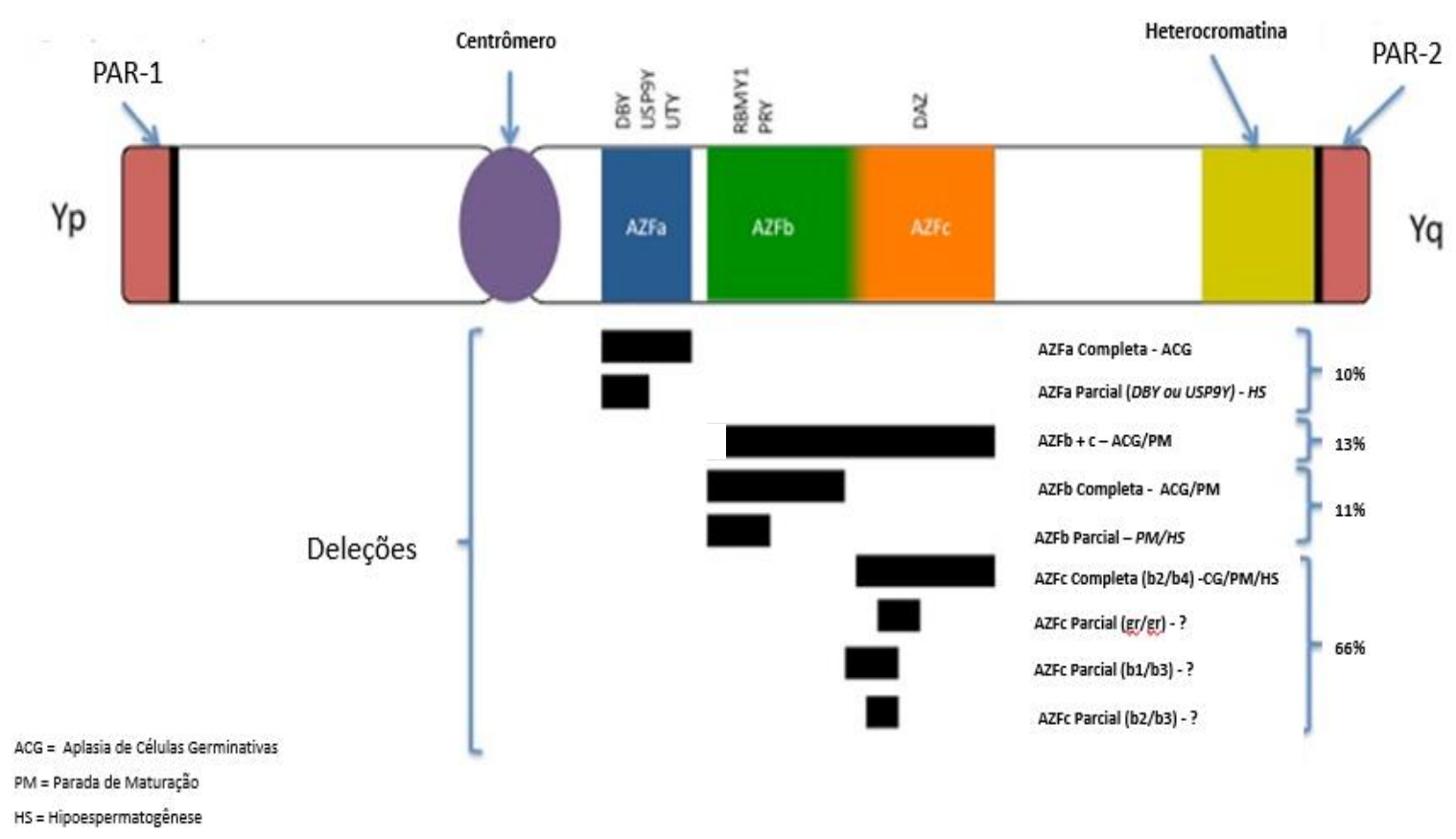

A figura demonstra as três principais regiões de AZF localizadas no braço longo do cromossomo Y. Essas regiões estão representadas por diferentes colorações. Acima, observamos os principais genes localizados em cada região e abaixo, os padrões de microdeleção com seus tamanhos relativos (barras pretas), alteração histológica e frequência observada na população infértil (Adaptado de NETO et al., 2016).

\subsection{Mutações de Ponto em Genes Autossômicos e Ligados ao X}

As alterações cromossômicas e as microdeleções de AZF representam a quase totalidade dos fatores genéticos que reconhecidamente alteram a função testicular. As mutações de ponto, que podem alterar tanto a concentração (alterações quantitativas) como a motilidade e a morfologia espermática (alterações qualitativas) têm sido reavaliadas por novas tecnologias para a compreensão do seu verdadeiro impacto sobre essa característica (RAY et al., 2017).

Diferentes abordagens na identificação de genes candidatos à infertilidade masculina, tais como: modelos animais, estudos de associação (GWAS), relatos de casos e estudos de caso-controle que comparam populações heterogêneas de homens inférteis com controles férteis, já foram utilizadas e auxiliaram na determinação de algumas mutações patogênicas que alteram processos fundamentais na produção espermática (CARRELL et al., 2016). 
Dentre os genes que regulam a concentração espermática de forma direta ou indireta, estão:

a) DMRT1, localizado em 9p24.3, codifica uma proteína com domínio dedo de zinco, expresso no tecido testicular, mais precisamente nas células de Sertoli e espermatogônias. Tem papel na determinação e diferenciação testicular e promove a proliferação das células germinativas (TEWES et al., 2014);

b) SAM 68 tem papel fundamental na regulação transcricional e pós-transcricional da expressão gênica durante a diferenciação das células germinativas humanas. (LI et al., 2014);

c) PGAM1 codifica a enzima fosfoglicerato mutase, uma enzima da via glicolítica, que pode alterar a proliferação celular, apoptose e migração de células germinativas (ZHANG et al., 2015);

d) $S Y C P 3$, localizado em 12q23.2, codifica uma proteína componente do complexo sinaptonêmico. Durante o processo de meiose, os cromossomos homólogos pareiam e trocam partes de seus segmentos, garantido aumento da variabilidade genética entre os gametas produzidos. Mulheres com mutação nesse gene apresentam abortamento de repetição, enquanto que os homens apresentam azoospermia não obstrutiva secundária à parada de maturação de células germinativas (MIYAMOTO et al., 2017);

e) KLHL10, localizado em 17q21, descrito, inicialmente, em pacientes oligozoospérmicos e associado com parada de maturação espermática (MIYAMOTO et al., 2017).

Estudos em famílias consanguíneas levaram à identificação de vários genes com padrão autossômico recessivo. Dentre esses genes podem ser citados ZMYND15, TAF4B, SYCE1, MCM8, PLCZ1, TEX14, TEX15, CFAP43, CFAP44, BRDT, MEIOB, TDRD9 e NPAS2 (ARAFAT et al., 2017; MITCHELL et al., 2017).

As principais alterações qualitativas que envolvem a morfologia espermática (teratozoospermia) e respectiva alteração gênica, são:

a) Macrozoospermia ou espermatozoides multiflagelados macrocéfalos: causada por mutação no gene $A U R K C$ (Aurora quinase do tipo C). Esse gene é responsável pela síntese de um dos componentes de um complexo proteico que se liga aos centrômeros e regula a segregação e citocinese. Mutações nesse gene 
impedem a segregação correta dos cromossomos resultando em espermatozoides tetraploides;

b) Globozoospermia: causada por mutações nos genes SPATA16, PICK1, DPY19L2 e $Z P B P 1$, responsáveis pela formação do acrossoma espermático. Espermatozoides sem essa estrutura são incapazes de fertilização devido à inabilidade de adesão e penetração da zona pelúcida;

c) Espermatozoides acéfalos: causados por mutação em SUN5 e SPATA6, responsáveis por codificar proteínas do citoesqueleto que fazem conexão entre as estruturas dos espermatozoides (TOURNAYE et al., 2016).

As mutações que levam à alteração da motilidade espermática (astenozoospermia) ocorrem em genes que regulam tanto a montagem como a estrutura do flagelo (DNAH1, SEPTIN12), assim como aqueles responsáveis pelo seu funcionamento correto (canais iônicos) (CATSPER, SLC26A8) (DAM et al., 2007; LIU et al., 2010; VISSER et al., 2011; RAY et al., 2017).

Muitos genes localizados no cromossomo X têm expressão testicular e regulam a diferenciação sexual e gonadal, além de participarem da espermatogênese. Dentre os mais conhecidos estão:

a) Gene do Receptor de andrógeno $(A R)$ está associado com amplo espectro fenotípico de insensibilidade androgênica que varia desde fenótipo feminino (Síndrome de Insensibilidade Androgênica Completa) até homens fenotipicamente normais com graus variáveis de ginecomastia, hipospádia ou comprometimento espermatogênico (Síndrome de Insensibilidade Androgênica Leve). Mutação no gene $A R$ é uma causa rara de infertilidade masculina isolada;

b) TEX11, localizado em Xq13.2, codifica uma proteína crítica para o reparo de DNA de fita dupla e importante para a recombinação meiótica nas células germinativas testiculares. Pacientes com mutações nesse gene apresentam parada de maturação espermática;

c) RHOX constitui uma família gênica representada no cromossomo X pelos genes RHOXF1, RHOXF2 e RHOXF2B que são seletivamente expressos em ovócitos e células germinativas masculinas. Pacientes com mutações nesses genes clinicamente apresentam oligozoospermia grave; 
d) USP26 não tem sua função ainda totalmente compreendida, mas parece regular a espermatogênese em associação com o receptor de andrógeno;

e) TAF7L é essencial para a manutenção da espermatogênese. Pacientes portadores de mutação nesse gene apresentaram tanto alteração quantitativa como da motilidade espermática (RÖPKE \& TÜTTELMANN, 2017).

\subsection{Alterações Epigenéticas}

Modificações epigenéticas são definidas como alterações no padrão de expressão gênica sem alterar a sequência de DNA. Os mecanismos epigenéticos envolvidos na regulação da expressão gênica incluem a metilação do DNA, modificações de histonas, remodelamento da cromatina e expressão de microRNAs. Esses mecanismos podem variar entre diferentes tipos celulares, estágios de desenvolvimento, tecidos, órgãos, sexos e espécies. No caso do tecido testicular e, mais precisamente, no genoma espermático, ocorre um mecanismo epigenético específico denominado de protaminação. Nesta etapa específica da espermiogênese, $80-85 \%$ das histonas são substituídas por proteínas denominadas de protaminas, resultando em um pacote de cromatina denominado de toroide (HAMMOUD et al., 2011; CUI et al., 2016; NETO et al., 2016) (Figura 9).

O papel entre metilação do DNA e infertilidade masculina ainda é controverso, porém já é reconhecido que a reprogramação epigenética é um evento relevante na espermatogênese. Existem dois estágios de reprogramação epigenética, uma durante o desenvolvimento gonadal e outro na vida adulta, estabelecendo o padrão de hipometilação do DNA na linhagem germinativa masculina. A alteração desse padrão de metilação tem sido associada à redução da qualidade espermática e à diminuição da fecundidade (CUI et al., 2016; NETO et al., 2016) (Figura 9).

A diferenciação celular está associada à remodelação dinâmica da cromatina no estabelecimento de suas marcas epigenômicas específicas. Mecanismos de modificação póstraducionais tais como a metilação, acetilação, fosforilação e ubiquitinação de histonas auxiliam nessa modulação da expressão gênica. Em modelo animal, foi observado que uma histona de expressão específica do testículo, H3t, é essencial nos estágios iniciais da espermatogênese, permitindo que as células germinativas entrem em meiose. Camundongos com deficiência dessa histona são azoospérmicos devido à perda de células germinativas (NETO et al., 2016; UEDA et al., 2017) (Figura 9). 
MicroRNAs (miRNAs) compõem uma nova classe de reguladores póstranscricionais constituídos por moléculas de RNA de fita simples, de 19-25 nucleotídeos e não codificantes de proteínas. Essas moléculas modulam a expressão de vários genes codificantes de proteínas por diversos mecanismos, sendo os mais conhecidos aqueles que atuam pela complementaridade com o RNA mensageiro-alvo levando à inibição traducional ou degradação desse RNA mensageiro. Os miRNAs têm expressão espacial e temporal em diferentes tipos celulares durante a espermatogênese e espermiogênese, porém o papel e os mecanismos subjacentes a essa regulação ainda não são totalmente compreendidos (WANG et al., 2011; NETO et al., 2016; FLANNIGAN \& SCHLEGEL, 2017) (Figura 9).

Os exemplos citados anteriormente reforçam o entendimento de que a infertilidade masculina é um fenótipo complexo no qual há a interação de diferentes fatores genéticos, epigenéticos e ambientais e que mesmo com a investigação apropriada, cerca de 30-50\% dos pacientes com falha espermatogênica primária permanecem sem etiologia esclarecida, caracterizando o grupo de infertilidade masculina idiopática (CARRELL et al., 2016).

Baseado na ideia de que cerca de 1500 - 2000 genes participam da regulação da espermatogênese, diferentes grupos de pesquisa buscaram estratégias para encontrar marcadores moleculares implicados com infertilidade. Uma dessas abordagens foi o uso do sequenciamento de genes envolvidos na espermatogênese, identificados por modelo animal knockout, utilizando a técnica de Sanger. Essa análise envolvia a identificação de polimorfismos de nucleotídeo único (SNP) que ocorriam mais frequentemente no grupo de homens inférteis do que no controle. Os resultados foram frustrantes, pois não houve concordância entres os diferentes grupos de pesquisa devido ao tamanho das amostras e a diferenças populacionais. O desafio na caracterização das bases genéticas da infertilidade masculina é resultante da complexidade do processo da espermatogênese que requer a ação conjunta de milhares de genes sob controle de elementos regulatórios ainda não totalmente compreendidos (ASTON, 2014).

Avanços tecnológicos estimularam a pesquisa de genes envolvidos na infertilidade masculina utilizando técnicas de investigação genômica em larga escala, tais como: hibridação genômica comparativa em microarranjo (aCGH), microarranjos associando análise de variantes do número de cópias (CNVs) e SNPs e mais recentemente, as técnicas de sequenciamento de nova geração (NGS) (TÜTTELMANN et al., 2011; KRAUZ et al., 2015; MITCHELL et al., 2017). 
Figura 9 - Alterações epigenéticas na infertilidade masculina
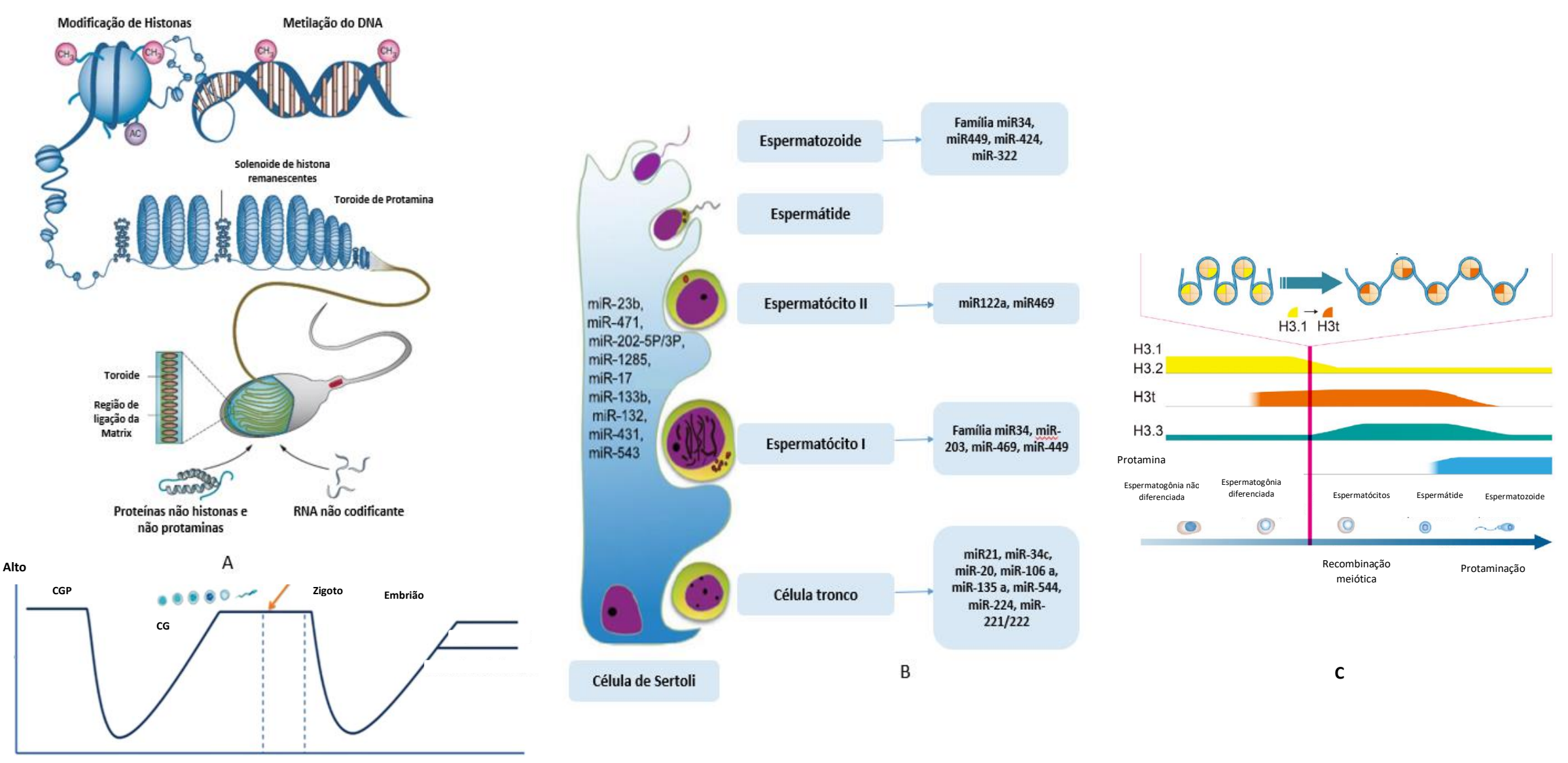

Baixo

A figura $\mathbf{A}$ resume os principais mecanismos epigenéticos que levam uma célula germinativa a se tornar uma célula reprodutiva especializada denominada de espermatozoide. Abaixo, um gráfico que evidencia a reprogramação epigenética de células germinativas em modelo animal. Na idade adulta, as células germinativas (CG) iniciais estão hipometiladas assim como no período embrionário. A remetilacão inicia-se na fase de pró-espermatogônia. Em B observamos a expressão têmporo-espacial de miRNAs nas diferentes células que formam o túbulo seminífero. Em C , observamos o papel da histona H3t na diferenciação de espermatogônia para espermatócito em modelo animal. Essa histona leva à abertura da cromatina que permitirá o ingresso dessa célula na divisão meiótica. (Adaptado de SCHAGDARSURENGIN et al., 2012; CUI et al., 2016 CHEN et al., 2017; UEDA et al., 2017). 


\subsection{Genômica na Infertilidade Masculina Idiopática}

\subsubsection{Genoma humano e suas variantes}

O genoma humano apresenta um espectro de diferenças que varia de uma alteração em um único par de base até rearranjos cromossômicos maiores. Antes das tecnologias de sequenciamento, as diferenças observadas na nossa composição genética eram resultantes das alterações numéricas e rearranjos estruturais cromossômicos maiores que $5 \mathrm{Mb}$, observados ao microscópio. Com o avanço das técnicas moleculares, principalmente sequenciamento, alterações menores e mais abundantes no nosso genoma foram descritas (FEUK et al., 2006; ALKAN et al., 2011; MICHAELSON, 2017).

As variantes estruturais são definidas como alterações genômicas que envolvem sequências de DNA maiores que 50pb e que são genotipadas pela avaliação de três principais características: estrutura, conteúdo e número de cópias. Podem ser subclassificadas em microscópicas (translocações, grandes deleções ou duplicações e as inversões) ou submicroscópicas (variantes de número de cópias (CNVs), elementos móveis, duplicações em tandem e indels) (FEUK et al., 2006; ALKAN et al., 2011; MICHAELSON, 2017).

As CNVs correspondem a um subtipo de variante estrutural cromossômica de tamanho superior a $1 \mathrm{~kb}$ caracterizadas por perdas (deleções), ganhos (duplicações) ou inserção de material genético quando comparado a um genoma de referência. Essas variantes são detectadas em cerca de $15 \%$ do genoma humano e são consideradas fontes primárias de variabilidade interindividual. Dessa forma, a maioria é benigna. Porém, algumas dessas alterações estruturais podem levar à repercussão clínica por uma variedade de processos patogenéticos que incluem a alteração da dosagem gênica, a disrupção ou fusão de genes nas regiões do ponto de quebra, deleção de elementos regulatórios, alteração do padrão de expressão gênica pelo efeito posicional ou desmascarando mutações recessivas (EGGERS, et al., 2015; NOWAKOWSKA, 2017; HAREL \& LUPSKI, 2017).

A avaliação da patogenicidade de uma CNV é ainda considerada desafiadora. Alguns fatores estão relacionados com maior risco de gravidade, tais como: 
a) Origem: variantes detectadas exclusivamente em indivíduos portadores de uma determinada característica tem associação com efeitos deletérios maior do que aquelas que são compartilhadas entre seus familiares e/ou indivíduos da população;

b) Tamanho: está relacionado com a quantidade de diferentes genes ou o número de cópias de um mesmo gene numa determinada região. Estudos de caso-controle têm mostrado que CNVs maiores são mais frequentes nas populações em estudo do que nos controles. Na população com deficiência intelectual, por exemplo, CNVs maiores que 500kb são encontradas em 25\% desses indivíduos, enquanto que na população sem alteração cognitiva, essa frequência reduz para $8 \%$. Em geral, $5-10 \%$ dos indivíduos apresentam CNVs >500kb, enquanto que 1-2\% apresentam CNVs >1Mb. Considera-se que o tamanho de uma CNV é inversamente proporcional a sua frequência;

c) Conteúdo genômico: classicamente as variantes com maior impacto no fenótipo são aquelas que incluem genes codificantes, porém regiões com elementos repetitivos ou pseudogenes também podem apresentar significância. $\mathrm{O}$ impacto do conteúdo gênico deve ser cuidadosamente analisado. Por exemplo: genes associados com fenótipo clínico devido à haploinsuficiência ou mutações por perda de função, não devem ter fenótipo associado com CNV do tipo ganho envolvendo esse gene;

d) Frequência: variantes raras são encontradas com uma frequência menor que $1 \%$ na população ou apresentam região de sobreposição menor que $50 \%$ de uma CNV comum. Variantes raras e comuns podem ser encontradas tanto na população normal como em pacientes com algum fenótipo clínico, porém as CNVs raras concentram maior risco de patogenicidade. Em média, são encontradas de 3-7 CNVs raras por genoma;

e) Avaliação em bancos de dados: A análise das variantes em bancos de dados gerais e específicos também fornece importantes informações clínicas. A interpretação está baseada em diferentes tipos de bancos e informações. Como exemplo de banco de dados do tipo geral estão o DGV (Database of Genomic Variants), considerado como o catálogo humano de CNVs e de variantes estruturais e o Projeto 1000 Genomes, baseado em informações oriundas do sequenciamento completo de genomas. Os bancos de dados do tipo específico reportam variações 
genômicas descritas em determinados fenótipos clínicos. Como exemplos, podem ser citados o DECHIPHER (DatabasE of Chromosomal Imbalance and Phenothype in Human using Ensemble Resources), o ISCA (International Standards for Cytogenomic Arrays) e o ECARUCA (European Cytogeneticits Association Register of Unbalanced Chromosome Aberration). Existem ainda bancos de dados produzidos por alguns laboratórios ou pesquisas que podem fornecer informações relevantes para fenótipos específicos (LEE, et al., 2007; NOWAKOWSKA, 2017; HAREL \& LUPSKI, 2017).

Existem ainda CNVs classificadas como VUS (do inglês, variants of unknown clinical significance) cuja patogenicidade ainda é desconhecida devido à ausência de descrição em indivíduos normais e à escassez de informação quanto ao seu significado clínico (BOGGULA et al., 2015).

As variantes de nucleotídeo único (SNV) são consideradas as menores variantes genéticas e podem ocorrer em regiões codificantes ou não. As localizadas em região codificante podem alterar a leitura do código genético, enquanto as localizadas em região não codificante podem alterar a afinidade de ligação de proteínas específicas ao DNA, tais como os fatores de transcrição. Além disso, podem alterar propriedades epigenéticas da cromatina (MICHAELSON, 2017).

Os SNPs são exemplos de variantes de nucleotídeo único e constituem uma das classes de variantes mais comuns no genoma humano. São encontrados, em média, um polimorfismo desta natureza a cada $1.000 \mathrm{pb}$. Aproximadamente 70\% dos SNPs estão localizados nos introns e a grande maioria ainda não foi documentada em bancos de dados públicos. A patogênese dessas variantes está correlacionada com a possível alteração de splicing, impactando na expressão gênica (WANG et al., 2012).

\subsubsection{As Plataformas de Análise Genômica}

A técnica de hibridação genômica comparativa em microarranjo (aCGH) é baseada numa reação de hibridação entre duas amostras desnaturadas de DNA genômico (teste e referência) marcadas com corantes fluorescentes distintos e misturadas de forma equimolar. Essas amostras irão competir pela hibridação com sondas fixadas e organizadas na superfície de uma lâmina. Após as etapas de lavagem e secagem, a marcação fluorescente é detectada por um scanner de alta resolução e o sinal emitido a partir de cada ponto (spot) do arranjo 
será analisado por um programa que converterá os sinais em dados de bioinformática. Alterações na proporção dos dois corantes fluorescentes indicam uma quantidade diferente de material genético entre a amostra teste e a de referência podendo, dessa forma, evidenciar alterações no número de cópias de segmentos de DNA (LICHTER et al., 2000; ROSENFELD \& PATEL, 2017; SZCZALUBA \& DEMKOW, 2017) (Figura 10).

A resolução de um arranjo é determinada tanto pelo tamanho da sonda quanto pela distância genômica entre as sondas de DNA. As primeiras plataformas de aCGH utilizaram sondas obtidas de clones de cromossomos artificiais de bactérias (BACs) imobilizados em suporte de vidro de forma ordenada. Esses clones possuíam comprimento variando entre 80.000 - 200.000 mil pares de bases e, por serem menores que os cromossomos metafásicos em várias ordens de magnitude, permitiram uma resolução maior que o $\mathrm{CGH}$ tradicional. Com o passar do tempo, pequenos fragmentos de DNA complementar (cDNA), produtos de PCR e oligonucleotídeos passaram a ser utilizados como sondas (FEUK et al., 2006).

Figura 10 - Representação da técnica de Hibridação Genômica Comparativa em microarranjo (aCGH)

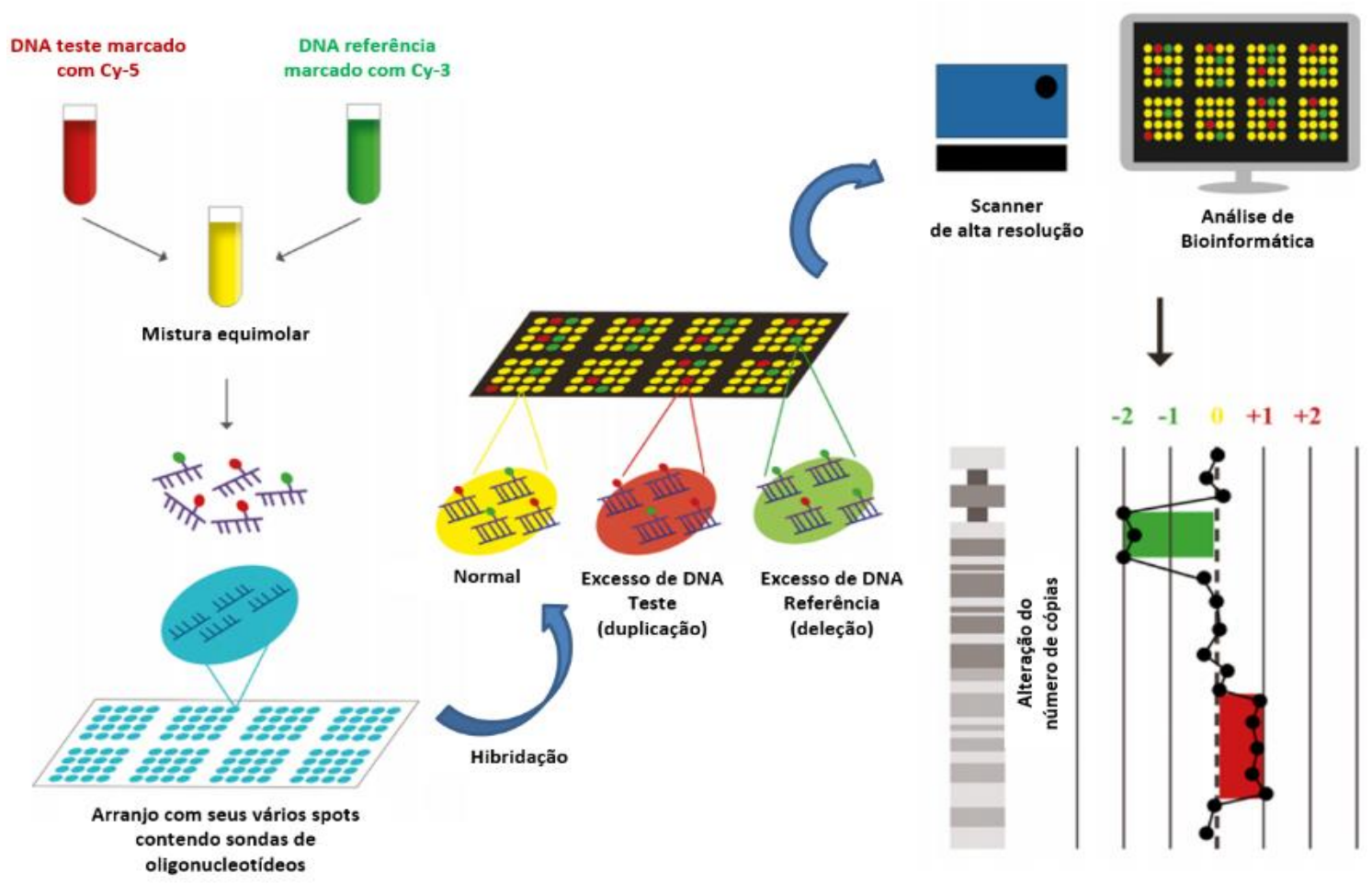

A figura representa as principais etapas da técnica de hibridação genômica em microarranjo. Quantidades equimolares de DNA genômico teste e de referência são hibridados em uma lâmina contendo sondas de oligonucleotídeos. Após lavagem e secagem, a lâmina é analisada por um scanner de alta resolução e os sinais de marcação fluorescente são convertidos em dados de bioinformática que resultarão na análise do padrão de alteração do número de cópias (Adaptado de COLAIANNI et al., 2016). 
Várias plataformas estão disponíveis atualmente no mercado e apresentam diferenças na resolução (número, tamanho e espaçamento entre as sondas) e na cobertura genômica (sensibilidade de hibridação e na razão sinal/ruído de cada sonda) (ALKAN et al., 2011).

O microarranjo de SNP difere do anterior, na medida em que, a amostra do paciente é hibridada separadamente da amostra controle e são pesquisadas regiões de perda de heterozigosidade (LOH) por genotipagem dos polimorfismos de nucleotídeo único (SNP). As LOH são trechos longos do genoma marcados por alelos consecutivos em homozigose e que podem refletir regiões idênticas por descendência, seja por endogamia, consanguinidade ou, ainda, dissomia uniparental. Essas alterações podem influenciar fenótipos complexos pela expressão de alelos recessivos ou genes imprintados (D'AMOURS et al., 2014; WANG et al., 2015).

Mais recentemente, foram lançadas plataformas mais robustas que permitem a avaliação genômica através da análise de uma combinação de sondas para a detecção de CNVs e SNPs em um único experimento $(\mathrm{aCGH}+\mathrm{SNP})$, permitindo a análise de ganhos e perdas de material genético, assim como polimorfismos e LOHs (WANG et al., 2015).

A técnica de hibridação genômica comparativa apresenta vantagem na avaliação de fenótipos complexos, como a infertilidade masculina, uma vez que não apresenta viés de seleção, isto é, não é gene direcionada. A resolução das plataformas é considerada um fator limitante, já que pequenas deleções/duplicações ou mesmo mutações de ponto podem não ser detectadas por essa técnica (STOUFFS et al., 2012).

Nos últimos anos, vários trabalhos com diferentes plataformas de hibridação genômica foram publicados na área de infertilidade masculina. No início, a avaliação genômica foi utilizada na investigação de grupos heterogêneos de homens inférteis, sem a utilização de critérios clínicos para definição de grupos de estudo. Em seguida, foram criadas plataformas voltadas para análise específica de determinados cromossomos, como o X e Y e somente mais recentemente, é que trabalhos com grupos específicos e criteriosos têm sido utilizados, contribuindo na identificação de novos marcadores genéticos envolvidos com fertilidade masculina (OSBORNE et al., 2007; TÜTTELMANN et al., 2011; KRAUSZ et al., 2012; FRUHMESSER et al., 2013; CHIANESE et al., 2014; EGGERS et al., 2015; HALDER et al., 2017; SHEN et al., 2017). 


\section{JUSTIFICATIVA}

É inútil falar de curas ou pensar em remédios até termos considerado as causas [...] as curas podem ser imperfeitas e não servir para nada enquanto as causas não tiverem sido pesquisadas.

Robert Burton 


\section{JUSTIFICATIVA}

A infertilidade conjugal é uma doença do aparelho reprodutivo que afeta uma parcela significativa da população mundial e apresenta repercussões clínicas e psicológicas graves. O fator masculino é responsável por metade dos casos e ainda é considerado uma condição heterogênea, resultante da interação de diversos fatores, nos quais a etiologia genética prepondera. Mesmo com a padronização da avaliação diagnóstica ao redor do mundo e com a disponibilidade da realização de diferentes técnicas diagnósticas, metade dos pacientes avaliados permanecem sem diagnóstico preciso, caracterizando a infertilidade masculina idiopática.

O Serviço de Genética Médica do Hospital das Clínicas da Faculdade de Medicina de Ribeirão Preto da Universidade de São Paulo (HCFMRP/USP) tem contribuído com a Divisão de Urologia do Departamento de Cirurgia e Anatomia, bem como com o Departamento de Ginecologia e Obstetrícia, na investigação diagnóstica da infertilidade masculina, auxiliando na avaliação genético-clínica dos pacientes encaminhados e realizando exames complementares, como, por exemplo, o exame citogenético. Esse é um diferencial frente a outros grupos de pesquisa que estudam infertilidade.

O Laboratório de Citogenética Molecular Humana da Faculdade de Medicina de Ribeirão Preto, onde este projeto foi desenvolvido, também contribuiu para a padronização de técnicas utilizadas na investigação molecular de infertilidade masculina, como a PCR multiplex, capaz de identificar microdeleções no braço longo do cromossomo Y. Essa técnica foi incorporada à rotina diagnóstica, permitindo que nossos pacientes seguissem os protocolos internacionais de investigação. Além dela, a técnica de Hibridação Genômica Comparativa em microarranjo, utilizando uma plataforma robusta, tem possibilitado a identificação de alterações genômicas potencialmente associadas com infertilidade.

Considerando que são escassos os estudos disponíveis na literatura associando essa ferramenta de avaliação genômica com a infertilidade masculina, nossa proposta foi a de realizar a caracterização genômica em grupo específico e bem categorizado de homens com infertilidade masculina, decorrente de falência espermatogênica primária, com o intuito de identificar possíveis alterações genômicas relacionadas com azoospermia não obstrutiva idiopática. 


\section{HIPÓTIEST}

Se você sabe a pergunta, sabe a metade.

Herb Boyer 


\section{HIPÓTESE}

Nossa hipótese é que pacientes com infertilidade masculina por azoospermia não obstrutiva idiopática apresentam diferenças no número e/ou padrão de variantes genômicas, quando comparadas ao grupo controle, e que essas podem estar relacionadas à etiologia desse fenótipo complexo. 


\section{OBJETIVOS}

"Há mais imaginação no mundo do que se poderia pensar". Andrew Solomon 


\section{OBJETIVOS}

\subsection{Objetivo Geral}

Realizar a caracterização genômica de pacientes com infertilidade masculina por azoospermia não obstrutiva idiopática visando a identificação de alterações genômicas possivelmente relacionadas a esse fenótipo, utilizando a técnica de hibridação genômica comparativa.

\subsection{Objetivos Específicos}

4.1.1 Descrever as principais alterações genômicas (CNVs e LOHs) que podem estar associadas ao fenótipo de infertilidade masculina por azoospermia não obstrutiva idiopática;

4.1.2 Analisar a distribuição, a relevância e o padrão das alterações genômicas observadas entre o grupo de pacientes com azoospermia não obstrutiva idiopática e o grupo controle; 


\section{$\mathcal{M A \mathcal { T }} \mathcal{R} I \mathcal{A} \mathcal{L} e$ MÉTODOS}

“[...] ouvem-se ocasionalmente palavras e frases médicas, porém o dialeto dos laboratórios tem pouca semelhança com a medicina. É como viajar a um país vizinho onde os maneirismos são parecidos, mas se fala outra língua”.

Siddhartha Mukherjee 


\section{MATERIAL e MÉTODOS}

\subsection{Material}

\subsubsection{Considerações Éticas}

Todos os indivíduos que foram convidados e desejaram participar da pesquisa, seja como grupo amostral ou controle, assinaram o Termo de Consentimento Livre e Esclarecido (TCLE) (APÊNDICE A) referente ao Projeto (3537/2013) aprovado pelo Comitê de Ética em Pesquisa do HCFMRP/USP (ANEXO A).

\subsubsection{Seleção dos Pacientes}

Este projeto foi realizado no Laboratório de Citogenética Molecular Humana do Departamento de Genética da Faculdade de Medicina de Ribeirão Preto da Universidade de São Paulo (FMRP/USP) em colaboração com o Serviço de Genética Médica, o Laboratório de Citogenética, a Divisão de Urologia do Departamento de Cirurgia e Anatomia e o Departamento de Ginecologia e Obstetrícia do Hospital das Clínicas da FMRP/USP (HCFMRP/USP).

Os pacientes em investigação por infertilidade masculina foram avaliados inicialmente no ambulatório de infertilidade conjugal (AIFE), uma parceria entre a Divisão de Urologia e o Departamento de Ginecologia e Obstetrícia do HCFMRP/USP. Após avaliação clínica e complementar extensiva, apenas os pacientes com causas testiculares e pós-testiculares foram encaminhados ao ambulatório de Genética Médica (GEN-3) para avaliação clínica complementar, realização de exame citogenético e molecular e análise dos critérios de inclusão e exclusão deste estudo.

Somente os pacientes com azoospermia não obstrutiva idiopática, que seguiam os critérios de inclusão e exclusão desse estudo, foram submetidos à analise genômica.

\subsubsection{Critérios de Inclusão}

a) Idade inferior a 45 anos;

b) Paciente ter realizado exames laboratoriais essenciais na investigação de infertilidade por fator masculino, tais como: 
- Pelo menos duas avaliações seminais, com intervalo mínimo de 90 dias entre as coletas, evidenciando azoospermia não obstrutiva, segundo os critérios da OMS em 2010;

- Exame citogenético com exclusão de mosaicismo cromossômico pela contagem de pelo menos 50 metáfases. Essa rotina é capaz de identificar mosaicismo numa porcentagem superior a $6 \%$ e com intervalo de confiança de $95 \%$ (HOOK, 1977);

- Investigação molecular para microdeleções da região de AZF por PCR multiplex.

\subsubsection{Critérios de Exclusão}

Qualquer característica clínica ou laboratorial reconhecidamente associada ao fenótipo infertilidade masculina (Tabela 1).

\subsubsection{Definição do Grupo Amostral}

Inicialmente, foram avaliados 101 homens com diagnóstico de infertilidade conjugal por fator masculino após a exclusão das causas pré-testiculares. Desse grupo inicial, 70 pacientes com oligozoospermia e 3 com azoospermia obstrutiva foram excluídos. Dos 28 pacientes com azoospermia não obstrutiva, 3 indivíduos foram excluídos por apresentarem histórico de tratamento cirúrgico em região genital (orquidopexia). Além disso, mais 3 indivíduos não prosseguiram na avaliação pois foram diagnosticados, respectivamente, com síndrome de insensibilidade androgênica parcial (SIPA), doença multissistêmica em investigação cursando com azoospermia não-obstrutiva e elevação isolada de gonadotrofina (FSH) de etiologia não definida. Após a realização de exames genéticos complementares, foram excluídos 5 pacientes com alguma anormalidade cromossômica (3 pacientes foram diagnosticados com Síndrome de Klinefelter e 2 com heteromorfismo de cromatina) e um outro paciente foi excluído por apresentar microdeleção completa (b2/b4) na região de AZFc.

Dessa forma, após seleção criteriosa, 16 pacientes com azoospermia não obstrutiva idiopática constituíram o grupo amostral e realizaram investigação genômica utilizando a técnica de hibridação genômica comparativa por microarranjo (Figura 11). 
Tabela 1 - Critérios de exclusão para a seleção da amostra.

\begin{tabular}{|c|c|c|}
\hline \multirow{4}{*}{ Pré-testiculares } & \multirow{4}{*}{ Endocrinopatias } & \multirow{2}{*}{$\begin{array}{c}\text { Hipogonadismo hipogonadotrófico } \\
\text { Hiperprolactinemia }\end{array}$} \\
\hline & & \\
\hline & & Hiper/Hipotireoidismo \\
\hline & & Uso de esteroides anabolizantes \\
\hline \multirow{9}{*}{ Testiculares } & \multirow{9}{*}{$\begin{array}{c}\text { Patologias ou } \\
\text { procedimentos que } \\
\text { podem levar à falha na } \\
\text { produção espermática }\end{array}$} & Quimioterapia ou Radioterapia \\
\hline & & Orquite traumática ou infecciosa \\
\hline & & Varicocele ( $\geq$ grau II) \\
\hline & & Criptorquidia bilateral \\
\hline & & Polimorfismos estruturais \\
\hline & & cromossômicos \\
\hline & & Anomalias cromossômicas \\
\hline & & numéricas ou estruturais \\
\hline & & Microdeleções de AZF \\
\hline \multirow{7}{*}{ Pós-testiculares } & & Disfunção erétil/ Perda da \\
\hline & Disfunções Sexuais & libido/Anorgasmia \\
\hline & \multirow{2}{*}{ Disfunção ejaculatória } & Ejaculação \\
\hline & & retrógrada/Anejaculação \\
\hline & Congênitas & CBAVD \\
\hline & \multirow[b]{2}{*}{ Adquiridas } & Vasectomia \\
\hline & & $\begin{array}{l}\text { Obstrução mecânica resultante de } \\
\text { trauma ou infecções }\end{array}$ \\
\hline
\end{tabular}


Figura 11 - Fluxograma da definição do grupo amostral

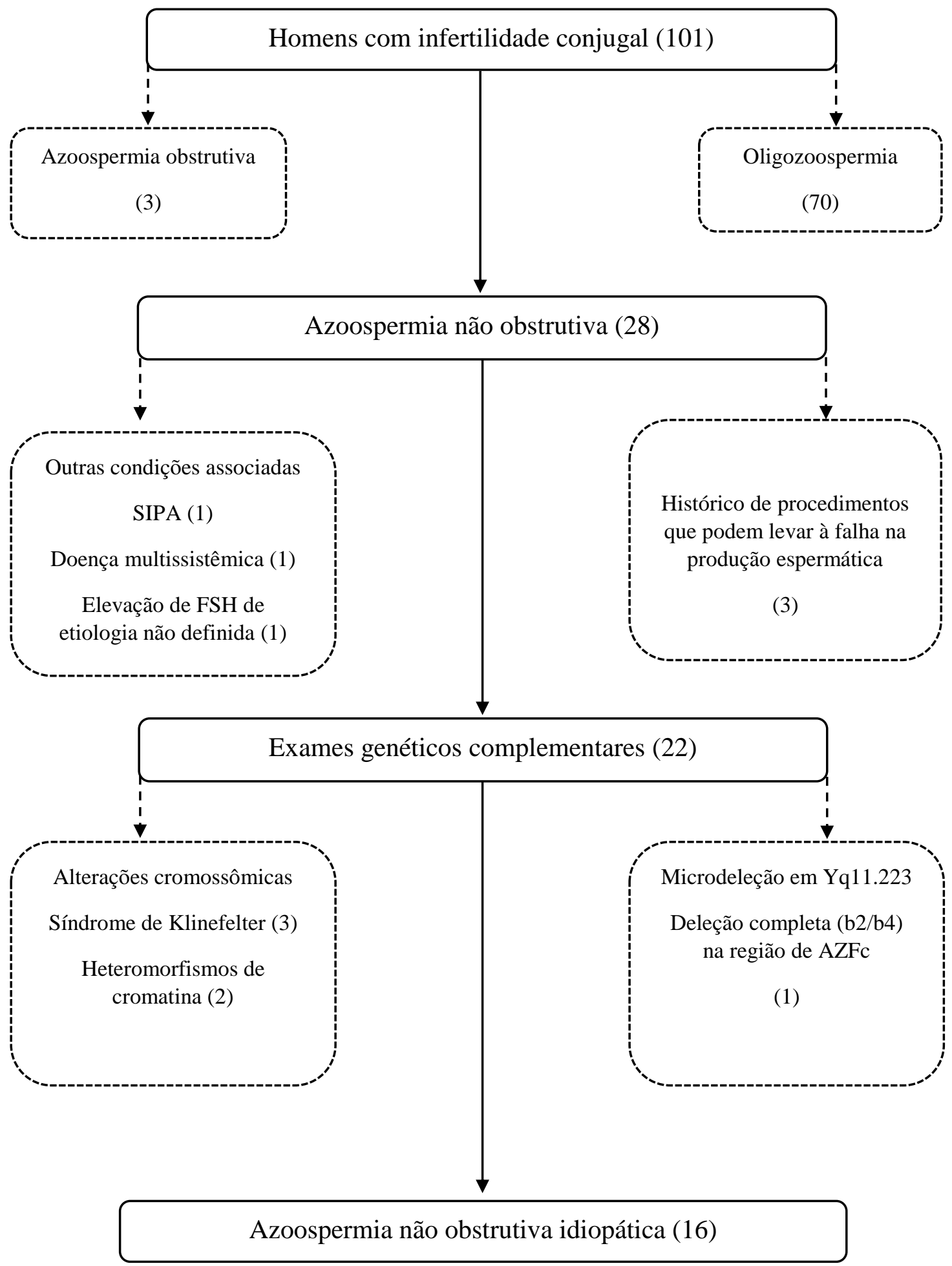




\subsubsection{Grupo Controle}

O grupo controle foi composto por seis homens hígidos com fertilidade clínica determinada pela presença de pelo menos dois filhos e que seguissem os critérios de inclusão e exclusão descritos anteriormente (ANEXO 5).

\subsubsection{Amostras}

Foram coletadas duas amostras de sangue periférico dos pacientes dos grupos amostral e controle para os seguintes fins:

a) Uma amostra com $5 \mathrm{~mL}$ de sangue total, coletado em tubo Vacutainer ${ }^{\circledR}$ contendo $^{\circ}$ heparina sódica, para o estudo citogenético convencional por bandamento GTG para a determinação do cariótipo somático.

b) Uma amostra com de $5 \mathrm{ml}$ de sangue total, coletado em tubo Vacutainer ${ }^{\circledR}$ contendo EDTA, para a realização das técnicas de PCR multiplex (avaliação de microdeleção na região de AZF) e hibridação genômica comparativa por arranjo (avaliação genômica).

Todas as amostras foram armazenadas em geladeira em temperatura média de $4^{\circ} \mathrm{C}$ até o envio ao Laboratório de Citogenética e ao Laboratório de Citogenética Molecular Humana, respectivamente.

\subsection{Métodos}

\subsubsection{Citogenética Clássica}

O estudo citogenético foi realizado no Laboratório de Citogenética do HCFMRP/USP em parceria com o Laboratório de Citogenética Molecular Humana da FMRP/USP utilizando os seguintes protocolos:

\subsubsection{Técnica de Cultura Temporária de Linfócitos}

Uma alíquota de $500 \mu \mathrm{L}$ de sangue foi cultivada em $5 \mathrm{~mL}$ de meio RPMI 1640 (catálogo $\mathrm{n}^{0} 11875, \mathrm{GIBCO}^{\circledR}$, Invitrogen) com L-glutamina, suplementada com $2 \%$ de fitohemaglutinina (catálogo n ${ }^{\circ} 10576-015, \mathrm{GIBCO}^{\circledR}$, Invitrogen), estreptomicina/penicilina (catálogo ${ }^{\circ} 15140-148$, GIBCO $^{\circledR}$, Invitrogen) e 20\% de soro bovino fetal (catálogo ${ }^{\circ} 12657$ $029, \mathrm{GIBCO}^{\circledR}$, Invitrogen), em estufa de $\mathrm{CO}_{2}$, a $37^{\circ} \mathrm{C}$, por 72 horas. Quinze minutos antes 
de completar as 72 horas, foram adicionados $0,3 \mathrm{~mL}$ de colchicina $0,0016 \%$ (catálogo $n^{\circ} \mathrm{C} 3915-1 G$, SIGMA $^{\circledR}$ ) e a solução retornou a estufa.

Ao final do período de incubação, o material foi centrifugado por 10 minutos, a $120 \mathrm{~g}$ e o sobrenadante descartado. Após essa etapa, foram adicionados $5 \mathrm{~mL}$ de solução hipotônica $(\mathrm{KCl} 0,075 \mathrm{M})$, a $37^{\circ} \mathrm{C}$ e o material foi homogeneizado e incubado em banho-maria, por 25 minutos. Foram adicionadas 10 gotas de solução Carnoy (3 metanol: 1 ácido acético) para interromper a ação da solução hipotônica e, após homogeneização, os tubos foram novamente centrifugados por 10 minutos, a $120 \mathrm{~g}$. O sobrenadante foi retirado e o material fixado pela adição de $5 \mathrm{~mL}$ de solução fixadora de Carnoy (3 metanol: 1 ácido acético). $\mathrm{O}$ material foi homogeneizado e mantido por 10 minutos em repouso a $25^{\circ} \mathrm{C}$. Em seguida, centrifugado por 10 minutos, a $120 \mathrm{~g}$ e o sobrenadante descartado. A etapa de fixação foi repetida por mais duas vezes, sendo que da última vez, a concentração da solução fixadora foi de 1 metanol: 1 ácido acético. Parte da suspensão celular resultante foi utilizada para a preparação das lâminas e o restante mantido em freezer a $-20^{\circ} \mathrm{C}$ (MOORHEAD et al., 1960 modificada).

\subsubsection{Técnica de Bandamento GTG}

Para obtenção do bandamento GTG, lâminas contendo a suspensão celular foram mantidas a $25^{\circ} \mathrm{C}$, por três a cinco dias e, logo após, mergulhadas em tripsina (DIFCO 1:250) diluída a $0,1 \%$ em tampão fosfato $(0,06 \mathrm{M}$ pH 6,8), por um período de 1-20 segundos, dependendo do tempo de envelhecimento da lâmina. A ação da tripsina foi neutralizada com água destilada e em seguida, as lâminas foram coradas com solução de Giemsa (MERCK ${ }^{\circledR}$ ) na diluição 1:30, por 10 minutos (SCHERES, 1972).

Foram analisadas 50 metáfases de cada paciente para determinação do cariótipo e exclusão de mosaicismo cromossômico. A análise microscópica foi realizada em microscópio Axio ImagerD2 $\left(\right.$ ZEISS $\left.^{\circledR}\right)$, utilizando objetiva plana APO 100x, acoplado ao sistema computadorizado de análise MetaSystems ${ }^{\circledR}$, utilizando-se o software IKAROS para análise do padrão de bandas, montagem dos cariótipos e documentação dos resultados. 


\subsubsection{Análise Molecular}

As técnicas moleculares foram realizadas no Laboratório de Citogenética Molecular Humana da Faculdade de Medicina de Ribeirão Preto da Universidade de São Paulo (FMRP/USP), ressaltando-se que a técnica de hibridação genômica foi realizada em parceria com o Laboratório de Imunogenética Molecular da mesma instituição.

\subsubsection{A extração de DNA}

\subsection{Lise da amostra de sangue total}

A extração de DNA foi realizada em triplicata com o kit de purificação DNA e RNA MasterPure $^{\circledR}$ (Epicentre Technologies, Madison, EUA), a partir do sangue total coletado. Na primeira etapa, foram adicionados $600 \mu \mathrm{L}$ de solução de lise de células vermelhas do sangue a uma alíquota de $200 \mu \mathrm{L}$ de sangue total em um tubo de 1,5mL. Esse tubo foi invertido, por pelo menos três vezes, para garantir maior homogeneidade da mistura e, logo após, seguiuse a agitação do fundo do tubo para suspensão de qualquer material remanescente. A incubação dessa solução ocorreu em temperatura ambiente por 2 ciclos de 5 minutos, intercalada por uma rápida etapa no agitador vortex. Em seguida, essa solução foi centrifugada em temperatura ambiente, por 25 segundos, para a sedimentação dos glóbulos brancos. O sobrenadante foi quase todo removido, deixando cerca de $25 \mu \mathrm{L}$. Esse sedimento rico em glóbulos brancos foi homogeneizado no agitador vortex e foram adicionados $300 \mu \mathrm{L}$ da solução de lise celular/tecidual e $1 \mu \mathrm{L}$ de RNase A. Essa solução foi mantida a $37^{\circ} \mathrm{C}$, por 30 minutos, e depois mantida em gelo, por 3 a 5 minutos, para extinguir a ação da RNase A.

\subsection{Precipitação do DNA}

Para a precipitação do DNA, $150 \mu \mathrm{L}$ do reagente de precipitação proteica MPC foram adicionados aos $300 \mu \mathrm{L}$ da solução resultante no item anterior e homogeneizados vigorosamente no agitador vortex por 10 segundos. Essa nova solução foi centrifugada a uma temperatura de $4^{\circ} \mathrm{C}$, por 10 minutos e a uma velocidade de $13.000 \mathrm{rpm}$. O sobrenadante foi transferido para um novo tubo de $1,5 \mathrm{~mL}$ e o sedimento descartado. Foram então adicionados $500 \mu \mathrm{L}$ de isopropanol, invertendo-o, por 30-40 vezes, para precipitar o DNA. Em seguida, esse DNA foi sedimentado por centrifugação a $4^{\circ} \mathrm{C}$, por 10 minutos e o isopropanol descartado. O sedimento foi então lavado com etanol 70\%, por duas vezes e por 
fim, diluído em $35 \mu \mathrm{L}$ de tampão TE. As amostras foram então estocadas a $-20^{\circ} \mathrm{C}$ para utilização nas etapas que utilizaram o DNA genômico.

\subsubsection{Análise das microdeleções do cromossomo $Y$}

Para a exclusão de pacientes contendo microdeleções no cromossomo Y foi realizada a análise das regiões AZF utilizando a técnica de PCR multiplex, seguida por eletroforese em gel de agarose.

\subsection{PCR multiplex}

O método foi realizado com o kit Quiagen Multiplex PCR (Catálogo n 206143, Quiagen, Hilden, Alemanha) e os fragmentos iniciadores (primers) da Eurofins Genomics (Ebersberg, Alemanha) desenhados segundo orientação da Academia Europeia de Andrologia (EAA) e da Rede Europeia de Qualidade em Genética Molecular (EMQN).

A técnica é composta pelas reações A e B. Cada reação apresentou volume final de $25 \mu \mathrm{L}$, contendo $9 \mu \mathrm{L}$ de água ultrapura, $2,5 \mu \mathrm{L}$ do mix de primers $\mathrm{A}$ ou $\mathrm{B}, 1 \mu \mathrm{L}$ de DNA em concentração aproximada de 100ng e 12,5 $\mu \mathrm{L}$ do Quiagen Multiplex PCR MasterMix, contendo Hot-StarTaq DNA Polymerase, Quiagen Multiplex PCR Buffer com $6 \mathrm{mM} \mathrm{MgCl} 2$ e mix de dNTP) (Tabela 2).

As condições de amplificação no termociclador iniciaram com uma etapa de ativação $\left(15\right.$ minutos $\left./ 95^{\circ} \mathrm{C}\right)$, seguido pela desnaturação (35 ciclos $/ 30$ segundos $\left./ 94^{\circ} \mathrm{C}\right)$, anelamento $(90$ segundos $/ 60^{\circ} \mathrm{C}$ ) e extensão (90 segundos $\left./ 72^{\circ} \mathrm{C}\right)$. Por fim, realizada uma etapa de extensão por mais 10 minutos, seguida por resfriamento a $4^{\circ} \mathrm{C}$.

\subsection{Eletroforese em gel de agarose}

Os resultados da amplificação foram visualizados por eletroforese em gel de agarose a 2\%, submetido a uma tensão de $90 \mathrm{~V}$, por aproximadamente 2 horas. Em ambas as reações do multiplex foram utilizados um controle feminino, um masculino sem microdeleção e um controle branco, ou seja, sem adição de DNA. Em pacientes sem microdeleção, cinco fragmentos amplificados foram visualizados em ambas as reações. 
Tabela 2 - Lista dos loci e a sequência dos primers utilizados na PCR multiplex para análise das microdeleções de AZF.

\begin{tabular}{|c|c|c|c|c|}
\hline Locus & Primer & Sequência & $\begin{array}{l}\text { Tamanho do } \\
\text { fragmento } \\
\text { amplificado }\end{array}$ & $\begin{array}{l}\text { Status na } \\
\text { deleção } \\
\text { completa }\end{array}$ \\
\hline \multicolumn{5}{|c|}{ Reação A e B } \\
\hline$Z F X / Y$ & $\begin{array}{l}Z F X / Y-\mathrm{F} \\
Z F X / Y-\mathrm{R}\end{array}$ & $\begin{array}{l}\text { 5'-ACC RCT GTA CTG ACT GTG ATT ACA C-3', } \\
\text { 5'-GCA CYT CTT TGG TAT CYG AGA AAG T-3, }\end{array}$ & $495 \mathrm{pb}$ & Presente \\
\hline$S R Y$ & $\begin{array}{l}\text { sY14-F } \\
\text { sY14-R }\end{array}$ & $\begin{array}{l}\text { 5'-GAA TAT TCC CGC TCT CCG GA-3', } \\
\text { 5'-GCT GGT GCT CCA TTC TTG AG-3' }\end{array}$ & $472 \mathrm{pb}$ & Presente \\
\hline \multicolumn{5}{|c|}{ Reação A } \\
\hline $\mathbf{A Z F a}$ & $\begin{array}{l}\text { sY86-F } \\
\text { sY86-R }\end{array}$ & $\begin{array}{l}\text { 5'-GTG ACA CAC AGA CTA TGC TTC-3' } \\
\text { 5'-ACA CAC AGA GGG ACA ACC CT-3' }\end{array}$ & $318 \mathrm{pb}$ & Ausente \\
\hline $\mathbf{A Z F b}$ & $\begin{array}{l}\text { sY127-F } \\
\text { sY127-R }\end{array}$ & $\begin{array}{l}\text { 5'-GGC TCA CAA ACG AAA AGA AA-3', } \\
\text { 5'-CTG CAG GCA GTA ATA AGG GA-3' }\end{array}$ & $274 \mathrm{pb}$ & Ausente \\
\hline AZFc & $\begin{array}{l}\text { sY254-F } \\
\text { sY254-R }\end{array}$ & $\begin{array}{c}\text { 5'-GGG TGT TAC CAG AAG GCA AA-3' } \\
\text { 5'-GAA CCG TAT CTA CCA AAG GAC C-3', }\end{array}$ & $380 \mathrm{pb}$ & Ausente \\
\hline \multicolumn{5}{|c|}{ Reação B } \\
\hline AZFa & $\begin{array}{l}\text { sY84-F } \\
\text { sY84-R }\end{array}$ & $\begin{array}{l}\text { 5'-AGA AGG GTC CTG AAA GCA GGT-3' } \\
\text { 5'-GCC TAC TAC CTG GAG GCT TC-3' }\end{array}$ & $326 \mathrm{pb}$ & Ausente \\
\hline AZFb & $\begin{array}{l}\text { SY134-F } \\
\text { sY134-R }\end{array}$ & $\begin{array}{l}\text { 5'-GTC TGC CTC ACC ATA AAA CG-3', } \\
\text { 5'-ACC ACT GCC AAA ACT TTC AA-3' }\end{array}$ & $301 \mathrm{pb}$ & Ausente \\
\hline AZFc & $\begin{array}{l}\text { SY255-F } \\
\text { sY255-R }\end{array}$ & $\begin{array}{l}\text { 5'- GTT ACA GGA TTC GGC GTG AT-3' } \\
\text { 5'-CTC GTC ATG TGC AGC CAC-3' }\end{array}$ & $123 \mathrm{pb}$ & Ausente \\
\hline
\end{tabular}

Fonte: Adaptado de Krausz et al., 2014.

A primeira banda de ambas as reações correspondeu à amplificação do marcador molecular do gene $Z F X$ (presente tanto no cromossomo $\mathrm{X}$ como no $\mathrm{Y}$ ), servindo como controle interno das reações. A segunda banda correspondeu à amplificação do marcador molecular do gene SRY, presente no cromossomo $\mathrm{Y}$. As bandas subsequentes corresponderam, respectivamente, às amplificações dos STSs correspondentes as regiões de AZFa, AZFb e AZFc (Figura 12).

\subsubsection{Hibridação genômica comparativa em microarranjo}

A técnica de hibridação genômica comparativa foi realizada utilizando a plataforma 4x180K SurePrint G3 CGH+SNP Microarray (Agilent Technologies ${ }^{\circledR}$, Santa Clara, EUA). Esta plataforma apresenta 110.712 sondas para análise das variações no número de cópias (CNVs) e 59.647 sondas para polimorfismos de nucleotídeo único (SNPs), dispostas ao longo de todo o genoma e com um espaçamento médio, entre as sondas, de $25,3 \mathrm{~kb}$. As reações e as análises dessa plataforma seguiram as instruções do fabricante. 
Figura 12 - Imagens dos géis de agarose evidenciando as duas reações (A e B) da PCR multiplex utilizada na detecção das microdeleções de AZF.
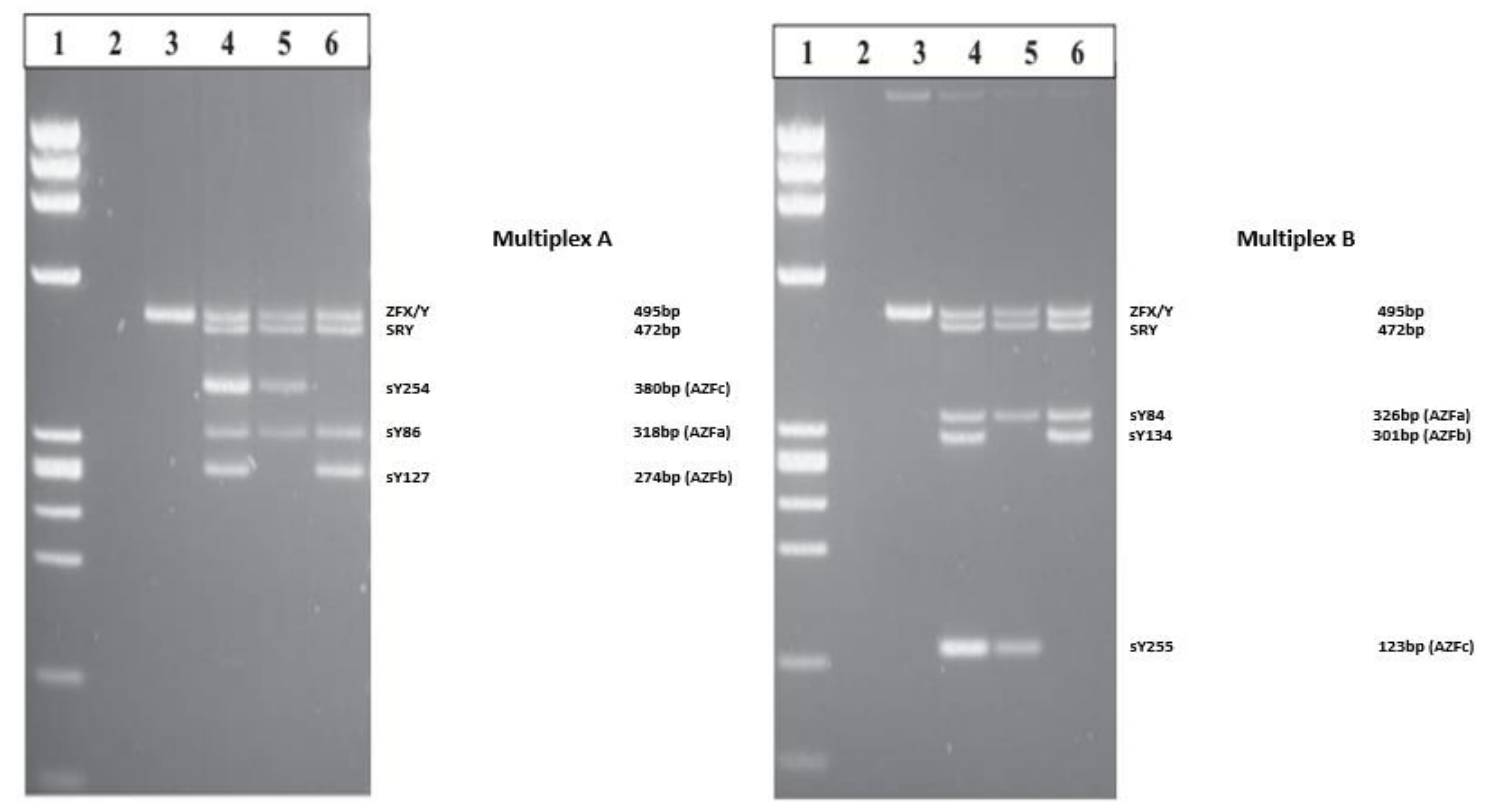

A figura à direita representa gel de agarose com produtos do multiplex A. Na coluna 1 foi aplicado o marcador de peso molecular, na coluna 2 o controle branco, na coluna 3 o controle feminino, na coluna 4 o controle masculino sem microdeleção, na coluna 5 amostra de paciente sem a amplificação do sY127, correspondendo a um dos marcadores de microdeleção de AZFb e na coluna 6 amostra de paciente sem a amplificação do sY254, correspondendo a um dos marcadores de microdeleção de AZFc. A figura à esquerda representa gel de agarose com produtos do multiplex B. Na coluna 1 foi aplicado o marcador de peso molecular, na coluna 2 o controle branco, na coluna 3 o controle feminino, na coluna 4 o controle masculino sem microdeleção, na coluna 5 amostra de paciente sem a amplificação do sY134, correspondendo a um dos marcadores de microdeleção de AZFb e na coluna 6 amostra de paciente sem a amplificação do sY255, correspondendo a um dos marcadores de microdeleção de AZFc. Concluímos então que o paciente 5 apresenta microdeleção completa de $\mathrm{AZFb}$ enquanto que o paciente 6 apresenta microdeleção completa de AZFc (Adaptado de Krausz et al., 2014).

A primeira etapa, após a extração de DNA, foi a verificação da pureza e integridade das amostras através de corrida em gel de agarose. Foram aplicados $10 \mu \mathrm{L}$ da amostra, contendo 250ng de DNA, em gel de agarose a $1 \%$ e então, submetido a uma tensão de $120 \mathrm{~V}$, por 40 minutos. Nesta etapa, foram descartadas as amostras que evidenciaram fragmentação do DNA ou contaminação por RNA.

\subsection{Digestão enzimática e marcação das amostras}

Após a etapa de verificação da pureza e integridade, as amostras foram fragmentadas utilizando uma solução de digestão. Essa solução de digestão foi preparada para um total de oito reações. Metade para o DNA amostral e metade para o DNA controle masculino adquirido da mesma empresa. Essa solução foi preparada com $17 \mu \mathrm{L}$ de água nuclease-free, 
$22,1 \mu \mathrm{L}$ de tampão $10 \mathrm{x}, 1,7 \mu \mathrm{L}$ de BSA acetilado (concentração de $10 \mathrm{mg} / \mu \mathrm{L}$ ) e $4,25 \mu \mathrm{L}$ das

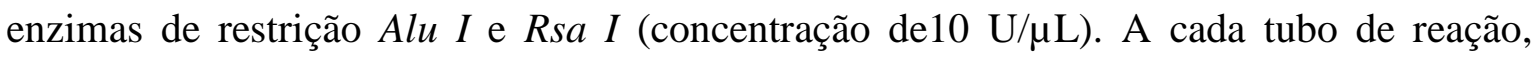
contendo $1 \mu \mathrm{g}$ de DNA genômico diluído em $20,2 \mu \mathrm{L}$ de água ultrapura, foram adicionados $5,8 \mu \mathrm{L}$ da solução de digestão. Esses tubos foram levados ao termociclador, previamente programado para manter as amostras a $37^{\circ} \mathrm{C}$, por duas horas, seguido por um outro ciclo, a $65^{\circ} \mathrm{C}$, por 20 minutos, para inativação das enzimas e mantidas a $4^{\circ} \mathrm{C}$, até a finalização automática da programação. Os tamanhos dos fragmentos gerados, observados em gel de agarose a $1 \%$, variaram de 200 a 800 pb.

O kit Genomic DNA Enzymatic Labeling Kit (Agilent Technologies ${ }^{\circledR}$, Santa Clara, EUA) foi utilizado para a marcação do DNA teste e DNA controle com diferentes fluoróforos. Foram preparadas duas soluções distintas de marcação: uma contendo cianina3 e a outra, cianina-5. Para o preparo dessas soluções de marcação foram utilizados $8,5 \mu \mathrm{L}$ de água nuclease-free, $42,5 \mu \mathrm{L}$ de tampão de reação $5 \mathrm{x}, 21,2 \mu \mathrm{L}$ de dNTPs $10 \mathrm{x}, 4,2 \mu \mathrm{L}$ de ExoKlenow e, em um dos tubos, 6,4 $\mu \mathrm{L}$ do fluoróforo Cyanine 3-Dutp (Cianina-3) e, no outro, $6,4 \mu \mathrm{L}$ do fluoróforo Cyanine 5-Dutp (Cianina-5).

A cada tubo de reação, foram adicionados $21 \mu \mathrm{L}$ da solução de marcação (mix). O mix contendo cianina-3 foi adicionado às reações com DNA controle e o mix contendo Cyanine-5 foi adicionado às reações com DNA amostral. Todos os tubos de reação foram então levados ao termociclador, programado para manter as amostras a $37^{\circ} \mathrm{C}$, por duas horas, em seguida, a $65^{\circ} \mathrm{C}$, por 10 minutos e, por fim, mantidas a $4^{\circ} \mathrm{C}$ até o fim da programação.

\subsection{Purificação da amostra}

A terceira etapa foi a de purificação, realizada com filtros Amicon 30kDa. Primeiramente, foram adicionados $430 \mu \mathrm{L}$ de TE $1 \mathrm{x}(\mathrm{pH}=8.0)$ a cada amostra. Os filtros foram posicionados em tubos de microcentrífuga. As amostras foram então centrifugadas, por 10 minutos, a $14.000 \mathrm{~g}$, em temperatura ambiente. Após o descarte do filtrado, foram adicionados mais $480 \mu \mathrm{L}$ de TE $1 \mathrm{x}$, repetindo a centrifugação e o descarte do filtrado. $\mathrm{O}$ retido, juntamente com o filtro, foi vertido em novo tubo de microcentrífuga de $1,5 \mathrm{~mL}$ e centrifugado, por um minuto, a $1.000 \mathrm{~g}$, em temperatura ambiente, para coletar a amostra purificada. Para equiparar a marcação de todas as amostras, estas foram concentradas ou diluídas em TE 1x. Uma alíquota de 1,5 $\mathrm{L}$, de cada amostra, foi utilizada para determinar o rendimento e atividade específica. Finalmente, a amostra teste e controle, devidamente 
marcadas com cianina-5 e cianina-3, foram combinadas em um único mix, completando um volume total final de $39 \mu \mathrm{L}$.

\subsection{Hibridação}

A etapa seguinte foi a de preparação do DNA marcado para a hibridação. Nesta etapa, foi preparada uma solução de hibridação contendo $21,3 \mu \mathrm{L}$ de Cot-1 DNA (1,0mg/mL), 46,8 $\mu \mathrm{L}$ de 10x aCGH Blocking Agent e 233,8 $\mu \mathrm{L}$ de tampão de hibridação 2x HI-RPM. Um volume de $71 \mu \mathrm{L}$ da solução de hibridação foi adicionado em cada tubo contendo o DNA marcado, totalizando um volume de $110 \mu \mathrm{L}$. Após mistura por pipetagem, as amostras foram levadas ao termociclador programado para dois ciclos: o primeiro, por 3 minutos e a $98^{\circ} \mathrm{C} \mathrm{e}$ o segundo, por 30 minutos e a $37^{\circ} \mathrm{C}$.

Na etapa de hibridação, $100 \mu \mathrm{L}$ do mix de hibridação misturados ao DNA foram depositados nos poços da lamínula, que foi unida a uma lâmina de hibridação e envolvida por uma câmara. Esta câmara foi colocada em um suporte giratório por 24 horas, a uma velocidade de $20 \mathrm{rpm}$ e temperatura de $67^{\circ} \mathrm{C}$ (Figura 13).

\section{Figura 13 - Etapa de hibridação da técnica de Hibridação Genômica Comparativa}
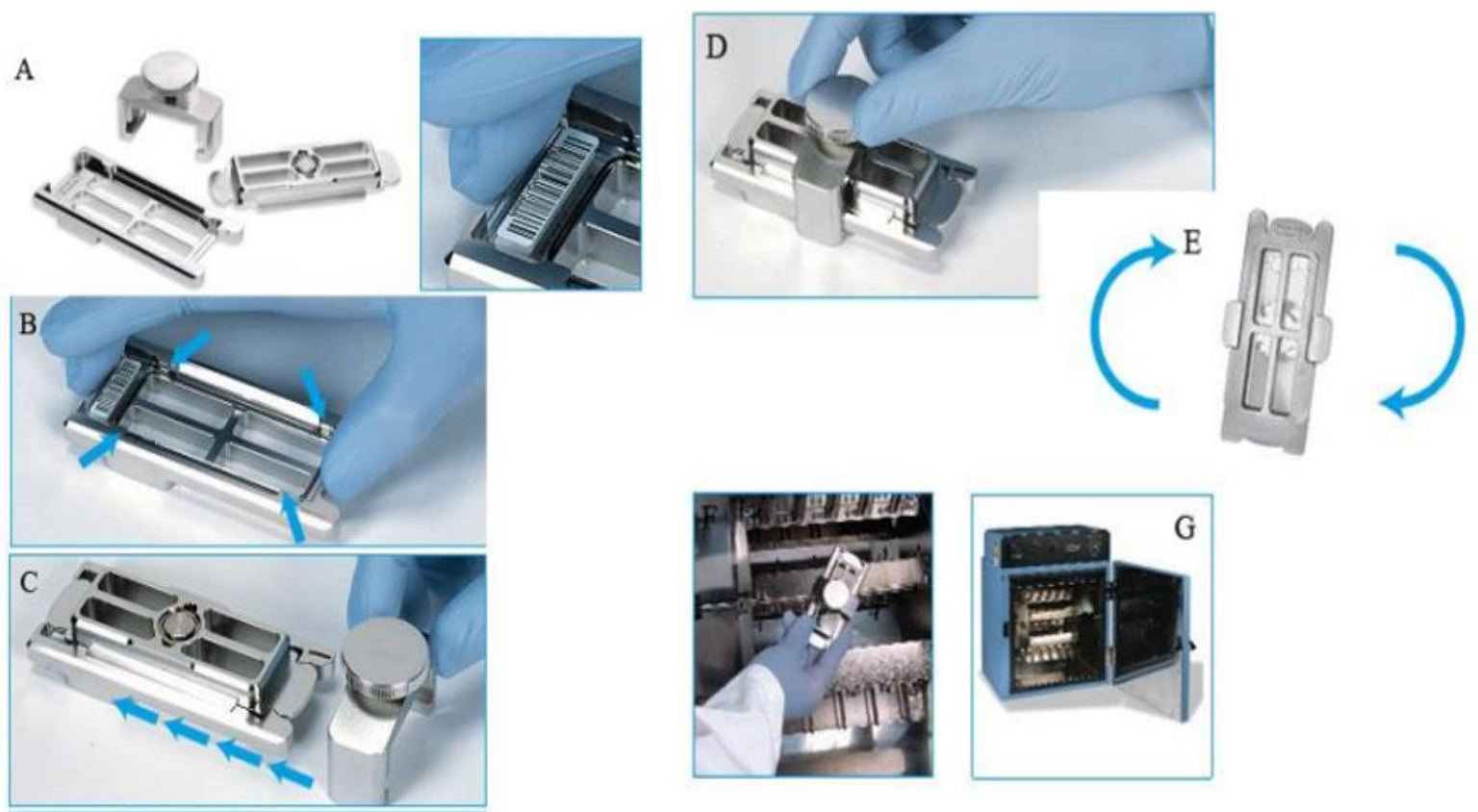

Em A, observamos as peças que são utilizadas para a incubação das lâminas no forno de hibridação. Em B, o encaixe preciso da lâmina e lamínula na base de metal. Em C, a vedação, em D, o selamento com auxílio de uma braçadeira, em E, o conjunto é rodado para observação de bolhas e em F, o acoplamento ao suporte giratório que é levado ao forno em G (Fonte: www.agilent.com). 


\subsection{Lavagem}

A lavagem dos microarranjos foi realizada em ambiente pobre em ozônio. Inicialmente, a lâmina e lamínula foram separadas manualmente enquanto mergulhadas em tampão de lavagem oligoaCGH 1. Esse tampão foi mantido em temperatura ambiente e agitação magnética. A segunda lavagem foi feita com o tampão oligoaCGH 2, a $37^{\circ} \mathrm{C}$, sob agitação magnética, por um minuto. Em seguida, as lâminas foram lavadas em acetonitrila, também em agitação magnética, por 10 segundos. As lâminas foram então mergulhadas em solução de estabilização e secagem, sob agitação, por 30 segundos.

\subsection{Escaneamento e extração dos dados}

Após a etapa de lavagem, as lâminas foram imediatamente posicionadas no suporte SureScan para escaneamento. Para essa etapa foram utilizados um scanner (Agilent SureScan B Scanner) e um programa para a análise das imagens (The Feature Extraction software v12.0). Os parâmetros para extração dos dados seguiram as instruções determinadas pelo fabricante. Os dados foram extraídos em formato .TXT e foram normalizados pelo software Nexus Copy Number v8.0 (Biodiscovery, Santa Clara), utilizando o Fast Adaptive States Segmentation Technique (FASST2) com um limiar de significância de 5.0 e um espaço máximo entre sondas adjacentes de $10.000 \mathrm{~kb}$.

\subsubsection{Análise Bioinformática}

Alterações no número de cópias menores que $1 \mathrm{~Kb}$ e/ou incluindo menos de 3 sondas adjacentes foram desconsideradas, assim como as perdas de heterozigosidade (LOH) menores que $1 \mathrm{Mb}$. Foi considerado ganho um limiar de 0,5 ; alto ganho um limiar de 1,1; perdas, -0,5; e perdas em homozigose, 1,1. As regiões alteradas foram descritas utilizando o GRCh37/hg19 como sequencia referência.

As regiões que apresentaram perdas e ganhos significativos foram visualmente avaliadas pela interface do software Nexus Copy Number v8.0. Comparamos o perfil genômico, entre casos e controles, utilizando a ferramenta comparação do software, que mostra regiões significativamente alteradas a partir do teste exato de Fisher, com limiar de alteração de $25 \%$ e $\mathrm{p}<0.05$.

Para análise comparativa das CNVs do tipo ganho e perda, cada variante foi individualmente analisada seguindo as seguintes etapas: 
a) Comparação dessas variantes entre grupo amostral e controle;

b) Análise no DGV para exclusão de variantes comuns;

c) Comparação das variantes detectadas com aquelas descritas em um banco de dados específico em infertilidade masculina. Esse banco de dados foi construído a partir da busca de artigos na literatura e contou seis diferentes trabalhos científicos que utilizaram a hibridação genômica na avaliação da falência espermatogênica primária (ANEXO 6).

\subsubsection{Análise Estatística}

As variáveis clínicas como idade e dosagem de gonadotrofinas foram comparadas entre o grupo controle e o de pacientes com azoospermia não obstrutiva pelo teste MannWhitney. As comparações entre as variáveis número total de perdas e ganhos e número total de LOHs, entre os dois grupos, utilizaram o teste Kruskal-Wallis. Todas as análises estatísticas foram realizadas através do software R v3.4.2. Diferenças significativas foram observadas quando $\mathrm{P}<0.05$. 


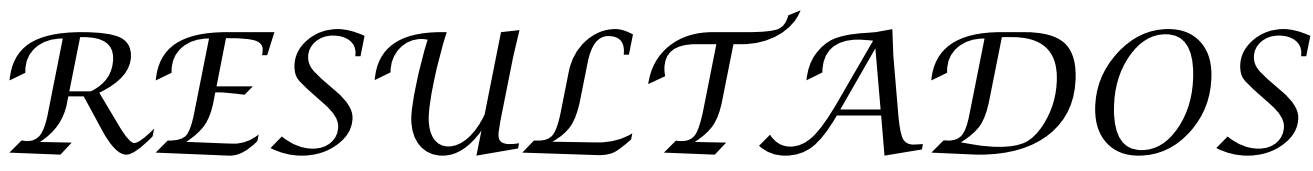

"Temos fé em Deus [...] todos os outros precisam ter dados"

Bernard Fisher 


\section{RESULTADOS}

\subsection{Análise descritiva dos parâmetros clínicos}

A partir da comparação de dados clínicos de pacientes e controles, observamos que os indivíduos inférteis apresentam idades inferiores e níveis de testosterona reduzidos quando comparados ao grupo controle ( $\mathrm{P}=0.006$ e $\mathrm{P}=0.019$, respectivamente), enquanto que os valores das gonadotrofinas (FSH e LH) não apresentaram diferença estatisticamente significante quando comparados entre os dois grupos ( $\mathrm{P}=0.42$ e $\mathrm{P}=0.15$, respectivamente) (Tabela 3).

Tabela 3 - Comparação dos parâmetros clínicos entre os grupos de estudo

\begin{tabular}{lccc}
\hline & Caso & Controle & $\mathrm{P}$ \\
\cline { 2 - 4 } Idade (anos) (média; mediana) & $33 ; 33$ & $38 ; 38$ & 0.006 \\
Testosterona (unidade) (média; mediana) & $392 ; 383$ & $500 ; 520$ & 0.019 \\
FSH (unidade) (média; mediana) & $12.9 ; 8.3$ & $4.8 ; 4.8$ & 0.42 \\
LH (unidade) (média; mediana) & $4.4 ; 4.2$ & $3.0 ; 3.1$ & 0.15 \\
\hline
\end{tabular}

(O valor de $P$ foi obtido através do teste Mann-Whitney)

\subsection{Distribuição das variações genômicas}

A análise inicial dos dados de hibridação genômica comparativa evidenciou que todos os pacientes, sejam do grupo controle ou amostral, apresentaram algum tipo de alteração genômica (CNV ou LOH) (Figura 14). Um total de 68 dessas variantes foram observadas no grupo controle e 184 no grupo amostral. A média entre o número de variações genômicas e o número de pacientes em ambos os grupos foi, respectivamente, de 11,3 e 11,5 (Tabela 4).

Não foram observadas diferenças estatisticamente significativas entre o número total de alterações genômicas entre pacientes inférteis e controles tanto quando comparadas de forma isolada como agrupada (Figura 15). O mesmo também foi observado quando os diferentes tipos de variantes de número de cópias ( $\mathrm{CNVs}$ ) foram analisados separadamente (Figura 16). 
Figura 14 - Distribuição das alterações genômicas no grupo controle e no grupo azoospermia não obstrutiva

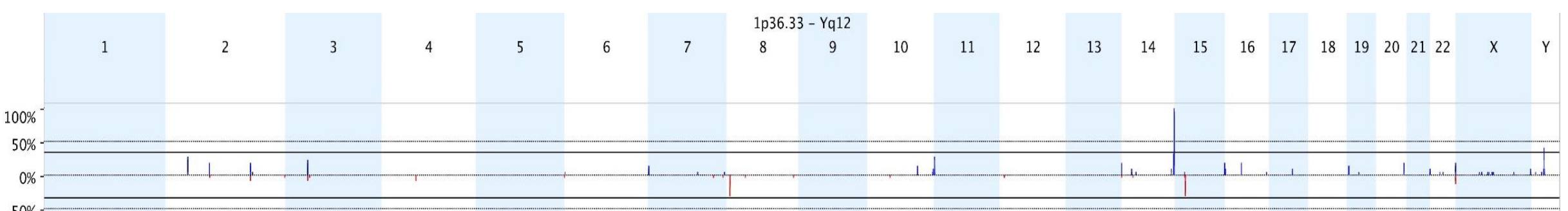

$50 \%-$

$100 \%$

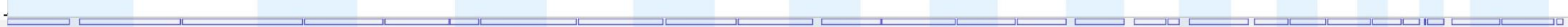

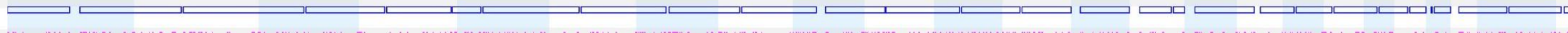

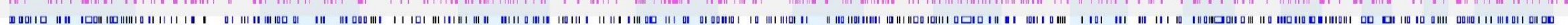

$\mathrm{C} 1-\mathrm{C} 6$

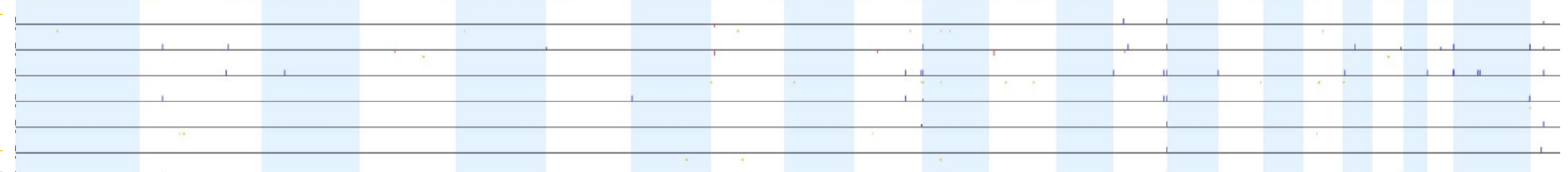

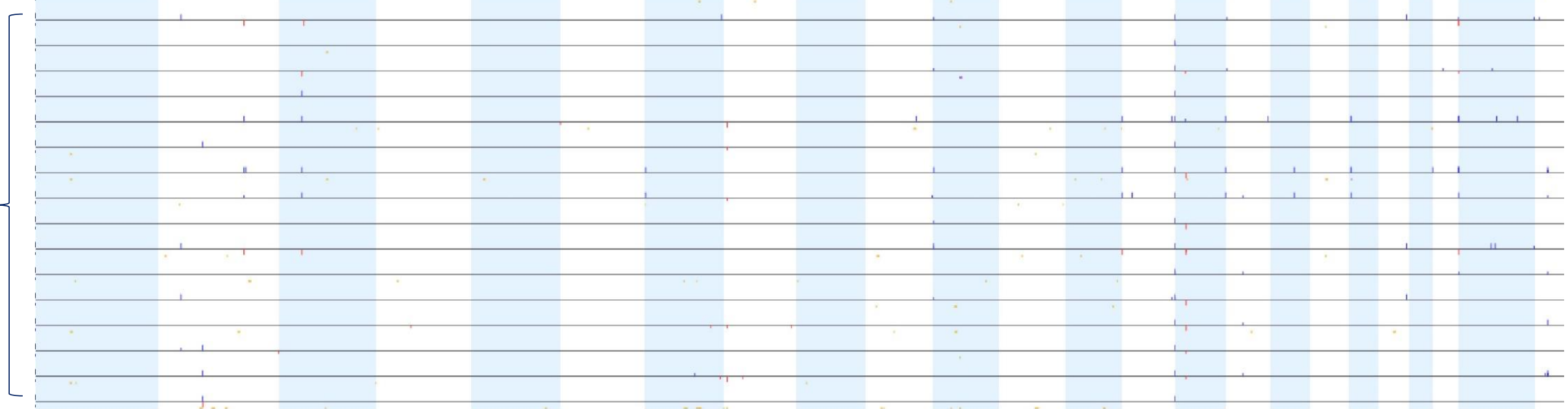

Cada linha horizontal representa as alterações genômicas observadas pela técnica de hibridação genômica comparativa nos indivíduos do grupo controle (C1-C6) e do grupo amostral (A-P). As linhas verticais de cor azul, acima da linha horizontal, representam os ganhos, enquanto que as linhas verticais vermelhas correspondem às perdas. Linhas horizontais amarelas, localizadas abaixo da linha principal, correspondem às regiões de perda de heterozigose. As colunas verticais, de coloração alternada azul e branco, correspondem à localização dessas alterações nos cromossomos. 
Tabela 4 - Avaliação quantitativa das alterações genômicas detectadas no grupo controle (C1-C6) e no grupo de pacientes com azoospermia não obstrutiva idiopática (A-P)

\begin{tabular}{|c|c|c|c|c|}
\hline \multirow[b]{2}{*}{ Amostras } & \multicolumn{2}{|c|}{ CNVs } & \multirow{2}{*}{$\mathbf{L O H}$} & \multirow{2}{*}{ Total } \\
\hline & Ganhos & Perdas & & \\
\hline C1 & 3 & 1 & 7 & 11 \\
\hline $\mathrm{C2}$ & 8 & 5 & 2 & 16 \\
\hline C3 & 13 & 0 & 10 & 26 \\
\hline $\mathrm{C4}$ & 6 & 0 & 1 & 7 \\
\hline C5 & 3 & 0 & 4 & 7 \\
\hline C6 & 2 & 0 & 3 & 5 \\
\hline $\begin{array}{c}\text { Grupo } \\
\text { Controle }\end{array}$ & 35 & 6 & 27 & 68 \\
\hline A & 9 & 4 & 2 & 16 \\
\hline B & 1 & 0 & 1 & 3 \\
\hline $\mathbf{C}$ & 5 & 2 & 1 & 8 \\
\hline D & 2 & 0 & 0 & 2 \\
\hline $\mathbf{E}$ & 11 & 2 & 9 & 26 \\
\hline $\mathbf{F}$ & 2 & 1 & 2 & 5 \\
\hline $\mathbf{G}$ & 13 & 1 & 7 & 28 \\
\hline $\mathbf{H}$ & 12 & 1 & 4 & 17 \\
\hline I & 2 & 1 & 0 & 3 \\
\hline $\mathbf{J}$ & 7 & 4 & 6 & 18 \\
\hline $\mathbf{K}$ & 4 & 0 & 8 & 13 \\
\hline $\mathbf{L}$ & 6 & 1 & 2 & 10 \\
\hline M & 3 & 5 & 6 & 14 \\
\hline $\mathbf{N}$ & 3 & 2 & 1 & 6 \\
\hline $\mathbf{O}$ & 6 & 4 & 3 & 17 \\
\hline $\mathbf{P}$ & 2 & 1 & 15 & 18 \\
\hline $\begin{array}{c}\text { Grupo } \\
\text { amostral }\end{array}$ & 88 & 29 & 67 & 184 \\
\hline
\end{tabular}


Figura 15 - Distribuição do número de alterações genômicas em ambos os grupos

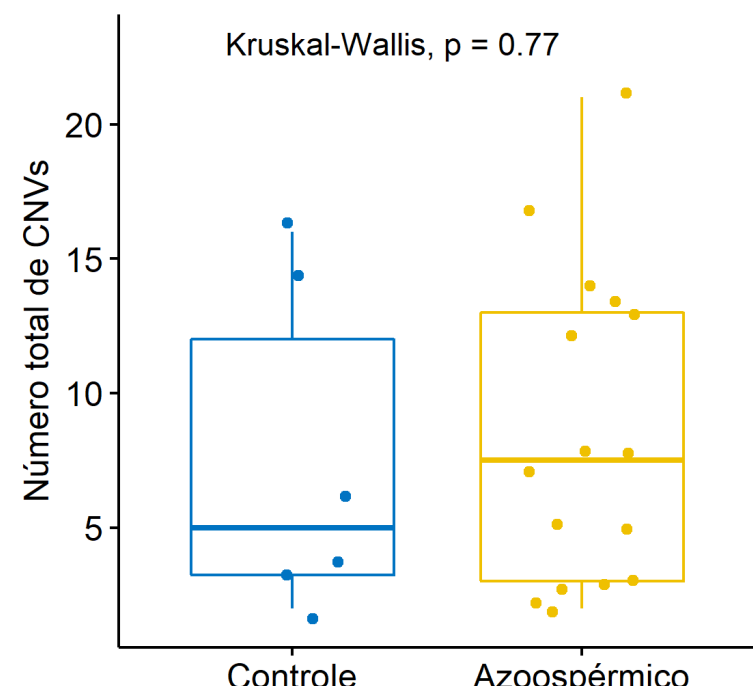

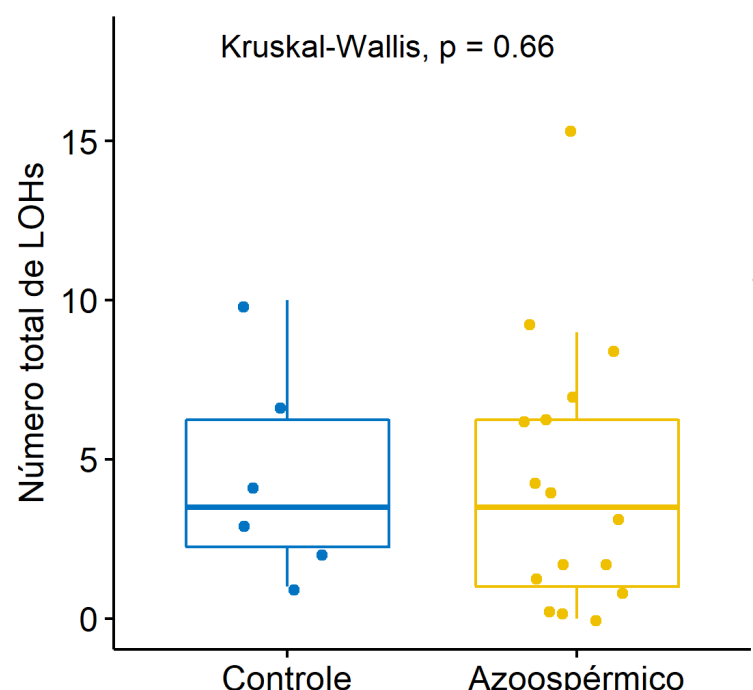

B

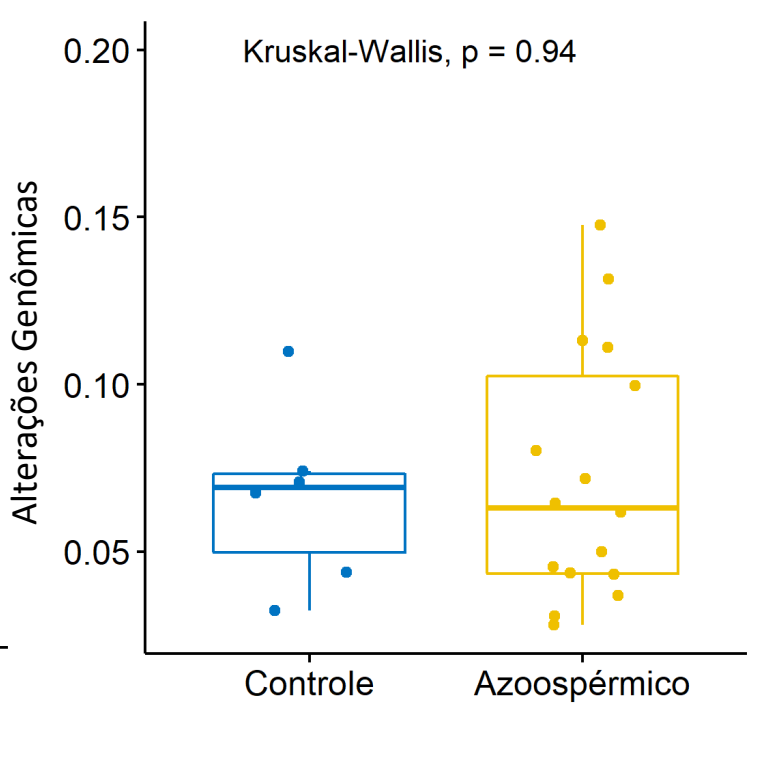

C

$\mathrm{Na}$ figura $\mathrm{A}$, não foi observada diferença significativa $(\mathrm{P}=0,77)$ na distribuição do número total de variantes de número de cópias em ambos os grupos. $\mathrm{O}$ mesmo pode ser observado na figura $\mathrm{B}$, quando foram analisadas o número total de regiões de perda de heterozigose $(\mathrm{P}=0,66)$. Em $\mathrm{C}$, também não foi significativa $(\mathrm{P}=0,94)$ a razão entre o número de variantes genômicas e a média de indivíduos em cada grupo. 
Figura 16 - Distribuição dos diferentes tipos de variantes de número de cópias (CNVs) e a média de indivíduos em cada grupo

A

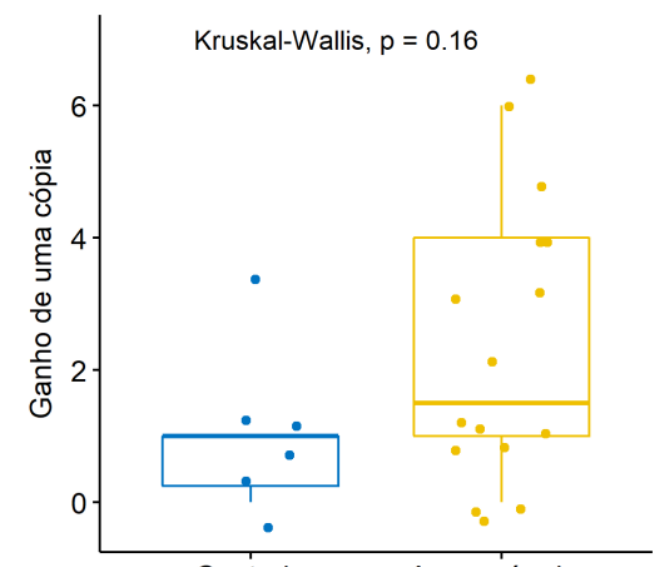

Controle

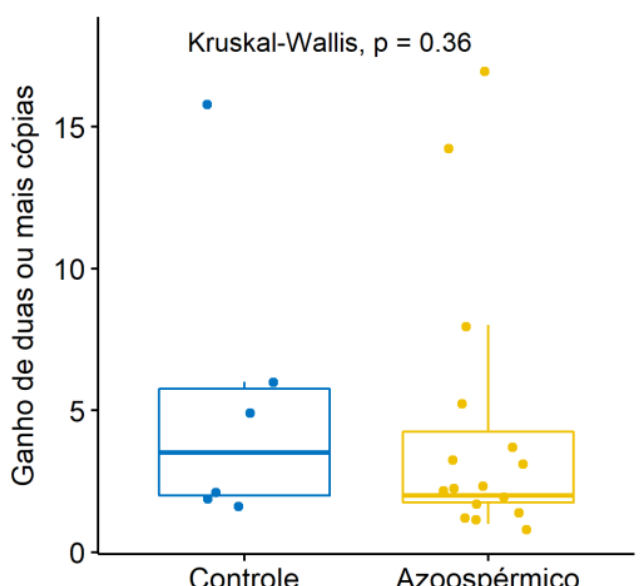

Controle

Azoospérmico
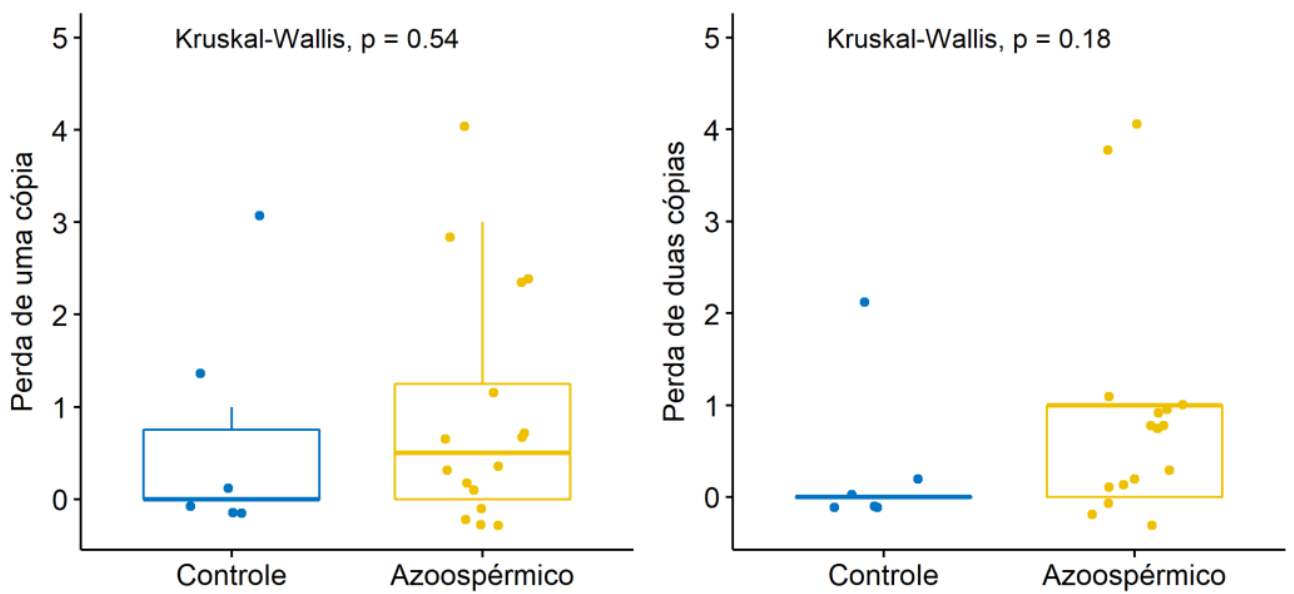

Na figura A, observamos que não houve diferença estatisticamente significativa entre a razão dos diferentes tipos de ganho e a média dos indivíduos, em cada grupo analisado. O mesmo pode ser observado na figura B, quando os diferentes tipos de perda foram analisados. 


\subsubsection{Distribuição e comparação entre grupos das Variantes de Número de Cópias (CNVs)}

Foram descritas $41 \mathrm{CNVs}$ no grupo controle, sendo 35 delas do tipo ganho e 6 do tipo perda. No grupo amostral foram evidenciadas 117 CNVs, sendo 88 do tipo ganho e 29 perdas. Não houve diferença entre o número dessas alterações e o número médio de indivíduos em ambos os grupos analisados. No grupo controle essa média foi de 6,8, enquanto no grupo infértil foi de 7,3 (Tabela 4).

Também não foram observadas diferenças significativas quanto à distribuição dos 3 grupos de tamanho de CNVs (1-99kb, 100-499 e >500kb), pela média de indivíduos, nos grupos analisados. Essa mesma característica foi notada na análise isolada dos ganhos, porém, nas variações do tipo perda, observamos que aquelas com tamanho compreendido entre 100-499kb foram mais comuns no grupo amostral. Não foram descritas CNVs menores que $100 \mathrm{~kb}$ no grupo controle (Figura 17).

A distribuição das CNVs nos diferentes cromossomos, em relação à média dos indivíduos nos diferentes grupos, não foi homogênea. Os cromossomos 1, 5, 9 e 18 não apresentaram nenhuma dessas variantes, diferentemente dos cromossomos 2, 14, X e Y que evidenciaram maior número dessas alterações. Além disso, CNVs restritas ao grupo amostral foram identificadas nos cromossomos 6, 15 e 17, enquanto que as restritas ao grupo controle foram observadas exclusivamente no cromossomo 12 (Figura 18). Quando essas variantes foram analisadas de forma isolada, percebemos que os ganhos apresentaram distribuição mais homogênea do que as perdas. As deleções restritas ao grupo amostral foram identificadas nos cromossomos 2, 3, 6, 7, 13, 22 e X, enquanto que deleções restritas ao grupo controle foram observadas nos cromossomos 10, 12 e 14. Não foram observadas deleções no cromossomo Y em ambos os grupos (Figura 18). 
Figura 17 - Distribuição do tamanho das variantes de número de cópias (CNVs) pela média de indivíduos no grupo amostral e controle

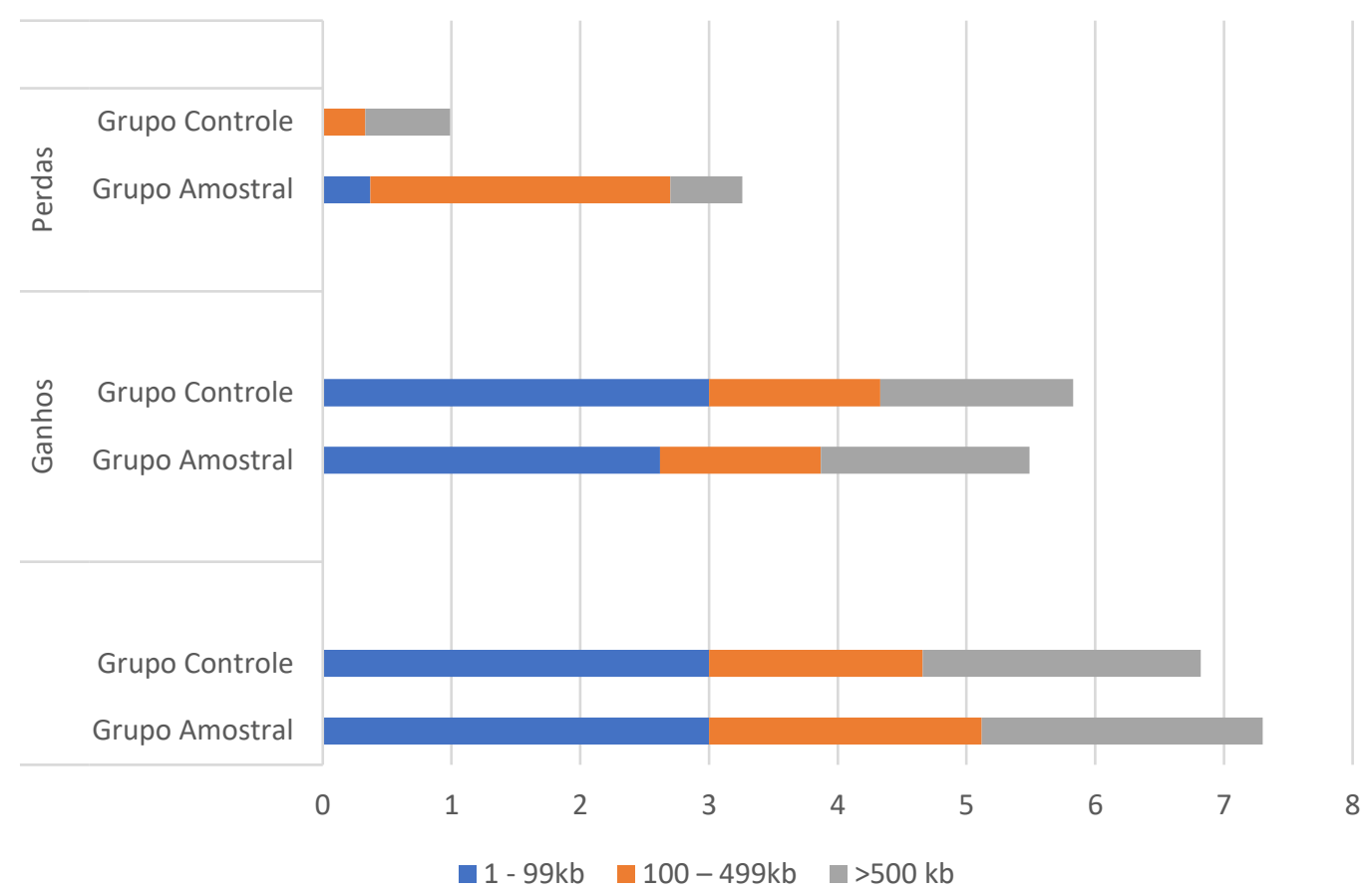

Figura 18 - Distribuição das variantes de número de cópias (CNVs) pela média de indivíduos nos grupos amostral e controle nos diferentes cromossomos

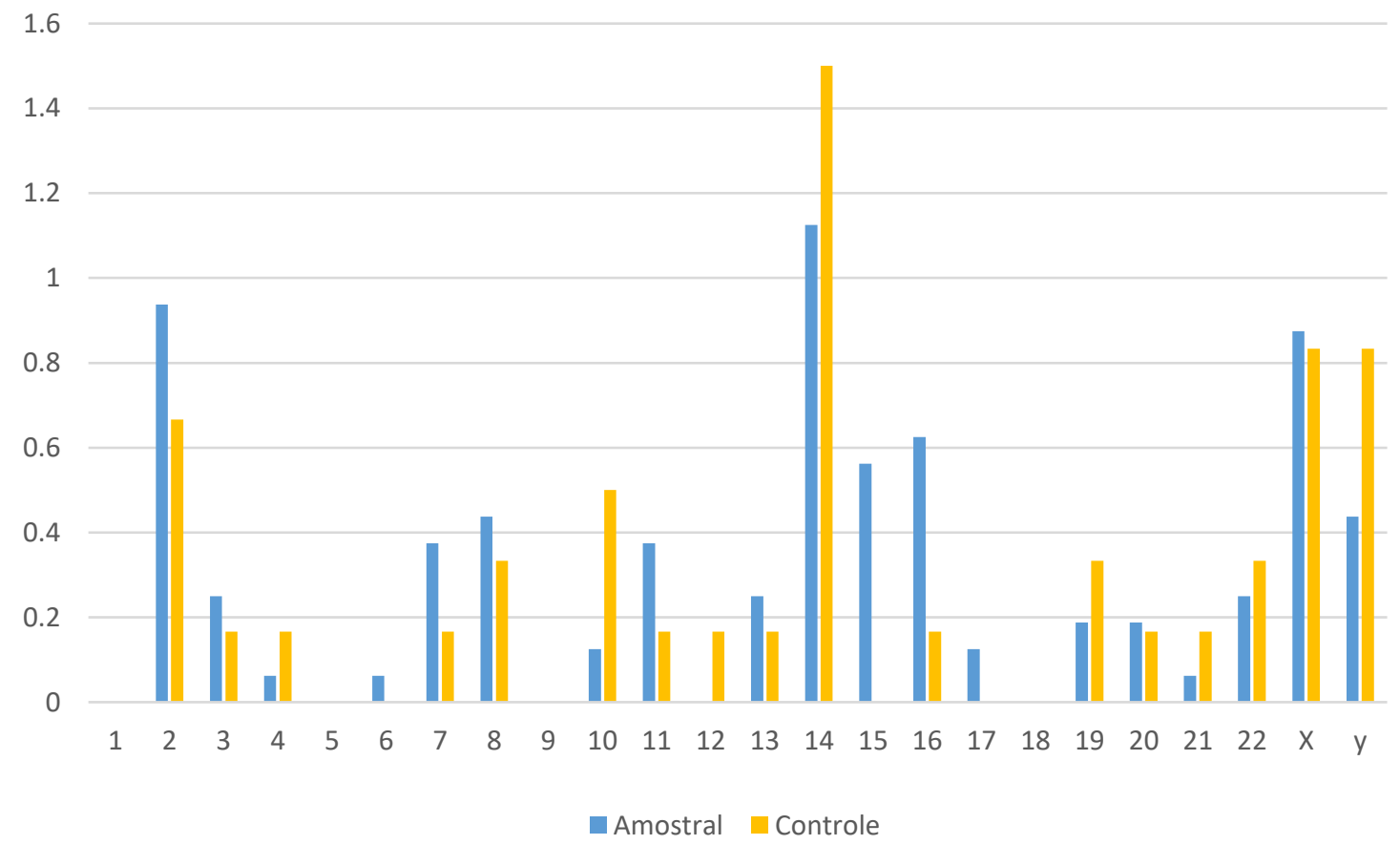


Figura 19 - Distribuição das variantes de número de cópias (CNVs) do tipo ganho e perda, pela média de indivíduos em ambos os grupos, nos diferentes cromossomos
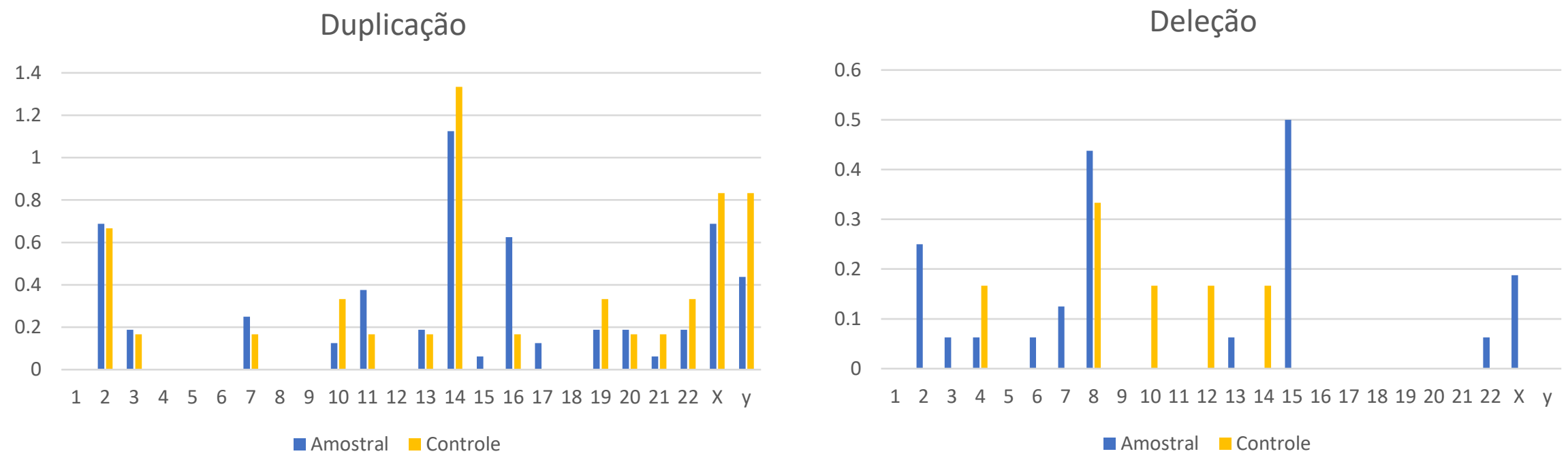


\subsubsection{Distribuição e comparação entre grupos das Variantes de Número de Cópias do tipo ganho}

O total de ganhos observados na população em estudo foi de 123, sendo 35 na população controle e 88 na população amostral. Não houve diferença significativa entre a relação do número de ganhos e a média de indivíduos em cada grupo. A média observada no grupo controle e amostral foi, respectivamente, de 5,8 e 5,5.

A distribuição das CNVs do tipo ganho nos diferentes cromossomos revelou que em oito cromossomos $(1,4,5,6,8,9,12$ e 18) nenhuma dessas alterações foi detectada. Os cromossomos 15 e 17 evidenciaram ganhos apenas no grupo amostral e os ganhos observados nos cromossomos sexuais foram mais comuns no grupo controle (Figura 19).

A análise comparativa entre os ganhos observados nos dois grupos evidenciou que do total de 123 ganhos, 21 foram compartilhados por indivíduos do grupo controle e amostral e considerados como não relevantes, assim como os 5 ganhos restritos aos indivíduos do grupo controle. Dentre as alterações restritas ao grupo de pacientes com azoospermia não obstrutiva, 7 foram compartilhadas por mais de um indivíduo e 12 classificadas como individuais. Após análise individual de cada ganho pelo DGV, 8 foram excluídas por se tratarem de CNVs comuns, descritas em pacientes assintomáticos. Dessa forma, apenas 11 ganhos, 7 individuais e 4 compartilhados, foram classificados como raros e significativos (Figura 20).

A tabela 5 descreve a localização, posição genômica, tamanho e conteúdo gênico dos 7 ganhos classificados como restritos, individuais e raros. Dois desses ganhos foram detectados em autossomos (7 e 16) e cinco nos cromossomos sexuais, sendo quatro no braço longo do cromossomo $\mathrm{X}$ e um no braço curto do cromossomo $\mathrm{Y}$. O tamanho desses ganhos variou de $1,2 \mathrm{~kb}$ até $894 \mathrm{~kb}$ e todos continham genes codificantes de proteína, com exceção da CNV localizada no braço curto do cromossomo Y.

A tabela 6 descreve a localização, posição genômica, tamanho, conteúdo gênico e indivíduos do grupo amostral que compartilharam 4 diferentes ganhos. Esses ganhos predominaram nos autossomos, em detrimento dos cromossomos sexuais. O tamanho desses ganhos variou de $16-139 \mathrm{~kb}$ e todos continham genes codificantes de proteínas. Foi descrito um único ganho raro e compartilhado na sub-banda q28 do cromossomo X. 
Figura 20 - Fluxograma da distribuição das CNVs do tipo ganho

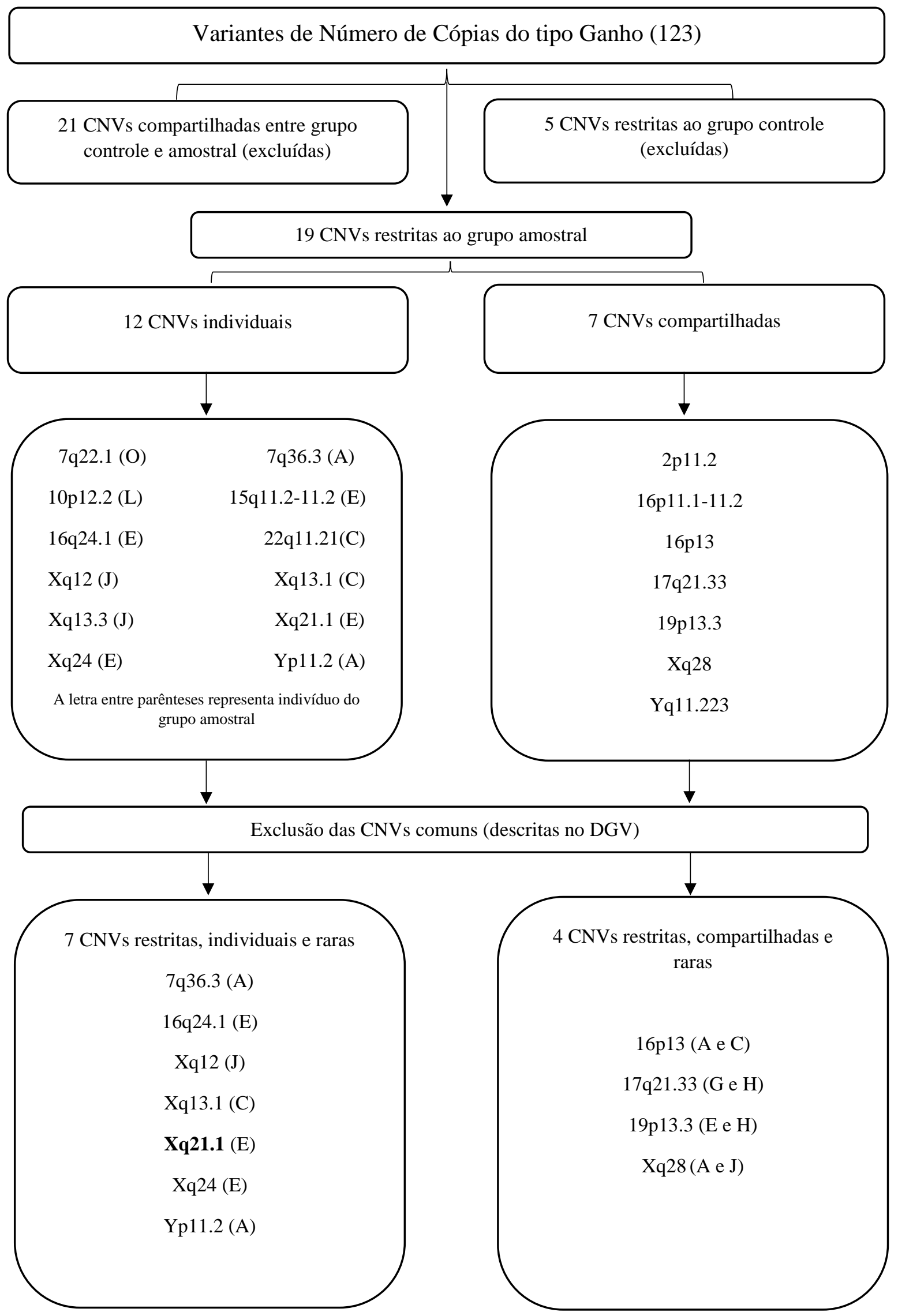


Tabela 5 - CNVs do tipo ganho, restritas ao grupo amostral, individuais e raras

\begin{tabular}{|c|c|c|c|c|}
\hline Cromossomo & Banda & Posição Genômica & Tamanho & Genes \\
\hline 7 & q36.3 & $\begin{array}{l}155,596,329- \\
155,600,169\end{array}$ & $3,8 \mathrm{~kb}$ & $\mathrm{SHH}$ \\
\hline 16 & $\mathrm{q} 24.1$ & $85,549,343-85,667,640$ & $118 \mathrm{~kb}$ & GSE1 \\
\hline $\mathbf{X}$ & $\mathrm{q} 12$ & $65,760,836-65,939,751$ & $178 \mathrm{~kb}$ & $U P R T$ e $Z D H H C 15$ \\
\hline $\mathbf{X}$ & q13.1 & $67,950,466-68,845,123$ & $894 \mathrm{~kb}$ & $\begin{array}{c}\text { EFNB1, PJA1, } \\
\text { LINC00269, } \\
\text { FAM155B, EDA }\end{array}$ \\
\hline $\mathbf{X}$ & $\mathrm{q} 21.1$ & $77,158,835-77,160,060$ & $1,2 \mathrm{~kb}$ & $C O X 7 B$ \\
\hline $\mathbf{X}$ & $\mathrm{q} 24$ & $\begin{array}{l}118,986,572- \\
119,007,025\end{array}$ & $20 \mathrm{~kb}$ & $\begin{array}{c}\text { UPF3B, RNF113A, } \\
\text { NDUFA1 }\end{array}$ \\
\hline $\mathbf{Y}$ & $\mathrm{p} 11.2$ & $8,406,069-8,512,073$ & $106 \mathrm{~kb}$ & LINC00279 \\
\hline
\end{tabular}


Tabela 6 - CNVs do tipo ganho, restritas ao grupo amostral, compartilhadas e raras

\begin{tabular}{|c|c|c|c|c|c|}
\hline Cromossomo & Banda & Posição Genômica & Tamanho & Genes & Indivíduos \\
\hline 16 & $\mathrm{p} 13$ & $2,127,944-2,144,285$ & $16 \mathrm{~kb}$ & $\begin{array}{c}\text { TSC2, MIR1225, } \\
\text { LOC } 105371049, \\
\text { PKD1 }\end{array}$ & $(\mathrm{A}$ e $\mathrm{C})$ \\
\hline 17 & $\mathrm{q} 21.33$ & $48,241,425-48,273,531$ & $32 \mathrm{~kb}$ & $\begin{array}{c}\text { SGCA, HILS1, } \\
\text { COL1A1 }\end{array}$ & $(\mathrm{G}$ e $\mathrm{H})$ \\
\hline 19 & $\mathrm{p} 13.3$ & $85,549,343-85,667,640$ & $139 \mathrm{~kb}$ & $\begin{array}{c}\text { PLIN4, PLIN5, } \\
\text { LRG1, SEMA6B, } \\
\text { TNFAIP8L1 }\end{array}$ & $(\mathrm{E}$ e H$)$ \\
\hline $\mathbf{X}$ & q28 & $153,169,981-153,205,446$ & $35 \mathrm{~kb}$ & $\begin{array}{c}A V P R 2, A R H G A P 4, \\
N A A 10, R E N B P\end{array}$ & $(\mathrm{~A}$ e $\mathrm{J})$ \\
\hline
\end{tabular}


Figura 21 - CNV do tipo ganho, restrita ao grupo amostral, individual e rara, localizada em 7q36.3

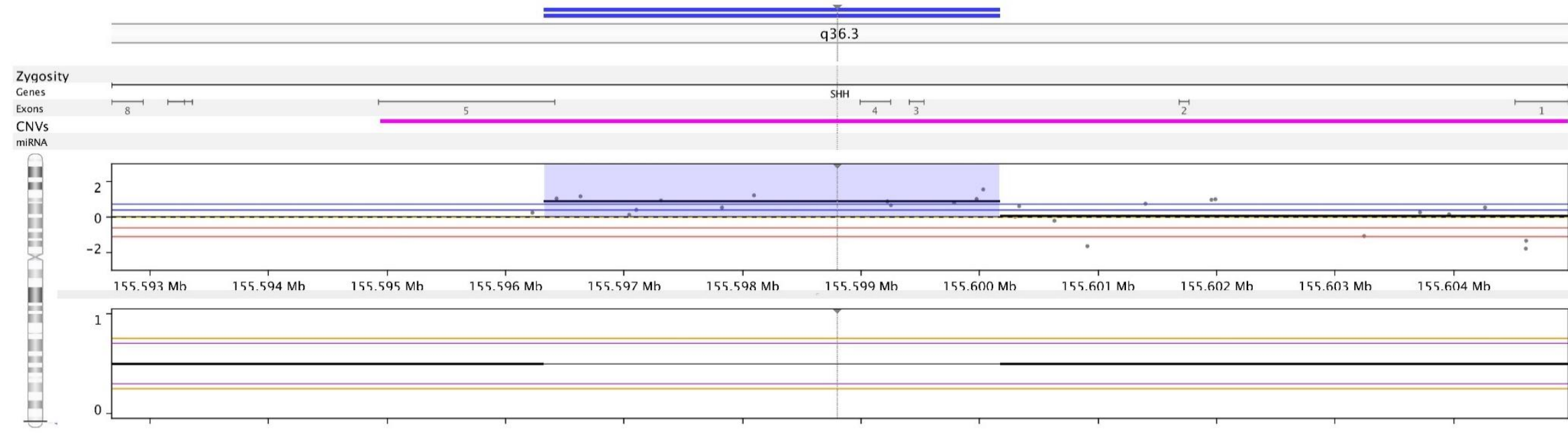

Na figura observamos a localização e a extensão (barras azuis) do ganho detectado no indivíduo A e o envolvimento do gene $S H H$. 
Figura 22 - CNV do tipo ganho, restrita ao grupo amostral, individual, rara e sem descrição no DGV, localizada em Xq21.1

A

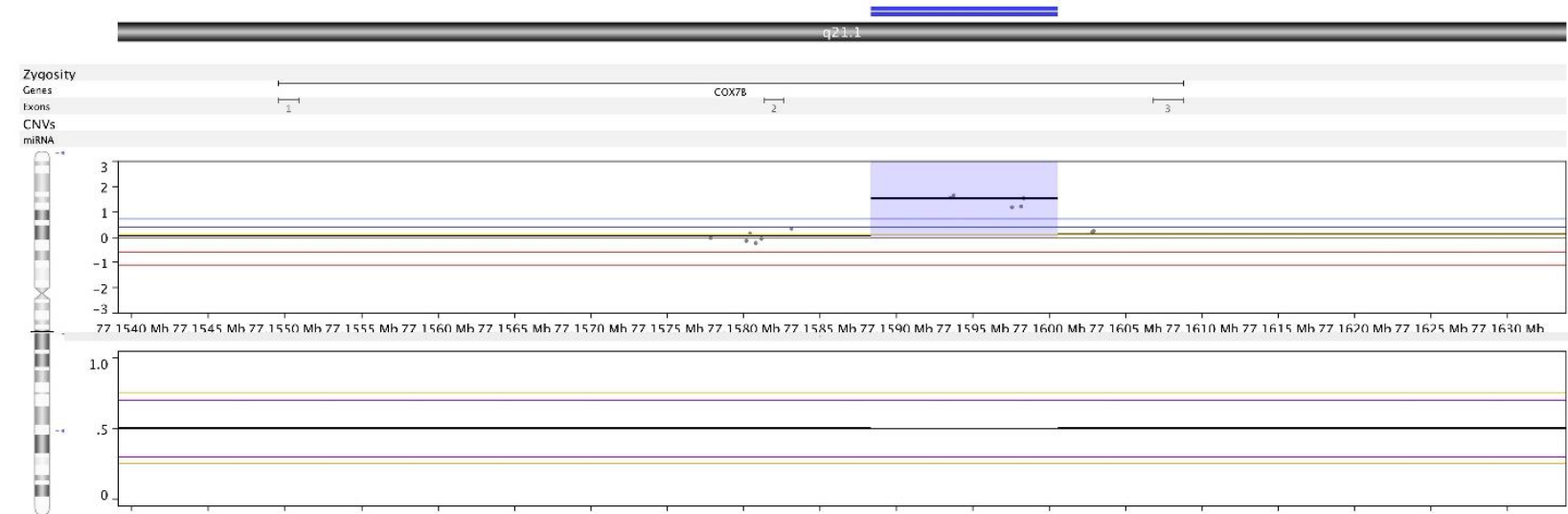

$\operatorname{chr} \times$

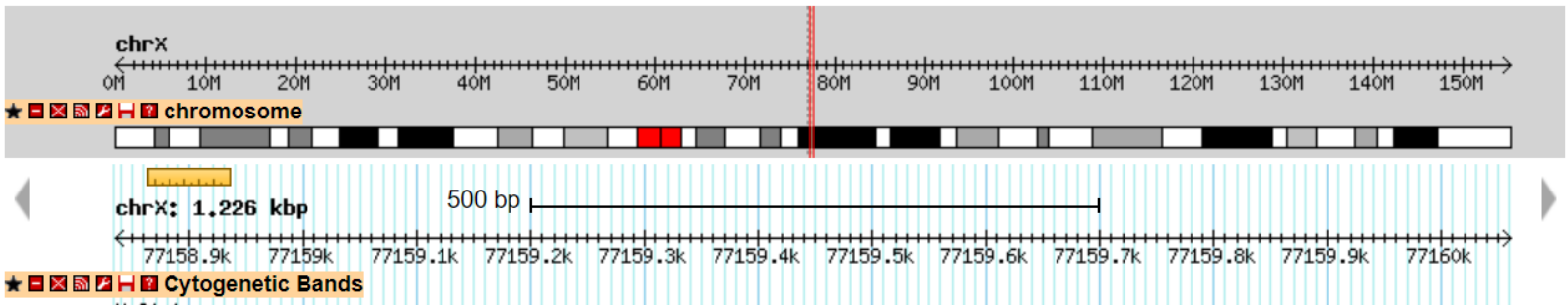
太曰国国H Cytogenetic Bands

ॠ日ब $\star \Delta \otimes$ 国 *

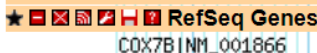

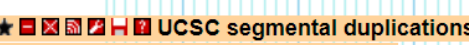

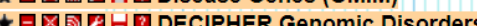

Na figura A, observamos a localização do ganho na sub-banda q21.1 do cromossomo X, envolvendo o gene $C O X 7 B$. Na figura B, um recorte da análise desse ganho pelo DGV evidenciando que essa variante é considerada rara (sem descrição anterior). A linha na cor rosa demonstra a presença do gene $C O X 7 B$ 
Figura 23 - CNV do tipo ganho, compartilhada por indivíduos de grupo amostral e localizada em 17q21.33
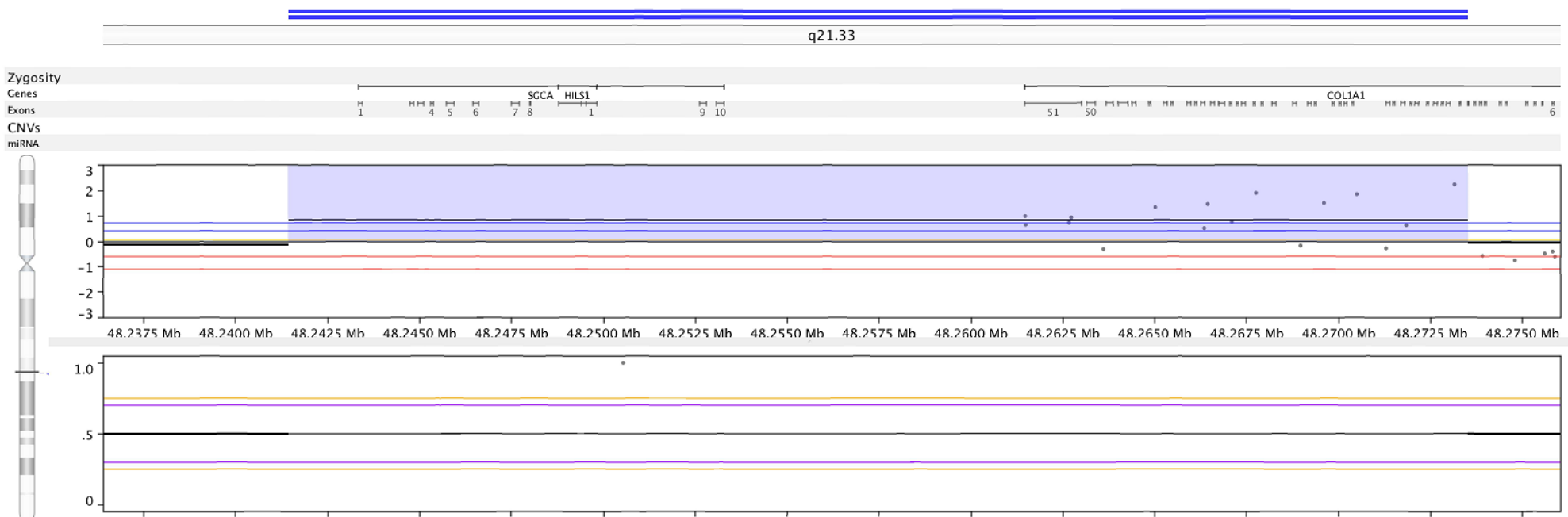

US09523754_252983037504_S01_CCH_1200_Jun14_1_3: Chromosome 17

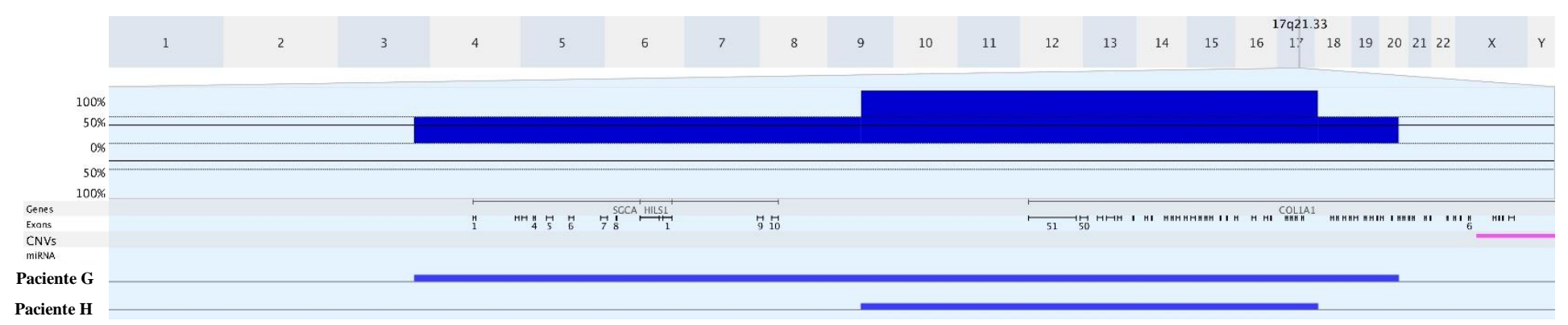

Na figura A, observamos a localização e a extensão do ganho no braço longo do cromossomo 17. Na figura B, visualizamos que o ganho foi compartilhado pelos pacientes $\mathrm{G}$ e H e que a região de interseção compreendia parte do gene COL1A1. 


\subsubsection{Distribuição e comparação entre grupos das Variantes de Número de Cópias do tipo perda}

O total de variantes de número de cópias do tipo perda observado na população em estudo foi de 35, sendo 6 perdas no grupo controle e 29 no grupo infértil. Para esse tipo de $\mathrm{CNV}$, o grupo amostral apresentou cerca do dobro de alterações por indivíduo $(1,8)$ quando comparado com grupo controle (1). Apenas dois indivíduos do grupo controle (C1 e C2) apresentaram perdas no seu genoma, sendo que $\mathrm{C} 2$ concentrou 5 tipos diferentes de perdas (Tabela 4, página 76).

A distribuição desse tipo de CNV nos diferentes cromossomos revelou que nenhuma perda foi detectada em 11 cromossomos: 1, 5, 9, 11, 16, 17, 18, 19, 20, 21 e Y. Os cromossomos 2, 3, 6, 7, 13, 22 e X apresentaram perdas apenas no grupo amostral, enquanto que nos cromossomos 10, 12 e 14 as perdas ficaram restritas ao grupo controle. Não foram detectadas deleções em nenhum dos cromossomos sexuais no grupo controle (Figura 19).

Análise mais detalhada desse tipo de alteração revelou que duas perdas foram compartilhadas por indivíduos do grupo controle e amostral, enquanto que três perdas foram detectadas apenas entre indivíduos do grupo controle. Dessa forma, essas cinco alterações não foram consideradas relevantes. Além disso, 14 deleções foram detectadas apenas no grupo amostral, sendo 11 individuais e 3 compartilhadas. Dessas 11 deleções individuais, 5 foram excluídas por não serem codificantes de proteína, assim como a deleção compartilhada em Xp22.33. Dessa forma, restaram 6 perdas individuais e 2 compartilhadas que foram analisadas no DGV (Figura 24).

A tabela 7 descreve as $6 \mathrm{CNVs}$ do tipo perda caracterizadas como restritas, individuais e codificantes de proteínas. Elas apresentaram variação de tamanho de $116 \mathrm{~kb}$ a $667 \mathrm{~kb}$ e estavam localizadas exclusivamente em autossomos. Após análise no DGV, apenas a perda detectada em 3p21.2-21.31 foi considerada rara. Essa alteração, com $227 \mathrm{~kb}$ de tamanho, contém os genes CACNA2D2, C3orf18, HEMK1, CISH e MAPKAPK3 (Figura 25).

Na tabela 8 estão descritas as duas perdas que foram caracterizadas como restritas, compartilhadas e codificantes de proteínas. A sub-banda q11.2 do cromossomo 15 foi compartilhada por quase metade dos pacientes com azoospermia não obstrutiva. Apresentava tamanho de cerca de $331 \mathrm{~kb}$ e incluía 2 genes codificantes de proteínas do grupo dos receptores olfatórios (OR4M2 e OR4N4). No entanto, após análise no DGV, essa 
variante foi considerada como uma variante comum (Figura 26). Já a deleção na sub-banda q21.1 do cromossomo 2, de 3,7kb, foi compartilhada por dois indivíduos do grupo amostral e continha apenas um gene codificante de proteína (DLXI) (Figura 27). 
Figura 24 - Fluxograma da distribuição das CNVs do tipo perda

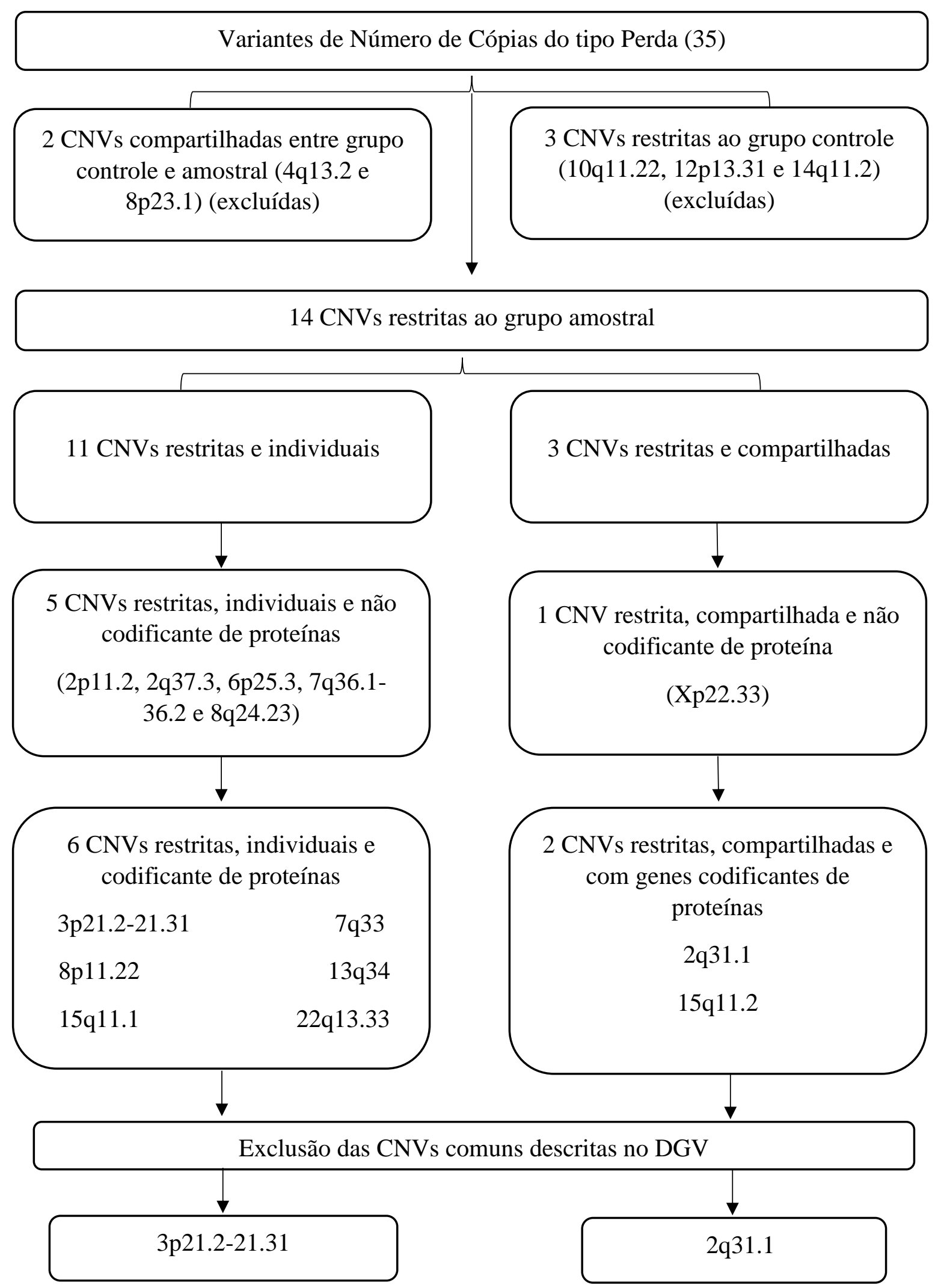


Tabela 7 - CNVs do tipo perda, restritas, individuais e codificantes de proteína

\begin{tabular}{|c|c|c|c|c|}
\hline Cromossomo & Banda & $\begin{array}{c}\text { Posição } \\
\text { Genômica }\end{array}$ & Tamanho & Genes \\
\hline 3 & $\mathrm{p} 21.2-21.31$ & $\begin{array}{l}50,436,577- \\
50,663,730\end{array}$ & $227 \mathrm{~kb}$ & CACNA2D2, C3orf18, HEMK1, CISH, МАРКАРК3 \\
\hline 7 & q33 & $\begin{array}{c}133,170,401- \\
133,647,334\end{array}$ & $476 \mathrm{~kb}$ & EXOC4, LOC 101928861 \\
\hline 8 & $\mathrm{p} 11.22$ & $\begin{array}{l}39,240,660- \\
39,393,247\end{array}$ & $152 \mathrm{~kb}$ & $A D A M 5, A D A M 3 A$ \\
\hline 13 & q34 & $\begin{array}{l}115,053,229- \\
115,169,878\end{array}$ & $116 \mathrm{~kb}$ & UPF3A, CHAMP1, LINC01054 \\
\hline 15 & q11.1 & $\begin{array}{l}20,493,386- \\
21,161,327\end{array}$ & $667 \mathrm{~kb}$ & $\begin{array}{c}\text { CHEK2P2, HERC2P3, GOLGA6L6, GOLGA8CP, NBEAP1, MIR3118- } \\
\text { 2, MIR3118-3, MIR3118-4, POTEB2, POTEB, POTEB3, NF1P2, } \\
\text { MIR5701-1, MIR5701-2, MIR5701-3, LINC01193 }\end{array}$ \\
\hline 22 & q13.33 & $\begin{array}{l}51,160,665- \\
51,304,566\end{array}$ & $143 \mathrm{~kb}$ & SHANK3, LOC105373100, ACR, RABL2B, RPL23AP82 \\
\hline
\end{tabular}


Tabela 8 - CNVs do tipo perda, restritas, compartilhadas e codificantes de proteína

\begin{tabular}{|c|c|c|c|c|c|}
\hline Cromossomo & Banda & Posição Genômica & Tamanho & $\mathbf{N}^{\circ}$ de indivíduos & Genes \\
\hline 2 & $\mathrm{q} 31.1$ & $172,948,765-172,952,539$ & $3,7 \mathrm{~kb}$ & 2 & $D L X 1$ \\
\hline 15 & q11.2 & $22,297,051-22,628,639$ & $331 \mathrm{~kb}$ & 7 & $\begin{array}{c}\text { LINC02203, LOC101927079, OR4M2, } \\
\text { OR4N4, OR4N3P, LOC102724760, } \\
\text { IGHV1OR15-1, LOC642131, } \\
\text { IGHVIOR15-3, MIR1268A, REREP3 }\end{array}$ \\
\hline
\end{tabular}


Figura 25 - CNV do tipo perda detectada em 3p21.2-21.31 em paciente com azoospermia não obstrutiva

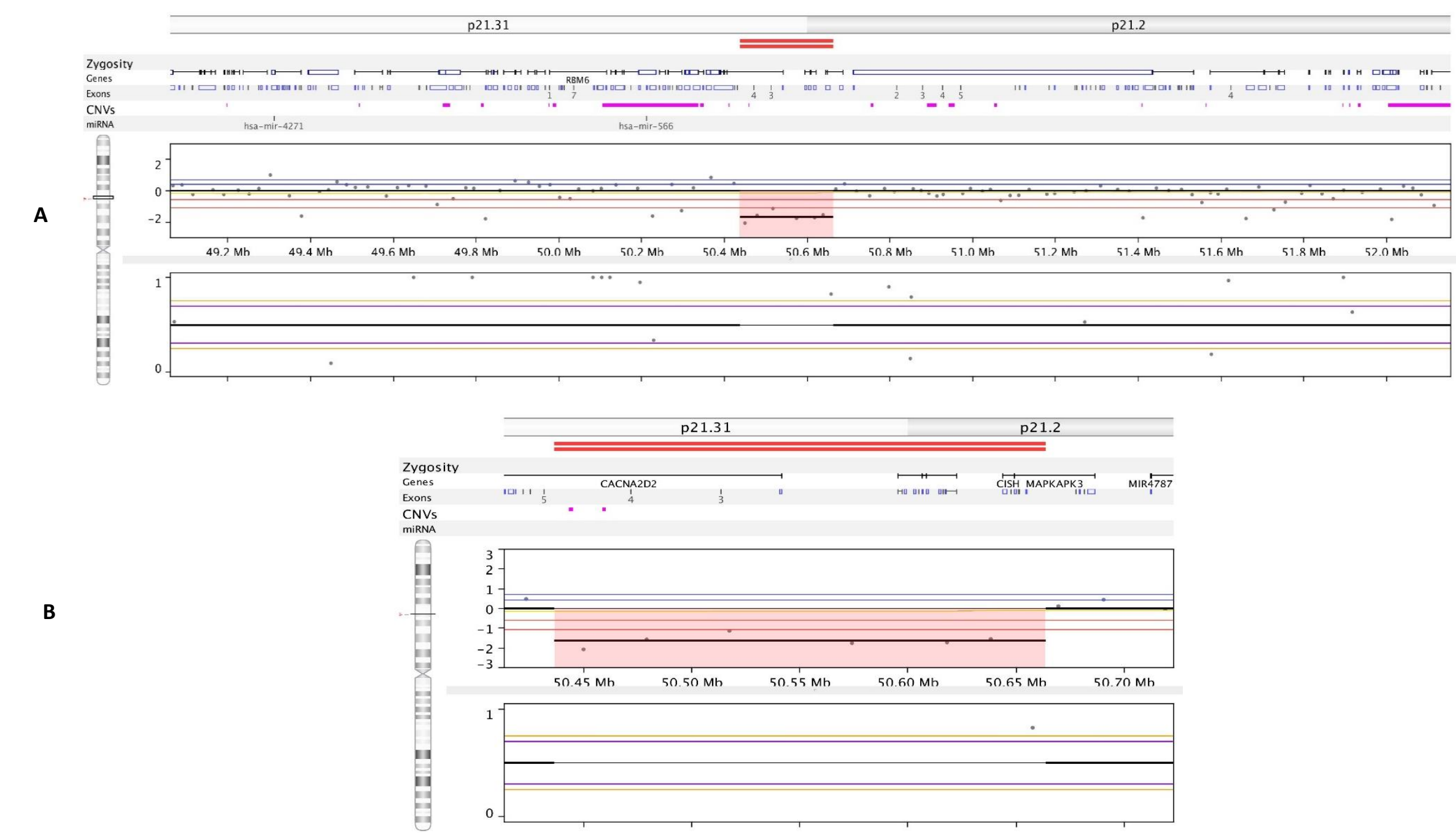

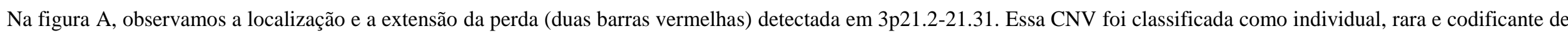
proteína. Na figura B, detalhamento dos genes CACNA2D2, C3orf18, HEMK1, CISH, MAPKAPK3 localizados nessa região. 
Figura 26 - CNV do tipo perda, compartilhada e codificante de proteína detectada em 15q11.2

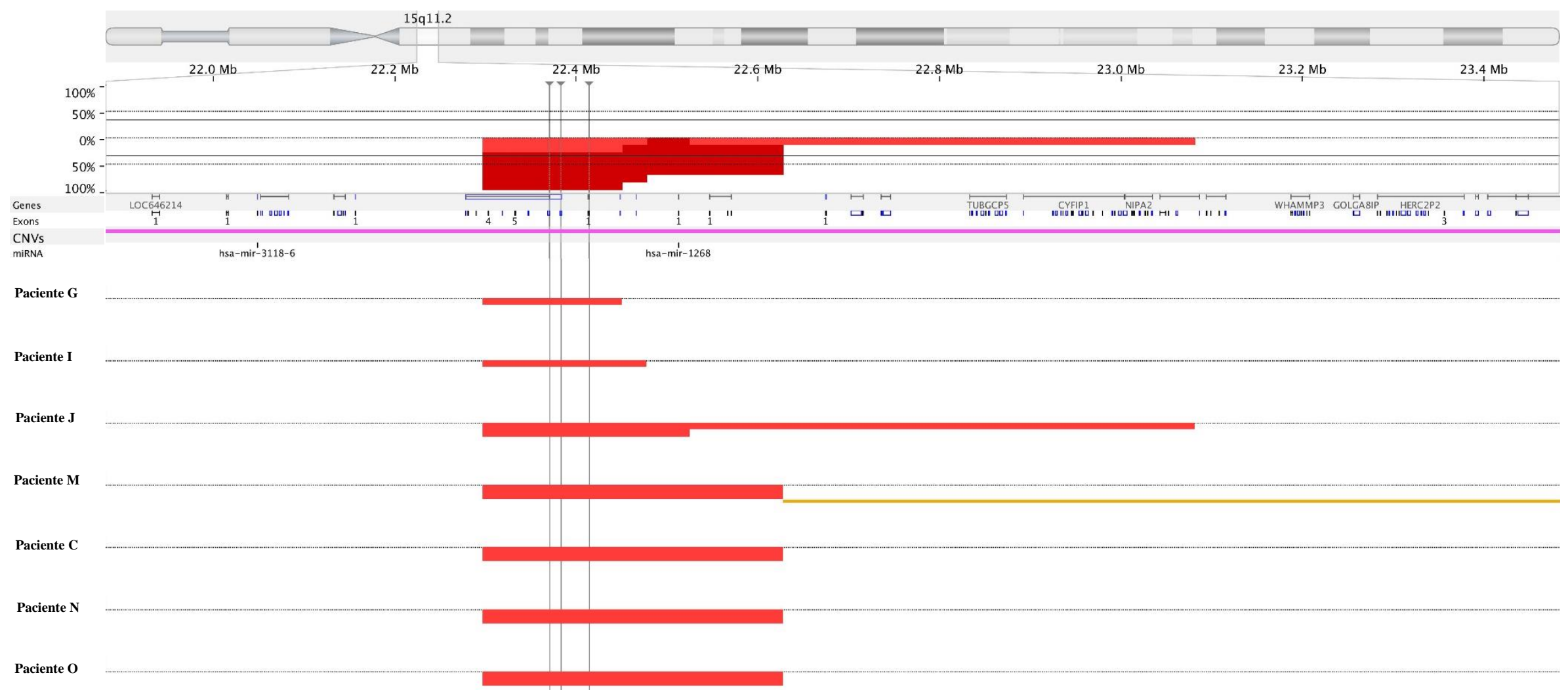

Essa perda foi detectada apenas no grupo amostral (restrita) e foi compartilhada por 7 diferentes pacientes (G, I, J, M, C, N e O). As deleções são representadas pelas barras vermelhas localizadas abaixo da linha principal. Observamos diferentes tamanhos dessa deleção, porém a sua interseção foi demarcada pelas linhas verticais que representam, da esquerda para a direita, os genes $O R 4 M 2$ e $O R 4 N 4$ e o pseudogene $O R 4 N 3 P$. 
Figura 27 - CNV do tipo perda, compartilhada e codificante de proteína detectada em 2q31.1

A

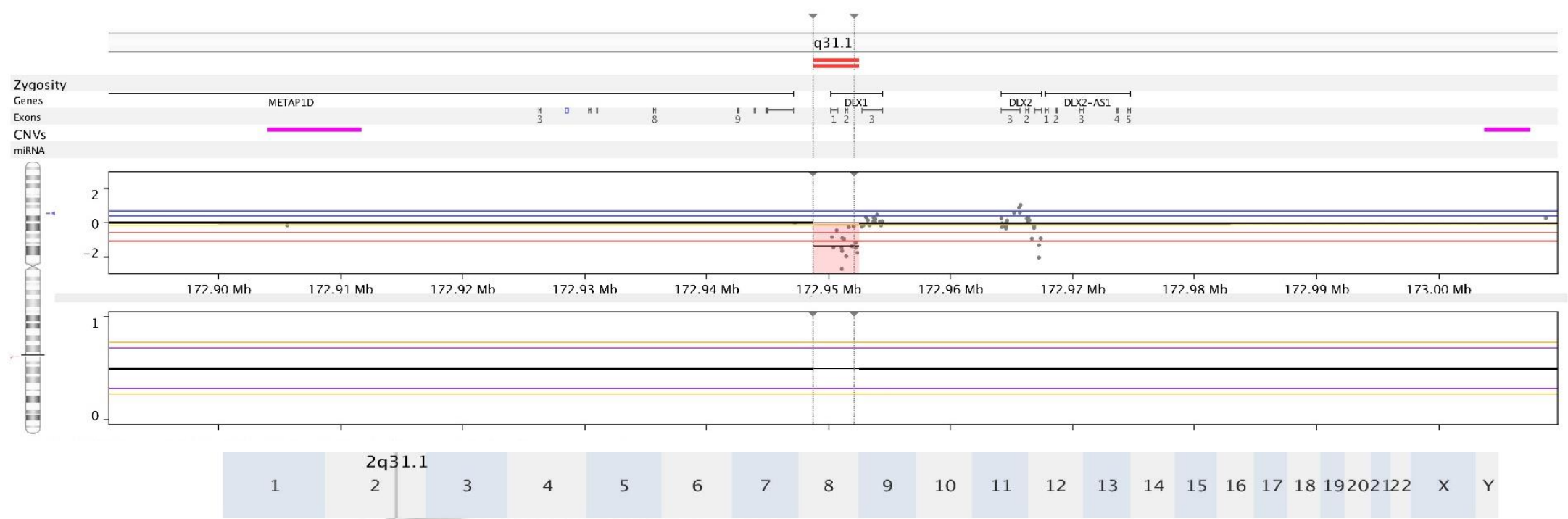

B

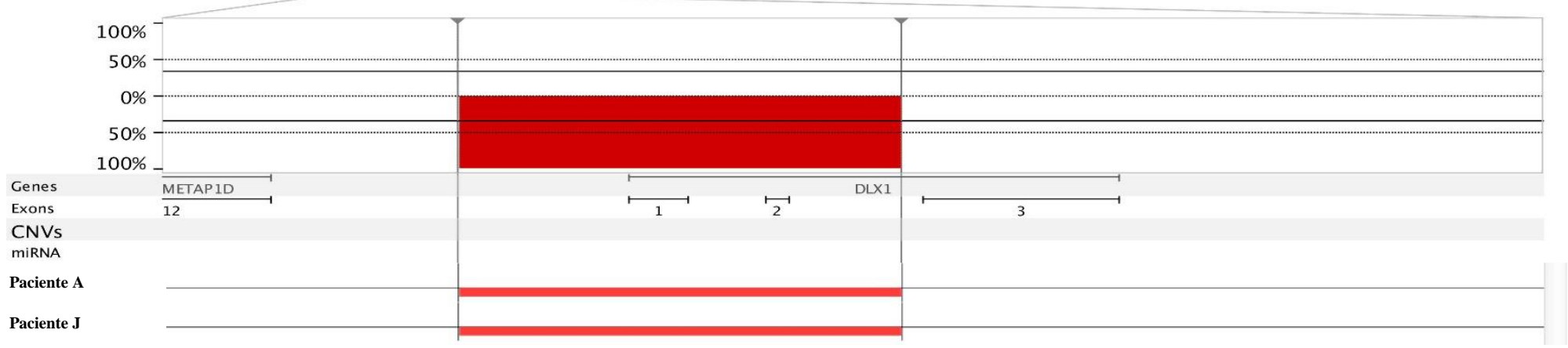

Na figura A, observamos a localização e a extensão da perda (duas barras vermelhas) no braço longo do cromossomo 2. Em B, observamos que essa deleção foi compartilhada pelos indivíduos A e J e continha o gene $D L X 1$. 


\subsubsection{Distribuição e comparação entre grupos das Variantes de Número de Cópias localizadas no cromossomo $\mathrm{Y}$}

Uma análise individualizada do cromossomo $\mathrm{Y}$ foi realizada devido a suas particularidades como conteúdo gênico, voltado para a regulação da espermatogênese, estrutura genômica e relevância sobre o fenótipo de infertilidade masculina.

Todas as $12 \mathrm{CNVs}$ descritas nesse cromossomo foram do tipo ganho, sendo 7 no grupo de pacientes com azoospermia e 5 no grupo controle. Essas CNVs estavam localizadas em três diferentes sub-bandas do cromossomo Y, sendo, respectivamente, uma no braço curto (Yp11.2) e duas no braço longo, envolvendo as regiões de AZF (Yq11.222 e Yq11.223) (Tabela 9).

Um ganho de $106 \mathrm{~kb}$ foi detectado na sub-banda $\mathrm{p} 11.2$ do cromossomo $\mathrm{Y}$ (paciente A). Essa variante não havia sido descrita no DGV. Não há descrição de gene codificante de proteína nessa $\mathrm{CNV}$, mas sim a presença de um gene codificante de um RNA intergênico longo de função desconhecida (LINC00279) (Figura 28).

Foram observados dois diferentes ganhos na sub-banda q11.222 do cromossomo Y. Um ganho menor, de $10 \mathrm{~kb}$, identificado no paciente "O" e contendo os genes $C D Y 2 A$ e CDY2B e um outro maior, de 489kb, contendo os genes FAM224A, FAM224B, FAM41AY1, FAM41AY2, HSFY2, HSFY1, TTTY9A, TTTY9B, no controle 6 (C6). Esses ganhos são reconhecidos como variantes comuns no DGV e os genes descritos participam da regulação da espermatogênese (Figura 28).

Quatro indivíduos do grupo controle (C1, C2, C3 e C5) apresentaram ganhos com pequena variação de tamanho $(11-16 \mathrm{~kb})$ e que incluíam os genes $D A Z 1$ e $D A Z 4$ na subbanda q11.223. Essa mesma alteração foi compartilhada por três indivíduos do grupo amostral $(\mathrm{H}, \mathrm{K}$ e $\mathrm{M})$. Os indivíduos $\mathrm{G}$ e $\mathrm{O}$ também apresentaram ganhos na região de Yq11.223, porém essas alterações foram bem maiores $(>1 \mathrm{Mb})$ e com diferente conteúdo gênico. Os ganhos nessa região estão descritos no DGV como variantes comuns e os genes envolvidos também regulam o processo de espermatogênese (Figura 28). 
Tabela 9 - CNVs detectadas no cromossomo Y

\begin{tabular}{|c|c|c|c|c|}
\hline $\begin{array}{c}\text { Sub- } \\
\text { banda }\end{array}$ & Indivíduos & $\begin{array}{c}\text { Posição } \\
\text { genômica }\end{array}$ & Tamanho & Genes \\
\hline p11.2 & A & $\begin{array}{l}8,406,069- \\
8,512,073\end{array}$ & $106 \mathrm{~kb}$ & LINC00279 \\
\hline 11222 & $\mathrm{O}$ & $\begin{array}{c}19,980,561- \\
19,991,314\end{array}$ & $10 \mathrm{~kb}$ & $C D Y 2 B, C D Y 2 A$ \\
\hline & C6 & $\begin{array}{c}20,344,234- \\
20,834,004\end{array}$ & $489 \mathrm{~kb}$ & FAM224A, FAM224B, FAM41AY1, FAM41AY2, HSFY2, HSFY1, TTTY9A, TTTY9B \\
\hline \multirow{5}{*}{$\mathbf{q 1 1 . 2 2 3}$} & $\begin{array}{l}\mathrm{C} 3 \\
\mathrm{M}\end{array}$ & $\begin{array}{c}25,297,250- \\
25,308,750\end{array}$ & $11 \mathrm{~kb}$ & $D A Z 1, D A Z 4$ \\
\hline & $\mathrm{C} 1$ & $\begin{array}{c}25,292,630- \\
25,306,798\end{array}$ & $14 \mathrm{~kb}$ & $D A Z 1, D A Z 4$ \\
\hline & $\begin{array}{c}\mathrm{C} 2 \\
\mathrm{C} 5 \\
\mathrm{H} \\
\mathrm{K}\end{array}$ & $\begin{array}{c}25,292,630- \\
25,308,750\end{array}$ & $16 \mathrm{~kb}$ & $D A Z 1, D A Z 4$ \\
\hline & $\mathrm{G}$ & $\begin{array}{c}24,819,599- \\
26,381,366\end{array}$ & $1,5 \mathrm{Mb}$ & $\begin{array}{c}\text { TTTY17A, TTTY17B, TTTY17C, DAZ1, DAZ4, DAZ3, DAZ4, DAZ2, TTTY3B, TTTY3, } \\
\text { CDY1, CDY1B, CSPG4P1Y, GOLGA2P2Y, GOLGA2P3Y }\end{array}$ \\
\hline & $\mathrm{O}$ & $\begin{array}{l}24,803,880- \\
26,271,609\end{array}$ & $1,4 \mathrm{Mb}$ & $\begin{array}{l}\text { TTTY17A, TTTY17B, TTTY17C, TTTY4B, TTTY4C, TTTY4, ВPY2, ВРY2B, ВРY2C, } \\
D A Z 1, D A Z 4, D A Z 1, D A Z 4, D A Z 3, D A Z 4, D A Z 2, T T T Y 3 B, T T T Y 3, C D Y 1, C D Y 1 B\end{array}$ \\
\hline
\end{tabular}




\section{Figura 28- CNVs do tipo ganho detectadas no cromossomo Y}

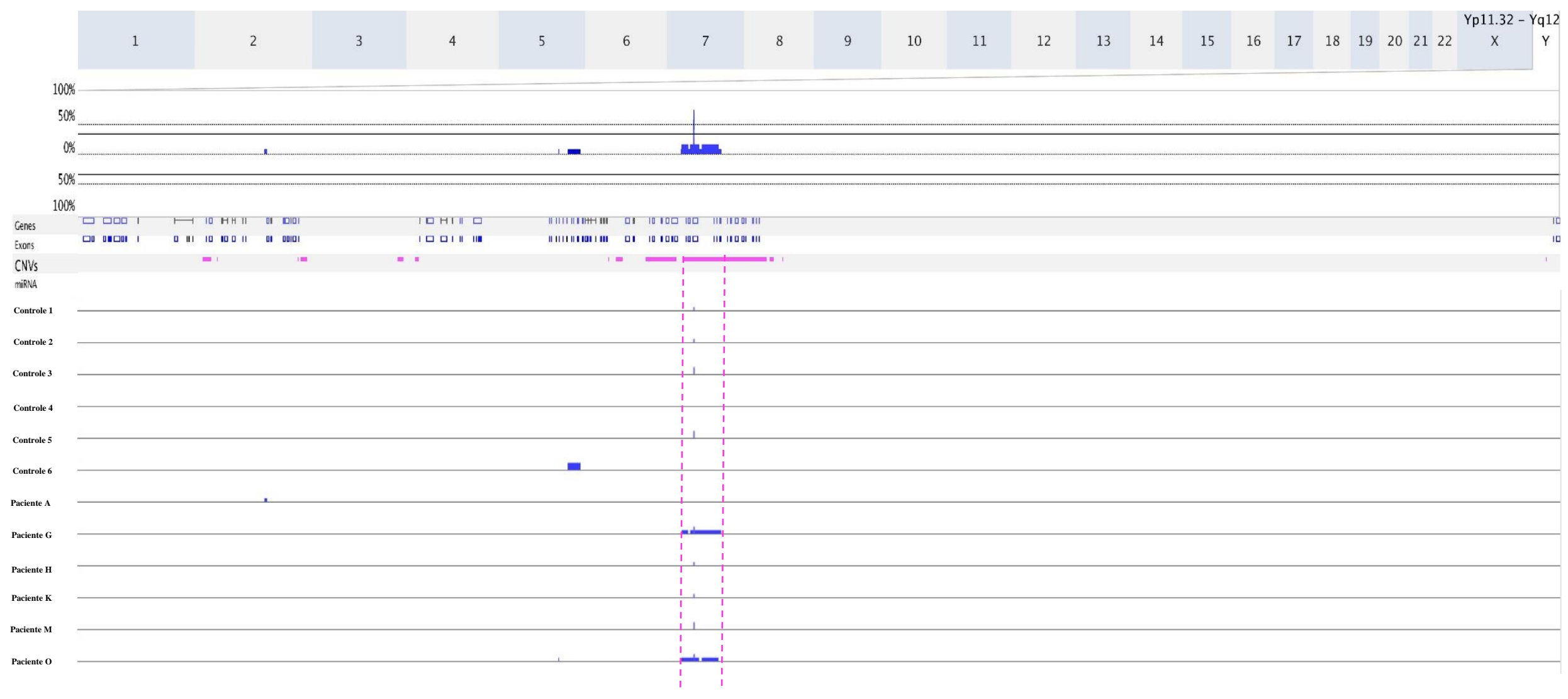

A figura demonstra a presença das CNVs do tipo ganho (barras azuis) em indivíduos do grupo controle (C1, C2, C3, C5 e C6) e do grupo amostral (A, G, H, K, M e O). Observamos que a CNV detectada na sub-banda q11.223 foi compartilhada pelos controles C1, C2, C3 e C5 e pelos pacientes G, H, K, M e O e apresentava variação de tamanho. Esses ganhos estão localizados numa região de CNV comum (barra rosa localizada na região superior da figura e delimitada pelas linhas pontilhadas). O controle 6 apresentou um ganho na sub-banda q11.222 que não se sobrepõe ao pequeno ganho, na mesma região, evidenciado pelo paciente $\mathrm{O}$ (pequena linha vertical azul). A figura ainda demonstra o ganho na sub-banda Yp11.2, detectada no paciente A e sem descrição no DGV. 


\subsubsection{Distribuição e comparação entre grupos das regiões de perda de heterozigosidade $(\mathrm{LOH})$}

Um total de 94 regiões de perdas de heterozigosidade foram observadas em ambos os grupos analisados, sendo 27 no grupo controle e 67 no amostral. Não foi observada diferença significativa entre a média desse tipo de alteração pelo número de indivíduos em cada grupo (4,5 x 4,18, respectivamente) (Tabela 4, página 76).

As LOHs foram divididas, de acordo com o seu tamanho, em dois grupos: $1-2,9 \mathrm{Mb}$ e > 3Mb. Não foram observadas diferenças significativas quanto ao tamanho dessas regiões e a média de indivíduos em ambos os grupos (Figura 29).

A distribuição das regiões de perda de heterozigosidade entre os diferentes cromossomos evidenciou que quase todas as LOHs foram observadas em autossomos. Apenas um indivíduo do grupo controle apresentou uma alteração de 2,3Mb em Xq28. Os cromossomos 14, 17, 22 e Y não apresentaram LOHs em ambos os grupos, enquanto que LOHs restritas ao grupo amostral foram detectadas nos cromossomos 6, 15, e 21. LOHs restritas ao grupo controle foram observadas nos cromossomos 19 e X (Figura 30).

Uma análise comparativa entre o grupo controle e o de pacientes com azoospermia não obstrutiva evidenciou que 8 regiões de $\mathrm{LOH}$ foram compartilhadas entre os dois grupos e que 16 LOHs foram restritas ao grupo controle. No grupo amostral, 37 dessas alterações foram individuais, enquanto que 6 foram descritas em mais de um indivíduo. Dessas 6 regiões de perda de heterozigose, restritas ao grupo amostral e compartilhadas, 3 apresentam genes potencialmente associados à infertilidade (1p31.1, 7q21.1 e 12q21.1-21.2) e foram consideradas mais relevantes para análise (Figura 31).

A tabela 10 resume a localização, posição genômica, tamanho, genes codificantes de proteínas e número de indivíduos que compartilharam 3 regiões de perda de heterozigose entre os pacientes com azoospermia não obstrutiva. 
Figura 29 - Distribuição do tamanho das regiões de LOH pela média de indivíduos no grupo amostral e controle

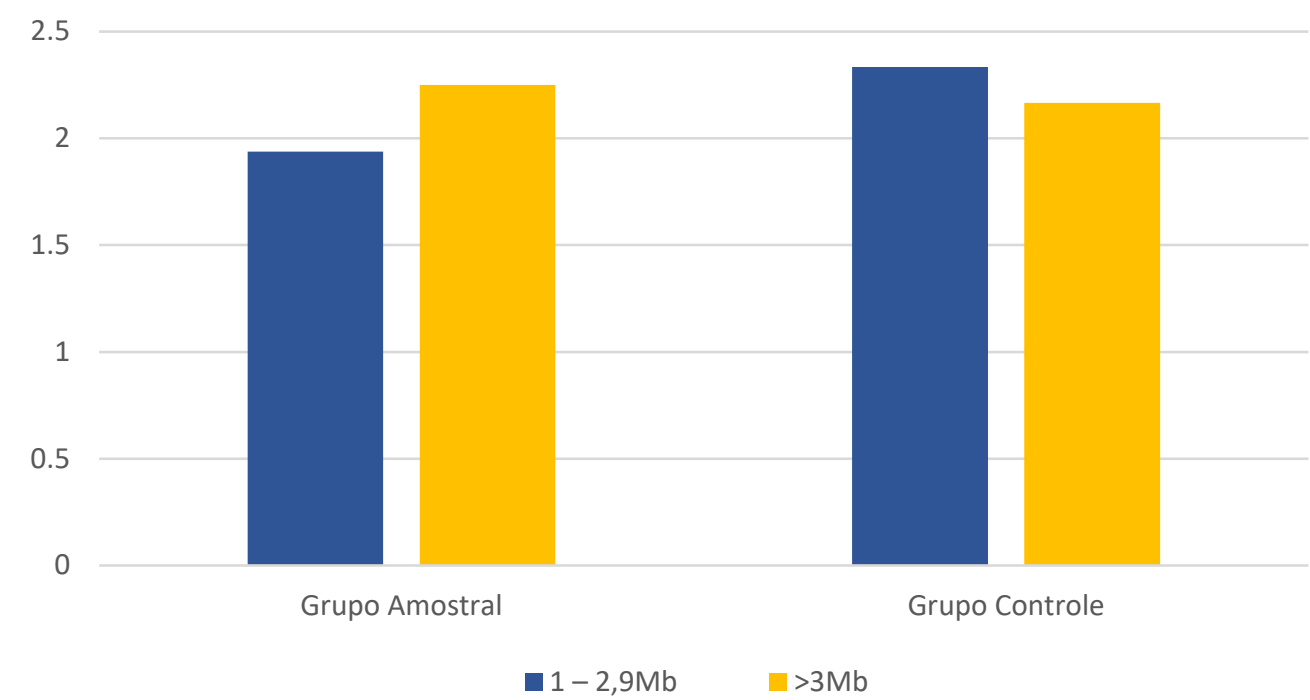

Figura 30 - Distribuição das regiões de perda de heterozigose (LOH), pela média de indivíduos nos grupos amostral e controle, nos diferentes cromossomos

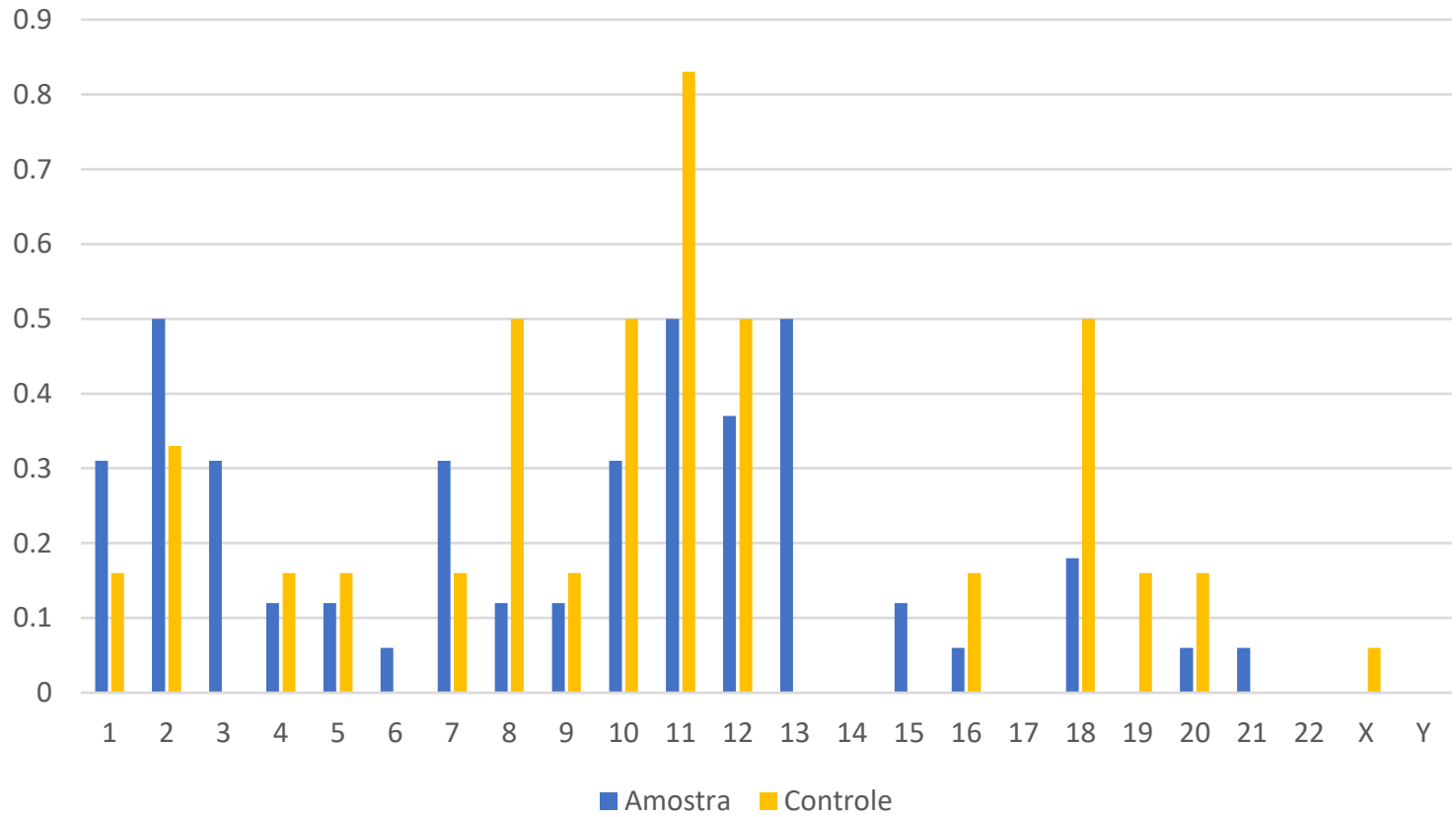


Figura 31 - Fluxograma da distribuição das regiões de LOH

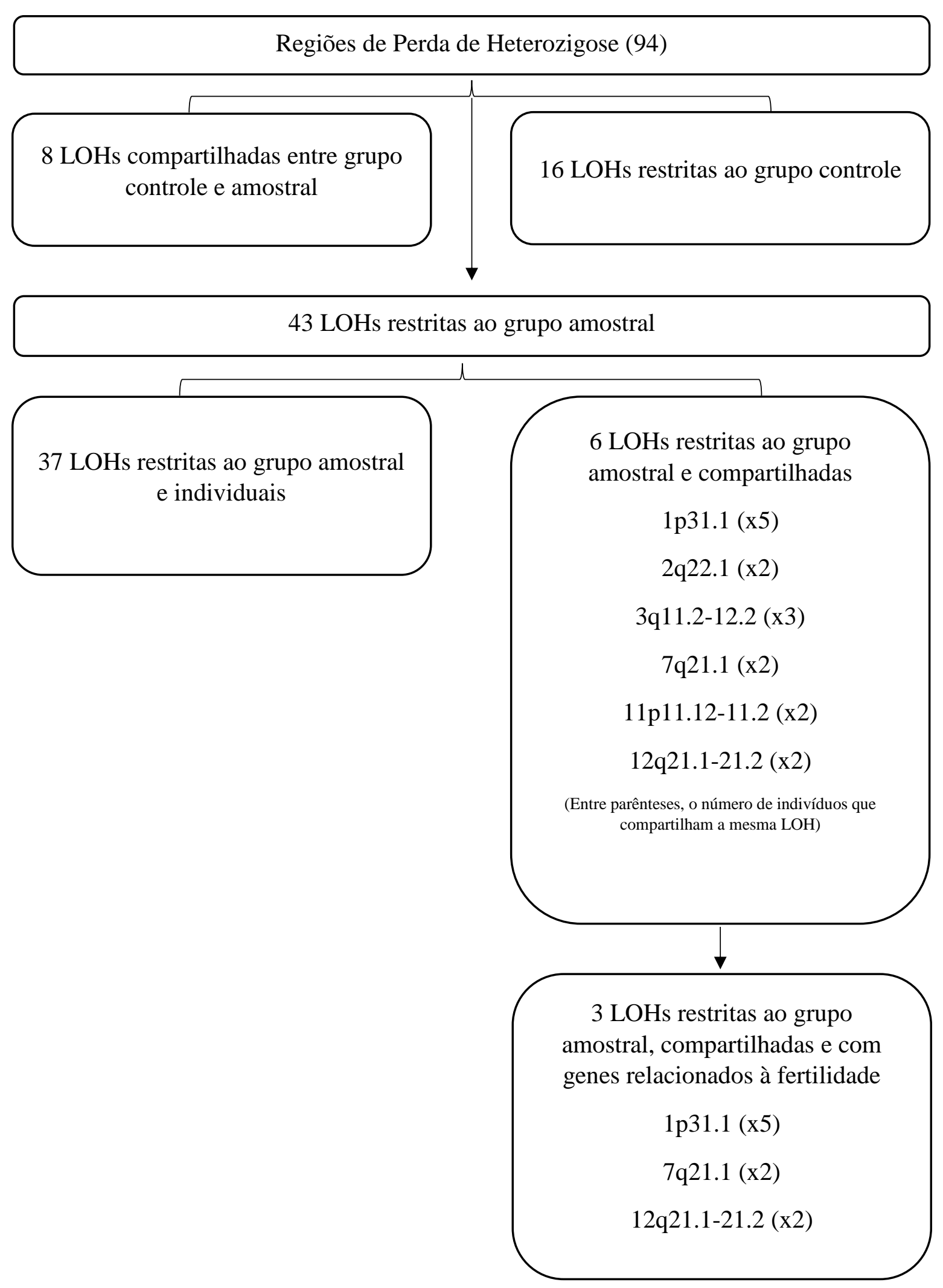


Tabela 10 - Regiões de LOH restritas, compartilhadas entre indivíduos do grupo amostral e que apresentavam genes relacionados à fertilidade (Continua)

\begin{tabular}{|c|c|c|c|c|c|c|c|}
\hline Cromossomo & Banda & $\begin{array}{c}\text { Posição } \\
\text { Genômica }\end{array}$ & Tamanho & $\begin{array}{c}\mathbf{N}^{\circ} \text { de } \\
\text { indivíduos }\end{array}$ & Genes & Genes codificantes & $\begin{array}{c}\text { Genes } \\
\text { codificantes e } \\
\text { associados à } \\
\text { infertilidade }\end{array}$ \\
\hline
\end{tabular}

$1 \quad \mathrm{p} 31.1 \quad \begin{array}{ll}70,080,248- \\ 74,013,952\end{array} \quad 3,9 \mathrm{Mb}$

\section{5}

LRRC7, PINIP1,

LRRC40, SRSF11

ANKRD13C, HHLA3, LRRC7, LRRC40,

CTH, LINC01788, SRSF11, ANKRD13C, LRRC7 e

PTGER3, ZRANB2-AS1, CTH, PTGER3, LRRC40

MIRI86, ZRANB2, NEGRI

ZRANB2-AS2, NEGR1-

IT1, NEGR1, LINC01360 
Tabela 10 - Regiões de LOH restritas, compartilhadas entre indivíduos do grupo amostral e que apresentavam genes relacionados à fertilidade (Continuação)

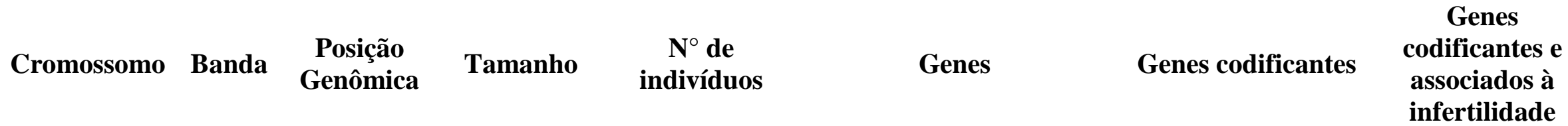

$\mathrm{q} 21.1 \quad 78,881,218-\quad 7,8 \mathrm{Mb}$

2
MAGI2, MAGI2-AS3,

GNAI1, LOC101927269, GNAT3, CD36,

SEMA3C,

LOC105369146, LOC100128317, HGF, LOC101927356, CACNA2D1, PCLO, SEMA3E, SEMA3A, LOC101927378,

SEMA3D, LINC00972,

GRM3, KIAA1324L
MAGI2, GNAII,

GNAT3, CD36,

SEMA3C, HGF,

CACNA2D1, PCLO,

SEMA3E, SEMA3A,

SEMA3D GRM3,

KIAA1324L
SEMA3C e

SEMA3D 
Tabela 10 - Regiões de LOH restritas, compartilhadas entre indivíduos do grupo amostral e que apresentavam genes relacionados à fertilidade (Conclusão)

\begin{tabular}{|c|c|c|c|c|c|c|c|}
\hline Cromossomo & Banda & $\begin{array}{c}\text { Posição } \\
\text { Genômica }\end{array}$ & Tamanho & $\begin{array}{c}\mathbf{N}^{\circ} \text { de } \\
\text { indivíduos }\end{array}$ & Genes & Genes codificantes & $\begin{array}{c}\text { Genes } \\
\text { codificantes e } \\
\text { associados à } \\
\text { infertilidade }\end{array}$ \\
\hline
\end{tabular}

12

$\begin{array}{cc}\mathrm{q} 21.1- & 71,907,062- \\ 21.2 & 80,700,192\end{array}$

$8,7 \mathrm{Mb}$

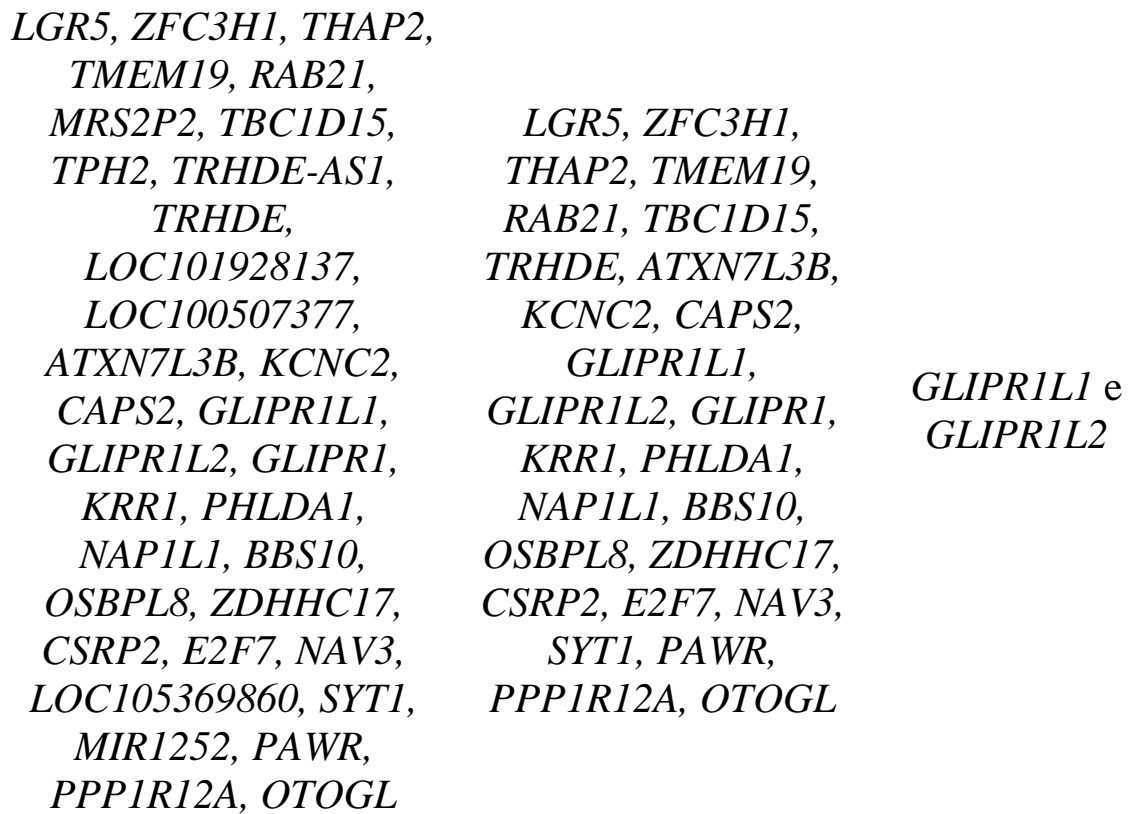

\section{LGR5, ZFC3H1,} THAP2, TMEM19, RAB21, TBC1D15,

TRHDE, ATXN7L3B, KCNC2, CAPS2, GLIPRIL1, GLIPR1L2, GLIPR1, KRR1, PHLDA1,

NAPIL1, BBS10, OSBPL8, ZDHHC17, CSRP2, E2F7, NAV3, SYT1, PAWR, PPPIRI2A, OTOGL 
Figura 32 - LOH restrita ao grupo amostral, compartilhada e com genes codificantes de proteína detectada em 1p31.1

A
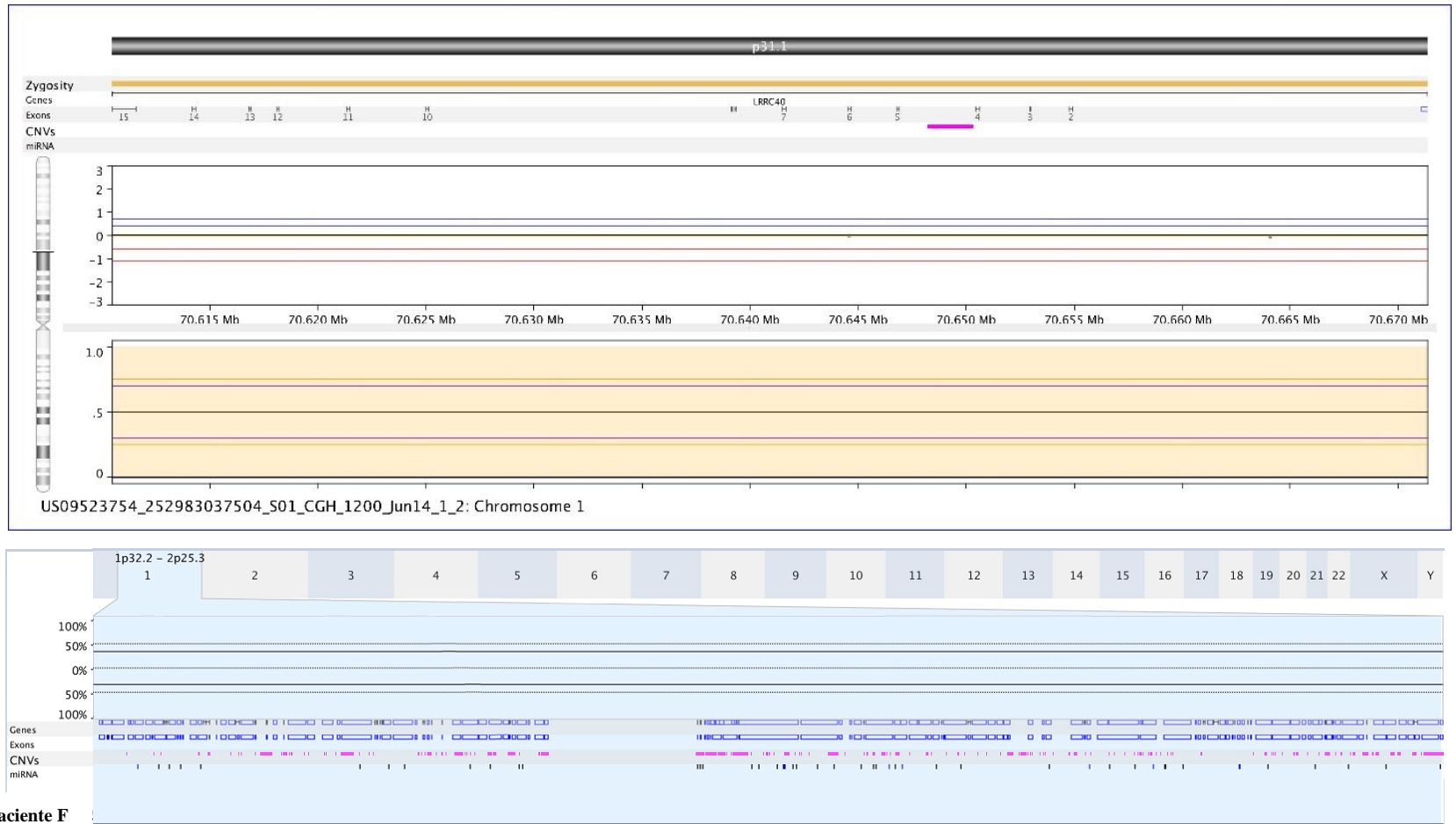

B

$$
\text { Paciente F }
$$

Paciente G

Paciente K

$-$

Paciente

Paciente $\mathrm{O}$

A figura A demonstra a localização e a extensão da LOH detectada na sub-banda p31.1 do cromossomo 1 (barra rosa). Em B, observamos que essa alteração foi compartilhada por cinco indivíduos do grupo amostral (barras em laranja). 
Figura 33 - LOH restrita ao grupo amostral, compartilhada e com genes codificantes de proteína detectada em 7q21.1

A
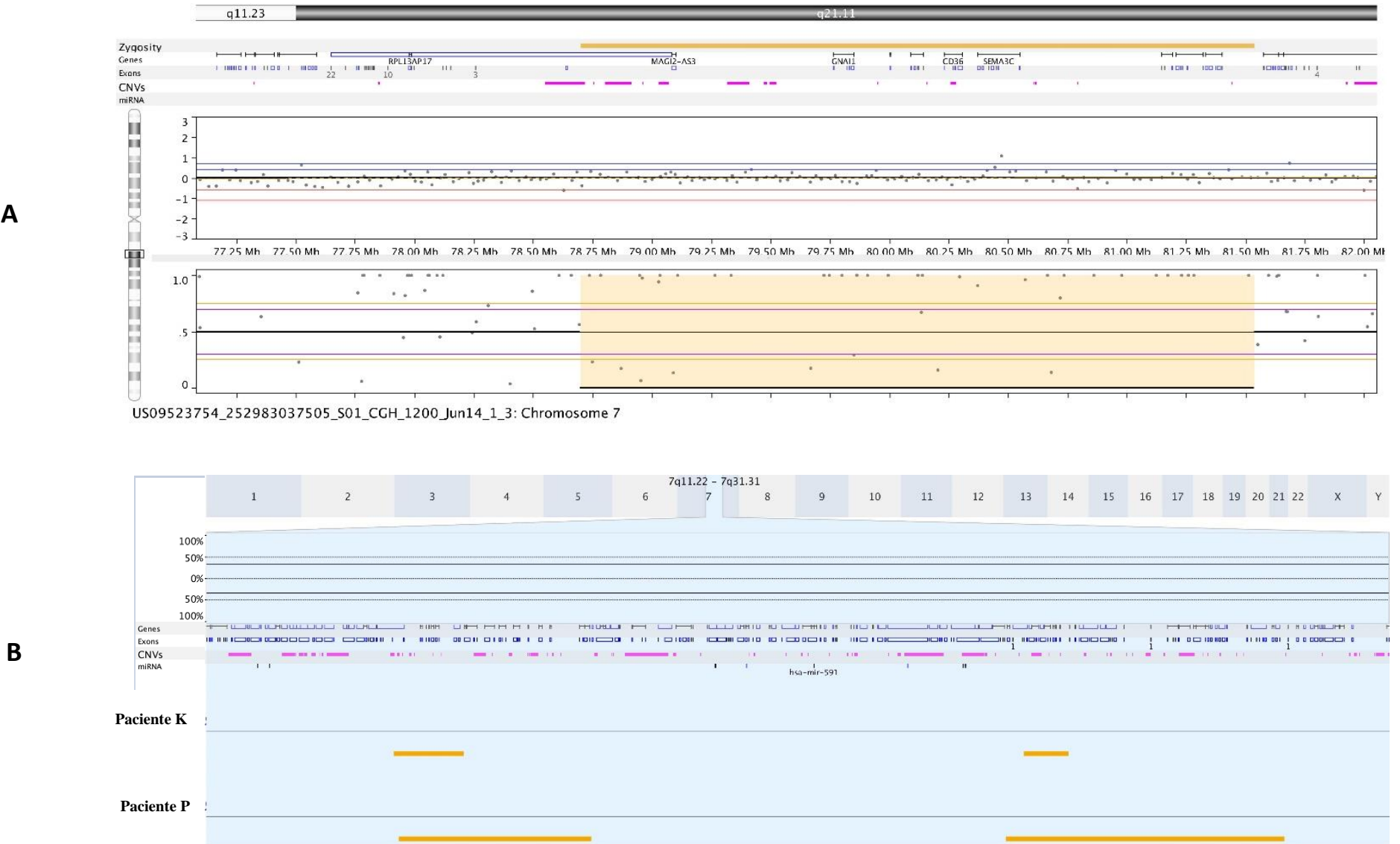

A figura A demonstra a localização e a extensão da LOH detectada na sub-banda q21.1 do cromossomo 7 (barra em laranja). Em B, observamos que essa alteração foi compartilhada por 2 indivíduos do grupo amostral. 
Figura 34 - LOH restrita ao grupo amostral, compartilhada e com genes codificantes de proteína detectada em 12q21.1-21.2

A

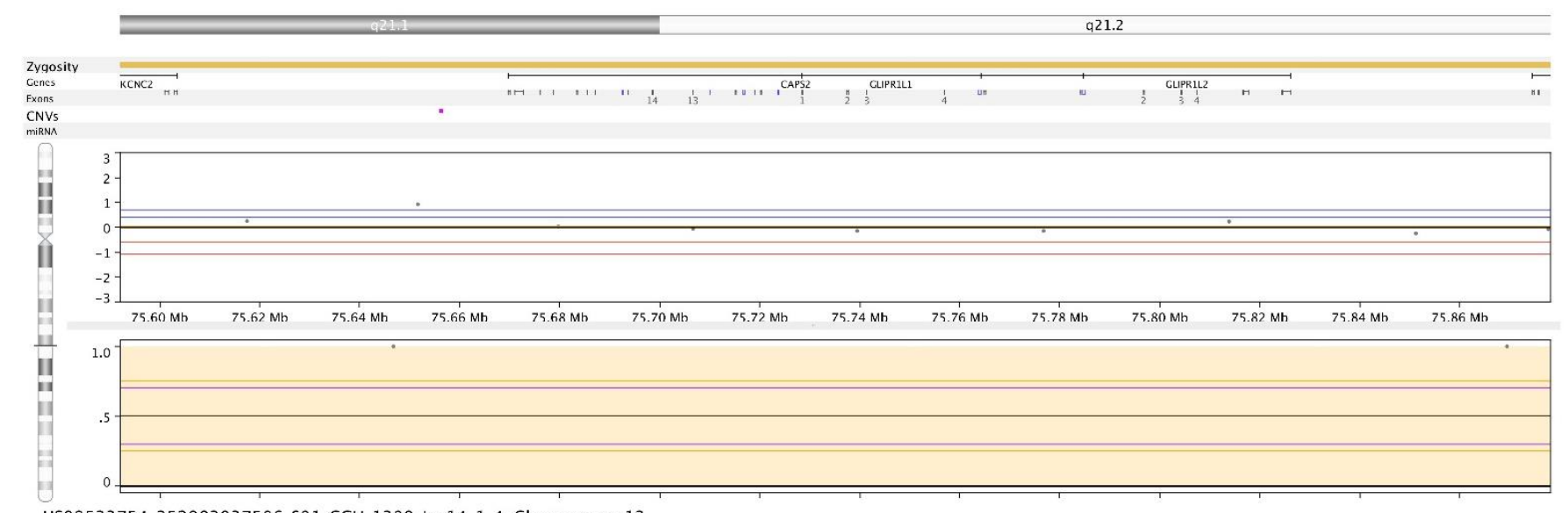
US09523754_252983037506_S01_CCH_1200_un14___4: Chromosome 12

B

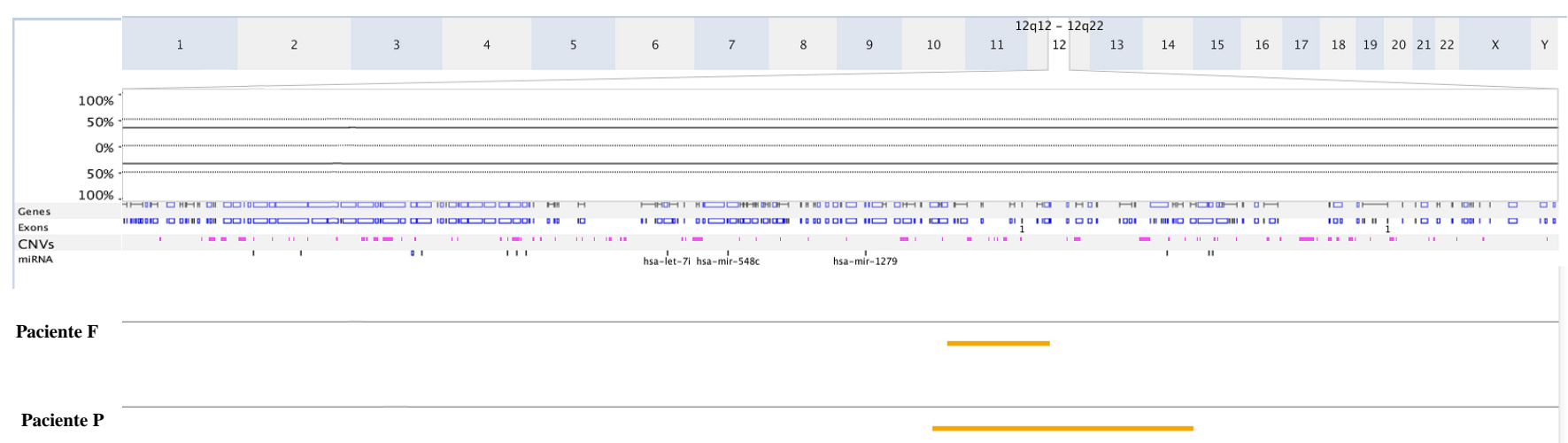

A figura A demonstra a localização e a extensão da LOH identificada na sub-banda q21.1-21.2 do cromossomo 12 (barra em laranja). Em B, observamos que essa alteração foi compartilhada por 2 indivíduos do grupo amostral. Essa região contém os genes GLIPRIL1 e GLIPRIL2. 


\section{DISCUSS ÃO}

As horas perderam seu relógio

Vicente Huidobro 


\section{DISCUSSÃO}

A infertilidade conjugal é um problema de saúde pública que tem implicações psicológicas, estigmatização social e técnicas de tratamento que ainda são restritas a uma pequena parte da população. É considerada uma doença de início tardio na qual o fator masculino é responsável por metade dos casos (LOUIS et al., 2013). A infertilidade por fator masculino é um fenótipo complexo e ainda pouco conhecido. Metade dos pacientes investigados são categorizados como portadores de infertilidade idiopática, mesmo após a rotina diagnóstica incluindo avaliação clínica, exame físico e análise laboratorial (ESTEVES, 2016).

Os primeiros estudos sobre os fatores relacionados à infertilidade masculina não faziam seleção criteriosa de sua amostra. Qualquer homem com redução do potencial de fertilidade, independente do fator etiológico, era categorizado como infértil e passava a constituir o grupo amostral de alguns trabalhos. Com o passar do tempo, observamos que as causas genéticas têm sido especialmente detectadas em homens com fenótipo específico de alteração testicular, como por exemplo, a falência espermatogênica primária, resultando em oligozoospermia grave ou azoospermia não obstrutiva (STOUFFS et al., 2012).

Nos últimos anos, vários pesquisadores têm se dedicado à identificação de fatores genéticos que afetam a espermatogênese. A estratégia inicialmente utilizada baseava-se na investigação de genes com efeito potencial sobre a espermatogênese, descobertos a partir de modelos animais ou sugeridos pelos estudos de associação genômica (GWAS). Os resultados foram desapontadores, pois, muitas vezes, as mutações encontradas não eram confirmadas por outros grupos de pesquisa. Análises de famílias também não podiam ser realizadas, já que o próprio fenótipo não resultava na geração de descendência. Estudos em famílias com consanguinidade auxiliaram na identificação de genes que, em homozigose, resultavam em anormalidades seminais específicas como a globozoospermia (STOUFFS et al., 2012). A utilização de uma ferramenta de análise genômica, como a hibridação genômica comparativa, permite uma avaliação não direcionada de rearranjos cromossômicos submicroscópicos que podem associar-se com a infertilidade masculina (HALDER et al., 2016).

As variantes do número de cópia são consideradas fontes de diversidade genética com importante variação interindividual, mas também com papel na etiologia de doenças 
complexas como a deficiência intelectual, esquizofrenia, doenças cardiovasculares e câncer (TÜTTELMANN et al., 2011, LOPES et al., 2013, EGGERS et al., 2015). Apresentam distribuição variada no genoma, porém são mais frequentes em regiões próximas a duplicações segmentares. Além disso, modelos animais mostraram que CNVs são mais comumente observadas em regiões de genes com padrão de expressão tecido-específica do que em genes de expressão ubíqua (ZÖLLNER \& TESLOVICH, 2009). O potencial patogênico dessas alterações na infertilidade masculina foi correlacionado tanto com a distribuição como com a variação no número das $\mathrm{CNVs}$, resultando em alteração da recombinação gênica, falha meiótica e perda das células germinativas. (TÜTTELMANN et al., 2011; HALDER et al., 2016). Além disso, essas variantes podem levar à alteração da regulação gênica por diferentes mecanismos, como o efeito da dosagem de genes, o efeito de posição e o desmascaramento de mutações recessivas (deleções e LOHs) (HALDER et al., 2016). Diferentes CNVs, individuais ou compartilhadas, têm sido descritas em autossomos e em cromossomos sexuais e correlacionadas com o desenvolvimento de infertilidade (TÜTTELMANN et al., 2011, KRAUSZ et al., 2012, LOPES et al., 2013, EGGERS et al., 2015, NAKAMURA et al., 2017).

Dados da literatura sugerem que esse é o primeiro trabalho de investigação genômica, utilizando a técnica de hibridação comparativa, realizada em pacientes inférteis brasileiros com azoospermia não obstrutiva idiopática, selecionados de forma criteriosa. Acreditamos que a descrição e a caracterização dessas alterações genômicas possam contribuir para a compreensão de fatores genéticos relacionados à infertilidade masculina. Os principais fatores limitantes para a análise dessas alterações foram o tamanho do grupo controle e amostral, a resolução da plataforma de hibridação genômica e a escassez de bancos de dados específicos para análise da patogenicidade.

\subsection{Análise das variantes de número de cópias}

Uma questão recorrente no estudo de variantes de número de cópias em fenótipos complexos é se há diferença entre o número médio de CNVs ou quantidade de DNA (tamanho médio de ganhos/perdas) na comparação entre grupo amostral e controle. A literatura ainda é controversa no que diz respeito à investigação da infertilidade masculina. Tüttelmann e colaboradores, em 2011, estudaram um grupo de 126 pacientes com falência testicular primária (oligozoospermia grave e azoospermia não obstrutiva) e 100 controles 
férteis por técnica de hibridação genômica e não observaram diferenças estatísticas significativas quanto aos dois parâmetros descritos anteriormente. Dados semelhantes foram obtidos por Stouffs e colaboradores, em 2012, ao analisarem 8 pacientes com parada de maturação espermática e 20 controles férteis. Lopes e colaboradores, em 2013, obtiveram resultados semelhantes aos anteriores, porém ao avaliarem CNVs grandes $(>100 \mathrm{~kb})$ e raras (frequência menor que 5\%), observaram que a frequência e o tamanho médio de regiões alteradas foram maiores no grupo amostral. Nossos resultados não evidenciaram diferenças significativas referentes ao número total das CNVs, bem como quanto a quantidade de DNA alterado nos grupos analisados. Porém, observamos uma frequência maior de CNV do tipo perda com tamanho entre 100-499kb no grupo infértil. Zöllner e Teslovic, em 2009, já haviam relatado que o número de variantes detectadas, guarda relação direta com o tamanho da amostra e com a resolução da técnica de hibridação utilizada.

\subsubsection{Análise das CNVs do tipo ganho}

Descrevemos onze novos ganhos restritos ao grupo de pacientes com azoospermia não obstrutiva. Desses ganhos, 7 foram observados de forma individual e 4 de forma compartilhada. A análise dos ganhos individuais evidenciou que a maioria estava localizada no braço longo do cromossomo X (Xq12, Xq13.1, Xq21.1 e Xq24). Chianese e colaboradores, em 2014, descreveram 5 CNVs do tipo ganho, restritas ao cromossomo X, em pacientes com falência espermatogênica. Dessas 5 alterações, 2 foram privativas e 3 compartilhadas. Esses autores detectaram, inclusive, um ganho muito próximo ao descrito na sub-banda q21.1 do cromossomo X, porém, no caso deles, a duplicação tinha tamanho aproximado de $5,3 \mathrm{~kb}$ e não continha genes, enquanto que o ganho observado no presente trabalho foi de $1,2 \mathrm{~kb}$ e continha o gene $C O X 7 B$. Esse gene é responsável por codificar um membro da citocromo oxidase c, componente terminal da cadeia respiratória. Mutações associadas a esse gene foram descritas numa forma distinta de aplasia cútis congênita, associada com múltiplas lesões lineares de pele, envolvendo a face e o pescoço, assim como microcefalia, baixo ganho pôndero-estatural e dismorfias menores (OMIM 300887). Não foi encontrada relação desse gene com mecanismos patológicos associados à infertilidade masculina, porém Grzesiuk e colaboradores, em 2017, descreveram dois pacientes com oligozoospermia grave que apresentaram ganho nessa mesma sub-banda e envolvendo apenas o gene $C O X 7 B$. 
Os outros três ganhos individuais descritos no braço longo do cromossomo $\mathrm{X}$ correspondem ao ganho em Xq12 que incluía os genes UPRT e ZDHHC15. O gene UPRT codifica uma uracila-fosforibosiltransferase que participa do metabolismo nucleotídico, principalmente de pirimidinas, enquanto que o gene ZDHHC15 codifica uma enzima do grupo das palmitoiltransferases. Mutações nesse gene estão associadas a uma forma de deficiência intelectual ligada ao $\mathrm{X}$ não sindrômica. Nenhum mecanismo patogênico associado à infertilidade foi associado a esses dois genes (OMIM; GeneCards).

Na sub-banda q13.1, foi detectado um ganho de $894 \mathrm{~kb}$ compreendendo os genes $E F N B 1, F A M 155 B$ e $E D A$. O gene EFNB1 é um membro do grupo das efrinas, que são proteínas de membrana celular e ligantes de receptores tirosina quinase. Os mecanismos biológicos associados a esse gene envolvem repulsão, adesão e migração celular durante o desenvolvimento epitelial, vascular e neuronal. No sistema nervoso central, participa da formação das projeções longitudinais axonais. Há descrição de uma síndrome de genes contíguos compreendendo a deleção dos genes EFNB1 e PJA1, associada a graus variáveis de deficiência intelectual e de alterações faciais que incluem o espectro da displasia craniofrontonasal. O gene $F A M 155 B$ codifica uma proteína transmembrana de função desconhecida, enquanto que o gene EDA participa da sinalização celular do tecido ectodérmico. Mutações nesse gene estão associadas à displasia ectodérmica anidrótica (OMIM; GeneCards).

$\mathrm{Na}$ banda q24, foi observado ganho de $20 \mathrm{~kb}$, contendo os genes UPF3B, RNF113A e NDUFA1. O gene $U P F 3 B$ codifica uma proteína que participa de complexo multiproteico envolvido com controles pós-transcricionais. Mutações nesse gene estão associadas a duas formas de deficiência intelectual, uma não sindrômica e a outra, denominada de Síndrome de Lujan-Fryns. RNF113A é um gene intrônico associado com tricotiodistrofia, enquanto que NDUFA1 codifica proteína componente do complexo da cadeia respiratória. Mutações nesse gene estão associadas à encefalopatia mitocondrial de Leigh (OMIM; GeneCards). Nenhum processo patológico associados à infertilidade foi correlacionado com a função dos genes descritos acima, porém Nakamura e colaboradores, em 2017, descreveram um paciente com azoospermia não obstrutiva que apresentava um ganho de $181 \mathrm{~kb}$ na mesma região, porém a composição gênica era diferente, uma vez que o gene descrito nessa região foi $L O N R F 3$.

Foram ainda observados dois ganhos individuais que não estavam localizados em cromossomos sexuais. O ganho detectado em $7 \mathrm{q} 36.3$, de $3,8 \mathrm{~kb}$, contém o gene $S H H$ que 
codifica uma proteína essencial na determinação dos padrões corporais, tais como a determinação do padrão de eixos anterior e posterior e a formação do tubo neural e somitos ventrais. A descrição inicial desse gene foi em drosófila, porém seu papel na determinação dos padrões corporais é essencial em várias espécies, incluindo humanos. Alterações na proteína codificada por esse gene ou na sua via de sinalização estão relacionadas a malformações isoladas, como a holoprosencefalia e a polidactilia pré-axial, assim como padrões de malformações múltiplas, descritas na associação VACTER, além de tumorigênese, como o carcinoma basocelular, meduloblastoma, rabdomiossarcoma e glioma. Franco \& Yao, em 2012, estudaram o papel da via de sinalização hedgehog na diferenciação sexual de mamíferos e descreveram que essa via está associada à determinação do destino celular e à interação epitélio-mesênquima, que constitui um processo crítico no remodelamento e diferenciação tecidual, além da homeostase celular. Em camundongos, esses autores observaram que a desregulação dessa via pode comprometer desde a formação e manutenção dos túbulos seminíferos, bem como comprometer a espermatogênese, alterando a regulação do interstício (células de Leydig) sobre as células germinativas.

Na sub-banda q24.1 do cromossomo 16, foi observado um ganho contendo o gene GSE1 que codifica uma proteína componente do complexo histona deacetilase BRAF35HDAC (BHC). Esses complexos multiproteicos são repressores transcricionais, na medida em que participam da modificação da estrutura da cromatina. Atualmente, esse gene é considerado um oncogene importante em tumores neuroectodérmicos e de mama (OMIM; GeneCards). Apesar de não haver trabalhos que correlacionem alteração desse gene na fertilidade masculina, sabe-se que a regulação da transcrição gênica é fundamental para a espermatogênese (CUI et al., 2016).

Quatro ganhos raros foram compartilhados por homens com azoospermia não obstrutiva. Um ganho localizado na banda p13 do cromossomo 16 foi compartilhado por 2 indivíduos inférteis e continha os genes codificantes TSC2 e PKD1. A perda desses genes leva a uma síndrome de genes contíguos na qual o paciente apresenta, conjuntamente, esclerose tuberosa e doença renal policística. Não há descrição desses genes com infertilidade (OMIM; GeneCards).

O ganho detectado na sub-banda q21.33 do cromossomo 17 foi compartilhado por dois indivíduos com azoospermia obstrutiva. Grzesiuk e colaborabores, em 2017, também detectaram ganhos nessa mesma sub-banda em 2 pacientes com oligozoospermia moderada. 
Em ambos os trabalhos, a região de interseção incluía apenas o gene COL1A1. Esse gene codifica componentes das subunidades do colágeno tipo 1 e diferentes tipos de mutações levam a diferentes fenótipos clínicos como osteogênese imperfeita, síndrome de EhlersDanlos e doença de Caffey. Polimorfismos neste gene já foram associados à osteoporose. HE e colaboradores, em 2005, descreveram que a expressão de COL1Al ocorre exclusivamente nas espermatogônias de camundongos, já que, à medida em que essas células seguiam seu curso normal de diferenciação, perdiam a marcação para essa proteína. Chen e colaboradores, em 2012, avaliaram o papel desse gene na proliferação e diferenciação das células germinativas dos túbulos seminíferos de camundongos e observaram que a redução da expressão de COL1Al estimulava a diferenciação das espermatogônias.

O ganho detectado na sub-banda p13.3 do cromossomo 19 foi compartilhado por 2 indivíduos e apresentava os genes PLIN4, PLIN5, LRG1, SEMA6B, TNFAIP8L1. Os genes PLIN4 e PLIN5 regulam o balanço lipólise/lipogênese. O gene $L R G 1$ participa da transdução de sinal, adesão celular e regulação da diferenciação de granulócitos. SEMA6B é membro da família das semaforinas, participando da formação do axônio, enquanto que TNFAIP8L1 participa da biossíntese de fosfolipídios. Não há descrição de alteração desses genes relacionados com falência espermatogênica (OMIM; GeneCards).

Por fim, o ganho detectado na banda q28 do cromossomo $\mathrm{X}$ foi compartilhado por 3 pacientes inférteis e apresentava os genes AVPR2 (receptor de vasopressina), ARHGAP4 cuja deleção já foi descrita em diabetes nefrogênico, NAAlO que codifica uma enzima responsável pela acetilação no complexo de Golgi e RENBP que é uma proteína inibidora de renina. Além do conteúdo gênico, a banda Xq28 compõe a região pseudoautossômica número 2 (PAR 2) no cromossomo $\mathrm{X}$ que é essencial ao pareamento dos cromossomos sexuais durante a meiose. Halder e colaboradores, em 2016, descreveram que CNVs localizadas nas regiões pseudoatossômicas podem alterar a estrutura da sinapse, resultando em parada de maturação espermática com consequente infertilidade. Além disso, as regiões pseudoatossômicas contêm genes que escapam à inativação do X. Dessa forma, a superexpressão gênica pode resultar em efeito fenotípico. 


\subsubsection{Análise das CNVs do tipo perda}

Nesse estudo, foram descritas duas novas deleções raras e restritas ao grupo de pacientes com azoospermia não obstrutiva, sendo uma individual e a outra compartilhada. A deleção detectada em 3p21.2-21.31, de 227kb e contendo os genes CACNA2D2, C3orf18, HEMK1, CISH e MAPKAPK3 foi classificada como restrita e individual.

HEMK1 codifica uma proteína membro das metiltransferases de função ainda pouco conhecida, mas que tem expressão testicular. CISH codifica membro de reguladores negativos da sinalização de citocinas, enquanto que MAPKAPK3 codifica uma proteína quinase ativada por mitógenos que reprime a atividade do fator de transcrição E47. Esse último, regula a expressão gênica tecido-específica e a diferenciação celular. O gene CACNA2D2 codifica a subunidade $\alpha 2 \delta 2$ do canal de cálcio dependende de voltagem. Mutações nesse gene estão relacionadas com doenças genéticas neurológicas como a encefalopatia epiléptica de difícil controle, assim como cardiológicas, como síndrome de Brugada e síndrome do intervalo QT longo. Mais recentemente, observou-se que mutações ou alterações da regulação desse gene estão envolvidas com a cascata tumorigênica em diferentes tecidos, como pulmão, próstata, nasofaringe, mama e sistema nervoso central, na medida em que estimula a proliferação celular e angiogênese e inibe a apoptose (PRANDO et at., 2011; WARNIER et at.,2015). Apesar de não haver descrição específica desse gene afetando diretamente a espermatogênese, esse parece ser o gene candidato mais importante dessa região por dois motivos: primeiro, por participar de mecanismos patológicos que podem influir sobre a produção espermática (proliferação celular, apoptose e angiogênese) e segundo, por ser o único gene estrutural nessa CNV. Para CNVs do tipo deleção, proteínas estruturais são mais sensíveis à haploinsuficiência quando comparadas às proteínas com função catalítica (HAREL \& LUPSKI, 2017).

A perda compartilhada por dois indivíduos do grupo amostral foi detectada na subbanda q31.1 do cromossomo 2. Essa CNV também foi descrita por Grzesiuk e colaborabores, em 2017, em três pacientes com olizoospermia grave, porém o conteúdo gênico diferia nos dois estudos. No presente trabalho, a região envolvia a deleção do gene $D L X 1$, enquanto que o anterior reportou deleção envolvendo $D L X 2$. Esses genes apresentam funções similares, já que pertencem a uma mesma família de fatores de transcrição homeobox. Eles participam da regulação transcricional dos membros da superfamília $T G F \beta$. Seus produtos gênicos 
atuam no controle da morfogênese craniofacial, na diferenciação e sobrevivência de neurônios inibitórios do prosencéfalo e dos neurônios bipolares da retina. Clinicamente, as doenças associadas com esses genes incluem distúrbios neurocomportamentais, como transtorno de espectro autista, além de agenesia dentária familiar e síndromes malformativas de membros, incluindo mão em fenda. Em modelo animal, utilizando camundongos, foi observado que os genes da família $D L X$ regulam a migração e o desenvolvimento dos neurônios que secretam o hormônio regulador de gonadotrofinas (GnRH) (HOFFMANN et al., 2016). Dessa forma, a desregulação dessa via poderia causar hipogonadismo hipogonadotrófico comprometendo a fertilidade, mas não a falência espermatogênica primária.

A perda localizada em 15q11.2 está localizada numa região de CNV comum, segundo o DGV, porém essa alteração foi compartilhada por sete pacientes com azoospermia não obstrutiva, quase a metade do grupo amostral e não foi observada em nenhum indivíduo do grupo controle. A menor região de sobreposição entre essas sete CNVs inclui os genes OR4M2 e OR4N4 e o pseudogene $O R 4 N 3 P$, todos, pertencentes à família de receptores olfatórios. Famílias gênicas podem levar à instabilidade genômica e promover a formação de variantes de número de cópias por mecanismos de recombinação homóloga não alélica (HAREL \& LUPSKI, 2017).

Os receptores olfatórios (OR) foram descritos por Linda Buck e Richard Axel, em 1991, através de uma série de experimentos fisiológicos e bioquímicos que indicaram que os neurônios sensitivos olfatórios são regulados por receptores acoplados à proteína G. Esses receptores participam de respostas celulares a hormônios e neurotransmissores e são formados por proteínas integrais com sete domínios transmembrana, uma extremidade aminoterminal no exterior da célula e outra carboxiterminal no intracelular.

Os receptores olfatórios compreendem uma das maiores famílias gênicas dispersas no genoma humano e a maior família de quimiorreceptores, com cerca de 370 genes descritos. São classificados em duas classes distintas, de acordo com a sua distribuição filogenética e com a sequência de aminoácidos da extremidade aminoterminal. A classe I foi descrita inicialmente em animais aquáticos (peixes e anfíbios) e sua função seria a detecção de odorantes solúveis em água. Em humanos, os genes da classe I estão organizados no cromossomo 11. A classe II de receptores olfatórios é encontrada apenas em animais 
terrestres e correspondem a 80-90\% desses receptores em humanos. Apresentam distribuição global no genoma, com exceção dos cromossomos 22 e Y (NIIMURA, 2012).

Um ano após a descrição dos receptores olfatórios, Parmentier e colaboradores, em 1992, demonstraram a expressão desse tipo de receptor fora do epitélio olfatório, mais precisamente, nas células germinativas masculinas de mamíferos, cuja função estaria associada com a quimiotaxia durante a fecundação. Essa expressão foi denominada de ectópica.

Atualmente, a expressão desses receptores é descrita em diferentes tecidos e órgãos como: língua, próstata, elementos figurados do sangue, músculo esquelético e cardíaco, pele, pulmão, placenta, embrião, rins, fígado, cérebro, intestino e testículo. Nesses tecidos, há expressão conjunta de diferentes receptores olfatórios, enquanto que no epitélio olfatório, cada neurônio expressa especificamente um tipo de receptor. Esses receptores apresentam diferentes funções em diferentes tecidos, como a comunicação e reconhecimento célulacélula, importante na embriogênese e na quimiossensação cutânea; regeneração e reparo tecidual dos cardiomiócitos e do músculo esquelético; progressão, crescimento e até mesmo, metástase de determinados tipos de tumores, como o neuroendócrino e próstata; sensores nutricionais, ativando a liberação de serotonina pelas células enterocromafins e ainda, participam da regulação do ciclo celular, ativando proteínas necessárias para o controle de etapas específicas, como a citocinese (FLEGEL et al., 2016).

Mais de 80 receptores olfatórios foram descritos no testículo e nas células germinativas, sendo que alguns têm expressão restrita a esse tecido. A quimiotaxia de espermatozoides é considerada uma de suas principais funções. Neste caso, um determinado quimioatraente liga-se ao receptor, que ativará uma proteína canal da família CatSper que, por sua vez, permitirá um influxo de íons cálcio, resultando no aumento dos batimentos do flagelo. Além da função de quimiotaxia, os $\mathrm{OR}$ desempenham o controle da espermatogênese, regulando a expressão de proteínas no ciclo celular (FLEGEL et al, 2016).

\subsubsection{Análise das CNVs do tipo ganho localizadas no cromossomo Y}

Não foram descritas deleções no cromossomo $\mathrm{Y}$ em nenhum dos indivíduos analisados, reforçando o entendimento de que a PCR multiplex é ainda um método robusto na investigação de microdeleções no braço longo do cromossomo Y. Mesmo assim, essa 
técnica apresenta limitações, como: a baixa sensibilidade na detecção assim como, inconsistência na eficiência/inibição da amplificação dos primers, além de ser considerada uma técnica laboriosa. Clinicamente, suas limitações estão relacionadas à complexidade de investigação das deleções parciais da região de AZFc (ZHEG et al., 2014).

Há cerca de 10 anos, diferentes trabalhos têm associado as duplicações na região de AZFc como fator de risco para falha espermatogênica (LIN et al., 2007; LOPES et al., 2013). A região de AZFc é composta por 8 famílias de genes de cópia múltipla, incluindo DAZ, BPY2, CDY1, GOLGA2LY, CSPG4LY, TTTY3, TTTY4 e TTTY17, organizadas na forma de grandes unidades repetidas, denominadas de amplicons. Esse padrão predispõe a uma série de alterações genômicas, tais como: deleções, duplicações e rearranjos deleçãoduplicação, mediados pela recombinação homóloga não alélica. A deleção completa de $\mathrm{AZFc}(\mathrm{b} 2 / \mathrm{b} 4)$ remove as 8 famílias de genes de cópia múltipla dessa região e é reconhecida como um fator de falha espermatogênica em diferentes populações ou grupos étnicos, porém deleções parciais e duplicações nessa região têm demonstrado resultados controversos nas diferentes populações estudadas. Duplicações envolvendo DAZ1/DAZ2 foram consideradas cruciais para a espermatogênese normal de europeus, enquanto que alterações em $D A Z 3 / D A Z 4$ foram associadas à falha espermatogênica na população chinesa (LU et al., 2014).

Atualmente, considera-se que o efeito de um determinado rearranjo envolvendo a região de $\mathrm{AZFc}$ com a falha espermatogênica, parece ser modulado por fatores populacionais específicos como, por exemplo, o tipo de haplogrupo específico do cromossomo Y (YANG et al., 2015).

No presente trabalho, observamos que os ganhos envolvendo a região de $\mathrm{AZFc}$, com tamanho variando de 11-16kb e contendo cópias dos genes DAZ1/DAZ4 foram observadas tanto no grupo controle, como no grupo amostral, favorecendo a ideia de que essas alterações não parecem ter relação com o fenótipo de azoospermia obstrutiva. Porém, nessa mesma sub-banda, foram descritos 2 ganhos grandes, com mais de $1 \mathrm{Mb}$ de tamanho, em 2 indivíduos do grupo amostral. Além da diferença de tamanho, que pode favorecer mecanismos de recombinação homóloga não alélica, ocorre diferença de conteúdo gênico que, por sua vez, pode resultar em alteração da espermatogênese através da mudança do número de cópias dos genes presentes nesta região.

CDY abrange uma família de genes de cópias múltiplas, com quatro diferentes componentes $C D Y 1, C D Y 1 B, C D Y 2 A$ e $C D Y 2 B$, localizados na região de sobreposição entre 
$\mathrm{AZFb}$ e AZFc (AZFbc). Essa família gênica codifica proteínas que se expressam especificamente em espermátides maduras, colaborando com a etapa de protaminação (LAHN et al., 2002). Um paciente do grupo amostral evidenciou um ganho de $10 \mathrm{~kb}$ envolvendo os genes $C D Y 2 A$ e $C D Y 2 B$ que não foi encontrado no grupo controle, mas que o DGV descreveu como uma variante comum. Dificilmente, uma variante tão pequena e comprometendo a dosagem de genes que regulam uma etapa final da espermatogênese poderia resultar em azoospermia.

O ganho de 106kb na sub-banda p11.2 do cromossomo Y, descrita em um paciente do grupo amostral, foi reportada por TÜTTELMANN e colaboradores, em 2011, em um paciente com falha espermatogênica. A diferença entre esses dois ganhos envolvia a posição genômica e o conteúdo gênico. No trabalho de TÜTTELMANN e colaboradores não havia descrição de gene, enquanto que no presente trabalho, a região compreendia um gene codificante de RNA longo (LINC00279).

LINC00279 tem expressão exclusiva testicular e sua função ainda é pouco conhecida. Assim como os pequenos miRNAs, que tem expressão espacial e temporal, os RNAs longos são ativados de forma ordenada, dependendo do tipo de célula e do estágio de divisão celular. Esse padrão de expressão parece regular diversas etapas da divisão meiótica e espermiogênese. Diferentemente da regulação proteica, na qual genes codificantes de proteína são silenciados durante a fase de paquíteno por um processo denominado de inativação meiótica dos cromossomos sexuais (MSCI, do inglês, meiotic sex chromosome inactivation), a expressão de RNAs longos é maior nesta fase específica da divisão celular (WICHMAN et al., 2017). Essa CNV em Yp11.2 corresponde a mais um ganho raro sem descrição anterior no DGV.

\subsection{Análise das regiões de perda de heterozigosidade}

O entendimento da patogenicidade associada com as regiões de perda de heterozigose é ainda um assunto desafiador. Vários estudos, em diferentes tipos de neoplasia, têm reconhecido o papel das LOHs na instabilidade genômica das células tumorais, porém ainda são escassos os trabalhos avaliando o significado dessas alterações em fenótipos complexos, como infertilidade masculina (JOHNSON et al., 2016). A ausência de bancos de dados públicos que auxiliam na avaliação da patogenicidade corresponde a mais uma limitação na investigação dessas alterações genômicas. 
O presente trabalho evidenciou que não foram observadas diferenças significativas entre o número e o tamanho das LOHs pela média de indivíduos em ambos os grupos analisados. Três regiões de perda de heterozigosidade foram associadas à possível ação negativa sobre fertilidade masculina, já que foram compartilhadas por pelo menos dois indivíduos do grupo amostral e continham genes com potencial de alterar mecanismos fisiológicos associados com a espermatogênese.

A LOH descrita em 1p31.1 foi compartilhada por 5 indivíduos do grupo amostral e continha os genes $L R R C 7$ e $L R R C 40$, membros de uma família de proteínas de repetições ricas em leucina (LRR). Esse domínio proteico está presente em diversas famílias de proteínas com múltiplas funções, na medida em que sua estrutura é capaz de estabelecer diferentes interações. LRRC7, também denominada de densina-180 é um dos principais componentes da densidade pós-sináptica de neurônios excitatórios. Modelo animal com perda bialélica desse gene apresentou uma variedade de fenótipos neurocomportamentais que se assemelhavam ao transtorno do espectro autista e à esquizofrenia. Variantes nesse gene foram associadas com susceptibilidade ao transtorno bipolar em humanos (FIORENTINO et al., 2017; WANG et al., 2017).

As densinas são proteínas pertencentes à família das sialoglicoproteínas que têm expressão não só nas densidades pós-sinápticas do sistema nervoso central, mas também nos podócitos, controlando a filtração renal e no testículo, mais precisamente, na membrana das células de Sertoli, participando da formação das junções aderentes entre as células de Sertoli e as células germinativas. A interação célula-célula entre as células de Sertoli e as células germinativas é crucial para a adesão e a morfogênese do túbulo seminífero, contribuindo para a formação da barreira hematotesticular. Interferência na formação dessas junções afetam a migração das células germinativas, podendo comprometer a espermatogênese (LASSILA et al., 2007). Ainda não há um papel definido para o gene LRRC40, mas, devido à similaridade estrutural, acredita-se que também participe da formação de estruturas juncionais.

Em 7q21.1, foi descrita uma LOH compartilhada por 2 indivíduos do grupo amostral que continha dois membros do grupo das semaforinas. As semaforinas são proteínas que compartilham um domínio de 500 aminoácidos denominado de Sema e que estão organizadas em 7 diferentes classes. As classes 1 e 2, descritas apenas em invertebrados, a classe 3 , composta por proteínas secretadas e as classes de 4 a 7 , por proteínas ligadas à 
membrana em vertebrados. Essas proteínas foram descritas, inicialmente, na formação dos cones dos axônios neuronais. Além desse papel, regulam a migração das células endoteliais vasculares, o desenvolvimento cardiovascular, a ativação linfocitária com a regulação da resposta imune e a morfogênese óssea, renal, pulmonar e da retina. Além da regulação de processos fisiológicos, as semaforinas já foram correlacionadas com processos patológicos como doenças autoimunes (esclerose múltipla e doenças desmielinizantes do sistema nervoso central) e câncer, na medida em que regulam angiogênese, o microambiente tumoral e metástase (VALDEMBRI et al., 2016; NISHIDE \& KUMANOGOH, 2018).

As semaforinas da classe 3 são formadas por 7 diferentes moléculas solúveis, de aproximadamente $100 \mathrm{kd}$, secretadas por diferentes tipos celulares, tais como células epiteliais, endoteliais, neuronais e tumorais. Sua função é regulada pela ligação ao receptor plexina e diferentes moléculas de adesão e adaptores, como as neuropilinas, podem auxiliar na ligação a seu receptor. O papel mais conhecido dessas proteínas é a regulação imune. O gene $S E M A 3 A$ promove a migração de células dendrítica para os linfonodos, enquanto que SEMA3E regula o tráfego de timócitos durante a diferenciação (REIDY \& TUFRO, 2011; NISHIDE \& KUMANOGOH, 2018).

Poucos trabalhos têm relacionado o papel das semaforinas na fertilidade humana. $\mathrm{O}$ trabalho de Giacobini, em 2015, evidenciou que as semaforinas da classe 3 são essenciais para a migração, sobrevivência e plasticidade estrutural e funcional dos neurônios liberadores de gonadotrofinas. Esses neurônios são formados fora do sistema nervoso central, numa estrutura denominada de placódio nasal e precisam migrar para a aérea préóptica do hipotálamo, seguindo os nervos olfatório e vomeronasal. Esses neurônios são integrados a uma rede de neurônios e células da glia responsáveis pela secreção regulada de hormônio liberador de gonadotrofinas $(\mathrm{GnRH})$ na circulação portal hipofisária. Dessa forma, esse hormônio regula os gonadotrofos da hipófise anterior que irão produzir e liberar LH e FSH. A desregulação do neuroeixo causa hipogonadismo hipogonadotrófico, resultando em infertilidade de origem pré-testicular, porém como essas proteínas têm como função básica a regulação da migração celular durante a organogênese, podemos considerar que polimorfismos ou outras variantes genéticas possam comprometer não só a migração das células germinativas, mas também desregular mecanismos fisiológicos, como a angiogênese no tecido testicular. 
Na sub-banda q21.1-21.2 do cromossomo 12 foi detectada uma LOH compartilhada por 2 indivíduos inférteis e que continha genes da superfamília $C A P$. Essa superfamília de proteínas, também denominada de proteínas de revestimento espermático, é constituída por 8 diferentes subfamílias. Um dessas subfamílias é denominada de proteína associada a patogênese do glioma do tipo 1 (GLIPR1- do inglês, glioma pathogenesis-related 1) que por sua vez é formada por 3 diferentes genes codificantes de proteínas GLIPR1, GLIPR1- like 1 (GLIPR1L1) e GLIPR1-like 2 (GLIPR1L2). Em humanos, GLIPR1 e GLIPR1L2 são expressos em diversos tecidos, enquanto que GLIPRIL1 tem expressão predominantemente testicular. GLIPRl é considerado como um supressor tumoral, enquanto que GLIPRIL1 e GLIPR1L2 não tem função ainda reconhecida. Alguns trabalhos utilizando modelo animal apontam padrão variado de expressão de GLIPRIL1 durante a maturação das células germinativas, mais precisamente durante a fase de capacitação da espermiogênese. Além disso, é creditado a GLIPRIL1 papel no complexo formado durante o encontro do espermatozoide com o ovócito (GIBBS et al., 2008). Apesar de elevada expressão dessas proteínas no tecido testicular, não há dados na literatura que impliquem diretamente esses genes com falha espermatogênica.

No geral, não foram detectadas variantes genéticas individuais de alto impacto, mas sim alterações genômicas ora individuais, ora compartilhadas que podem estar associadas com o fenótipo azoospermia não obstrutiva. Dessa forma, esse trabalho reforça o entendimento de que a infertilidade masculina por falência espermatogênica primária deve ser analisada no contexto de um fenótipo complexo no qual algumas variantes/alterações genéticas podem alterar mecanismos moleculares/celulares, ainda pouco estudados, que comprometem a espermatogênese. 


\section{CONCLUSÕES}

O tão sonhado ponto final... 


\section{CONCLUSÕES}

8.1. Detectamos diferenças, tanto no número como no tamanho das variantes genômicas (CNVs e LOHs), entre o grupo controle e o grupo formado por homens com azoospermia não obstrutiva, porém essas diferenças não foram estatisticamente significativas.

8.2. Onze novos ganhos restritos ao grupo de pacientes com azoospermia não obstrutiva foram descritos nesta amostra. Desse grupo, os ganhos em 7q36.3, 17q21.33 e Xq21.1 foram considerados significativos.

8.3. Duas novas deleções restritas ao grupo de pacientes inférteis foram detectadas em 2q31.1 e 3p21.1-21.31 e consideradas potencialmente associadas à falência espermatogênica primária.

8.4. Foi detectado um ganho no braço curto do cromossomo Y (Yp11.2), não descrito no DGV, que foi considerado potencialmente relevante para o fenótipo de infertilidade masculina.

8.5. Ganhos envolvendo a sub-banda Yq11.223 e contendo cópias dos genes DAZ1 e DAZ4 foram detectados em pacientes inférteis e no grupo controle, sendo considerados benignos.

8.6. Três regiões de perda de heterozigosidade, localizadas em 1p31.1, 7q21.1 e 12q21.121.2, foram compartilhadas por pacientes com azoospermia não obstrutiva e continham genes associados à espermatogênese. 


\section{REFER $\hat{E} \mathcal{N} C I \mathcal{A S}$}

Isso que fazemos é uma paráfrase. Contamos a algúem o que já foi dito por outra pessoa com outras palavras

Prof. José Antônio Ferreira da Silva 


\section{REFERÊNCIAS BIBLIOGRÁFICAS}

AGARWAL, A.; MULGUND, A.; HAMADA, A.; CHYATTE, M. R. A unique view on male infertility around the globe. Reproductive Biology and Endocrinology, v. 37, n. 13, p. 1-9, 2015.

ALKAN, C.; COE, B. P.; EICHLER, E. E. Genome structural variation discovery and genotyping. Nature Reviews Genetics, v. 12, n. 5, p. 363-376, 2011. doi:10.1038/nrg2958

AMATO, L. G. L.; LATRONICO, A. C.; SILVEIRA, L. F. G. Molecular and genetic aspects of congenital isolated hypogonadotropic hypogonadism. Endocrinology \& Metabolism Clinics, v. 46, n. 2, p. 283-303, 2017. doi: 10.1016/j.ecl.2017.01.010

AMERICAN SOCIETY FOR REPRODUCTIVE MEDICINE (ASRM). Practice Committee of the American Society for Reproductive Medicine. Diagnostic evaluation of the infertile male: a committee opinion. Fertility and Sterility, Alabama, v. 103, n. 3, p. e18-e25, 2015. doi: 10.1016/j.fertnstert.2014.12.103

ANAWALT, B. D. Approach to male infertility and induction of spermatogenesis. Journal of Clinical Endocrinology and Metabolism, v. 98, n. 9, p. 3532-3542, 2013. doi:10.1210/jc.2012-2400

ARAFAT, M.; HAR-VARDI, I.; HARLEV, A.; LEVITAS, E.; ZEADNA, A.; ABOFOULAZAB, M.; DYOMIN, V.; SHEFFIELD, V. C.; LUNENFELD, E.; HULEIHEL, M.; PARVARI, R. Mutation in TDRD9 causes non-obstructive azoospermia in infertile men. Journal of Medical Genetics, v. 54, n. 9, p. 633-639, 2017. doi:10.1136/jmedgenet-2017104514

ASERO, P.; CALOGERO, A. E.; CONDORELlI R. A.; MONGIOI L.; VICARI E.; LANZAFAME, F.; CRISCI, R.; LA VIGNERA, S.; Relevance of genetic investigation in male infertility. Journal of Endocrinological Investigation, v. 37, n. 5, p. 415-427, 2014. doi:10.1007/s40618-014-0053-1

ASTON, K. I. Genetic susceptibility to male infertility: news from genome-wide association studies. Andrology, v. 2, n. 3, p. 315-321, 2014. doi:10.1111/j.2047-2927.2014. 00188.x

BAKER, M. Structural variation: the genome's hidden architecture. Nature Methods, v. 9, n. 2, p. 133-137, 2012.

BASHAMBOO, A.; FERRAZ-DE-SOUZA, B.; LOURENÇO, D.; LIN, L.; SEBIRE, N. J.; MONTJEAN, D.; BIGNON-TOPALOVIC, J.; MANDELBAUM, J.; SIFFROI, J-P.; CHRISTIN-MAITRE, S.; RADHAKRISHNA, U.; ROUBA, H.; RAVEL, C.; SEELER, J.; ACHERMANN, J. C.; McELREAVEY, K. Human male infertility associated with mutations in NR5Al encoding steroidogenic factor 1. American Journal of Human Genetics, v. 87, n. 4, p. 505-512, 2010. doi: 10.1016/j.ajhg.2010.09.009

BEHRE H. M.; BERGMANN, M.; SIMONI, M.; TÜTTELMANN, F. Primary testicular failure. In: DE GROOT, L. J.; CHROUSUS, G.; DUNGAN K, et al. (Ed); Endotext, South Dartmouth, 2015. www.endotext.org 
BEROOKHIM, B. M.; PALERMO, G. D.; ZANINOVIC, N.; ROSENWAKS, Z.; SCHLEGEL, P. M. Microdissection testicular sperm extraction in men with Sertoli cellonly testicular histology. Fertility and Sterility, v. 102, n. 5, p. 1282-1286, 2014. doi:10.1016/j.fertnstert.2014.08.007

BHASIN, S.; JAMESON, J. L.; Disorders of the testes and male reproductive system. In: LONGO, D. L.; FAUCI, A.S.; KASPER, D. L.; HAUSER, S. L.; JAMESON, J. L.; LOSCALZO, J. (Ed); Harrison's Principles of Internal Medicine, $19^{\circ} \mathrm{ed}, 2015$.

BICHILE, D.L.; KHARKAR, A. R.; MENON, P.; POTNIS-LELE, M.; BANKAR, M.; SHROFF, G.A. Y chromosome: structure and biological functions. Indian Journal of Basic and Applied Medical Research, v. 3, n. 3, p. 152-160, 2014.

BIENIEK, J. M.; LO, K. C.; Recent advances in understanding \& managing male infertility. F1000Research, v. 5, p. 1-7, 2016. doi:10.12688/f1000research.9375.1

BIGNELL, G. R.; HUANG, J.; GRESHOCK, J.; BUTLER, A.; WEST, S.; GRIGOROVA, M.; JONES, K. W.; WEI, W.; STRATTON, M. R.; FUTREAL P. A.; WEBER, B.; SHAPERO, M. H.; WOOSTER, R. High-resolution analysis of DNA copy number using oligonucleotide microarrays. Genome Research, v.14, n. 2, p. 287-295, 2004. doi:10.1101/gr.2012304

BISHT, S.; FAIQ, M.; TOLAHUNASE, M.; DADA, R.; Oxidative stress and male infertility. Nature Reviews Urology, v. 14, n. 8, p. 470-485. 2017. doi:10.1038/nrurol.2017.69

BOGGULA, V. R.; AGARWAL, M.; KUMAR, R.; AWASTHI, S.; PHADKE, S. R. Recurrent benign copy number variants \& issues in interpretation of variants of unknown significance identified by cytogenetic microarray in Indian patients with intellectual disability. Indian Journal of Medical Research, v. 142, n. 6, p. 699-712, 2015. doi: 10.4103/0971-5916.174561

BONOMI, M.; ROCHIRA, V.; PASQUALI, D.; BALERCIA, G.; JANNINI, E. A.; FERLIN, A. Klinefelter syndrome (KS): genetics, clinical phenotype and hypogonadism. Journal of Endocrinological Investigation, v. 40, p. 123-134, 2017. doi:10.1007/s40618016-0541-6

BOROUJENI, P. B.; SABBAGHIAN, M.; DIZAJI, A. V.; MORADI, S. Z.; ALMADANI, N.; LASHKARI, F. M.; ZAMANIAN, M. R.; MEYBODI, A. M. Clinical aspects of infertile 47,XYY patients: a retrospective study. Human Fertility, p. 1-6, 2017. doi:10.1080/14647273.2017.1353143

BRAGA, L. H.; LORENZO, A. J. Cryptorchidism: A practical review for all community healthcare providers. Canadian Urological Association Journal, v. 1, n. 2, p. S26-S32, 2017. Supplement 1. doi:10.5489/cuaj.4343

CARRELL, D. T.; ASTON, K. I.; OLIVA, R.; EMERY, B. R.; DE JONGE, C. J. The "omics" of human male infertility: integrating big data in a systems biology approach. Cell and Tissue Research, v. 363, n. 1, p. 295 - 312, 2016. doi:10.1007/s00441-015-2320-7 
CENTOLA, G. M. Semen assessment. Urologic Clinics of North America, v. 41, p. 163167, 2014. doi:10.1016/j.ucl.2013.08.007

CHEN, S-H.; LI, D; XU, C.; Downregulation of Collal induces differentiation in mouse

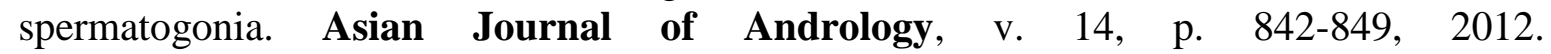
doi:10.1038/aja.2012.66

CHEN, X.; LI, X.; GUO, J.; ZHANG, P.; ZENG, W. The roles of microRNAs in regulation of mammalian spermatogenesis. Journal of Animal Science and Biotechnology, v. 8, n. 35, p. 1-8, 2017. doi:10.1186/s40104-017-0166-4

CHIANESE, C.; GUNNING, A. C.; GIACHINI, C.; DAGUIN, F.; BALERCIA, G.; ARS, E.; LO GIACCO, D.; RUIZ-CASTAN, E.; FORTI, G.; KRAUSZ, C. X chromosome-linked CNVs in male infertility: discovery of overall duplication load and recurrent, patient specific gains with potential clinical relevance. Plos One, v. 9, n. 6, e97746, 2014. doi:10.1371/journal.pone.0097746

COCUZZA, M.; ALVARENGA, C.; PAGANI, R. The epidemiology and etiology of azoospermia, Clinics, v. 68, p. 15-26, 2013. Suplemento 1. doi:10.6061/clinics/2013(Sup01)03

COLAIANNI, V.; MAZZEI, R.; CAVALLARO, S. Copy number variations and stroke. Neurological Sciences, v. 37, n. 12, p. 1895-1904, 2016. doi:10.1007/s10072-016-2658-y

COOPER, T. G.; NOONAN, E.; VON ECKARDSTEIN, S.; AUGER, J.; BAKER, H. W. B.; BEHRE, H. M.; HAUGEN, T. B.; KRUGER, T.; WANG, C.; MBIZVO, M. T.; VOGELSONG, K. M. World Health Organization reference values for human semen characteristics. Human Reproduction Update, v.16, n. 3, p. 231-245, 2010. doi:10.1093/humupd/dmp048

COUTTON, C.; SATRE, V.; ARNOULT, C.; RAY, P. Génétique de l'infertilité masculine: les nouveaux acteurs. Médecine/Sciences, v. 28, n. 5, p. 497-502, 2012. doi:10.1051/medsci/2012285014

CUI, X.; JING, X.; WU, X.; YAN, M.; LI, Q.; SHEN, Y.; WANG, Z. DNA methylation in spermatogenesis and male infertility. Experimental and Therapeutic Medicine, v. 12, p. 1973-1979, 2016. doi:10.3892/etm.2016.3569

DAM, A. H.; KOSCINSKI, I.; KREMER, J. A.; MOUTOU, C.; JAEGER, A. S.; OUDAKKER, A. R.; TOURNEYE, H.; CHARLET, N.; LAGIER-TOURENNE, C.; VAN BOKHOVEN, H.; VIVILLE, S. Homozygous mutation in SPATA 16 is associated with male infertility in human globozoospermia. American Journal of Human Genetics, v. 81, n. 4, p. $813-820$, 2007. doi: $10.1086 / 521314$

D’AMOURS, G.; LANGLOIS, M.; MATHONNET, G.; FETNI, R.; NIZARD, S.; SROUR, M.; TIHY, F.; PHILLIPS, M. S.; MICHAUD, J. L.; LEMYRE, E. SNP arrays: comparing diagnostic yields for four platforms in children with developmental delay. BMC Medical Genomics, v. 7, n. 70, p. 2-17, 2014. doi:10.1186/s12920-014-0070-0 
D'AURORA, M.; FERLIN, A.; DI NICOLA, M.; GAROLLA, A.; DE TONI, L.; FRANCHI, S.; PALKA, G.; FORESTA, C.; STUPPIA, L.; GATTA, V. Deregulation of Sertoli and Leydig cells function in patients with Klinefelter syndrome as evidenced by testis transcriptome analysis. BMC Genomics, v. 16, n. 156, 2015. doi:10.1186/s12864-015$1356-0$

DE BRAEKELEER, M.; DAO, T. N. Cytogenetic studies in male infertility: a review. Human Reproduction, v. 6, p. 245-250, 1991.

DENG, Y.; ZHANG, W.; SU, D.; YANG, Y.; MA, Y.; ZHANG, H.; ZHANG, S. Some single nucleotide polymorphisms of MSY2 gene might contribute to susceptibility of spermatogenic impairment in idiopathic infertile men. Urology, v. 71, n. 5, p. 878-882, 2008. doi:10.1016/j.urology.2007.12.055

DIETERICH, K.; SOTO-RIFO, S.R.; FAURE, A. K.; HENNEBICQ, S.; BEN-AMAR, B.; ZAHI, M.; PERRIN, J.; MARTINEZ, D.; SÈLE, B.; JOUK, P. S.; AHLMANN, T.; ROUSSEAUX, S.; LUNARDI, J.; RAY, P. F. Homozygous mutation of AURKC yields large-headed polyploidy spermatozoa and causes male infertility. Nature Genetics, v. 39, n. 5, p. 661-665, 2007. doi:10.1038/ng2027

DONG, Y.; PAN, Y.; WANG, R.; ZHANG, Z.; XI, Q.; LIU, R-Z. Copy number variations in spermatogenic failure patients with chromosomal abnormalities and unexplained azoospermia. Genetics and Molecular Research, v. 4, n. 14, p. 16041-16049. 2015. doi: $10.4238 / 2015$

EGGERS, S.; DeBOER, K. D.; VAN DEN BERGEN, J.; GORDON, L.; WHITE, S. J.; JAMSAI, D.; McLACHLAN, R.; SINCLAIR, A. H.; O'BRAYAN, M. K. Copy number variation associated with meiotic arrest in idiopathic male infertility. Fertility and Sterility, v. 103, n. 1, p. 214-219. 2015. doi:10.1016/j.fertnstert.2014.09.030

ESTEVES, S. Novel concepts in male factor infertility: clinical and laboratory perspectives. Journal of Assisted Reproduction and Genetics, v. 33, n. 10, p. 1319-1335, 2016. doi:10.1007/s10815-016-0763-8

ESTEVES, S. C.; ZINI, A.; AZIZ, N.; ALVAREZ, J. G.; SABANEGH Jr, E. S.; AGARWAL, A. Critical appraisal of World Health Organization's new reference values for human semen characteristics and effect on diagnosis and treatment of subfertile men. Urology, v. 79, n. 1, p. 16-22, 2012. doi:10.1016/j.urology.2011.08.003

FERLIN A.; RAICU F.; GATTA V.; ZUCARELLO D.; PALKA G; FORESTA C.; Male infertility: roles of genetic background. Reproductive BioMedicine Online, v. 14, n. 6, p. 734-745, 2007. doi:10.1016/S1472-6483(10)60677-3

FEUK, L.; CARSON, A. R.; SCHERER, S. W. Structural variation in the human genome. Nature Reviews Genetics, v. 7, n. 2, p. 85-97, 2006. doi:10.1038/nrg1767

FIORENTINO, A.; SHARP, S. I.; KANDASWAMY, R.; GURLING, H. M. D.; BASS, N. J.; McQUILLIN, A. Genetic variant analysis of the putative regulatory regions of the LRRC7 gene in bipolar disorder. Psychiatric Genetics, v. 26, n. 2, p. 99-10, 2016. doi:10.1097/YPG.0000000000000119. 
FIRTH, H. V.; HURST, J. A.; HALL, J. G. Oxford Desk Reference: Clinical Genetics. Oxford Universe Press, 2005.

FLANNIGAN, R.; SCHLEGEL, P. N. Genetic diagnostic of male infertility in clinical practice. Best Practice \& Research Clinical Obstetrics \& Gynaecology. 2017. IN PRESS. doi:10.1016/j.bpobgyn.2017.05.002

FLEGEL, C.; VOGEL, F.; HOFREUTER, A.; SCHREINER, B. S. P.; OSTHOLD, S.; VEITINGER, S.; BECKER, C.; BROCKMEYER, N. H.; MUSCHOL, M.; WENNEMUTH, G.; ALTMÜLLER, J.; HATT, H.; GISSELMANN, G. Characterization of the Olfactory Receptors Expressed in Human Spermatozoa. Frontiers in Molecular Bioscience, v. 2, n. 73, 2016. doi: 10.3389/fmolb.2015.00073

FRANCO, H. L.; YAO, H. H-C.; Sex and hedgehog: roles of genes in the hedgehog signaling pathway in mammalian sexual differentiation. Chromosome Research, v. 20, n. 1, p. 247258, 2012. doi: 10.1007/s10577-011-9254-z

FRÜHMESSER, A.; VOGT, P. H.; ZIMMER, J.; WITSCH-BAUMGARTNER, M.; FAUTH, C.; ZSCHOCKE, J.; PINGERRA, G-M.; KOTZOT, D.; Single nucleotide polymorphism array analysis in men with idiopathic azoospermia or oligoasthenozoospermia syndrome. Fertility and Sterility, v.100, n. 1, p. 81-87, 2013. doi:10.1016/j.fertnstert.2013.03.016

GAJBHIYE, R.; KADAM, K.; KHOLE, A.; GAIKWAD, A.; KADAM, S.; SHAH, R.; KUMARASWAMY, R.; KHOLE, V. Cystic fibrosis transmembrane conductance regulator (CFTR) gene abnormalities in Indian males with congenital bilateral absence of vas deferens \& renal anomalies. Indian Journal of Medical Research, v. 143, n. 5, p. 616-623, 2016. doi:10.4103/0971-5916.187110

GALAN, J. J.; DE FELICI, M.; BUCH, B.; RIVERO, M. C.; SEGURA, A.; ROYO, J. L.; CRUZ, N.; REAL, L. M.; RUIZ, A. Association of genetic markers within the KIT and KITLG genes with human male infertility. Human Reproduction, v. 21, n. 12, p. 31853192, 2006. doi:10.1093/humrep/del313

GALAN, J. J.; BUCH, B.; CRUZ, N.; SEGURA, A.; MARON, F. J.; BASSAS, L.; MARTINEZ-PINEIRO, L.; REAL, L. M.; RUIZ, A. Multilocus analyses of estrogen-related genes reveal involvement of the ESRl in male infertility and the polygenic nature of pathology. Fertility and Sterility, v. 84, n.4, p. 910-918, 2005. doi: 10.1016/j.fertnstert.2005.03.070

GIACOBINI, P. Shaping the reproductive system: role of semaphorins in GnRH development and function. Neuroendocrinology, v. 102, n.3, p. 200-215, 2015. doi:10.1159/000431021

GIBBS, G. M.; ROELANTS, K.; O’BRYAN, M. K. The CAP Superfamily: Cysteine-Rich Secretory Proteins, Antigen 5, and Pathogenesis-Related 1 Proteins-Roles in Reproduction, Cancer, and Immune Defense. Endocrine Reviews, v. 29, n. 7, p. 865-897, 2008. doi: 10.1210/er.2008-003 
GODO, A.; BLANCO, J.; VIDAL, F; ANTON, E. Accumulation of numerical and structural chromosome imbalances in spermatozoa from reciprocal translocation carriers. Human Reproduction, v. 28, n. 3, p. 840-849, 2013. doi:10.1093/humrep/des431

GU, A.; JI, G.; SHI, X.; LONG, Y.; XIA, Y.; SONG, L.; WANG, S.; WANG, X. Genetic variants in Piwi-interacting RNA pathway genes confer susceptibility to spermatogenic failure in a Chinese population. Human Reproduction, v. 25, n. 12, p. 2955-2961, 2010. doi:10.1093/humrep/deq274

GUDELOGLU, A.; PAREKATTIL, S. J. Update in the evaluation of the azoospermic male. Clinics, v. 68, n. S1, p. 27-34, 2013. doi:10.6061/clinics/2013(Sup01)04

HALDER, A.; KUMAR, P.; JAIN, M.; LYER, V. K. Copy number variations in testicular maturation arrest. Andrology, v. 5, n. 3, p. 460-472, 2017. doi:10.1111/andr.12330

HAMMOUD, S. S.; NIX, D. A.; HAMMOUD, A. O.; GIBSON, M.; CAIRNS, B. R.; CARRELL, D. T. Genome-wide analysis identifies changes in histone retention and epigenetic modifications at developmental and imprinted gene loci in the sperm of infertile men. Human Reproduction, v. 26, n. 9, p. 2558-2569, 2011. doi:10.1093/humrep/der192

HAN, H.; LIU, S.; ZHOU, X.-G.; TIAN, L.; ZHANG, X.-D. Aetiology of obstructive azoospermia in Chinese infertility patients. Andrologia. v. 48, n. 7, p. 761-764, 2016. doi:10.1111/and.12509

HAREL, T.; LUPSKI, J. R.; Genomic disorders 20 years on - mechanisms for clinical manifestations. Clinical Genetics, p. 1-11, 2017. doi: 10.1111/cge.13146 IN PRESS

HE, Z.; FENG, L.; ZHANG, X.; GENG, Y.; PARODI, D. A.; SUAREZ-QUIAN, C.; DYN, M. Expression of Col1a1, Col1a2 and procollagen I in germ cells of immature and adult mouse testis. Reproduction Research, v. 130, p. 333-341, 2005. doi:10.1530/rep.1.00694

HIRSH, A. Male subfertility. British Medical Journal, v. 327, n. 7416, p. 669-672, 2003. doi:10.1136/bmj.327.7416.669

HOOK, E. B. Exclusion of chromosomal mosaicism: tables of $90 \%$, 95\% and 99\% confidence limits and comments on use. American Journal of Human Genetics, v. 29, n. 1, p. 94-97, 1977.

HOTALING, J. M. Genetics of male infertility. Urologic Clinics of North America, v. 41, n. 1, p. 1-17, 2014. doi:10.1016/j.ucl.2013.08.009

HOTALING, J. M.; CARRELL, D. T. Clinical genetic testing for male factor infertility: current applications and future directions. Andrology, v. 2, n. 3, p. 339-350, 2014. doi:10.1111/j.2047-2927.2014.00200.x

HOFFMANN, H. M.; TRANG, C.; GONG, P.; KIMURA, I.; PANDOLFI, E. C.; MELLON, P. L. Deletion of Vaxl from Gonadotropin-Releasing Hormone (GnRH) Neurons Abolishes GnRH Expression and Leads to Hypogonadism and Infertility. The Journal of Neuroscience, v. 36, n. 12, p. 3506-3518, 2016. doi: 10.1523/JNEUROSCI.2723-15.2016 
HUANG, W. J.; YEN, P. H. Genetics of spermatogenic failure. Sexual Development, v. 2, n. 4-5, p. 251-259, 2008. doi:10.1159/000152041

IBRAHIM, E.; BRACKETT, N. L.; LYNNE, C. M. Advances in the management of infertility in men with spinal cord injury. Asian Journal of Andrology. v. 18, n. 3, p. 382390, 2016. doi:10.4103/1008-682X.178851

INHORN, M. C.; PATRIZIO, P. Infertility around the globe: new thinking on gender, reproductive technologies and global movements in the 21 st century. Human Reproduction Update, v. 21, n. 4, p. 411-426, 2015. doi:10.1093/humupd/dmv016

JAISWAL, D.; TRIVEDI, S.; AGRAWAL, N. K.; SINGH, K.; Dysregulation of apoptotic pathway candidate genes and proteins in infertile azoospermia patients. Fertility and Sterility, v.104, n. 3, p. 736-743e.6, 2015. doi:10.1016/j.fertnstert.2015.05.029

JENSEN, C. F. S.; ØSTERGREN, P.; DUPREE, J. M.; OHL, D. A.; SØNKSEN, J.; FODE, M. Varicocele and male infertility. Nature Reviews Urology, v.14, n. 9, p.523-533, 2017. doi:10.1038/nrurol.2017.98

JIANG, L.; JIN, J.; WANG, S.; ZHANG, F.; DAI, Y.; SHI, L.; ZHANG, S. CFTR gene mutations and polymorphism are associated with nonobstructive azoospermia: From casecontrol study. Gene, v. 626, p. 282-289, 2017. doi:10.1016/j.gene.2017.04.044

JIANG, W.; ZHU, P.; ZHANG, J.; WU, Q.; LI, W.; LIU, S.; NI, M.; YO, M.; CAO, J.; LI, Y.; CUI, Y.; XIA, X.; Polymorphisms of protamine genes contribute to male infertility susceptibility in the Chinese Han population. Oncotarget, v. 8, n. 37, p. 61637-61645, 2017. doi:10.18632/oncotarget.18660

JOHNSON, E.C.; BJJLLAND, D. W.; HOWRIGAN, D. P.; ABDELLAOUI, A.; BREEN, G.; BORGLUM, A. No Reliable Association between Runs of Homozygosity and Schizophrenia in a Well-Powered Replication Study. Plos Genetics, v. 12, n.10, 2016. doi: 10.1371/journal.pgen.1006343

JUNGWIRTH, A.; DIEMER, T.; DOHLE, G. R.; GIWERCMAN, A.; KOPA, Z.; KRAUSZ, C.; TOURNAYE, H. Guidelines on Male Infertility. European Association of Urology, 2015.

JUUL, A.; ALMSTRUP, K.; ANDERSSON, A-M.; JENSEN, T. K.; JORGENSEN, N.; MAIN, K. M.; RAJPERT-DE MEYTS, E.; TOPPARI, J.; SKAKKEBAEK, N. E. Possible fetal determinants of male infertility. Nature Reviews Endocrinology, v. 10, n.9, p. 553562, 2014. doi:10.1038/nrendo.2014.97

KHERRAF, Z-E.; CHRISTOU-KENT, M.; KARAOUZENE, T.; AMIRI-YEKTA, A.; MARTINEZ, G.; VARGAS, A.S.; LAMBERT, E.; BOREL, C.; DORPHIN, B.; AKNINSEIFER, I.; MITCHELL, M. J.; METZLER-GUILLERMAIN, C.; ESCOFFIER, J.; NEF, S.; GREPILLAT, M.; THIERRY-MIEG, N.; SATRE, V.; BAILLY, M.; BOITRELLE, F.; PERNET-GALLAY, K.; HENNEBICQ, S.; FAURÉ, J.; BOTTARI, S. P.; COUTTON, C.; RAY, P. F.; ARNOULT, C. SPINK2 deficiency causes infertility by inducing sperm defects in heterozygotes and azoospermia in homozygote. EMBO Molecular Medicine, v. 9, n. 8, p. 1132-1149, 2017. doi:10.15252/emmm.201607461 
KOVAC J. R.; PATUSZAK, A. W.; LAMB, D. J. The use of genomics, proteomics, and metabolomics in identifying biomarkers of male infertility. Fertility and Sterility, v. 99, n. 4, p. 998-1007, 2013. doi:10.1016/j.fertnstert.2013.01.111

KRAUSZ, C.; CASAMONTI, E. Spermatogenic failure and the Y chromosome. Human Genetics, v. 136, n. 5, p. 637-655, 2017. doi:10.1007/s00439-017-1793-8

KRAUSZ, C.; ESCAMILLA, A. R.; CHIANESE, C.; Genetics of male infertility: from research to clinic. Reproduction, v. 150, n. 5, p. R159-174, 2015. doi:10.1530/REP-150261

KRAUSZ, C.; GIACHINI, C.; LO GIACCO, D.; DAGUIN, F.; CHIANESE, C; ARS, E.; RUIZ CASTANE, E.; FORTI, G.; ROSSI, E. High resolution X chromosome specific arrayCGH detects new CNVs in infertile males. Plos One, v. 7, n. 10, p. e44887, 2012. doi:10.1371/journal.pone.0044887

KRAUSZ, C.; HOEFSLOOT, L.; SIMONI, M.; TÜTTELMANN, F. Academy European, of Andrology, European Molecular Genetics Quality Network EAA/EMQN best practice guidelines for molecular diagnosis of Y-chromosomal microdeletions: state-of-the-art 2013. Andrology, v. 2, n. 1, p. 5-19, 2014. doi:10.1111/j.2047-2927.2013.00173.x

KUMAR, N.; SINGH, A. K.; Trends of male factor infertility, an important cause of infertility: A review of literature. Journal of Human Reproductive Sciences, v. 8, n. 4, p. 191-196, 2015. doi:10.4103/0974-1208.170370

LACERDA, J. I.; DEL GUIUDICE, P. T.; SILVA, B. F.; NICHI, M.; FARIELLO, R.M.; FRAIETTA, R.; RESTELLI, A. E.; BLUMER, C. G.; BERTOLLA, R. P.; CEDENHO, A. P. Adolescent varicocele: improved sperm function after varicocelectomy. Fertility and Sterility, v. 95, n. 3, p. 994-999, 2011. doi:10.1016/j.fertnstert.2010.10.031

LAHN, B. T.; TANG, Z. L.; ZHOU, J.; BARNDT, R. J.; PARVINEN, M.; ALLIS, C. D.; PAGE, D. C. Previously uncharacterized histone acetyltransferases implicated in mammalian spermatogenesis. PNAS, v. 99, n. 13, p. 8707-8712, 2002. doi: 10.1073_pnas.082248899

LAI, Y-C.; WANG, W-C.; YANG, J-J.; LI, S-Y. Expansion of CAG repeats in the spinocerebellar ataxia type 1 (SCAN1) gene in idiopathic oligozoospermia patients. Journal of assisted reproduction and genetics, v. 26, n. 5, p. 257 - 261, 2009. doi:10.1007/s10815009-9325-7

LASSILA, M.; JUHILA, J.; HEIKKILA, E.; HOLTHÖFER, H. Densin is a Novel Cell Membrane Protein of Sertoli Cells in the Testis. Molecular Reproduction and Development, v. 74, p. 641-645, 2007. doi:10.1002/mrd.20659

LEAVER, R. B.; Male infertility: an overview of causes and treatment options. British Journal of Nursing (Urology Supplement), v. 25, n. 18, p. S35-40, 2016. doi:10.12968/bjon.2016.25.18.S35 
LEE, C.; IAFRATE, A. J.; BROTHMAN, A.R.; Copy number variations and clinical cytogenetic diagnosis of constitutional disorders. Nature Genetics, v. 39, n. 7s, p. S48-S54, 2007. doi:10.1038/ng2092

LI, L-J; ZHANG, F-B; LIU, S-Y.; TIAN, Y-H.; LE, F.; LOU, H-L.; HUANG, H-F.; JIN, F.; Decreased expression of SAM68 in human testes with spermatogenic defects. Fertility and Sterility, v. 102, n. 1, p. 61-67e3, 2014. doi:10.1016/j.fertnstert.2014.03.036

LIN, Y-W.; HSU, C-L. L.; KUO, P-L.; HUANG, W. J.; CHIANG, H-S.; YEH, S-D.; HSU, T-Y.;YU, Y-H.; HSIAO, K-N.; CANTOR, R. M.; YEN, P. H. Partial Duplication at AZFc on the Y Chromosome Is a Risk Factor for Impaired Spermatogenesis in Han Chinese in Taiwan. Human Mutation, v. 28, n. 5, p. 486-494, 2007. doi: 10.1002/humu.20473

LIU, G.; SHI, Q. W.; LU, G. X. A newly discovered mutation in PICK1 in a human with globozoospermia. Asian Journal of Andrology, v. 12, n. 4, p. 556-560, 2010. doi:10.1038/aja.2010.47

LOPES, A. M.; ASTON, K. I.; THOMPSON, E.; CARVALHO, F.; GONÇALVES, J.; HUANG, N.; MATTHIESEN, R.; NOORDAM, M. J.; QUINTELA, I.; RAMU, A.; SEABRA, C.; WILFERT, A. B.; DAI, J.; DOWNIE, J. M.; FERNANDES, S.; GUO, X.; SHA, J.; AMORIM, A.; BARROS, A.; CARRACEDO, A.; HU, Z.; HURLES, M. E.; MOSKOVTSEV, S.; OBER, C.; PADUCH, D. A.; SCHIFFMAN, J. D.; SCHLEGEL, P. N.; SOUSA, M.; CARRELL, D. T.; CONRAD, D. F. Human Spermatogenic Failure Purges Deleterious Mutation Load from the Autosomes and Both Sex Chromosomes, including the Gene DMRT1. Plos Genetics, v. 9, n. 3, p. 1-16, 2013. doi:10.1371/journal.pgen.1003349

LOUIS, J. F.; THOMA, M. E.; SØRENSEN, D. N.; McLAIN, A. C.; KING, R. B.; SUNDARAM, R.; KEIDING, N.; LOUIS, G. M. B. The prevalence of couple infertility in the Unites States from male perspective: evidence from a nationally representative sample. Andrology, n. 1, v. 5, p. 741-748, 2013. doi:10.1111/j.2047-2927.2013.00110.x

LU, C.; JIANG, J.; ZHANG, R.; WANG, Y.; XU, M.; QIN, Y.; LIN, Y.; GUO, X.; NI, B.; ZHAO, Y.; DIAO, N.; CHEN, F.; SHEN, H.; SHA, J.; XIA, Y.; HU, Z.; WANG, X. Gene copy number alterations in the azoospermia-associated AZFc region and their effect on spermatogenic impairment. Molecular Human Reproduction, v. 10, p. 1-8, 2014. doi:10.1093/molehr/gau043

MAJUMDAR, S. S., BHATTACHARYA I. Genomic and post-genomic leads toward regulation of spermatogenesis. Progress in Biophysics and Molecular Biology, v. 113, n. 3, p. 409-422, 2013. doi:10.1016/j.pbiomolbio.2013.01.002

MASSART, A.; LISSENS, W.; TOURNAYE, H.; STOUFFS, K. Genetic causes of spermatogenic failure. Asian Journal of Andrology, v. 14, n. 1, p. 40-48, 2012. doi:10.1038/aja.2011.67

McLACHLAN, R.I.; O'BRYAN, M. K. State of the art for genetic testing of infertile men. The Journal of Clinical Endocrinology \& Metabolism, v. 95, n. 3, p. 1013-1024, 2010. doi:10.1210/jc.2009-1925 
MICHAELSON, J J. Genetic approaches to understanding psychiatric disease. Neurotherapeutics, v. 14, n. 3, p. 568-581, 2017. doi:10.1007/s13311-017-0551-x

MITCHELl, M. J.; METZleR-GUILlEMAIN, C.; TOURE, A.; COUTTON. C.; ARNOULT, C.; RAY, P.F. Single gene defects leading to sperm quantitative anomalies. Clinical Genetics, v. 91, n. 2, p. 208-216, 2017. doi:10.1111/cge.12900

MITTAL, P. K.; LITTLE, B.; HARRI, P. A.; MILLER, F. H.; ALEXANDER, L. F.; KALB, B.; CAMACHO, J. C.; MASTER, V.; HARTMAN, M.; MORENO, C. Role of Imaging in the Evaluation of Male Infertility. RadioGraphics, v. 37, p. 837-854, 2017. doi:10.1148/rg.2017160125

MIYAMOTO, T.; MINASE, G.; SHIN, T.; UEDA, H.; OKADA, H.; SENGOKU, K. Human male infertility and its genetic causes. Reproductive Medicine and Biology, v. 16, n.2, p. 81-88, 2017. doi: 10.1002/rmb2.12017

MODGIL, V.; RAI, S.; RALPH, D. J.; MUNEER, A. An update on the diagnosis and management of ejaculatory duct obstruction. Nature Reviews Urology, v. 13, n. 1, p. 13-20, 2016. doi:10.1038/nrurol.2015.276

MONTJEAN, D.; DE LA GRANGE, P.; GENTIEN, D.; RAPINAT, A.; BELLOC, S.; COHEN-BACRIE, P.; MENEZO, Y.; BENKHALIFA, M. Sperm transcriptome profiling in oligozoospermia. Journal of Assisted Reproduction and Genetics, v. 29, n. 1, p. 3-10, 2012. doi:10.1007/s10815-011-9644-3

MOORHEAD, P. S.; NOWELL, P. C.; MELLMAN, W. J.; BATTIPS, D. M.; HUNGERFORD, D. A. Chromosome preparations of leucocytes cultured from human peripheral blood. Experimental Cell Research, v. 20, n. 3, p. 613-616, 1960. doi:10.1016/0014-4827(60)90138-5

MUMTAZ, A.; KHALID, A.; JALIL, Z.; FATIMA S. S.; ARIF, S.; REHMAN, R. Kisspeptin: a potential factor for unexplained infertility and impaired embryo implantation. Internal Journal of Fertility \& Sterility, v. 11, n. 2, p. 99-104, 2017. doi:10.22074/ijfs.2017.4957

NAGIRNAJA, L.; VIGH-CONRAD, K.; CONRAD, D. F.; How to map the genetic basis for conditions that are comorbid with male infertility. Seminars in Reproductive Medicine, v. 35, n. 3, p. 225-230, 2017. doi:10.1055/s-0037-1603567

NAKAMURA, S.; MIYADO, M.; SAITO, K.; KATSUMI, M.; NAKAMURA, A.; KOBORI, Y.; TANAKA, Y.; ISHIKAWA, H.; YOSHIDA, A.; OKADA, H.; HATA, K.; NAKABAYASHI, K.; OKAMURA, K.; OGATA, H.; MATSUBARA, Y.; OGATA, T.; NAKAI, H.; FUKAMI, M. Next-generation sequencing for patients with non-obstructive azoospermia: implications for significant roles of monogenic/ oligogenic mutations. Andrology, v. 5, p. 824-831, 2017. doi: 10.1111/andr.12378

NARGUND, V. H.; Effects of psychological stress on male fertility. Nature Reviews Urology, v. 12, n. 7, p. 373-382, 2015. doi: 10.1038/nrurol.2015.112 
NATIONAL INSTITUTE OF HEALTH (NIH). US National Library of Medicine. Genetics Home Reference. Chromosomes \& mtDNA. Y Chromosome. Disponível em: https://ghr.nlm.nih.gov/chromosome/Y. Acesso em 3 de setembro de 2017

NAVARRO-COSTA, P.; PLANCHA, C. E.; GONÇALVES, J. Genetic dissection of the AZF regions of the human Y chromosome: thriller or filler for male (in)fertility? Journal of Biomedicine and Biotechnology, vol. 2010, p. 1-18, 2010. doi:10.1155/2010/936569

NETO, F. T. L.; BACH, P. V.; NAJARI, B. B.; LI, P. S.; GOLDESTEIN, M. Genetics of Male Infertility. Current Urology Reports, v. 17, n. 70, p. 1-12, 2016. doi:10.1007/s11934016-0627-x

NISHIDE, M.; KUMANOGOH, A. The role of semaphorins in immune responses and autoimmune rheumatic diseases. Nature Reviews Rheumatology, v. 14, n.1, p. 19-31, 2018. doi: 10.1038/nrrheum.2017

NOWAKOWSKA, B. Clinical interpretation of copy number variants in the human genome. Journal of Applied Genetics, vol. 58, p. 449-457, 2017. doi: 10.1007/s13353-017-0407-4

O'FLYNN O'BRIEN K. L.; VARGHESE A. C.; AGARWAL, A. The genetic cause of male factor infertility: A review. Fertility and Sterility, v. 93, n. 1, p. 1-12, 2010. doi: 10.1016/j.fertnstert.2009.10.045

ONG, T.; MARSHALL, S.G.; KARCZESKI, B.A.; STERNEN, D. L.; CHENG, E.; CUTTING, G. R.; In: PAGON, R. A.; ADAM, M.P.; ARDINGER, H. H.; WALLACE, S. E.; AMEMIYA, A.; BEAN, L. J. H.; BIRD, T. D.; LEDBETTER, N.; MEFFORD, H. C.; SMITH, R. J. H.; STEPHENS, K. (eds.) GeneReviews ${ }^{\circledR}$ [Internet]. Seattle (WA): University of Washington, Seattle; 1993-2017.

OSBORNE, E. C.; LYNCH, M.; McLACHLAN, R.; TROUSON, A. O.; CRAM, D. S. Microarray detection of $\mathrm{Y}$ chromosome deletions associated with male infertility. Reproductive BioMedicine Online, v. 34, n. 1, p. 75-81, 2007. doi:10.1016/j.rbmo.2016.09.010

PARMENTIER, M.; LIBERT, F.; SCHURMANS, S.; SCHIFFMANN, S.; LEFORT, A.; EGGERICKX, D.; LEDENT, C.; MOLLEREAU, C.; GÓRARD, C.; PERRET, J.; GROOTEGOED, A.; VASSART, G. Expression of members of the putative olfactory receptor gene family in mammalian germ cells. Nature, v. 355, n. 453, 1992. doi: $10.1038 / 355453 \mathrm{a} 0$

POLLACK, J. R.; PEROU, C. M.; ALIZADEH, A. A.; EISEN, M. B.; PERGAMENCHIKOV, A.; WILLIAMS, C. F.; JEFFREY, S. S.; BOTSTEIN, D.; BROWN, P. O. Genome-wide analysis of DNA copy-number changes using cDNA microarrays. Nature Genetics, v. 23, n. 1, p. 41-46, 1999. doi:10.1038/12640

PRANDO, E. C.; CAVALLI, L. R.; RAINHO, C. A.; Evidence of epigenetic regulation of the tumor suppressor gene cluster flanking RASSF1 in breast cancer cell lines. Epigenetics, v. 6, n. 12, p. 1413-1424, 2011. doi: 10.4161/epi.6.12.18271 
PYLYP, L. Y.; SPINENKO, L. O.; VERHOGLYAD, N. V.; ZUKIN, V. D. Chromosomal abnormalities in patients with oligozoospermia and non-obstructive azoospermia. Journal of Assisted Reproduction and Genetic, v. 30, n. 5, p. 729-732, 2013. doi:10.1007/s10815013-9990-4

RAJENDER, S.; AVERY, K.; AGARWAL, A. Epigenetics, spermatogenesis and male infertility. Mutation Research, v. 727, n. 3, p. 62-71, 2011. doi:10.1016/j.mrrev.2011.04.002

RAMALINGAM, M.; KINI, S.; MAHMOOD, T. Male fertility and infertility. Obstetrics, Gynaecology and Reproductive Medicine, v. 24, n. 11, p. 326-332, 2014. doi: 10.1016/j.ogrm.2014.08.006

RASTEGAR, D. A.; TABAR, M. S.; ALIKHANI M.; PARSAMATIN, P.; SAMANI, F. S.; SABBAGHIAN, M.; GILANI, M. A. S.; AHADI, A. M.; MEYBODY, A. M.; PIRYAEI, A.; ANSARI-POUR, N.; GOURABI, H.; BAHARVAND, H.; SALEKDEH, G. H. Isoformlevel gene expression profiles of human Y chromosome azoospermia factor genes and their $\mathrm{X}$ chromosome paralogs in the testicular tissue of non-obstructive azoospermia patients. Journal of Proteome Research, v. 14, n. 9, p. 3595-3605, 2015. doi:10.1021/acs.jproteome.5b00520

RATO, L.; ALVES, M. G.; SOCORRO, S.; DUARTE, A. I.; CAVACO, J. E.; OLIVEIRA, P. F.; Metabolic regulation is important for spermatogenesis. Nature Reviews Urology, v. 9, n. 6, p. 330-338, 2012. doi:10.1038/nrurol.2012.77

RAY, P. F.; TOURE, A.; METZLER-GUILLEMAIN, C.; MITCHELL, M. J.; ARNOULT, C.; COUTTON. C. Genetic abnormalities leading to qualitative defects of sperm morphology or function. Clinical Genetics, v. 91, p. 217-232, 2017. doi:10.1111/cge.12905

REIDY, K.; TUFRO, A. Semaphorins in kidney development and disease: modulators of ureteric bud branching, vascular morphogenesis, and podocyteendothelial crosstalk. Pediatric Nephrology, v. 26, n. 9, p. 1407-1412, 2011. doi:10.1007/s00467-011-1769-1.

REPPING, S.; SKALETSKY, H.; LANGE, J.; SILBER, S.; VAN DER VEEN, F.; D'OATES, R.; PAGE, D. C.; ROZEN, S. Recombination between palindromes P5 and P1 on the human $\mathrm{Y}$ chromosome causes massive deletions and spermatogenic failure. American Journal of Human Genetics, v. 71, n. 4, p. 906-922, 2002. doi:10.1086/342928

RÖPKE, A.; TÜTTELMANN, F. Aberrations of the X chromosome as cause of male infertility. European Journal of Endocrinology, 2017. IN PRESS. doi:10.1530/EJE-170246

ROSENFELD, J. A.; PATEL, A. Chromosomal microarrays: understanding genetics of neurodevelopmental disorders and congenital anomalies. Journal of Pediatric Genetics, vol. 6, n. 1, p. 42-50, 2017. doi:10.1055/s-0036-1593842

ROUKOS, V.; MISTELI, T. The biogenesis of chromosome translocations. Nature Cell Biology, v.16, n. 4, p. 293-300, 2014. doi:10.1038/ncb2941 
SADEGHI-NEJAD, H.; FARROKHI, F. Genetics of azoospermia: current knowledge, clinical implications, and future directions. Part II Y chromosome microdeletions. Urology Journal, v. 4, n. 4, p. 192-206, 2007. doi:10.22037/uj.v4i4.97

SAFARINEJAD, M. R.; SHAFIEI, N.; SAFARINEJAD, S. The role of endothelial nitric oxide synthase (eNOS) T-786C, G894T, and 4a/b gene polymorphisms in the risk of idiopathic male infertility. Molecular Reproduction \& Development, v. 77, n. 8, p. 720727, 2010. doi:10.1002/mrd.21210

SAHIN, F. I.; YILMAZ, Z.; YUREGIR, O. O.; BULAKBASI, T.; OZER, O.; ZEYNELOGLU, H. B. Chromosome heteromorphisms: an impact on infertility. Journal of Assisted Reproductive and Genetics, vol. 25, n. 5, p. 191-195, 2008. doi:10.1007/s10815008-9216-3

SAMPLASKI, M. K.; NANGIA, A. K. Adverse effects of common medications on male fertility. Nature Reviews Urology, v. 12, n. 7, p. 401-413, 2015. doi:10.1038/nrurol.2015.145

SCHAGDARSURENGIN, U.; PARADOWSKA, A.; STEGER, K. Analysing the sperm epigenome: roles in early embryogenesis and assisted reproduction. Nature Reviews Urology, v. 9, n. 11, p. 609-619, 2012. doi:10.1038/nrurol.2012.183

SCHERES, J. M. J. C. Human chromosome banding. The Lancet, vol.299, n. 7755, p.849, 1972. doi:10.1016/S0140-6736(72)90835-5

SCHULTZ, N.; HAMRA, F. K.; GARBERS, D. A multitude of genes expressed solely in meiotic or postmeiotic spermatogenic cells offers a myriad of contraceptive targets. Proceedings of the National Academy of Sciences of the United States of America, v.100, n. 21, p.12201-12206, 2003. doi:10.1073/pnas.1635054100

SHEN, Y.; XU, J.; YANG, X.; LIU, Y.; MA, Y.; YANG, D.; DONG, Q.; YANG, Y. Evidence for the involvement of the proximal copy of the MAGEA9 gene in Xq28-linked CNV67 specific to spermatogenic failure. Biology Reproduction, v. 96, n. 3, p. 610-616, 2017. doi:10.1093/biolre/iox006

SHINKA, T.; SATO, Y.; CHEN, G.; NARODA, T.; KINOSHITA, K.; UNEMI, Y.; TSUJI, K.; TOIDA, K.; IWAMOTO, T.; NAKAHORI, Y. Molecular characterization of heat shocklike factor encoded on the human Y chromosome, and implications for male infertility. Biology of reproduction, v.71, n. 1, p. 297-306, 2004. doi:10.1095/biolreprod.103.023580

SHIRAISHI, K.; NAITO, K. Involvement of vascular endothelial growth factor on spermatogenesis in testis with varicocele. Fertility and Sterility, v. 90, n. 4, p. 1313-1316, 2008. doi:10.1016/j.fertnstert.2007.08.030

SILBER, S.J.; DIETECHE, C. M. Y chromosome infertility. In: PAGON, R. A.; ADAM, M.P.; ARDINGER, H. H.; WALLACE, S. E.;AMEMIYA, A.;BEAN, L. J. H.; BIRD, T. D.; LEDBETTER, N.; MEFFORD, H. C.; SMITH, R. J. H.; STEPHENS, K. (eds.) GeneReviews ${ }^{\circledR}$ [Internet]. Seattle (WA): University of Washington, Seattle; 2012. 
SINGH, R.; HAMADA, A. J.; BUKAVINA, L.; AGARWAL, A. Physical deformities relevant to male infertility. Nature Reviews Urology, v. 9, n. 3, p.156-174, 2012. doi:10.1038/nrurol.2012.11

SKAKKEBAEK N.E, JORGENSEN N, MAIN K. M; MEYETS, E. R.; LEFFERS, H.; ANDERSSON, A. M.; JUUL, A., CARLSEN, E., MORTENSEN, G. K.; JENSEN, T. K.; TOPPARI, J. Is human fecundity declining? International Journal of Andrology, v. 29, n. 1, p. 2-11, 2006. doi:10.1111/j.1365-2605.2005.00573.x

SKALETSKY, H.; KURODA-KAWAGUCHI, T.; MINX, P. J.; CORDUM, H. S.; HILLIER, LD.; BROWN, L. G.; REPPING, S.; PYNTIKOVA, T.; ALI, J.; BIERI, T.; CHINWALLA, A.; DELEHAUNTY, A.; DELEHAUNTY, K.; DU, H.; FEWELL, G.; FULTON, L.; FULTON, R.; GRAVES, T.; HOU, SF.; LATRIELLE, P.; LEONARD, S.; MARDIS, E.; MAUPIN, R.; MCPHERSON, J.; MINER, T.; NASH, W.; NGUYEN, C.; OZERSKY, P.; PEPIN, K.; ROCK, S.; ROHLFING, T.; SCOTT, K.; SCHULTZ, B.; STRONG, C.; TIN-WOLLAM, A.; YANG, SP.; WATERSON, R.; WILSON, R. K.; ROZEN, S.; PAGE, D. C. The male-specific region of the human Y chromosome is a mosaic of discrete sequence classes. Nature, v. 423, n. 6942, p. 825-837, 2003. doi: $10.1038 /$ nature 01722

SMITH, R. S.; COWARD, R. M.; LIPSHULTZ, L. I. The office visit. Urologic Clinics of North America, v. 41, n. 1, p. 19-37, 2014. doi:10.1016/j.ucl.2013.08.002

SONG, SH.; CHIBA, K.; RAMASAMY, R.; LAMB, D. J. Recent advances in the genetics of testicular failure. Asian Journal of Andrology, v. 18, n. 3, p. 350-355, 2016. doi:10.4103/1008-682X.178857

STAHL, P. J.; SCHLEGEL, P. N. Genetic evaluation of the azoospermic or severely oligozoospermic male. Current Opinion in Obstetrics and Gynecology, v. 24, n. 4, p. 221 228, 2012. doi:10.1097/GCO.0b013e3283558560

STOUFFS, K.; VANDERMAELEN, D.; MASSART, A.; MENTEN, B.; VERGULT, S. TOURNAYE, H. LISSENS, W. Array comparative genomic hybridization in male infertility. Human Reproduction, v. 27, n. 3, p. 921-929, 2012. doi:10.1093/humrep/der440

STOUFFS, K.; GHELDOF, A.; TOURNAYE, H.; VANDERMAELEN, D.; BONDUELLE, M.; LISSENS, W.; SENECA, S. Sertoli Cell-Only Syndrome: Behind the Genetic Scenes. BioMed Research International, v. 2016, p. 1-7, 2015. doi: 10.1155/2016/6191307

STRACHAN, T.; READ, A. Genética Molecular Humana, 4 edição, Porto Alegre: Artmed, 2013.

SUGANYA, J.; KUJUR, S. B.; SELVARAH, K.; SURULI, M. S.; HARIPRIYA, G.; SAMUEL, C. R. Chromosomal abnormalities in infertile men from Southern India. Journal of Clinical and Diagnostic Research, v. 9, n. 7, p. 5-10, 2015. doi:10.7860/JCDR/2015/14429.6247

SU, D.; ZHANG, W.; YANG, Y.; ZHANG, H.; LIU, Y.Q.; BAI, G.; MA, Y.X.; PENG, Y.; ZHANG, S.Z. c.822+126T>G/C: a novel triallelic polymorphism of the TSSK6 gene 
associated with spermatogenic impairment in a Chinese population. Asian Journal of Andrology, v. 12, n. 2, p. 234 - 239, 2009. doi:10.1038/aja.2009.80

SZCZALUBA, K.; DEMKOW, U. Array comparative genomic hybridization and genomic sequencing in the diagnostics of the causes of congenital anomalies. Journal of Applied Genetics, v. 58, n. 2, p. 185-198, 2017. doi:10.1007/s13353-016-0376-Z

TEMPEST, H. G.; SIMPSON, J. L. Why are we still talking about chromosomal heteromorphisms? Reproductive BioMedicine Online, v. 35, n. 1, p. 1-2, 2017. Editorial doi:10.1016/j.rbmo.2017.05.006

TEWES, A. C.; LEDIG, S.; TEUTTLMANN, F.; KLIESCH, S.; WIEACKER, P. DMRT1 mutations are rarely associated with male infertility. Fertility and Sterility, v. 102, n. 3, p. 816-820.e3, 2014. doi:10.1016/j.fertnstert.2014.05.022

THONNEAU P.; MARCHAND S.; TALLEC A.; FERIAL, M. L.; DUCOT, B., LANSAC, J.; LOPES, P.; TABASTE, J. M.; SPIRA, A. Incidence and main causes of infertility in a resident population $(1,850,000)$ of three French regions (1988-1989). Human Reproduction, v. 6, n. 6, p. 811-816, 1991. doi:10.1093/oxfordjournals.humrep.a137433

TOURNAYE, H.; KRAUSZ, C.; DOATES, R.; Novel concepts in the aetiology of male reproductive impairment. The Lancet: Diabetes \& Endocrinology, v. 5, n. 7, p. 544-553. 2016. doi:10.1016/S2213-8587(16)30040-7

TÜTTELMANN, F.; SIMONI, M.; KLIESCH, S.; LEDIG, S.; DWORNICZAK, B.; WIEACKER, P.; ROPKE, A. Copy number variation in patients with severe oligozoospermia and Sertoli-cell only syndrome. Plos One, v.6, n. 4, p. e19426, 2011. doi:10.1371/journal.pone.0019426

UEDA, J.; HARADA, A.; URAHAMA, T.; MACHIDA, S.; MAEHARA, K.; HADA, M.; MAKINO, Y.; NOGAMI, J.; HORIKOSHI, N.; OSAKABE, A.; TAGUCHI, H.; TANAKA, H.; TACHIWANNA, H.; YAO, T.; YAMADA, M.; IWAMOTO, T.; ISOTANI, A.; IKAWA, M.; TACHIBANA, T.; OKADA, Y.; KIMURA, H.; OHKAWA, Y.; KURUMIZAKA, H.; YAMAGATA, K. Testis-Specific Histone Variant H3t Gene Is Essential for Entry into Spermatogenesis. Cell Reports, v. 18, n. 3, p. 593-600, 2017. doi: 10.1016/j.celrep.2016.12.065

VALDEMBRI, D.; REGANO, D.; MAIONE, F.; GIRAUDO, E.; SERINI, G. Class 3 semaphorins in cardiovascular development. Cell Adhesion \& Migration, v. 10, n. 6, p. 641651, 2016. doi:10.1080/19336918.2016.1212805

VANI, G. T.; MUKESH, N.; PRASAD, B. S.; DEVI, P. R.; PRASAD, M. H.; RANI, P. U.; REDDY, P. P. Role of glutathione S-transferase Mu-1 (GSTM1) polymorphism in oligospermic infertile males. Andrologia, v. 42, n. 4, p. 213-217, 2010. doi:10.1111/j.14390272.2009.00971.x

VISSER, L.; WESTERVELD, G. H.; XIE, F.; VAN DAALEN, S. K.; VAN DER VEEN, F.; LOMBARDI, M. P.; REPPING, S. A comprehensive gene mutation screen in men with asthenozoospermia. Fertility and Sterility, v. 95, n. 3, p. 1020-1024.e9, 2011. doi:10.1016/j.fertnstert.2010.11.067 
VOGT, P.; EDELMANN, A.; KIRSCH, S.; HENEGARIU, O.; HIRSCHMANN, P.; KIESEWETTER, F.; KOHN, F.M.; SCHILL, W.B.; FARAH, S.; RAMOS, C.; HARTMANN, M.; HARTSCHUH, W.; MESCHEDE, D.; BEHRE, H.M.; CASTEL, A.; NIESCHLAG, E.; WEIDNER, W.; GRONE, H.J.; JUNG, A.; ENGEL, W.; HAIDL, G. Human Y chromosome azoospermia factors (AZF) mapped to different subregions in Yq11. Human Molecular Genetics, v. 5, n. 7, p. 933-943. 1996. doi:10.1093/hmg/5.7.933

XIE, C.; CHEN, X.; LIU, Y.; WU, Z.; PING, P. Multicenter study of genetic abnormalities associated with severe oligospermia and non-obstructive azoospermia. Journal of International Medical Research, p. 1-8, 2017. doi:10.1177/0300060517718771

YANG, B.; MA, Y-Y.; LIU, Y-Q.; LI, L.; YANG, D.; TU, W-L.; SHEN, Y.; DONG, Q.; YANG, Y.; Common AZFc structure may possess the optimal spermatogenesis efficiency relative to the rearranged structures mediated by non-allele homologous recombination. Scientific Reports, v. 5, n. 10551, 2015. doi: 10.1038/srep10551

YANG, X.; YUAN, P.; LIANG, H.; WU, X.; LAI, L.; ZHANG, Y. Novel mutations and polymorphisms in the CFTR gene associated with three subtypes of Congenital Absence of Vas Deferens. Fertility and Sterility, v. 104, n. 5, p. 1268 - 1275.e2, 2015. doi:10.1016/j.fertnstert.2015.07.1143

YATSENKO, A. N.; ROY, A.; CHEN, R.; MA, L.; MURTHY, L. J.; YAN, W.; LAMB, D. J.; MATZUK, M. M. Non-invasive genetic diagnosis of male infertility using spermatozoa RNA: KLHL10 mutations in oligozoospermic patients impair homodimerization. Human Molecular Genetics, v.15, n. 23, p. 3411-3419, 2006. doi:10.1093/hmg/ddl417

YU, X. W.; WEI, Z. T.; JIANG, Y.T.; ZHANG, S. L. Y chromosome azoospermia factor region microdeletions and transmission characteristics in azoospermic and severe oligozoospermic patients. International Journal of Clinical and Experimental Medicine, v. 8, n. 9, p. 14634-14646, 2015.

YUEN, R. K. C.; MERKOULOVITCH, A.; MACDONALD, J. R.; VLASSCHAERT, M.; LO, K.; GROBER, E.; MARSHALL, C. R.; JARVI, K. A.; KOLOMIETZ, E.; SCHERER, S. W.; Development of a high-resolution Y-chromosome microarray for improved male infertility diagnosis. Fertility and Sterility, v. 101, n. 4, p. 1079-1085, 2014. doi:10.1016/j.fertnstert.2013.12.027

WANG, C.; YANG, C.; CHEN, X.; YAU, B.; YANG, C.; ZHU, C.; LI, L.; WANG, J.; LI, X.; SHAO, Y.; LIU, Y.; JI, J.; ZHANG, J.; ZEN, K.; ZHANG, C.Y.; ZHANG, C. Altered profile of seminal plasma microRNAs in the molecular diagnosis of male infertility. Clinical Chemistry, v. 57, n. 12, p. 1722-1731, 2011. doi:10.1373/clinchem.2011.169714

WANG, J.; PANG, G. S.; CHONG, S. S.; LEE, C. G. SNP web resources and their potential applications in personalized medicine. Current Drug Metabolism, v. 13, p. 978-990, 2012. doi:10.2174/138920012802138552

WANG, S.; STANIKA, R. I.; WANG, X.X.; HAGEN, J.; KENNEDY, X. M. B.; OBERMAIR, G. J.; COLBRAN, R. J.; LEE, A. Densin-180 Controls the Trafficking and Signaling of L-Type Voltage-Gated Cav1.2 Ca2 Channels at Excitatory Synapses. The 
Journal of Neuroscience, v. 37, n. 8, p. 4979-4691, 2017. doi:10.1523/JNEUROSCI.258316.2017

WANG, Y.; LI, W.; XIA, Y.; WANG, C.; TANG, T. T.; GUO, W.; LI, J.; ZHAO, X.; SUN, Y.; HU, J.; ZHEN, H.; ZHANG, X.; CHEN, C.; SHI, Y.; LI, L.; CAO, H.; DU, H.; LI, J. Identifying human genome-wide $\mathrm{CNV}, \mathrm{LOH}$ and UDP by targeted sequencing of selected region. Plos One, v. 4, n. 10, p. 1-18, 2015. doi:10.1371/journal.pone.0132537

WARNIER, M.; ROUDBARAKI, M.; DEROUICHE, S.; DELCOURT, P.; BOKHOBZA, A.; PREVARSKAYA, N.; MARIOT, P. CACNA2D2 promotes tumorigenesis by stimulating cell proliferation and angiogenesis. Oncogene, v. 34, p. 5383-5394, 2015. doi: 10.1038/onc. 2014.467

WESTERVELD, G. H.; KORVER, C. M.; VAN PELT, A. M. M.; LESCHOT, N. J.; VAN DER VEEN, F.; REPPING, S.; LOMBARDI, M. P. Mutations in the testis-specific NALP14 gene in men suffering from spermatogenic failure. Human Reproduction, v. 21, n. 12, p. 3178-3184, 2006. doi:10.1093/humrep/del293

WICHMAN, L.; SOMASUNDARAM, S.; BREIDEL, C.; VALEIRO, D. M.; McCARREY, J. R.; HODGES, C. A.; KHALIL, A. M. Dynamic expression of long non-coding RNAs reveals their potential roles in spermatogenesis and fertility. Biology of Reproduction, $v$. 97, n. 2, p. 313-323, 2017. doi: 10.1093/biolre/iox084. In PRESS

WINTERS, B. R., WALSH, T. J. The Epidemiology of male infertility. Urologic Clinics of North America, vol. 41, n. 1, p. 195-294, 2014. doi:10.1016/j.ucl.2013.08.006

WORLD HEALTH ORGANIZATION: WHO, Manual for the Standardized Investigation, Diagnosis and Management of the Infertile Male, 2000.

WORLD HEALTH ORGANIZATION: WHO Laboratory manual for the examination and processing of human semen, 5th ed. Geneva, WHO press, 2010.

WOSNITZER M.; GOLDESTEIN, M.; HARDY, M. P. Review of Azoospermia. Spermatogenesis, v. 4, n. 1, p. e28218-1- e28218-7, 2014. doi:10.4161/spmg.28218

ZEGERS-HOCHSCHILD F.; ADAMSON, G. D; DE MOUZON J.; ISHIHARA O.; MANSOUR, R.; NYGREN K.; SULLIVAN E.; VANDERPOEL, S. International Committee for Monitoring Assisted Reproductive Technology (ICMART) and the World Health Organization (WHO) revised glossary of ART terminology, 2009. Fertility and Sterility, v. 92, n. 5, p. 1520-1524, 2009. doi:10.1016/j.fertnstert.2009.09.009

ZHANG, H.; SU, D.; YANG, Y.; ZHANG, W.; LIU, Y.; BAI, G.; MA, M.; MA, Y.; ZHANG, S. Some single-nucleotide polymorphism of the TSSK2 gene may be associated with human spermatogenesis impairment. Journal of Andrology, v. 31, n. 4, p. 388-392, 2009. doi:10.2164/jandrol.109.008466

ZHANG, Z.; RUIVENKAMP, C.; STAAF, J.; ZHU, H.; BARBARO, M.; PETILLO, D.; ZHOO, S.K.; BORG, A.; FAN, Y.; SCHOUMANS, J. Detection of submicroscopic constitutional chromosome aberrations in clinical diagnostics: a validation of the practical 
performance of different array platforms. European Journal of Human Genetics, v.16, p.786-792, 2008. doi:10.1038/ejhg.2008.14

ZHENG, H-Y.; LI, Y.; SHEN, F-J; TONG, Y-Q. A novel universal multiplex PCR improves detection of AZFc Y-chromosome microdeletions. Journal of Assited Reproduction and Genetics, v. 31, n. 5, p. 613-620, 2014. doi:10.1007/s10815-014-0204-5

ZÖLLNER, S.; TESLOVICH, T. M. Using GWAS data to identify Copy Number Variants contributing to common complex diseases. Statistical Science, v. 24, n. 4, p. 530-546, 2009. doi: 10.1214/09-STS304

ZUFFARDI, O. TIEPOLO, L. Frequencies and types of chromosome abnormalities associated with human male infertility. In: CROSIGNANI, P. G.; RUBIN, B. L. (Org.). Genetic control of gamete production and function. Academic Press, New York, USA, 1982.

\section{Referências de portais da internet}

1000 genomes Project: www.1000genomes.org/(últimoacessoem: 12/2017)

DGV: http://dgv.tcag.ca/dgv/app/home (último acessoem: 12/2017)

GeneCards: www.genecards.org/ (último acesso em 12/2017)

NCBI: www.ncbi.nlm.nih.gov/pubmed/(último acesso em 12/2017)

UCSC: genome.ucsc.edu/ (último acesso em 12/2017)

OMIM: www.omim.org (último acesso em 12/2017) 
$\mathcal{A P} \hat{\mathcal{E}} \mathcal{N D I C E S}$ 


\section{APÊNDICES}

\section{APÊNDICE A - TERMO DE CONSENTIMENTO LIVRE E ESCLARECIDO}

Estamos convidando você a participar de um projeto de pesquisa do Departamento de Genética da Faculdade de Medicina de Ribeirão Preto - USP, intitulado "Caracterizacão genômica de homem inférteis". O objetivo deste estudo é avaliar a constituição genética do paciente para buscar possíveis causas da infertilidade. Este projeto tem como pesquisadores responsáveis Juliana Dourado Grzesiuk e Carlos Henrique Paiva Grangeiro. Informamos que:

1. Sua participação é espontânea e opcional;

2. Caso você decida não participar, ou desista de participar da pesquisa a qualquer momento, você não perderá nenhum benefício ou tratamento que estiver fazendo neste Hospital;

3. Caso haja alguma dúvida ética, você poderá a qualquer momento entrar em contato com o Comitê de Ética em Pesquisa (CEP) no telefone (16) 36022228 ou no endereço Campus Universitário, Bairro Monte Alegre, CEP 14048900, Ribeirão Preto - SP.

4. Você estará colaborando para aumentar nosso conhecimento sobre as alterações genéticas que podem afetar a fertilidade;

Se você concordar em participar da pesquisa, informamos que:

1. Será necessária a coleta de duas amostras de sangue, de $5 \mathrm{~mL}$ cada, que pode causar algum desconforto no momento da coleta, em alguns casos pode gerar a formação de pequenos hematomas, porém sem nenhum prejuízo para a saúde;

2. Será necessária a coleta de uma amostra de esperma, idêntica a coleta para o exame espermograma, a qual não trará risco para a sua saúde;

3. Os resultados de nosso estudo podem não trazer benefício imediato para seu tratamento;

4. Os resultados demoram algumas semanas ou meses para ficarem prontos e serão adicionados ao seu prontuário médico;

5. O material genético extraído das amostras será utilizado exclusivamente para este fim e sua identidade será mantida em absoluto sigilo.

Eu. tendo sido esclarecido sobre as condições que constam neste documento, declaro que tenho pleno conhecimento dos direitos e das condições que me foram assegurados, a seguir relacionados:

1. A garantia de receber a resposta a qualquer pergunta ou esclarecimento de qualquer dúvida relativa aos procedimentos, riscos, benefícios e de outras situações relacionadas com a pesquisa.

2. A liberdade de retirar meu consentimento e deixar de participar do estudo, sem que isso traga prejuízo à continuidade do atendimento.

3. A segurança de que não serei identificado e que será mantido o caráter confidencial da informação.

4. A garantia de receber uma cópia deste termo de consentimento livre e esclarecido devidamente assinado pelo pesquisador responsável.

Declaro que concordo com as condições que me foram apresentadas e aceito participar do referido projeto.

Ribeirão Preto, de de 20

Assinatura do paciente

Pesquisadores responsáveis:

Juliana Dourado Grzesiuk

(16) 33153081

\section{Carlos Henrique P. Grangeiro CRM: 147428}

(16) 36022598
Profa. Dra. Lúcia Regina Martelli CRM: 40.569 (16)36022598 


\section{APÊNDICE B - Tabela geral dos pacientes com azoospermia (continua)}

\begin{tabular}{|c|c|c|c|c|c|c|c|c|c|c|c|}
\hline \multirow[b]{2}{*}{ Ordem } & \multirow[b]{2}{*}{ Nome } & \multirow[b]{2}{*}{ Idade } & \multirow{2}{*}{$\begin{array}{c}\mathrm{n}^{\circ} \text { da } \\
\text { amostra de } \\
\text { DNA }\end{array}$} & \multirow[b]{2}{*}{$\mathbf{T}$} & \multicolumn{2}{|c|}{ GONADO } & \multirow[b]{2}{*}{ Cariótipo } & \multirow[b]{2}{*}{$\mathbf{A Z F}$} & \multirow[b]{2}{*}{ BX } & \multirow[b]{2}{*}{ DIAGNÓSTICO } & \multirow[b]{2}{*}{ OBS } \\
\hline & & & & & FSH & $\mathrm{LH}$ & & & & & \\
\hline 1 & LCSP & 34 & 152 & 318 & 10,7 & 8,1 & $46, X Y[100]$ & Normal & ACG & $\begin{array}{l}\text { Azoospermia não } \\
\text { Obstrutiva }\end{array}$ & Infertilidade há 6 anos \\
\hline 2 & GAM & 31 & & 257 & 42,4 & 7,9 & $46, X Y[11]$ & Normal & PMCG & $\begin{array}{l}\text { Azoospermia não } \\
\text { Obstrutiva }\end{array}$ & $\begin{array}{c}\text { Hipogonadismo } \\
\text { hipergonadotrófico e } \\
\text { sem exclusão de } \\
\text { mosaicismo }\end{array}$ \\
\hline 3 & RDL & 33 & 155 & 420 & 3,7 & 2,0 & $46, X Y[50]$ & Normal & PMCG & $\begin{array}{l}\text { Azoospermia não } \\
\text { Obstrutiva }\end{array}$ & Infertilidade há 4 anos \\
\hline 4 & THO & 30 & 193 & 411 & 8,3 & 6,7 & $46, X Y[50]$ & Normal & PMCG & $\begin{array}{c}\text { Azoospermia não } \\
\text { Obstrutiva }\end{array}$ & Infertilidade há 5 anos \\
\hline 5 & TAJ & 32 & 159 & 681 & 7,7 & 3,0 & $46, X Y[50]$ & Normal & $\mathrm{ACG}$ & $\begin{array}{l}\text { Azoospermia não } \\
\text { Obstrutiva }\end{array}$ & Infertilidade há 6 anos \\
\hline 6 & GCMS & 29 & 165 & 392 & 8,1 & 5,9 & $46, X Y[50]$ & Normal & $\mathrm{ACG}$ & $\begin{array}{l}\text { Azoospermia não } \\
\text { Obstrutiva }\end{array}$ & Infertilidade há 6 anos \\
\hline 7 & $\mathrm{ADO}$ & 36 & & 624 & 2,9 & 4,6 & $46, X Y, 9 q h+[50]$ & Normal & PMCG & $\begin{array}{l}\text { Azoospermia não } \\
\text { Obstrutiva }\end{array}$ & $\begin{array}{c}\text { Cistos de Epidídimos } \\
\text { + Hidrocele }\end{array}$ \\
\hline 8 & HLCF & 34 & & 535 & 9,2 & 6,2 & $46, X Y[50]$ & $\begin{array}{l}\text { Microdeleção } \\
\text { AZFc }\end{array}$ & $\mathrm{ACG}$ & $\begin{array}{c}\text { Azoospermia não } \\
\text { Obstrutiva }\end{array}$ & Infertilidade há 8 anos \\
\hline 9 & MTV & 32 & & 335 & 9,1 & 2,7 & 46, XY,9qh+ [50] & Normal & $\mathrm{ACG}$ & $\begin{array}{l}\text { Azoospermia não } \\
\text { Obstrutiva }\end{array}$ & Infertilidade há 8 anos \\
\hline 10 & CMLA & 35 & 176 & 383 & 10,1 & 4,2 & $46, X Y[50]$ & Normal & $\mathrm{ACG}$ & $\begin{array}{l}\text { Azoospermia não } \\
\text { Obstrutiva }\end{array}$ & Infertilidade há 7 anos \\
\hline 11 & JARG & 34 & 184 & 445 & 8,7 & 2,7 & $46, X Y[50]$ & Normal & & $\begin{array}{c}\text { Azoospermia não } \\
\text { Obstrutiva }\end{array}$ & Infertilidade há 5 anos \\
\hline 12 & EAPC & 33 & 188 & 395 & 3,2 & 1,0 & $46, X Y[50]$ & Normal & PMCG & $\begin{array}{c}\text { Azoospermia } \\
\text { não Obstrutiva }\end{array}$ & Infertilidade há 4 anos \\
\hline 13 & CFS & 26 & 190 & 320 & 9,4 & 3,7 & $46, X Y[100]$ & Normal & PMCG & $\begin{array}{l}\text { Azoospermia não } \\
\text { Obstrutiva }\end{array}$ & Infertilidade há 4 anos \\
\hline
\end{tabular}


APÊNDICE B - Tabela geral dos pacientes com azoospermia (continuação)

\begin{tabular}{|c|c|c|c|c|c|c|c|c|c|c|c|}
\hline \multirow[b]{2}{*}{ Ordem } & \multirow[b]{2}{*}{ Nome } & \multirow[b]{2}{*}{ Idade } & \multirow{2}{*}{$\begin{array}{c}n^{\circ} \text { da } \\
\text { amostra de } \\
\text { DNA }\end{array}$} & \multirow[b]{2}{*}{$\mathbf{T}$} & \multicolumn{2}{|c|}{ GONADO } & \multirow[b]{2}{*}{ Cariótipo } & \multirow[b]{2}{*}{$\mathbf{A Z F}$} & \multirow[b]{2}{*}{$\mathbf{B X}$} & \multirow[b]{2}{*}{ DIAGNÓSTICO } & \multirow[b]{2}{*}{ OBS } \\
\hline & & & & & FSH & LH & & & & & \\
\hline 14 & FMS & 33 & & 400 & 4,7 & 4,8 & $46, X Y[50]$ & Normal & Normal & $\begin{array}{l}\text { Azoospermia } \\
\text { Obstrutiva }\end{array}$ & $\begin{array}{l}\text { Várias cirurgias do } \\
\text { trato reprodutivo } \\
\text { (orquite) }\end{array}$ \\
\hline 15 & IJS & 35 & & 361 & 4,8 & 2,1 & $46, X Y[50]$ & Normal & Normal & $\begin{array}{l}\text { Azoospermia } \\
\text { Obstrutiva }\end{array}$ & \\
\hline 16 & EJP & 37 & & 820 & 4,0 & 10,0 & $46, X Y[20]$ & Normal & PMCG & $\begin{array}{l}\text { Azoospermia não } \\
\text { Obstrutiva }\end{array}$ & $\begin{array}{c}\text { Insuficiência Parcial a } \\
\text { Andrógenos }\end{array}$ \\
\hline 17 & $\mathrm{RS}$ & 36 & 240 & 300 & 10,5 & 6,5 & $46, X Y[50]$ & Normal & ACG & $\begin{array}{l}\text { Azoospermia não } \\
\text { Obstrutiva }\end{array}$ & Infertilidade há 9 anos \\
\hline 18 & VR & 39 & & 134 & 33 & 12,9 & 47,XXY [20] & Normal & $\mathrm{ACG}$ & $\begin{array}{c}\text { Azoospermia não } \\
\text { Obstrutiva }\end{array}$ & $\begin{array}{l}\text { Síndrome de } \\
\text { Klinefelter }\end{array}$ \\
\hline 19 & CWH & 31 & 247 & 296 & 1,7 & 2,6 & $46, X Y[50]$ & Normal & PMCG & $\begin{array}{l}\text { Azoospermia não } \\
\text { Obstrutiva }\end{array}$ & Infertilidade há 3 anos \\
\hline 20 & ALSM & 39 & 248 & 329 & 9.7 & 6,5 & $46, X Y[100]$ & Normal & & $\begin{array}{l}\text { Azoospermia não } \\
\text { Obstrutiva }\end{array}$ & $\begin{array}{l}\text { Infertilidade há } 12 \\
\text { anos }\end{array}$ \\
\hline 21 & FAB & 34 & 251 & 305 & 11,5 & 5,9 & $46, X Y[50]$ & Normal & PMCG & $\begin{array}{l}\text { Azoospermia não } \\
\text { Obstrutiva }\end{array}$ & Infertilidade há 6 anos \\
\hline 22 & JER & 37 & 254 & 520 & 7,7 & 2,8 & $46, X Y[50]$ & Normal & PMCG & $\begin{array}{l}\text { Azoospermia não } \\
\text { Obstrutiva }\end{array}$ & Infertilidade há 9 anos \\
\hline 23 & ASM & 33 & & 400 & 27,5 & 14,5 & 47,XXY[99]/46,XY[1] & Normal & NA & $\begin{array}{l}\text { Azoospermia não } \\
\text { Obstrutiva }\end{array}$ & $\begin{array}{l}\text { Síndrome de } \\
\text { Klinefelter }\end{array}$ \\
\hline 24 & SMSP & 42 & & 480 & 2,9 & 2,4 & $46, X Y[50]$ & Normal & Normal & $\begin{array}{l}\text { Azoospermia } \\
\text { Obstrutiva }\end{array}$ & \\
\hline 25 & DHS & 24 & 246 & 375 & 4,3 & 5,0 & $46, \mathrm{XY}[50]$ & Normal & & $\begin{array}{l}\text { Azoospermia não } \\
\text { Obstrutiva }\end{array}$ & Infertilidade há 3 anos \\
\hline 26 & LAC & 31 & & 150 & 17,5 & 5,8 & $46, X Y[100]$ & Normal & & $\begin{array}{c}\text { Azoospermia não } \\
\text { Obstrutiva }\end{array}$ & $\begin{array}{c}\text { Hipogonadismo + } \\
\text { Herniorrafia à E + } \\
\text { cistos em epidídimo }\end{array}$ \\
\hline 27 & RAS & 38 & & 340 & 15,4 & 9,9 & $46, X Y[50]$ & Normal & & $\begin{array}{l}\text { Azoospermia não } \\
\text { Obstrutiva }\end{array}$ & $\begin{array}{c}3 \text { Cirurgias } \\
\text { (Orquidopexia) }\end{array}$ \\
\hline
\end{tabular}


APÊNDICE B - Tabela geral dos pacientes com azoospermia (conclusão)

\begin{tabular}{|c|c|c|c|c|c|c|c|c|c|c|c|}
\hline \multirow[b]{2}{*}{ Ordem } & \multirow[b]{2}{*}{ Nome } & \multirow[b]{2}{*}{ Idade } & \multirow{2}{*}{$\begin{array}{c}\mathbf{n}^{\circ} \text { da } \\
\text { amostra de } \\
\text { DNA }\end{array}$} & \multirow[b]{2}{*}{$\mathbf{T}$} & \multicolumn{2}{|c|}{ GONADO } & \multirow[b]{2}{*}{ Cariótipo } & \multirow[b]{2}{*}{$\mathbf{A Z F}$} & \multirow[b]{2}{*}{$\mathbf{B X}$} & \multirow[b]{2}{*}{ DIAGNÓSTICO } & \multirow[b]{2}{*}{ OBS } \\
\hline & & & & & FSH & $\mathrm{LH}$ & & & & & \\
\hline 28 & FJHS & 31 & & 225 & 31 & $\begin{array}{c}] \\
8,9\end{array}$ & 47,XXY [50] & Normal & & $\begin{array}{c}\text { Azoospermia não } \\
\text { obstrutiva }\end{array}$ & $\begin{array}{l}\text { Síndrome de } \\
\text { Klinefelter }\end{array}$ \\
\hline 29 & EAS & 33 & & & & & $46, X Y[50]$ & Normal & & $\begin{array}{l}\text { Azoospermia não } \\
\text { Obstrutiva }\end{array}$ & $\begin{array}{c}\text { Imunossupressão por } \\
\text { Doença de Behçet }\end{array}$ \\
\hline 30 & RAJS & 25 & & 380 & 24 & 14,7 & $46, X Y[50]$ & Normal & & $\begin{array}{c}\text { Azoospermia não } \\
\text { obstrutiva }\end{array}$ & $\begin{array}{c}\text { Doença } \\
\text { multissistêmica em } \\
\text { investigação }\end{array}$ \\
\hline 31 & JSS & 31 & 344 & 350 & 10,1 & 5,5 & $46, X Y[50]$ & Normal & & $\begin{array}{c}\text { Azoospermia não } \\
\text { obstrutiva }\end{array}$ & Infertilidade há 5 anos \\
\hline
\end{tabular}

Gonado = gonadotrofinas; $\mathrm{T}$ = dosagem de testosterona; $\mathrm{BX}=$ resultado da histologia testicular após biópsia 
APÊNDICE C - Tabela dos pacientes com azoospermia não obstrutiva

\begin{tabular}{|c|c|c|c|c|c|c|c|c|c|c|c|}
\hline \multirow[b]{2}{*}{ Ordem } & \multirow[b]{2}{*}{ Sigla } & \multirow[b]{2}{*}{$\begin{array}{l}\text { Idade } \\
\text { (anos) }\end{array}$} & \multirow{2}{*}{$\begin{array}{c}n^{\circ} \\
\text { amostra } \\
\text { de DNA }\end{array}$} & \multirow[b]{2}{*}{$\mathbf{T}$} & \multicolumn{2}{|c|}{ GONADO } & \multirow[b]{2}{*}{ Cariótipo } & \multirow[b]{2}{*}{$\mathbf{A Z F}$} & \multirow[b]{2}{*}{$\mathbf{B X}$} & \multirow[b]{2}{*}{ DIAGNÓSTICO } & \multirow[b]{2}{*}{ OBS } \\
\hline & & & & & FSH & LH & & & & & \\
\hline $\mathbf{A}$ & LCSP & 34 & 152 & 318 & 10,7 & 8,1 & $46, X Y[100]$ & Normal & ACG & $\begin{array}{l}\text { Azoospermia não } \\
\text { Obstrutiva }\end{array}$ & $\begin{array}{c}\text { Infertilidade há } 6 \\
\text { anos }\end{array}$ \\
\hline B & RDL & 33 & 155 & 420 & 3,7 & 2,0 & $46, X Y[50]$ & Normal & PMCG & $\begin{array}{l}\text { Azoospermia não } \\
\text { Obstrutiva }\end{array}$ & $\begin{array}{c}\text { Infertilidade há } 4 \\
\text { anos }\end{array}$ \\
\hline C & TAJ & 32 & 159 & 681 & 7,7 & 3,0 & $46, \mathrm{XY}[50]$ & Normal & ACG & $\begin{array}{l}\text { Azoospermia não } \\
\text { Obstrutiva }\end{array}$ & $\begin{array}{c}\text { Infertilidade há } 6 \\
\text { anos }\end{array}$ \\
\hline D & GCMS & 29 & 165 & 392 & 8,1 & 5,9 & $46, \mathrm{XY}[50]$ & Normal & ACG & $\begin{array}{l}\text { Azoospermia não } \\
\text { Obstrutiva }\end{array}$ & $\begin{array}{c}\text { Infertilidade há } 6 \\
\text { anos }\end{array}$ \\
\hline $\mathbf{E}$ & CMLA & 35 & 176 & 383 & 10,1 & 4,2 & $46, \mathrm{XY}[50]$ & Normal & ACG & $\begin{array}{l}\text { Azoospermia não } \\
\text { Obstrutiva }\end{array}$ & $\begin{array}{c}\text { Infertilidade há } 7 \\
\text { anos }\end{array}$ \\
\hline $\mathbf{F}$ & EAPC & 33 & 188 & 395 & 3,2 & 1,0 & $46, X Y[50]$ & Normal & PMCG & $\begin{array}{c}\text { Azoospermia } \\
\text { não Obstrutiva }\end{array}$ & $\begin{array}{c}\text { Infertilidade há } 4 \\
\text { anos }\end{array}$ \\
\hline $\mathbf{G}$ & THO & 30 & 193 & 411 & 8,3 & 6,7 & $46, \mathrm{XY}[50]$ & Normal & PMCG & $\begin{array}{l}\text { Azoospermia não } \\
\text { Obstrutiva }\end{array}$ & $\begin{array}{c}\text { Infertilidade há } 5 \\
\text { anos }\end{array}$ \\
\hline $\mathbf{H}$ & DHS & 24 & 246 & 375 & 4,3 & 5,0 & $46, X Y[50]$ & Normal & & $\begin{array}{l}\text { Azoospermia não } \\
\text { Obstrutiva }\end{array}$ & $\begin{array}{c}\text { Infertilidade há } 3 \\
\text { anos }\end{array}$ \\
\hline $\mathbf{I}$ & $\mathrm{CWH}$ & 31 & 247 & 296 & 1,7 & 2,6 & $46, \mathrm{XY}[50]$ & Normal & PMCG & $\begin{array}{l}\text { Azoospermia não } \\
\text { Obstrutiva }\end{array}$ & $\begin{array}{c}\text { Infertilidade há } 3 \\
\text { anos }\end{array}$ \\
\hline $\mathbf{J}$ & ALSM & 39 & 248 & 329 & 9.7 & 6,5 & $46, X Y[100]$ & Normal & & $\begin{array}{l}\text { Azoospermia não } \\
\text { Obstrutiva }\end{array}$ & $\begin{array}{c}\text { Infertilidade há } 12 \\
\text { anos }\end{array}$ \\
\hline $\mathbf{K}$ & FAB & 34 & 251 & 305 & 11,5 & 5,9 & 46,XY [50] & Normal & PMCG & $\begin{array}{l}\text { Azoospermia não } \\
\text { Obstrutiva }\end{array}$ & $\begin{array}{c}\text { Infertilidade há } 6 \\
\text { anos }\end{array}$ \\
\hline $\mathbf{L}$ & JER & 37 & 254 & 520 & 7,7 & 2,8 & $46, \mathrm{XY}[50]$ & Normal & PMCG & $\begin{array}{l}\text { Azoospermia não } \\
\text { Obstrutiva }\end{array}$ & $\begin{array}{c}\text { Infertilidade há } 9 \\
\text { anos }\end{array}$ \\
\hline $\mathbf{M}$ & JARG & 34 & 184 & 445 & 8,7 & 2,7 & $46, X Y[50]$ & Normal & & $\begin{array}{l}\text { Azoospermia não } \\
\text { Obstrutiva }\end{array}$ & $\begin{array}{c}\text { Infertilidade há } 5 \\
\text { anos }\end{array}$ \\
\hline $\mathbf{N}$ & CFS & 26 & 190 & 320 & 9,4 & 3,7 & $46, X Y$ [100] & Normal & PMCG & $\begin{array}{l}\text { Azoospermia não } \\
\text { Obstrutiva }\end{array}$ & $\begin{array}{c}\text { Infertilidade há } 4 \\
\text { anos }\end{array}$ \\
\hline $\mathbf{O}$ & $\mathrm{RS}$ & 36 & 240 & 300 & 10,5 & 6,5 & $46, \mathrm{XY}[50]$ & Normal & ACG & $\begin{array}{l}\text { Azoospermia não } \\
\text { Obstrutiva }\end{array}$ & $\begin{array}{c}\text { Infertilidade há } 9 \\
\text { anos }\end{array}$ \\
\hline $\mathbf{P}$ & JSS & 31 & 344 & 350 & 10,1 & 5,5 & $46, \mathrm{XY}[50]$ & Normal & & $\begin{array}{l}\text { Azoospermia não } \\
\text { obstrutiva }\end{array}$ & $\begin{array}{c}\text { Infertilidade há } 5 \\
\text { anos }\end{array}$ \\
\hline
\end{tabular}

Gonado = gonadotrofinas $; \mathrm{T}=$ dosagem de testosterona $; \mathrm{BX}=$ resultado da histologia testicular após biópsia 
APÊNDICE D - Tabela dos indivíduos do grupo controle

\begin{tabular}{|c|c|c|c|c|c|c|c|c|}
\hline \multirow[t]{2}{*}{ Ordem } & \multirow[t]{2}{*}{ Idade } & \multirow[t]{2}{*}{ Espermograma } & \multirow[t]{2}{*}{$\mathbf{T}$} & \multicolumn{2}{|c|}{ GONADO } & \multirow[t]{2}{*}{ Cariótipo } & \multirow[t]{2}{*}{$\mathbf{A Z F}$} & \multirow[t]{2}{*}{ OBS } \\
\hline & & & & FSH & LH & & & \\
\hline C1 & 35 & Normal & 425 & 5,8 & 2,3 & $46, X Y[50]$ & Normal & 3 filhos hígidos \\
\hline $\mathrm{C2}$ & 38 & Normal & 552 & 4,8 & 3,1 & $46, X Y[50]$ & Normal & 2 filhos hígidos \\
\hline C3 & 39 & Normal & 520 & 5,1 & 2,8 & $46, X Y[50]$ & Normal & 2 filhos hígidos \\
\hline $\mathrm{C4}$ & 38 & Normal & 450 & 5,4 & 3,4 & $46, X Y[50]$ & Normal & 3 filhos hígidos \\
\hline C5 & 40 & Normal & 392 & 4,8 & 2,5 & $46, X Y[50]$ & Normal & 2 filhos hígidos \\
\hline C6 & 34 & Normal & 586 & 4,0 & 3,2 & $46, X Y[50]$ & Normal & 2 filhos hígidos \\
\hline
\end{tabular}

Gonado = gonadotrofinas; $\mathrm{T}$ = dosagem de testosterona BX = resultado da histologia testicular após biópsia 
APÊNDICE E - CNVs já descritas na literatura associadas com falência espermatogênica primária (Continua)

\begin{tabular}{|c|c|c|c|c|c|c|}
\hline Cromossomo & Região & Evento & Início & Fim & Genes & Referência \\
\hline 1 & $\mathrm{p} 13.2 \mathrm{p} 13.2$ & Duplicação & $\begin{array}{c}114657 \\
656\end{array}$ & $\begin{array}{c}114814 \\
238\end{array}$ & SYT6 & 2 \\
\hline 1 & p13.3p13.3 & Deleção & $\begin{array}{c}108713 \\
464\end{array}$ & $\begin{array}{c}108900 \\
204\end{array}$ & SLC25A24/NBPF4 & 2 \\
\hline 1 & p21 & Deleção & 104067184 & 104321250 & RNPC3/AMY2B/AMY2A/AMY1A/AMY1C/AMY1B & 6 \\
\hline $\mathbf{1}$ & p23.1 & Duplicação & 156764562 & 156796736 & PRCC/SH2D2A/NTRK1 & 6 \\
\hline 1 & p34.3p34.3 & Duplicação & 36716865 & 36777255 & THRAP3/C1orf113 & 2 \\
\hline $\mathbf{1}$ & $\mathrm{p} 33$ & Deleção & 47580001 & 47680000 & CYP4Z1/LINC00853/PDZK1 & 4 \\
\hline 1 & p36.21 & Duplicação & 15300001 & 15480000 & KAZN/TMEM51 & 4 \\
\hline 2 & p11.2 & Deleção & $89,635,198$ & $89,902,565$ & Sem gene & 1 \\
\hline 2 & p15 & Deleção & 62258290 & 62277149 & COMMD1 & 6 \\
\hline 2 & $\mathrm{p} 25.2 \mathrm{p} 25.2$ & Duplicação & 3062188 & 3325509 & TSSC1 & 2 \\
\hline 2 & $\mathrm{p} 22.2 \mathrm{p} 22.2$ & Deleção & 38085399 & 38180014 & FAM82A1 & 2 \\
\hline 2 & $\mathrm{q} 13$ & Deleção & 110833640 & 110983703 & $M A L L / N P H P 1$ & 6 \\
\hline 2 & q36.1 & Duplicação & 222200001 & 223020000 & EPHA4 & 4 \\
\hline 3 & p11.1 & Deleção & 89476719 & 89499633 & EPHA3 & 1 \\
\hline 3 & p14.1 & Ganho & 65780001 & 66340000 & MAGII/SLAC25A26 & 4 \\
\hline 3 & q24q24 & Duplicação & $\begin{array}{c}146114 \\
122\end{array}$ & $\begin{array}{c}146191 \\
793\end{array}$ & PLSCR2 & 2 \\
\hline 4 & p16.1 & Duplicação & 8235974 & 8261720 & SH3TCl & 1 \\
\hline 4 & q13.2 & Duplicação & 70180001 & 70440000 & $U G T 2 B 4$ & 4 \\
\hline 4 & q13.3 & Deleção & 75019400 & $\begin{array}{c}75117648 \\
10\end{array}$ & MTHFD2L & 6 \\
\hline 4 & $\mathrm{q} 21.1$ & Duplicação & 76504370 & 76521476 & $C D K L 2$ & 6 \\
\hline 5 & $5 \mathrm{p} 13.1$ & Deleção & 40779232 & 40785703 & PRKAAI & 6 \\
\hline 5 & $5 \mathrm{p} 14.3$ & Deleção & 21943466 & 22002677 & $\mathrm{CDH} 12$ & 6 \\
\hline 5 & $\mathrm{q} 11.1$ & Deleção & 49440001 & 49480000 & Sem gene & 4 \\
\hline 5 & $\mathrm{q} 13.2 \mathrm{q} 13.2$ & Duplicação & 69705562 & 70657747 & SERF1A/SERF1B/SMN1/SMN2/NAIP/GTF2H2 & 2 \\
\hline
\end{tabular}


APÊNDICE E - CNVs já descritas na literatura associadas com falência espermatogênica primária (Continuação)

\begin{tabular}{|c|c|c|c|c|c|c|}
\hline Cromossomo & Região & Evento & Início & Fim & Genes & Referência \\
\hline 5 & $\mathrm{q} 13.2 \mathrm{q} 13.2$ & Duplicação & 69732192 & 70386541 & SERF1A/SERF1B/SMN1/SMN2/NAIP/GTF2H2 & 2 \\
\hline 5 & $\mathrm{q} 13.2 \mathrm{q} 13.2$ & Deleção & 70308101 & 70309855 & NAIP & 2 \\
\hline 5 & $\mathrm{q} 13.2 \mathrm{q} 13.2$ & Deleção & 70308101 & 70309855 & NAIP & 2 \\
\hline 5 & $\mathrm{q} 13.2 \mathrm{q} 13.2$ & Duplicação & 70308101 & 70309855 & NAIP & 2 \\
\hline 5 & $\mathrm{q} 23.1$ & Deleção & 117380001 & 117660000 & LINC02147 & 4 \\
\hline 5 & $\mathrm{q} 35.3$ & Deleção & 180400001 & 180440000 & BTNL3 & 4 \\
\hline 6 & p12.1 & Deleção & 52624027 & 52682610 & GSTA2/GSTA1 & 6 \\
\hline 6 & $\mathrm{p} 21.31$ & Duplicação & 35143115 & 35184210 & $A N K S 1 A$ & 1 \\
\hline 6 & p21.32 & Duplicação & 32440001 & 32700000 & $H L A-D R B 1 / H L A-D Q A 1 / H L A-D Q B 1$ & 4 \\
\hline 6 & $\mathrm{q} 26$ & Deleção & 162618199 & 162825032 & PARK2 & 6 \\
\hline 7 & p21.3 & Deleção & 12860001 & 13100000 & Sem gene & 4 \\
\hline 7 & $\mathrm{p} 22.2$ & Duplicação & 3144476 & 3458017 & $S D K 1$ & 6 \\
\hline 7 & q11.22 & Deleção & 66671745 & 66672634 & $T Y W 1$ & 6 \\
\hline 7 & $\mathrm{q} 31.1$ & Deleção & 112180001 & 112360000 & Sem gene & 4 \\
\hline 7 & $\mathrm{q} 35$ & Deleção & 143884029 & 143953472 & FLJ43692/OR2A42/OR2A1 & 6 \\
\hline 8 & p12 & Duplicação & 31500001 & 32040000 & $N R G 1$ & 4 \\
\hline 8 & p22 & Duplicação & 13720001 & 14040000 & $S G C Z$ & 4 \\
\hline 8 & p22 & Deleção & 15403439 & 15409232 & TUSC3 & 6 \\
\hline 8 & $\mathrm{q} 23.1$ & Duplicação & 6828426 & 6837339 & DEFAl & 6 \\
\hline 8 & $\mathrm{q} 24.3$ & Dul/Del & 145061948 & 145093349 & PLEC, MIR661 & 1 \\
\hline 10 & $\mathrm{q} 11.22$ & Duplicação & 46980001 & 47700000 & GPRIN2/NPY4R/ANXA8/FAM35DP/ANTXRLP1 & 4 \\
\hline 10 & $\mathrm{q} 21.1$ & Deleção & 59560001 & 59760000 & Sem gene & 4 \\
\hline 10 & $\mathrm{q} 23.1$ & Deleção & 84138134 & 84171245 & NRG3 & 1 \\
\hline 10 & $\mathrm{q} 23.33$ & Deleção & 96497202 & 96536412 & CYP2C19 & 1 \\
\hline 11 & p11.12 & Deleção & 49240001 & 49980000 & LOC0440040/OR4C13 & 4 \\
\hline 11 & p11.12 & Duplicação & 48800001 & 49380000 & TRIM49B/FOLH1 & 4 \\
\hline 11 & $\mathrm{q} 24.2$ & Duplicação & 124743538 & 124798029 & ROBO3/ROBO4/HEPN1/HEPACAM & 6 \\
\hline
\end{tabular}


APÊNDICE E - CNVs já descritas na literatura associadas com falência espermatogênica primária (Continuação)

\begin{tabular}{|c|c|c|c|c|c|c|}
\hline Cromossomo & Região & Evento & Início & Fim & Genes & Referência \\
\hline 12 & p11.21 & Deleção & 31132516 & 31223665 & DDX11, OVOS2 & 1 \\
\hline 12 & $\mathrm{p} 12.2$ & Duplicação & 21011077 & 21404166 & SLCO1B3/LST-3TM12/SLCO1B1 & 6 \\
\hline 12 & q12 & Deleção & 38580001 & 38740000 & $A L G 10 B$ & 4 \\
\hline 12 & $\mathrm{q} 13.3$ & Duplicação & 55866674 & 55896055 & LRP1, MIR1228 & 1 \\
\hline 12 & q14.1 & Deleção & 60680001 & 60940000 & Sem gene & 4 \\
\hline 12 & q14.2 & Duplicação & 63947732 & 64116568 & DPY19L2 & 6 \\
\hline 12 & $\mathrm{q} 21.32$ & Deleção & 86695679 & 86703030 & MGAT4C & 6 \\
\hline 12 & $\mathrm{q} 23.1$ & Deleção & 98491661 & 98519308 & $A N K S 1 B$ & $1 / 6$ \\
\hline 12 & $\mathrm{q} 24.31 \mathrm{q} 24.31$ & Deleção & 120734605 & 120755841 & SIRT4 & 2 \\
\hline 13 & q11 & Deleção & 19440001 & 19500000 & ANKRD20AOP/LIC00408 & 4 \\
\hline 13 & q12.11 & Duplicação & 20419333 & 20445320 & ZMYM5 & 6 \\
\hline 14 & $\mathrm{q} 11.2$ & Duplicação & 19460001 & 20420000 & $\begin{array}{c}\text { POTEG/BMS1P18/POTEM/OR11H2/OR } \\
4 N 2\end{array}$ & 4 \\
\hline 14 & $\mathrm{q} 11.2$ & Duplicação & 19460001 & 20280000 & $\begin{array}{c}\text { POTEG/BMS1P18/POTEM/OR11H2/OR } \\
4 N 2\end{array}$ & 4 \\
\hline 14 & $\mathrm{q} 11.2$ & Duplicação & 19460001 & 20440000 & $\begin{array}{c}\text { POTEG/BMS1P18/POTEM/OR11H2/OR } \\
4 N 2\end{array}$ & 4 \\
\hline 15 & q11.1 & Duplicação & 20180001 & 22380000 & $\begin{array}{c}\text { CHEK2P2/HERC } 2 P 3 / G O L G A 6 L 6 / P O T E \\
B\end{array}$ & 4 \\
\hline 15 & q14 & Deleção & 34671574 & 34841446 & $\begin{array}{c}\text { GOLGA8A/GOLGA8B/DQ593032/DQ58 } \\
2939 / K\end{array}$ & 6 \\
\hline 15 & $\mathrm{q} 15.3 \mathrm{q} 15.3$ & Duplicação & 43888927 & 43950720 & CKMT1B/STRC/CATSPER2 & 2 \\
\hline 16 & p12.2 & Deleção & 22400001 & 22720000 & RRN3P3/SMG1P1/NPIPB5 & 4 \\
\hline 16 & p12.2 & Duplicação & 55832511 & 55865159 & CES1 & 6 \\
\hline 16 & p13.11 & Deleção & 14968855 & 15115579 & NOMOI/NPIP/PDXDC1 & 6 \\
\hline 16 & $\mathrm{q} 22.1$ & Duplicação & 66942648 & 66967713 & PRMT7, SMPD3 & 2 \\
\hline
\end{tabular}


APÊNDICE E - CNVs já descritas na literatura associadas com falência espermatogênica primária (Continuação)

\begin{tabular}{|c|c|c|c|c|c|c|}
\hline Cromossomo & Região & Evento & Início & Fim & Genes & Referência \\
\hline 16 & $\mathrm{q} 22.3 \mathrm{q} 22.3$ & Deleção & 74375794 & 74455311 & CLEC18B & 2 \\
\hline 17 & p11.2p11.2 & Duplicação & 21370330 & 21453044 & C17orf51 & 2 \\
\hline 17 & p11.2p11.2 & Deleção & 21370330 & 21453044 & C17orf51 & 2 \\
\hline 17 & $\mathrm{q} 12$ & Deleção & 30624580 & 30787596 & SLFN11, SLFN12, SLFN13 & 1 \\
\hline 18 & $\mathrm{q} 21.1$ & Deleção & 52212057 & 52306572 & C18orf 26 & 6 \\
\hline 18 & $\mathrm{q} 21.31$ & Deleção & 55931229 & 55936547 & $N E D D 4 L$ & 6 \\
\hline 18 & $\mathrm{q} 23$ & Dup/Del & 75746093 & 75779459 & $K C N G 2, P Q L C 1$ & 1 \\
\hline 21 & $\mathrm{q} 22.3$ & Duplicação & 44700001 & 45240000 & LIC00322/SIK1/LINC00319/RRP1B & 4 \\
\hline 22 & q11.21 & Duplicação & 18894835 & 19010508 & DGCR6/PRODH & \\
\hline 22 & q13.33 & Deleção & 50296855 & 503013692 & $A L G 12$ & \\
\hline $\mathbf{X}$ & p11.22 & Duplicação & 52657689 & 52978139 & $\begin{array}{c}\text { SSX7, SSX2, SPANXN5, XAGE5, XAGE3, } \\
\text { FAM156A, FAM156B }\end{array}$ & 1 \\
\hline $\mathbf{X}$ & p11.22 & Deleção & $52,065,798$ & $52,069,943$ & Sem gene & 3 \\
\hline $\mathbf{X}$ & p11.22 & Duplicação & 52842080 & 52909890 & SPANXN5, XAGE5, XAGE3 & 1 \\
\hline $\mathbf{X}$ & p11.23 & Deleção & $47,766,391$ & $47,847,516$ & ZNF630 & 3 \\
\hline $\mathbf{X}$ & p11.3 & Duplicação & $44,067,590$ & 44084085 & EFHC2 & 1 \\
\hline $\mathbf{X}$ & p11.3 & Duplicação & $47,766,391$ & $47,847,516$ & ZNF630 & 3 \\
\hline $\mathbf{X}$ & p11.4 & Duplicação & 38376283 & 38513841 & TSPAN7 & 1 \\
\hline $\mathbf{X}$ & $\mathrm{p} 21.1$ & Duplicação & $37,168,387$ & $37,256,960$ & PRRG1 & $3 / 5$ \\
\hline $\mathbf{X}$ & $\mathrm{p} 21.1$ & Duplicação & $37,242,364$ & $37,251,969$ & Sem gene & 3 \\
\hline $\mathbf{X}$ & $\mathrm{p} 21.3$ & Deleção & $25,274,024$ & $25,280,712$ & Sem gene & 3 \\
\hline $\mathbf{X}$ & $\mathrm{p} 21.3$ & Deleção & $25,568,263$ & 25583583 & Sem gene & 1 \\
\hline $\mathbf{X}$ & $\mathrm{p} 21.3$ & Deleção & $26,891,769$ & $26,959,101$ & Sem gene & 3 \\
\hline $\mathbf{X}$ & p21.3 & Duplicação & 28162190 & 28214748 & Sem gene & 1 \\
\hline $\mathbf{X}$ & $\mathrm{p} 21.3$ & Duplicação & $27,277,529$ & $27,337,933$ & Sem gene & 3 \\
\hline $\mathbf{X}$ & p22.11 & Deleção & $22,969,648$ & $22,993,997$ & Sem gene & 3 \\
\hline $\mathbf{X}$ & $\mathrm{p} 22.2$ & Duplicação & $11,104,518$ & $11,706,614$ & ARHGAP6 AMELX MSL3 & $3 / 5$ \\
\hline
\end{tabular}


APÊNDICE E - CNVs já descritas na literatura associadas com falência espermatogênica primária (Continuação)

\begin{tabular}{|c|c|c|c|c|c|c|}
\hline Cromossomo & Região & Evento & Início & Fim & Genes & Referência \\
\hline $\mathbf{X}$ & $\mathrm{p} 22.2$ & Duplicação & 16688233 & 16707403 & SYAPl & 1 \\
\hline $\mathbf{X}$ & p22.31 & Deleção & $6,594,834$ & $6,626,533$ & Sem gene & 3 \\
\hline $\mathbf{X}$ & p22.31 & Deleção & $6,756,310$ & $6,838,310$ & Sem gene & 3 \\
\hline $\mathbf{X}$ & p22.31 & Duplicação & $7,002,649$ & $7,247,676$ & STS HDHDIA & 3 \\
\hline $\mathbf{X}$ & p22.33 & Duplicação & 1,544 & 226,372 & $P L C X D 1$ GTPBP6 PPP $2 R 3 B$ & $3 / 5$ \\
\hline $\mathbf{X}$ & p22.33 & Duplicação & 302,644 & 462,740 & Sem gene & $3 / 5$ \\
\hline $\mathbf{X}$ & p22.33 & Duplicação & $1,347,599$ & $1,387,328$ & $C S F 2 R A$ & $3 / 5$ \\
\hline $\mathbf{X}$ & p22.33 & Deleção & $2,711,073$ & 2814530 & $X G, G Y G 2$ & 1 \\
\hline $\mathbf{X}$ & $\mathrm{q} 11.1$ & Duplicação & 64806000 & 64854709 & $M S N$ & 1 \\
\hline $\mathbf{X}$ & q11.2 & Duplicação & 65385501 & 65413711 & $H E P H$ & 1 \\
\hline $\mathbf{X}$ & $\mathrm{q} 21$ & Duplicação & $80,225,590$ & $80,230,870$ & Sem gene & 5 \\
\hline $\mathbf{X}$ & $\mathrm{q} 22.1$ & Deleção & $101,803,578$ & $101,848,935$ & $A R M C X 5-G P R A S P 2$ & 3 \\
\hline $\mathbf{X}$ & $\mathrm{q} 22.1$ & Duplicação & 102134796 & 102496321 & $\begin{array}{c}\text { BEX1, NXF3, BEX4, TCEAL8, TCEAL5, } \\
\text { BEX2, TCEAL7 }\end{array}$ & 1 \\
\hline $\mathbf{X}$ & $\mathrm{q} 22.2$ & Duplicação & 103066101 & 103190187 & $T M S B 15 B, H 2 B F X P, H 2 B F W T, H 2 B F M$ & 1 \\
\hline $\mathbf{X}$ & $\mathrm{q} 22.3$ & Duplicação & 110238448 & 110260226 & $P A K 3$ & 1 \\
\hline $\mathbf{X}$ & $\mathrm{q} 22.3-\mathrm{q} 23$ & Duplicação & 110226892 & 110965127 & $P A K 3, C A P N 6, D C X, A L G 13, T R P C 5$ & 1 \\
\hline $\mathbf{X}$ & $\mathrm{q} 23$ & Deleção & 111598447 & 111621531 & Sem gene & 1 \\
\hline $\mathbf{X}$ & $\mathrm{q} 24$ & Deleção & $118,281,024$ & $118,325,874$ & Sem gene & 3 \\
\hline $\mathbf{X}$ & q24 & Duplicação & $118,780,844$ & $118,798,128$ & Sem gene & 1 \\
\hline $\mathbf{X}$ & $\mathrm{q} 25$ & Duplicação & 122920543 & 123009115 & $S T A G 2$ & 1 \\
\hline $\mathbf{X}$ & $\mathrm{q} 25$ & Deleção & 123911267 & 124039708 & ODZ1 & 1 \\
\hline $\mathbf{X}$ & $\mathrm{q} 25$ & Deleção & $124,632,886$ & $124,718,959$ & Sem gene & 3 \\
\hline $\mathbf{X}$ & $\mathrm{q} 25$ & Deleção & $124,929,673$ & $125,117,699$ & Sem gene & 3 \\
\hline $\mathbf{X}$ & $\mathrm{q} 26.3$ & Duplicação & 134120502 & 134157976 & CXorf48 & 1 \\
\hline $\mathbf{X}$ & $\mathrm{q} 26.3$ & Duplicação & 134600709 & 134628136 & Sem gene & 3 \\
\hline
\end{tabular}


APÊNDICE E - CNVs já descritas na literatura associadas com falência espermatogênica primária (Conclusão)

\begin{tabular}{ccccccc}
\hline Cromossomo & Região & Evento & Início & Fim & Genes & Referência \\
\hline $\mathbf{X}$ & $\mathrm{q} 26.3$ & Duplicação & 134778328 & 134910134 & CT45-1/CT45-2/CT45-4/CT45-3 \\
\hline $\mathbf{X}$ & $\mathrm{q} 27.1$ & Duplicação & 139706586 & 139904507 & MIR320D2 \\
$\mathbf{X}$ & $\mathrm{q} 27.2$ & Deleção & $140,773,893$ & $140,778,561$ & MAGEC3 \\
\hline $\mathbf{X}$ & $\mathrm{q} 27.3$ & Deleção & $145,030,566$ & $145,037,917$ & Sem gene \\
\hline $\mathbf{X}$ & $\mathrm{q} 28$ & Deleção & $148,456,474$ & $148,461,889$ & Sem gene \\
\hline $\mathbf{X}$ & $\mathrm{q} 28$ & Delecão & $154,044,877$ & 154079019 & Sem gene \\
\hline $\mathbf{X}$ & $\mathrm{q} 28$ & Deleção & $154,586,913$ & $154,877,901$ & SPRY3 VAMP7 \\
\hline $\mathbf{Y}$ & $\mathrm{p} 11.2$ & Duplicação & 7348864 & 7491480 & Sem gene \\
\hline $\mathbf{Y}$ & $\mathrm{q} 11.223$ & Duplicação & 21964794 & 22058959 & RBMY2EP $(A Z F b / b c)$ \\
\hline $\mathbf{q}$ & $\mathrm{q} 11.23$ & Duplicação & 26870161 & 27073218 & Sem gene \\
\hline
\end{tabular}

Autores: 1 (TÜTTELMANN et al., 2011/ Agilent ${ }^{\circledR}$ 244K e 400K, hg18), 2 (STOUFFS et al., 2012/Agilent ${ }^{\circledR}$ 244K, hg19); 3 (KRAUSZ et al., 2012/ Agilent ${ }^{\circledR}$ 8x60K customizado, hg19); 4 (DONG et al., 2015/ não descreve a plataforma, hg19); 5 (CHIANESE et al., 2014/ Agilent ${ }^{\circledR}$ $8 \times 60$ K customizado, hg19) e 6 (STOUFFS et al., 2015/ Agilent $^{\circledR} 244 \mathrm{~K}$, hg19) 
APÊNDICE F - CNVs raras e não descritas, após análise no DGV (Continua)

\section{Deleções}

\begin{tabular}{|c|c|c|c|c|c|c|}
\hline & Cromossomo & Localização & $\begin{array}{c}\text { Sub- } \\
\text { banda }\end{array}$ & $\begin{array}{c}\text { Tamanho } \\
(\mathbf{k b})\end{array}$ & Avaliação & Genes \\
\hline \multirow{2}{*}{$\mathbf{A}$} & 2 & $172,948,765-172,952,539$ & q31.1 & 3,7 & $\mathrm{CNV}$ rara & $D L X 1$ \\
\hline & 3 & $50,436,577-50,663,730$ & $\begin{array}{l}\mathrm{p} 21.31- \\
\mathrm{p} 21.2\end{array}$ & 227 & $\mathrm{CNV}$ rara & $\begin{array}{c}\text { CACNA2D2, C3orf18, HEMK1, CISH, } \\
\text { MAPKAPK3 }\end{array}$ \\
\hline $\mathbf{J}$ & 2 & $172,948,765-172,952,539$ & q31.1 & 3,7 & CNV rara & $D L X 1$ \\
\hline
\end{tabular}

\section{Duplicações}

\begin{tabular}{ccccccc}
\hline & 2 & $45,171,872-45,179,881$ & $\mathrm{p} 21$ & 8 & CNV rara & SIX3 \\
\cline { 2 - 6 } & 2 & $176,989,208-176,991,241$ & $\mathrm{q} 31.1$ & 2 & CNV rara & HOXD9 \\
\hline
\end{tabular}


APÊNDICE F - CNVs raras e não descritas, após análise no DGV (Continuação)

\begin{tabular}{|c|c|c|c|c|c|c|}
\hline \multirow{6}{*}{$\mathbf{C 3}$} & 2 & $172,948,765-172,952,539$ & $\mathrm{q} 31.1$ & 3,7 & $\mathrm{CNV}$ rara & $D L X 1$ \\
\hline & 3 & $46,619,743-46,621,498$ & $\mathrm{p} 21.31$ & 1,7 & $\mathrm{CNV}$ rara & $T D G F 1$ \\
\hline & 19 & $3,555,792-4,126,127$ & $\mathrm{p} 13.3$ & 570 & $\mathrm{CNV}$ rara & $\begin{array}{c}\text { MFSD12, HMG20B, GIPC3, TBXA2R, } \\
\text { CACTIN-AS1, CACTIN, PIP5K1C, TJP3, } \\
\text { APBA3, MRPL54, RAX2, MATK, ZFR2, } \\
\text { MIR1268A, ATCAY, NMRK2, MIR637, DAPK3, } \\
\text { EEF2, SNORD37, PIAS4, ZBTB7A, MAP2K2 }\end{array}$ \\
\hline & 21 & $47,615,666-47,636,871$ & $\mathrm{q} 22.3$ & 21 & $\mathrm{CNV}$ rara & $L S S$ \\
\hline & $X$ & $48,740,187-48,757,706$ & p11.23 & 17 & CNV rara & $T I M M 17 B, P Q B P 1$ \\
\hline & & $53,458,836-53,460,122$ & p11.22 & 1,2 & $\mathrm{CNV}$ rara & HSD17B10 \\
\hline \multirow{5}{*}{$\mathrm{C} 4$} & 2 & $45,171,731-45,179,881$ & $\mathrm{p} 21$ & 8 & $\mathrm{CNV}$ rara & SIX3 \\
\hline & 7 & $1,165,490-1,810,613$ & $\mathrm{p} 22.3$ & 645 & $\mathrm{CNV}$ rara & $\begin{array}{c}\text { C7orf50, ZFAND2A, LOC101927021, UNCX, } \\
\text { MICALL2, INTS1, MAFK, TMEM184A, } \\
\text { PSMG3, PSMG3-AS1, TFAMP1, ELFN1, } \\
\text { ELFN1-AS1 }\end{array}$ \\
\hline & 11 & $2,019,598-2,157,060$ & $\mathrm{p} 15.5$ & 137 & $\mathrm{CNV}$ rara & $H 19, M I R 483, I G F 2, I N S-I G F 2$ \\
\hline & 14 & $101,291,902-101,294,412$ & $\mathrm{q} 32.2$ & 2,5 & $\mathrm{CNV}$ rara & MEG3 \\
\hline & $\mathrm{X}$ & $152,643,148-152,956,961$ & q28 & 313 & $\mathrm{CNV}$ rara & $\begin{array}{c}\text { ZFP92, TREX2, HAUS7, BGN, ATP2B3, } \\
\text { FAM58A, LOC105373383, DUSP9, PNCK, } \\
\text { SLC6A8 }\end{array}$ \\
\hline
\end{tabular}


APÊNDICE F - CNVs raras e não descritas, após análise no DGV (Continuação)

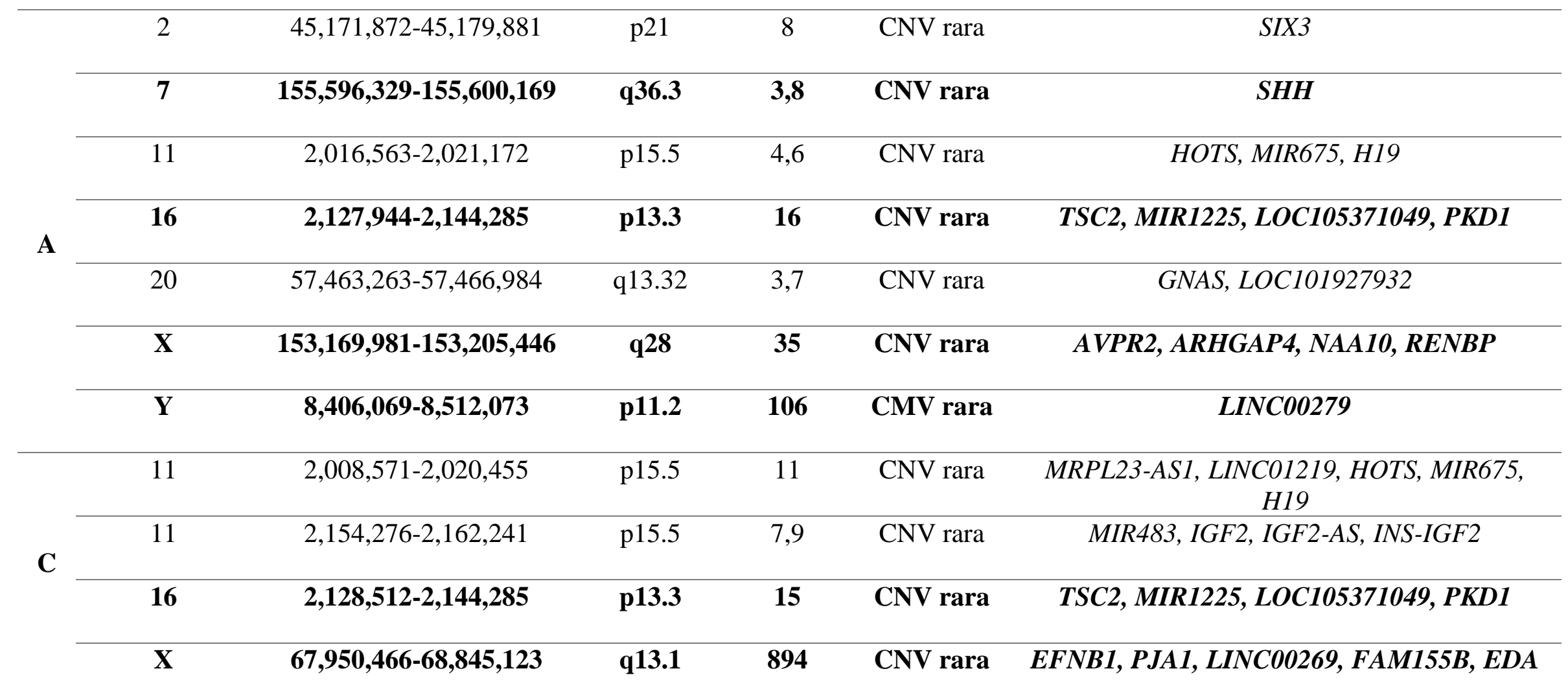


APÊNDICE F - CNVs raras e não descritas, após análise no DGV (Continuação)

\begin{tabular}{|c|c|c|c|c|c|c|}
\hline D & 3 & $46,620,075-46,621,247$ & p21.31 & 1,1 & CNV rara & TDGF1 \\
\hline \multirow{6}{*}{$\mathbf{E}$} & 2 & $172,948,765-172,952,539$ & q31.1 & 3,7 & CNV rara & $D L X 1$ \\
\hline & 3 & $46,619,743-46,621,247$ & $\mathrm{p} 21.31$ & 1,5 & $\mathrm{CNV}$ rara & $T D G F 1$ \\
\hline & 16 & $85,549,343-85,667,640$ & q24.1 & 118 & CNV rara & GSE1 \\
\hline & 19 & $4,502,351-4,641,905$ & p13.3 & 139 & CNV rara & PLIN4, PLIN5, LRG1, SEMA6B, TNFAIP8L1 \\
\hline & $\mathbf{X}$ & 77,158,835-77,160,060 & q21.1 & 1,2 & $\begin{array}{c}\text { CNV } \\
\text { nunca } \\
\text { descrita }\end{array}$ & COX7B \\
\hline & $\mathbf{X}$ & 118,986,572-119,007,025 & $\mathbf{q 2 4}$ & 20 & CNV rara & UPF3B, RNF113A, NDUFA1 \\
\hline \multirow{5}{*}{$\mathbf{G}$} & 2 & $172,948,765-172,952,539$ & q31.1 & 3,7 & CNV rara & $D L X 1$ \\
\hline & 3 & $46,619,743-46,621,498$ & $\mathrm{p} 21.31$ & 1,7 & $\mathrm{CNV}$ rara & $T D G F 1$ \\
\hline & 11 & $2,534,486-2,567,683$ & p15.5 & 33 & $\mathrm{CNV}$ rara & $K C N Q 1$ \\
\hline & 17 & $48,241,425-48,273,531$ & q21.33 & 32 & CNV rara & SGCA, HILS1, COL1A1 \\
\hline & 21 & $47,615,666-47,635,259$ & $\mathrm{q} 22.3$ & 19 & $\mathrm{CNV}$ rara & $L S S$ \\
\hline
\end{tabular}


APÊNDICE F - CNVs raras e não descritas, após análise no DGV (Conclusão)

\begin{tabular}{|c|c|c|c|c|c|c|}
\hline & 2 & 172,950,861-172,952,539 & q31.1 & 1,6 & CNV rara & DLX1 \\
\hline \multirow[t]{2}{*}{$\mathbf{H}$} & 17 & $48,255,995-48,270,899$ & q21.33 & 14 & CNV rara & COL1A1 \\
\hline & 19 & $4,502,351-4,641,905$ & p13.3 & 139 & CNV rara & PLIN4, PLIN5, LRG1, SEMA6B, TNFAIP8L1 \\
\hline \multirow[t]{3}{*}{$\mathbf{I}$} & 11 & $2,151,117-2,162,241$ & $\mathrm{p} 15.5$ & 11 & CNV rara & MIR483, IGF2, IGF2-AS, INS-IGF2 \\
\hline & 2 & $45,171,872-45,179,881$ & $\mathrm{p} 21$ & 8 & CNV rara & SIX3 \\
\hline & 11 & $2,017,399-2,021,172$ & $\mathrm{p} 15.5$ & 3,7 & CNV rara & HOTS, MIR675, H19 \\
\hline \multirow[t]{5}{*}{$\mathbf{J}$} & 20 & $57,463,263-57,466,984$ & q13.32 & 3,7 & CNV rara & GNAS, LOC101927932 \\
\hline & & $65,760,836-65,939,751$ & q12 & 178 & CNV rara & UPRT, ZDHHC15 \\
\hline & & $153,169,981-153,205,446$ & q28 & 35 & CNV rara & AVPR2, ARHGAP4, NAA10, RENBP \\
\hline & 2 & $45,171,872-45,179,878$ & $\mathrm{p} 21$ & 8 & CNV rara & SIX3 \\
\hline & 11 & $2,016,665-2,024,224$ & $\mathrm{p} 15.5$ & 7,5 & CNV rara & HOTS, MIR675, H19 \\
\hline \multirow[t]{2}{*}{$\mathbf{L}$} & 14 & $101,291,902-101,294,412$ & $\mathrm{q} 32.2$ & 2,5 & CNV rara & MEG3 \\
\hline & 20 & $57,463,263-57,466,984$ & q13.32 & 3,7 & CNV rara & GNAS, LOC101927932 \\
\hline $\mathbf{N}$ & 2 & $45,172,062-45,179,881$ & $\mathrm{p} 21$ & 7,8 & CNV rara & SIX3 \\
\hline
\end{tabular}




\title{
APÊNDICE G - Manuscrito a ser submetido
}

\section{MANUSCRIPT}

\section{New rare copy number variations in male nonobstructive azoospermia}

\section{GRANGEIRO, C. H. P. ${ }^{1,2}$; GRZESIUK, J. D. ${ }^{1}$; JOAQUIM, T. M. ${ }^{1}$; OLIVEIRA- GENNARO, F. G. ${ }^{1}$; HUBER, J. ${ }^{2}$; SQUIRE, J. A. ${ }^{3}$; MARTELLI, L. ${ }^{1,2}$}

${ }^{1}$ Department of Genetics, Ribeirão Preto Medical School, University of São Paulo, São Paulo, Brazil. Av. Bandeirantes, 3900. Ribeirão Preto - SP, Brazil -14049-900.

${ }^{2}$ Department of Medical Genetics, Clinical Hospital of Ribeirão Preto Medical School, University of São Paulo, São Paulo, Brazil. Av. Bandeirantes, 3900. Ribeirão Preto - SP, Brazil -14049-900.

${ }^{3}$ Department of Pathology and Legal Medicine, Ribeirão Preto Medicine School, University of São Paulo, São Paulo, Brazil. Av. Bandeirantes, 3900. Ribeirão Preto - SP, Brazil -14049-900.

Corresponding author: Lucia Martelli, Department of Genetics, Ribeirão Preto Medical School, University of São Paulo, São Paulo, Brazil. Av. Bandeirantes, 3900. Ribeirão Preto - SP, Brazil -14049900. email: 1rmartel@fmrp.usp.br

\begin{abstract}
Male infertility is a complex phenotype associated with an interaction of different factors. The genetic factors involved may range from point mutations, microdeletions on the $\mathrm{Y}$ chromosome to chromosomal changes such as Klinefelter syndrome. Even after detailed clinical-laboratory evaluation, the etiology remais unknown in approximately half of the patients characterizing idiopathic male infertility. In this group are observed the patients with nonobstructive azoospermia (NOA) due to primary spermatogenic failure and it is likely that a large proportion of this cases are caused by still unknown genetic factors. In order to better understand the potential genomic changes involved with idiopathic male infertility, sixteen patients with NOA and 6 controls were investigated by the genomic hybridization technique (aCGH), using the Agilent ${ }^{\circledR} 4 \times 180 \mathrm{CGH}+$ SNP platform. Data analyses were performed by Nexus 8.0 software. Four gains (7q36.3, 17q21.33, Xq21.1 and Yp11.2) and 2 losses $(2 \mathrm{q} 31.1$ and 3p21.1-21.31) with their respective genes $(\mathrm{SHH}$, COL1A1, COX7B, LINC00279, DLX1 and CACNA2D2) were considered relevant and contributing to a better understanding of the complex and poorly explored mechanisms that result in nonobstructive azoospermia.
\end{abstract}

Keywords: Male infertility. Nonobstructive azoospermia (NOA). Comparative genomic hybridization. Copy number variation (CNV)

\section{Introduction}

Infertility is clinically defined as the inability to conceive a child after one or more years of regular intercourse without the use of contraceptive methods (1). It affects 10-15\% of 
couples in Western countries and the male factor accounts for $50 \%$ of the cases $(2,3)$. Male infertility is a complex disorder in wich the genetic factors, such as chromosomal abnormalities, Y chromosome microdeletions and point mutations, are responsible for $30 \%$ of the cases (4). Even after detailed clinical-laboratory assessment, the etiology remais unknown in approximately half of the patients characterizing idiopathic male infertility. In this group are observed the patients with nonobstructive azoospermia (NOA) or severe oligozoospermia due to primary spermatogenic failure (5). More recently, genomic research has explored regions ranging in size from kilobases $(\mathrm{kb})$ to megabases $(\mathrm{Mb})$ that are present in variable copy numbers $(\mathrm{CNV})$. This submicroscopic chromosomal duplications or deletions have been shown to be an important source of genetic diversity with remarkable diferences between individuals and to play a role in complex diseases such as mental retardation, schizophrenia and cancer $(6,7)$. In recent years, evidence has emerged indicating that differences in the number or distribution of CNVs may be an important determinant of male infertility by a variety of pathogenetic mechanisms, including dosage sensitivity of a gene within the CNV; gene interruption or gene fusion at the breakpoint junctions; deletion of a regulatory element; or unmasking of a recessive mutation, affecting the activity of essencial genes for spermatogenesis (8 13). With the aim of contributing to the understanding of the role of these variants on male fertility, we performed high-resolution array in a group of well-characterised idiopathic infertile men with nonobstructive azoospermia.

\section{Materials and Methods}

Ethical issues

The study was approved by the local Ethics Committee of the Clinical Hospital of Ribeirão Preto Medical School and all individuals gave their informed consent after genetic counseling.

\section{Subjects}

We investigated 16 nonconsanguineous Brazilian patients with idiopathic nonobstructive azoospermia and 6 normozoospermic men. All participants were selected by the Division of Urology of the Clinical Hospital of Ribeirão Preto Medical School. The control group consisted of healthy men, aged 25 to 35 years, who had at least 2 children and in whom vasectomy was indicated. All subjects were selected on the basis of a comprehensive 
andrological examination including medical history, semen and hormone analysis, based on the 2010 guideline of the World Health Organization, karyotype and Y chromosome microdeletion screening. All men with known clinical (e.g. maldescended testes, varicocele, infections) and laboratory causes of infertility were excluded.

Methods

Peripheral blood samples were collected in all individuals for karyotype and DNA extraction. Cytogenetics analyses used standard protocols and 50 metaphases were analyzed by G-banding. DNA extraction was performed using the MasterPure $^{\mathrm{TM}}$ Complete DNA and RNA Purification Kit - Epicentre (US). Y-chromosome microdeletion were investigated through multiplex polymerase chain reaction (PCR) including the sequence-tagged site primers sY84, sY86 for AZFa, sY127, sY134 for $\mathrm{AZFb}$, and sY254, sY255 for AZFc, according to a protocol published by European Academy of Andrology (EAA) and European Molecular Genetics Quality Network (EMQN) (14).

\section{Array-CGH}

The SNP array analyses were performed using the Agilent 4x180 SurePrint G3 CGH+SNP platform (Agilent Technologies, CA, USA) following the manufacturer's protocol. This array comprised 110,712 oligonucleotides (CNV) and 59,647 single nucleotide polymorphisms probes (SNP) with a median probe spacing of $\sim 13 \mathrm{~kb}$. All CNVs data were called with Nexus 8.0 software (BioDiscovery, El Segundo, California) with the Fast Adaptive States Segmentation Technique (FASST2) with a significance threshold of 5.0e-6 and a maximum spacing of adjacent probes of $10,000 \mathrm{~Kb}$. We used three probes and $>1 \mathrm{~kb}$ as a minimum cutoff for $\mathrm{CNVs}$ detection. A log-ratio probe threshold of 0.5 was set to define regions with one-copy gain; 1.14 for high gains (gains of two or more copies); -0.5 for one-copy losses; and -1.1 for homozygous losses. The results were interpreted with coordinates of genomic alterations based on the National Center for Biotechnology Information (NCBI) Human Genome Build 37 (h19). We referred to the Database of Genomic Variants (http://projects.tcag.ca/variation/) to exclude benign CNVs, and the UCSC genome browser (https://www.genome.ucsc.edu/) to determine genes affected by each $\mathrm{CNV}$. 
Statistical analysis

Clinical variables such as age and gonadotrophin dosage were compared between the control and nonobstructive azoospermic patients by the Mann-Whitney test. The comparisons between the variables total number of losses and gains, between the two groups, used the Kruskal-Wallis test. All statistical analyzes were performed using software R v3.4.2. Significant differences were observed when $p<0.05$.

\section{Results}

Clinical data

Comparison of clinical data on patients and controls groups showed that infertile individuals had lower ages and reduced testosterone levels when compared to the control group ( $\mathrm{p}=0.006$ and $\mathrm{p}=0.019$, respectively), whereas gonadotrophin values (FSH and LH) did not present a statistically significant difference when compared between the two groups ( $\mathrm{p}=0.42$ and $\mathrm{p}=0.15$, respectively) (Table 1$)$.

CNVs analysis

In total, $158 \mathrm{CNVs}$ were detected in both groups, of which 41 in the control group and 117 in the infertile group. There were 35 gains and 6 losses in control group and 88 gains and 29 losses in cases group. CNV size ranged from $1.1 \mathrm{~kb}$ to $2.7 \mathrm{Mb}$. No significant differences were observed between to either the number or the size of the genomic changes and the mean number of individuals in both groups (Figure 1). Analysis of Database of Genomic Variants indicated that 143 of these variants had previously been reported to occur in healthy individuals, and as such these variants were excluded from subsequente analysis. Among fifteen new and rare CNVs, only 4 gains (7q36.3, 17q21.33, $\mathrm{Xq} 21.1$ and $\mathrm{Yp} 11.2)$ and 2 losses (2q31.1 and 3p21.1-21.31) with their respective genes (SHH, COL1A1, COX7B, LINC00279, DLX1 and CACNA2D2) were considered relevant for the nonobstructive azoospermia phenotype (Figure 2; Table 2). 
Table 1 - Comparison of clinical parameters between study groups. The $\mathrm{p}$ value was obtained through the Mann-Whitney test

\begin{tabular}{lccc}
\hline & Case & Control & $\mathrm{p}$ \\
\cline { 2 - 4 } Age (years) (mean; median) & $33 ; 33$ & $38 ; 38$ & 0.006 \\
Testosterone (unit) (mean; median) & $392 ; 383$ & $500 ; 520$ & 0.019 \\
FSH (unit) (mean; median) & $12.9 ; 8.3$ & $4.8 ; 4.8$ & 0.42 \\
LH (unit) (mean; median) & $4.4 ; 4.2$ & $3.0 ; 3.1$ & 0.15 \\
\hline
\end{tabular}

Figure 1 - Distribution of number of CNVs by mean of individual in both groups

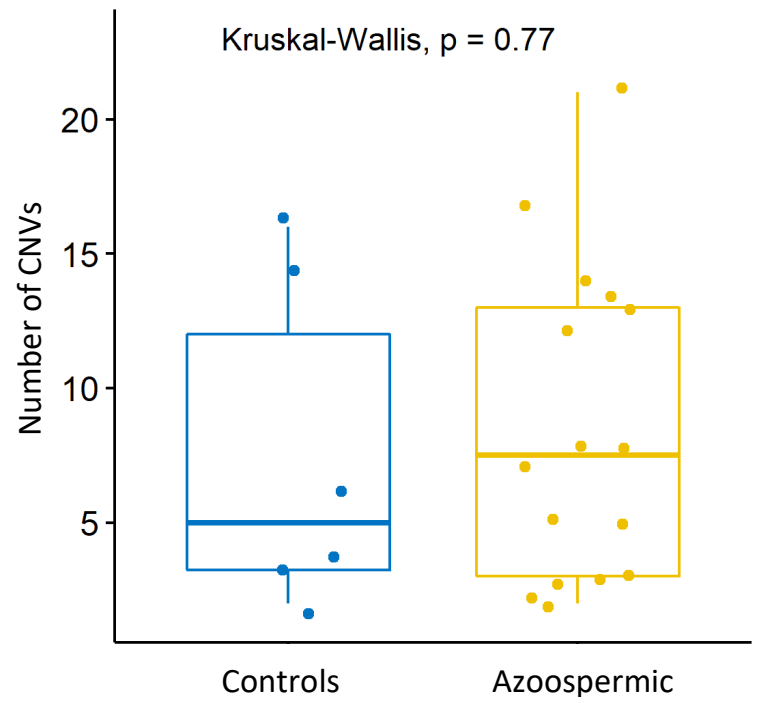

No significant difference $(p=0.77)$ was observed in the distribution of the total number of copy number variants in both groups 
Figure 2 - Flow chart of CNV analysis obtained through Agilent's single nucleotide polymorphism array and data analyses performed by Nexus 8.0 software

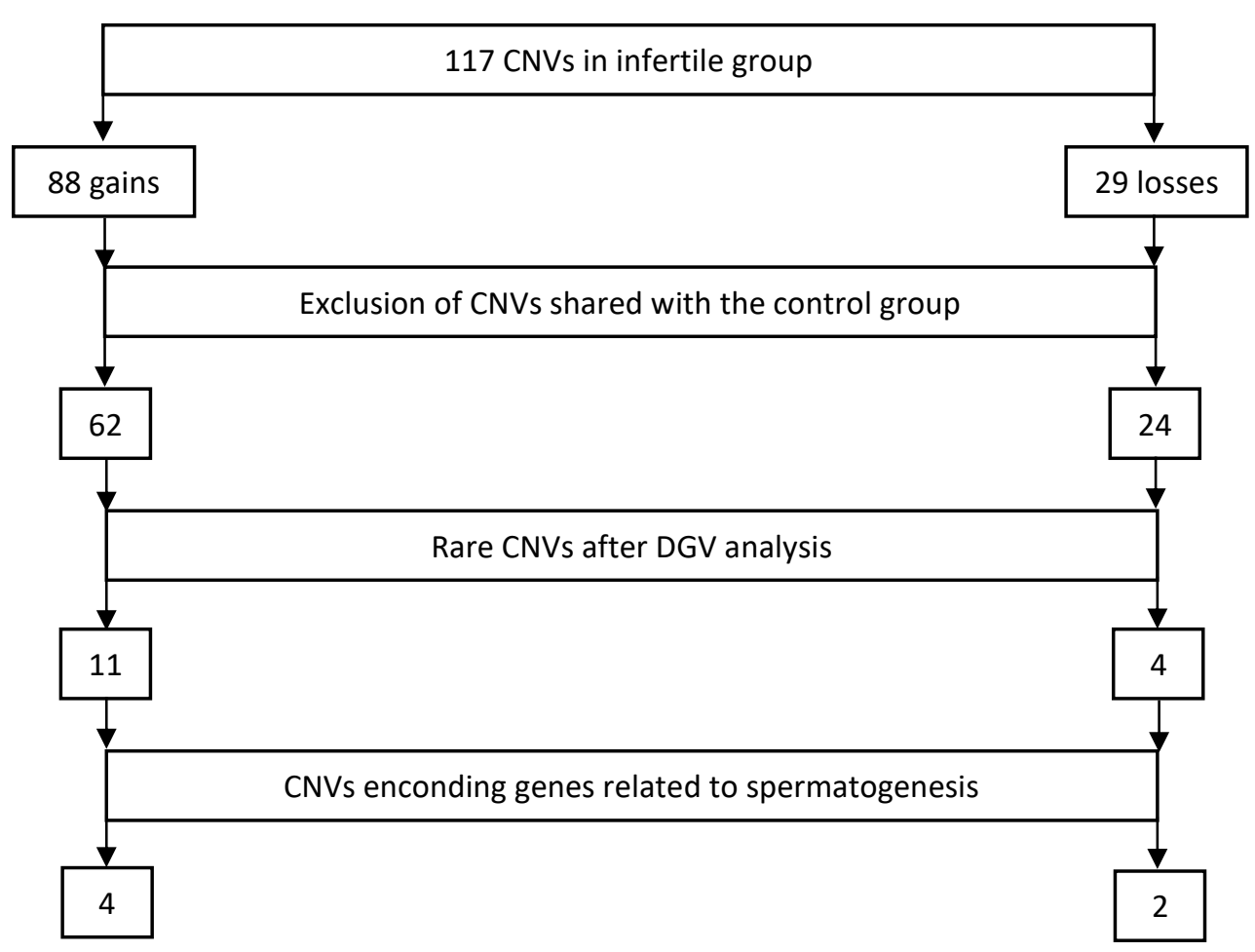


Table 2- New and rare CNVs detected in patients with nonobstructive azoospermia

\begin{tabular}{|c|c|c|c|c|c|}
\hline Chromosome & Genomic position & Cytoband & Lenght & Event & Genes \\
\hline 2 & $172,948,765-172,952,539$ & $\mathrm{q} 31.1$ & $3,7 \mathrm{~kb}$ & Homozygous Copy Loss & CACNA2D2, \\
\hline 3 & $50,436,577-50,663,730$ & $\mathrm{p} 21.1-21.31$ & $227 \mathrm{~kb}$ & Homozygous Copy Loss & $\begin{array}{c}\text { C3orf18, HEMK1, } \\
\text { CISH, MAPKAPK3 }\end{array}$ \\
\hline 7 & $155,596,329-155,600,169$ & $\mathrm{q} 36.3$ & $3,8 \mathrm{~kb}$ & High Copy Gain & SHH \\
\hline 17 & $48,241,425-48,273,531$ & $\mathrm{q} 21.33$ & $32 \mathrm{~kb}$ & High Copy Gain & SGCA, HILS1, \\
\hline $\mathrm{X}$ & $77,158,835-77,160,060$ & $\mathrm{q} 21.1$ & $1,2 \mathrm{~kb}$ & High Copy Gain & COX7B \\
\hline $\mathrm{Y}$ & $8,406,069-8,512,073$ & $\mathrm{p} 11.2$ & $106 \mathrm{~kb}$ & CN Gain & LINC00279 \\
\hline
\end{tabular}




\section{Discussion}

We use high resolution SNP array to identify candidate CNV regions to a group of 16 idiopathic infertile men with primary spermatogenic failure resulting in nonobstructive azoospermia. We identified 4 gains and 2 losses with their respective six candidate genes (DLX1, CACNA2D2, SHH, COL1A1, COX7B and LINC00279) associated with male infertility.

In $2 \mathrm{q} 31.1$ we observed the homozygous copy loss with $3,7 \mathrm{~kb}$ shared by two individuals of infertile group. The loss of this region was also described by Grzesiuk and colleagues in 2016 in three patients with severe oligozoospermia, but the gene content was differed in both studies. In the present study, the loss included exons 1 and 2 of the DLXI gene while in the previous work the deletion involved DLX2 gene. These genes encode members of a homeobox transcription factor gene family similiar to the Drosophila distalless gene and controls the craniofacial morphogenesis, differentiation and survival of inhibitory neurons of the forebrain and retinal bipolar neurons. Mice model observed that DLX family genes regulate the migration and development of neurons secreting the gonadotrophin regulating hormone (15). However, alteration in this pathway results in hypogonadotrophic hypogonadism compromising fertility, but not primary spermatogenic failure.

In 3p21.1-21.31 we detected a homozygous copy loss of 227kb including the genes CACNA2D2, C3orf18, HEMK1, CISH and MAPKAPK3. The CACNA2D2 is most probably gene related to the male infertility phenotype since it encodes a structural protein $(\alpha 2 \delta 2$ subunit of the calcium channel dependent on voltage) that is more sensitive to haploinsufficiency than the other genes encoding enzymes. Deregulation of the CACNA2D2 pathway alters mechanisms such as, cell proliferation, apoptosis and angiogenesis, which may influence sperm production (16).

The gain detected in 7q36.3 involved the SHH gene. This gene encodes an essential protein that is instrumental in patterning the early embryo. It has been implicated as the key inductive signal in patterning of the ventral neural tube, the anterior-posterior limb axis, and the ventral somites. The role of the hedgehog signaling pathway in the sexual differentiation of mammals encompasses cell fate and an epithelial-mesenchyme interaction, which is a critical process in remodeling and tissue differentiation, that occurs in the testicular tissue, in addition to cellular homeostasis. In mice, it was observed that the deregulation of this 
pathway could compromise the formation and maintenance of the seminiferous tubules, besides compromising spermatogenesis by altering the interaction of the interstitium (Leydig cells) with the germ cells (17).

The gain detected in subband q21.33 of chromosome 17 was shared by two individuals with nonobstructive azoospermia. Grzesiuk and colleagues in 2016 also detected gains in this same subband in 2 patients with moderate oligozoospermia. In both studies, the intersection region included only the COL1A1 gene. This gene encodes components of the subunits of type 1 collagen and different types of mutations lead to different clinical phenotypes such as osteogenesis imperfecta, Ehlers-Danlos syndrome and Caffey's disease. In mice, it was observed that the expression of colla1 occurs exclusively in spermatogonia, since to the extent that these cells follow their normal course of differentiation, they lose the marking for this protein, in addition, the reduction of the expression of this protein stimulates the differentiation of the spermatogonia. In this way, the overexpression of this protein could change the differentiation of germ cells $(18,19)$.

Grzesiuk and colleagues, in 2016, described two patients with severe oligozoospermia who presented the same gain in Xq21.1 involving the $C O X 7 B$ gene. This gene is responsible for encoding a member of cytochrome oxidase $\mathrm{c}$, the terminal component of the respiratory chain. In dairy sires it was observed that increased transcription of a COX family member $(C O X 7 C)$ in the testicular tissue showed negative correlation with fertility. It was hypothesized that this increase in expression was associated with dysfunction of mitochondrial function during the spermatogenesis stages (20).

The last gain was detected in the p11.2 subband of Y chromosome. Tüttelmann and colleagues in 2011 described a gain involving this subband in a patient with spermatogenic failure, but this CNV differed in size, genomic position and gene content. In the present work this gain involved a long non-coding RNA (LINC00279) with exclusive testicular expression and its function is still little known. Like miRNAs, which have spatial and temporal expression, the mRNAs also have a differentially ordered expression, depending on the cell type and the stage of cell division. This pattern of expression seems to regulate several stages of meiotic division and spermiogenesis. Unlike protein regulation, in which protein-coding genes are silenced during the pachytene phase by a process called meiotic sex chromosome inactivation (MSCI), the expression of lncRNAs is greater at this specific stage of cell division $(21,22)$. 


\section{Conclusion}

In conclusion, we observed differences in the number as in the size of CNVs between the sample and control groups, but these differences were not statistically significant. Six new rare CNVs were detected in this study, reinforcing the understanding that male infertility due to primary spermatogenic failure should be analyzed in the context of a complex phenotype in which some genetic variants may alter molecular and cellular mechanisms that have not yet been studied, which compromise a spermatogenesis.

\section{Acknowledgements}

The authors gratefully acknowledge the participation of the patients and control subjects. We also acknowledge Professor Carlos Augusto Fernandes Molina for clinicalurological evaluation of patients and Professor Geraldo Aleixo Passos Júnior and his postdoctoral student, Amanda Freira Assis Riccardi, for their support in array-CGH technique. This work has been supported by the Coordination for the Improvement of Higher Education Personnel (CAPES, Brazil) and the Foundation of Support to Teaching, Research and Assistance of Clinics Hospital, Ribeirao Preto Medical School, University of São Paulo (FAEPA-HCFMRP).

\section{Conflict of interest statement}

The authors have no conflicts of interest to declare.

\section{References}

1. BISHT, S.; FAIQ, M.; TOLAHUNASE, M.; DADA, R.; Oxidative stress and male infertility. Nature Reviews Urology, v. 14, n. 8, p. 470-485. 2017. doi:10.1038/nrurol.2017.69

2. AgArwal, A.; Mulgund, A.; HAMAdA, A.; CHYATte, M. R. A unique view on male infertility around the globe. Reproductive Biology and Endocrinology, v. 37, n. 13, p. 1-9, 2015

3. FRÜHMESSER, A.; VOGT, P. H.; ZIMMER, J.; WITSCH-BAUMGARTNER, M.; FAUTH, C.; ZSCHOCKE, J.; PINGERRA, G-M.; KOTZOT, D.; Single nucleotide polymorphism array analysis in men with idiopathic azoospermia or 
oligoasthenozoospermia syndrome. Fertility and Sterility, v.100, n. 1, p. 81-87, 2013. doi:10.1016/j.fertnstert.2013.03.016

4. CARRELL, D. T.; ASTON, K. I.; OLIVA, R.; EMERY, B. R.; DE JONGE, C. J. The "omics" of human male infertility: integrating big data in a systems biology approach. Cell and Tissue Research, v. 363, n. 1, p. 295 - 312, 2016. doi:10.1007/s00441-015-2320-7

5. COCUZZA, M.; ALVARENGA, C.; PAGANI, R. The epidemiology and etiology of azoospermia, Clinics, v. 68, p. 15-26, 2013. Suplemento 1. doi:10.6061/clinics/2013(Sup01)03

6. ASTON, K. I. Genetic susceptibility to male infertility: news from genome-wide association studies. Andrology, v. 2, n. 3, p. 315-321, 2014. doi:10.1111/j.20472927.2014. 00188.x

7. MIKHAIL, F. M. Copy number variations and human genetic disease. Current Opinion Pediatrics, v. 26, n. 6, p. 646-652, 2014 . doi: 10.1097/MOP.0000000000000142.

8. EGGERS, S.; DeBOER, K. D.; VAN DEN BERGEN, J.; GORDON, L.; WHITE, S. J.; JAMSAI, D.; McLACHLAN, R.; SINCLAIR, A. H.; O’BRAYAN, M. K. Copy number variation associated with meiotic arrest in idiopathic male infertility. Fertility and Sterility, v. 103, n. 1, p. 214-219. 2015. doi:10.1016/j.fertnstert.2014.09.030

9. TÜTTELMANN, F.; SIMONI, M.; KLIESCH, S.; LEDIG, S.; DWORNICZAK, B.; WIEACKER, P.; ROPKE, A. Copy number variation in patients with severe oligozoospermia and Sertoli-cell only syndrome. Plos One, v.6, n. 4, p. e19426, 2011. doi: 10.1371/journal.pone.0019426

10. STOUFFS, K.; VANDERMAELEN, D.; MASSART, A.; MENTEN, B.; VERGULT, S. TOURNAYE, H. LISSENS, W. Array comparative genomic hybridization in male infertility. Human Reproduction, v. 27, n. 3, p. 921-929, 2012. doi:10.1093/humrep/der440

11. KRAUSZ, C.; GIACHINI, C.; LO GIACCO, D.; DAGUIN, F.; CHIANESE, C; ARS, E.; RUIZ CASTANE, E.; FORTI, G.; ROSSI, E. High resolution X chromosome specific array-CGH detects new CNVs in infertile males. Plos One, v. 7, n. 10, p. e44887, 2012. doi:10.1371/journal.pone.0044887

12. HALDER, A.; KUMAR, P.; JAIN, M.; LYER, V. K. Copy number variations in testicular maturation arrest. Andrology, v. 5, n. 3, p. 460-472, 2017. doi:10.1111/andr.12330

13. HAREL, T.; LUPSKI, J. R.; Genomic disorders 20 years on - mechanisms for clinical manifestations. Clinical Genetics, p. 1-11, 2017. doi: 10.1111/cge.13146 IN PRESS 
14. KRAUSZ, C.; HOEFSLOOT, L.; SIMONI, M.; TÜTTELMANN, F. Academy European, of Andrology, European Molecular Genetics Quality Network EAA/EMQN best practice guidelines for molecular diagnosis of Y-chromosomal microdeletions: state-of-the-art 2013. Andrology, v. 2, n. 1, p. 5-19, 2014. doi:10.1111/j.2047-2927.2013.00173.x

15. HOFFMANN, H. M.; TRANG, C.; GONG, P.; KIMURA, I.; PANDOLFI, E. C.; MELLON, P. L. Deletion of Vaxl from Gonadotropin-Releasing Hormone (GnRH) Neurons Abolishes GnRH Expression and Leads to Hypogonadism and Infertility. The Journal of Neuroscience, v. 36, n. 12, p. 3506-3518, 2016. doi: 10.1523/JNEUROSCI.2723-15.2016

16. WARNIER, M.; ROUDBARAKI, M.; DEROUICHE, S.; DELCOURT, P.; BOKHOBZA, A.; PREVARSKAYA, N.; MARIOT, P. CACNA2D2 promotes tumorigenesis by stimulating cell proliferation and angiogenesis. Oncogene, v. 34, p. 5383-5394, 2015. doi: 10.1038/onc.2014.467

17. FRANCO, H. L.; YAO, H. H-C.; Sex and hedgehog: roles of genes in the hedgehog signaling pathway in mammalian sexual differentiation. Chromosome Research, v. 20 , n. 1, p. 247-258, 2012. doi: 10.1007/s 10577-011-9254-z

18. CHEN, S-H.; LI, D; XU, C.; Downregulation of Col1a1 induces differentiation in mouse spermatogonia. Asian Journal of Andrology, v. 14, p. 842-849, 2012. doi:10.1038/aja.2012.66

19. HE, Z.; FENG, L.; ZHANG, X.; GENG, Y.; PARODI, D. A.; SUAREZ-QUIAN, C.; DYN, M. Expression of Col1a1, Col1a2 and procollagen I in germ cells of immature and adult mouse testis. Reproduction Research, v. 130, p. 333-341, 2005. doi:10.1530/rep.1.00694

20. CARD, C. J.; KRIEGER, K. E.; KAPROTH, M.; SARTINI, B. L. Oligo-dT selected spermatozoal transcript profiles differ among higher and lower fertility dairy sires. Animal Reproduction Science, v. 177, p. 105-123, 2017. doi: 10.1016/j.anireprosci.2016.12.011.

21. WICHMAN, L.; SOMASUNDARAM, S.; BREIDEL, C.; VALEIRO, D. M.; McCARREY, J. R.; HODGES, C. A.; KHALIL, A. M. Dynamic expression of long non-coding RNAs reveals their potential roles in spermatogenesis and fertility. Biology of Reproduction, v. 97, n. 2, p. 313-323, 2017. doi: 10.1093/biolre/iox084. In PRESS

22. GRZESIUK, J. D. Genomic investigation of infertile patients with oligozoospermia [thesis]. Ribeirão Preto: University of Sao Paulo, São Paulo, 2016. 


\section{$\mathcal{A} \mathcal{N} \mathcal{X} X O S$}

"Qualquer curva de qualquer destino que desfaça o curso de qualquer certeza"

Arnaldo Antunes 


\title{
11. ANEXOS
}

\section{ANEXO A - Termo de aceite do projeto de pesquisa}

\author{
HOSPITAL DAS CLINICAS DA FACULDADE DE MEDICINA
} DE RIBEIRÃO PRETO DA UNIVERSIDADE DE SABO PAULO

Ribeirăo Preto, 25 de setembro de 2013

Oficio $n^{\circ} 3537 / 2013$

CEPIFC

\section{Prezadas Senhoras,}

O trabalhe intitulado "CARACTERIAC̣Ão GENÔMTCA DE PACIENTES OLICOZOOSPÉRMICOS" - versảo 3, de 17/09/2013, foi analisado pelo Comité de Ética em Pesquisa, em sua $374^{a}$ Reuniâo Ordinária realizada em 23/09/2013 e enquadrado na categoria: APROVADO, bem como o Termo de Consentimento Livre e Esclarecido - versāo 3, de 17/09/2013, de acordo com o Processo HCRP n" 8715/2013.

De acordo com Carta Circular $n^{*}$ 003/2011/CONEP/CNS, datada de $21 / 03 / 201 \mathrm{~J}$, o sujeito de pesquisa ou seu representante, quando for o caso, detwena nubricar todas as folhas do Termo de Consentimento Livre e Esclarecido - TCLE - apondo sua assinatura na ultima do referido Termo; a pesquisador responsavel devera da mesma forma, nubricar todas as folhas do Termo de Consentimento Live e Esclarecido - TCLE - apondo saa assinatura na altima página do referido Termo.

Este Comite segue integralmente a Conferencia Internacional de Hamonizacao de Boas Práticas Cinicas (RGH-GCP), bem como a Resolucao n" $466 / 12$ CNS/MS.

Lembramas que deivem ser apresentados a este CEP o Relatóno Parcial e o Relatóno Final da pesquisa.

Atenciosamente.

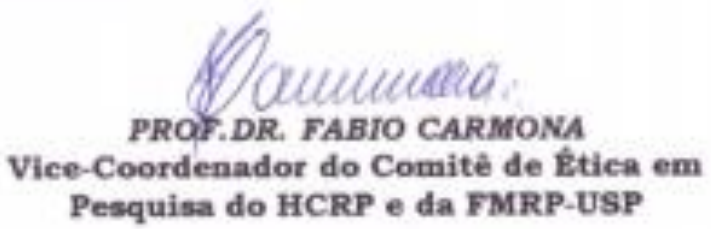

llustrissimas Senhoras

JULIANA DOURADO GRZESTUK

PROF ${ }^{a}$, DR* $^{*}$. LÚCIA REGINA MARTELLI

Depto. de Genética da FMRP.USP 